\title{
NIOSH HAZARD REVIEW
}

\section{Health Effects of Occupational Exposure to Respirable Crystalline Silica}

DEPARTMENT OF HEALTH AND HUMAN SERVICES

Centers for Disease Control and Prevention

National Institute for Occupational Safety and Health

April 2002 


\title{
Ordering Information
}

To receive documents or more information about occupational safety and health topics, contact the National Institute for Occupational Safety and Health (NIOSH) at

\author{
NIOSH-Publications Dissemination \\ 4676 Columbia Parkway \\ Cincinnati, OH 45226-1998
}

Telephone: 1-800-35-NIOSH (1-800-356-4674)

Fax: 1-513-533-8573

E-mail: pubstaft@cdc.gov

or visit the NIOSH Web site at www.cdc.gov/niosh

This document is in the public domain and may be freely copied or reprinted.

Disclaimer: Mention of any company or product does not constitute endorsement by NIOSH.

DHHS (NIOSH) Publication No. 2002-129 


\section{Foreword}

Cilicosis is the disease most associated with crystalline silica exposure; it is incurable but

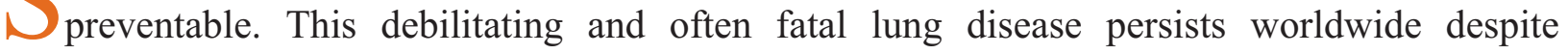
long-standing knowledge of its cause and methods for controlling it.

This Hazard Review, Health Effects of Occupational Exposure to Respirable Crystalline Silica, describes published studies and literature on the health effects of occupational exposure to respirable crystalline silica among workers in the United States and many other countries. The review indicates a significant risk of chronic silicosis for workers exposed to respirable crystalline silica over a working lifetime at the current Occupational Safety and Health Administration (OSHA) permissible exposure limit (PEL), the Mine Safety and Health Administration (MSHA) PEL, or the National Institute for Occupational Safety and Health (NIOSH) recommended exposure limit (REL). In addition to the risk of silicosis, epidemiologic studies indicate that workers exposed to respirable crystalline silica have an increased risk of developing lung cancer, pulmonary tuberculosis, and airways diseases. The latest scientific information also indicates possible associations of occupational exposure to silica dust with various other adverse health effects.

Until improved sampling and analytical methods are developed for respirable crystalline silica, NIOSH will continue to recommend an exposure limit of $0.05 \mathrm{mg} / \mathrm{m}^{3}$ as a time-weighted average (TWA) for up to a 10-hr workday during a 40-hr workweek. NIOSH also recommends substituting less hazardous materials for crystalline silica when feasible, using appropriate respiratory protection when source controls cannot keep exposures below the REL, and making medical examinations available to exposed workers.

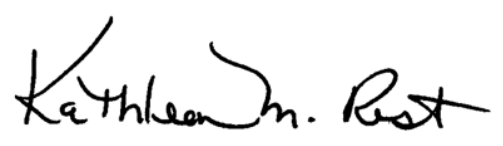

Kathleen M. Rest, Ph.D., M.P.A.

Acting Director, National Institute for

Occupational Safety and Health

Centers for Disease Control and Prevention 


\section{Abstract}

$\mathrm{O}$ ccupational exposures to respirable crystalline silica are associated with the development of silicosis, lung cancer, pulmonary tuberculosis, and airways diseases. These exposures may also be related to the development of autoimmune disorders, chronic renal disease, and other adverse health effects. Recent epidemiologic studies demonstrate that workers have a significant risk of developing chronic silicosis when they are exposed to respirable crystalline silica over a working lifetime at the current Occupational Safety and Health Administration (OSHA) permissible exposure limit (PEL), the Mine Safety and Health Administration (MSHA) PEL, or the National Institute for Occupational Safety and Health (NIOSH) recommended exposure limit (REL).

This NIOSH Hazard Review (1) examines the health risks and diseases associated with occupational exposures to respirable crystalline silica, (2) discusses important findings of recent epidemiologic studies, (3) provides the reader with sources of more comprehensive information about health effects and experimental studies, (4) describes current sampling and analytical methods and their limitations for assessing occupational exposures to respirable crystalline silica, and (5) suggests many areas for further research.

Current sampling and analytical methods used to evaluate occupational exposure to respirable crystalline silica do not meet the accuracy criterion needed to quantify exposures at concentrations below the NIOSH REL of $0.05 \mathrm{mg} / \mathrm{m}^{3}$ as a time-weighted average (TWA) for up to a 10-hr workday during a 40-hr workweek. Until improved sampling and analytical methods are developed for respirable crystalline silica, NIOSH will continue to recommend an exposure limit of $0.05 \mathrm{mg} / \mathrm{m}^{3}$ to reduce the risk of developing silicosis, lung cancer, and other adverse health effects. NIOSH also recommends minimizing the risk of illness that remains for workers exposed at the REL by substituting less hazardous materials for crystalline silica when feasible, by using appropriate respiratory protection when source controls cannot keep exposures below the NIOSH REL, and by making medical examinations available to exposed workers. 


\section{Executive Summary}

$\mathrm{O}$ ccupational exposures to respirable crystalline silica occur in a variety of industries and occupations because of its extremely common natural occurrence and the wide uses of materials and products that contain it. At least 1.7 million U.S. workers are potentially exposed to respirable crystalline silica [NIOSH 1991], and many are exposed to concentrations that exceed limits defined by current regulations and standards.

Silicosis, usually a nodular pulmonary fibrosis, is the disease most associated with exposure to respirable crystalline silica. Although the reported mortality associated with silicosis has declined over the past several decades, many silicosis-associated deaths still occur (nearly 300 deaths were reported each year during the period 1992-1995) [NIOSH 1996a; Althouse 1998]. In addition, the number of silicosisassociated deaths among persons aged 15 to 44 has not declined substantially [CDC 1998a,b]. An unknown number of workers also continue to die from silica-related diseases such as pulmonary tuberculosis (TB), lung cancer, and scleroderma. The number of cases of silicosis and silica-related diseases in the United States today is unknown.

Symptoms of acute silicosis, another form of silicosis, may develop shortly after exposure to high concentrations of respirable crystalline silica. Epidemiologic studies focus on chronic silicosis, which develops years after exposure to relatively low concentrations of respirable crystalline silica. Epidemiologic studies have found that chronic silicosis may develop or progress even after occupational exposure has ceased [Hessel et al. 1988; Hnizdo and Sluis-Cremer 1993; Hnizdo and Murray 1998; Ng et al. 1987; Kreiss and Zhen 1996; Miller et al. 1998]. Over a 40- or 45-year working lifetime, workers have a significant chance (at least 1 in 100) of developing radiographic silicosis when exposed to respirable crystalline silica at the Occupational Safety and Health Administration (OSHA) permissible exposure limit (PEL), the Mine Safety and Health Administration (MSHA) PEL, or the National Institute for Occupational Safety and Health (NIOSH) recommended exposure limit (REL).

Silicosis may be complicated by severe mycobacterial or fungal infections. About half of these are caused by Mycobacterium tuberculosis and result in TB. Epidemiologic studies have firmly established that silicosis is a risk factor for developing TB.

The carcinogenicity of crystalline silica in humans has been strongly debated in the scientific community. In 1996, the International Agency for Research on Cancer (IARC) reviewed the published experimental and epidemiologic studies of cancer in animals and workers exposed to respirable crystalline silica and concluded that there was "sufficient evidence in humans for the carcinogenicity of inhaled crystalline silica in the form of quartz or cristobalite from occupational sources" [IARC 1997]. In the same year, directors of the American Thoracic Society (ATS) adopted an official statement that described the adverse health effects of exposure to crystalline silica, including lung cancer [ATS 1997]. The ATS found that "the available data support the conclusion that silicosis produces increased risk

\footnotetext{
*See appendix for the OSHA and MSHA PELs. The NIOSH REL is $0.05 \mathrm{mg} / \mathrm{m}^{3}$ as a time-weighted average (TWA) for up to a 10-hr workday during a 40-hr workweek.
} 
for bronchogenic carcinoma." However, the ATS noted that less information was available for lung cancer risks among silicotics who had never smoked and for silica-exposed workers who did not have silicosis. They also stated that it was "less clear" whether silica exposure was associated with lung cancer in the absence of silicosis. NIOSH has reviewed the studies considered by IARC and ATS, and NIOSH concurs with the conclusions of IARC [1997] and the ATS [1997]. These conclusions agree with NIOSH testimony to OSHA, in which NIOSH recommended that crystalline silica be considered a potential occupational carcinogen [54 Fed. Reg.* 2521 (1989)]. Further research is needed to determine the exposure-response relationship between lung cancer in nonsmokers and occupational silica dust exposure and to determine why lung cancer risks appear to be higher in workers with silicosis. The cellular mechanisms for development of lung cancer after crystalline silica exposure have been explored in many experimental studies and are not yet fully understood.

Statistically significant excesses of mortality from stomach or gastric cancer have been reported in various occupational groups exposed to crystalline silica. However, no conclusion about an association has been reached because most studies did not adjust for the effects of confounding factors or assess an exposure-response relationship for crystalline silica. The same problem exists for the infrequent reports of statistically significant numbers of excess deaths or cases of other nonlung cancers in silica-exposed workers.

Occupational exposure to respirable crystalline silica is associated with chronic obstructive pulmonary disease, including bronchitis and emphysema. The results of some epidemiologic studies suggest that these diseases may be less

*Federal Register. See Fed. Reg. in references. frequent or absent in nonsmokers. Exposure to respirable crystalline silica is not associated with asthma.

Significant increases in mortality from nonmalignant respiratory disease (a broad category that can include silicosis and other pneumoconioses, chronic bronchitis, emphysema, asthma, and other related respiratory conditions) have been reported for silica-exposed workers [Checkoway et al. 1997, 1993; Chen et al. 1992; Cherry et al. 1998; Brown et al. 1986; Costello and Graham 1988; Costello et al. 1995; Costello 1983; Steenland and Brown 1995b; Steenland and Beaumont 1986; Thomas and Stewart 1987; Thomas 1990] and silicotics [Goldsmith et al. 1995; Brown et al. 1997; Rosenman et al. 1995].

Many case reports have been published about autoimmune diseases or autoimmune-related diseases in workers exposed to crystalline silica or workers with silicosis. In addition, several recent epidemiologic studies reported statistically significant numbers of excess cases or deaths from known autoimmune diseases or immunologic disorders (scleroderma, systemic lupus erythematosus, rheumatoid arthritis, sarcoidosis), chronic renal disease, and subclinical renal changes. The pathogenesis of autoimmune and renal diseases in silicaexposed workers is not clear.

Various other health effects (such as hepatic or hepatosplenic silicosis, extrapulmonary deposition of silica particles, liver granulomas, hepatic porphyria, cutaneous silica granulomas, pulmonary alveolar proteinosis, podoconiosis, and dental abrasion) have been reported in studies of silica-exposed workers, but these effects have not been studied in depth with epidemiologic methods.

This Hazard Review also provides an abbreviated review of experimental research studies conducted to identify the molecular mechanisms responsible for the development of 
silicosis and lung cancer. The results of these studies indicate the need for (1) additional long-term carcinogenesis studies in animals to determine dose-response relationships and (2) in vivo and in vitro studies to develop effective cellular and molecular models of carcinogenesis.

Although a large body of published literature describes the health effects of crystalline silica, some areas require further research. Many uncertainties exist, including (1) mechanisms and the influence of particle characteristics on development of disease; (2) toxicity and pathogenicity of nonquartz crystalline silica, silica substitutes, and dust mixtures; (3) translocation of particles from the lung; and (4) dose/ exposure-response relationships in animals and in humans. In addition, further information is needed about (1) methods for reducing dust exposures in a wide variety of industries and the feasibility of implementing such methods, (2) methods for effectively communicating to workers the dangers of inhaling silica dust and the importance of using appropriate control technologies and other protective measures, and (3) exposure sampling and analytical methods that will allow quantification of crystalline silica at low airborne concentrations (currently these techniques do not meet the accuracy criterion needed to quantify exposures at concentrations below the NIOSH REL).

Until improved sampling and analytical methods are developed for respirable crystalline silica, NIOSH will continue to recommend an exposure limit of $0.05 \mathrm{mg} / \mathrm{m}^{3}$ to reduce the risk of developing silicosis, lung cancer, and other adverse health effects. NIOSH also recommends minimizing the risk of illness that remains for workers exposed at the REL by substituting less hazardous materials for crystalline silica when feasible, by using appropriate respiratory protection when source controls cannot keep exposures below the NIOSH REL, and by making medical examinations available to exposed workers. 


\section{Contents}

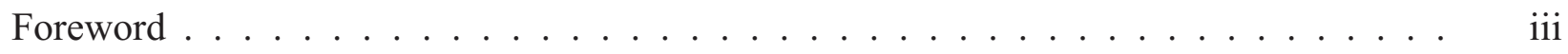

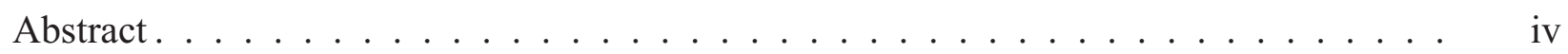

Executive Summary. . . . . . . . . . . . . . . . . . . . $\quad$ v

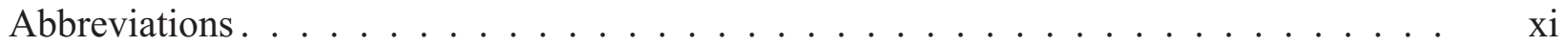

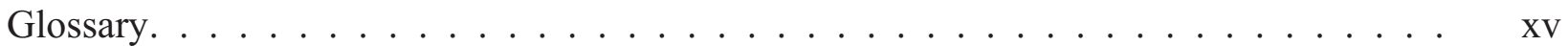

Acknowledgments ........................... xvii

1 Introduction ...................... 1

1.1 Definition of Crystalline Silica . . . . . . . . . . . . . . . . . . . 1

1.2 Current Health Issues . . . . . . . . . . . . . . . . . . . . . . . 1

1.3 History of NIOSH Activity . . . . . . . . . . . . . . . . . . . . 2

1.4 Purpose and Scope . . . . . . . . . . . . . . . . . . . . . . 3

2 Properties, Production, and Potential for Exposure . . . . . 4

2.1 Chemical and Physical Properties. . . . . . . . . . . . . . . . . . . . . . . 4

2.2 Number of Workers Potentially Exposed . . . . . . . . . . . . . . . . . 4

2.3 Dust-Generating Activities, Uses, and Potential Exposures. . . . . . . . . . . . 4

2.4 Sampling and Analytical Methods . . . . . . . . . . . . . . . 6

2.4 .1 Sampling Methods . . . . . . . . . . . . . . . . . . . . . . . . 12

2.4 .2 Analytical Methods . . . . . . . . . . . . . . . . . . 12

2.4.3 Feasibility of Measuring Crystalline Silica at Various Concentrations . . . . . . . . . . . . . . . 17

3 Human Health Effects .............. 21

3.1 Epidemiologic Considerations in Occupational Respiratory Disease Studies. . . 21

3.1 .1 Study Designs . . . . . . . . . . . . . . . . . . . . . . . 21

3.1 .2 Sources of Bias. . . . . . . . . . . . . . . . . 22

3.2 Silicosis. . . . . . . . . . . . . . . . . . . . 23

3.2 .1 Definition . . . . . . . . . . . . . . . . 23

3.2.2 Epidemiologic Exposure-Response Models of Silicosis . . . . . . . . . 24

3.3 TB and Other Infections. . . . . . . . . . . . . . . . 33

3.3 .1 Definition . . . . . . . . . . . . . . . . . 33

3.3.2 Epidemiologic Studies . . . . . . . . . . . . . . . . 33 
3.4 Cancer . . . . . . . . . . . . . . . . . . . 35

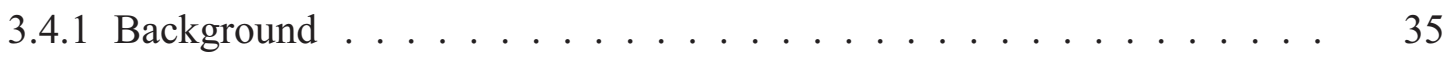

3.4.2 Epidemiologic Studies of Lung Cancer $\ldots \ldots \ldots \ldots$

3.4 .3 Other Cancers . . . . . . . . . . . . . . . . . . . 51

3.5 Other Nonmalignant Respiratory Diseases and Related Conditions . . . . . . 51

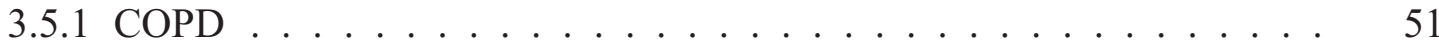

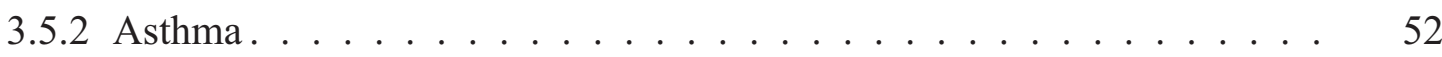

3.5.3 Chronic Bronchitis . . . . . . . . . . . . . . . . . . . 52

3.5.4 Abnormalities in Pulmonary Function Tests . . . . . . . . . . . . 59

3.5 .5 Emphysema . . . . . . . . . . . . . . . . . . . 60

3.5.6 Nonmalignant Respiratory Disease (NMRD) Mortality . . . . . . . . . 62

3.6 Autoimmune and Chronic Renal Diseases . . . . . . . . . . . . . . 67

3.7 Other Health Effects $\ldots \ldots \ldots$

4 Experimental Studies. ............ 80

4.1 Biomarkers . . . . . . . . . . . . . . . . . . . . . 80

4.2 Cytotoxicity. . . . . . . . . . . . . . . . . . . . . 89

4.3 Genotoxicity and Related Effects . . . . . . . . . . . . . . . . . . . . 89

4.4 Carcinogenicity . . . . . . . . . . . . . . . . . . . 91

5 Conclusions ................... 96

5.1 Lung Cancer . . . . . . . . . . . . . . . . . . . . . . . . . 96

5.2 Noncarcinogenic Health Effects . . . . . . . . . . . . . . . . . . . . . 96

5.3 Exposures, Monitoring, and Controls . . . . . . . . . . . . . . . . 97

6 Research Needs .............. 99

6.1 Health-Related Research . . . . . . . . . . . . . . . . . . . . . . . . . . . . . 99

6.2 Research Related to Exposure Measurement . . . . . . . . . . . . . . . . . 100

6.3 Research Related to the Control of Exposure . . . . . . . . . . . . . . . . 101

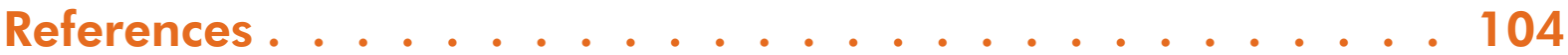

Appendix. Occupational Exposure Limits . . . . . . . . . 127 


\section{Abbreviations}

\begin{tabular}{ll} 
ACGIH & American Conference of Governmental Industrial Hygienists \\
AMG & alpha-1-microglobulin \\
ATS & American Thoracic Society \\
BAL & bronchoalveolar lavage \\
BMG & beta-1-microglobulin \\
BMI & body mass index \\
${ }^{\circ} \mathrm{C}$ & degree(s) Celsius \\
CA & chromosomal aberration(s) \\
cc & cubic centimeter \\
CDC & Centers for Disease Control and Prevention \\
CEN & European Standardization Committee \\
$\mathrm{CFR}$ & Code of Federal Regulations \\
$\mathrm{CI}$ & confidence interval \\
$\mathrm{cm}$ & centimeter(s) \\
$\mathrm{COC}$ & census occupation code \\
$\mathrm{COPD}$ & chronic obstructive pulmonary disease \\
$\mathrm{Cu}$ & copper \\
$\mathrm{CV}$ & coefficient of variation \\
$\overline{\mathrm{CV}}$ & pooled coefficient of variation \\
$\mathrm{CWP}$ & coal workers' pneumoconiosis \\
$\mathrm{DE}$ & diatomaceous earth \\
$\mathrm{DLCO}$ & diffusing capacity of the lung for carbon monoxide \\
$\mathrm{DNA}$ & deoxyribonucleic acid \\
$\mathrm{EPA}$ & U.S. Environmental Protection Agency \\
$\mathrm{FEV}$ & degree(s) Fahrenheit \\
FVC & forced expiratory volume in 1 second \\
& forced vital capacity \\
\hline $\mathrm{C}$ &
\end{tabular}




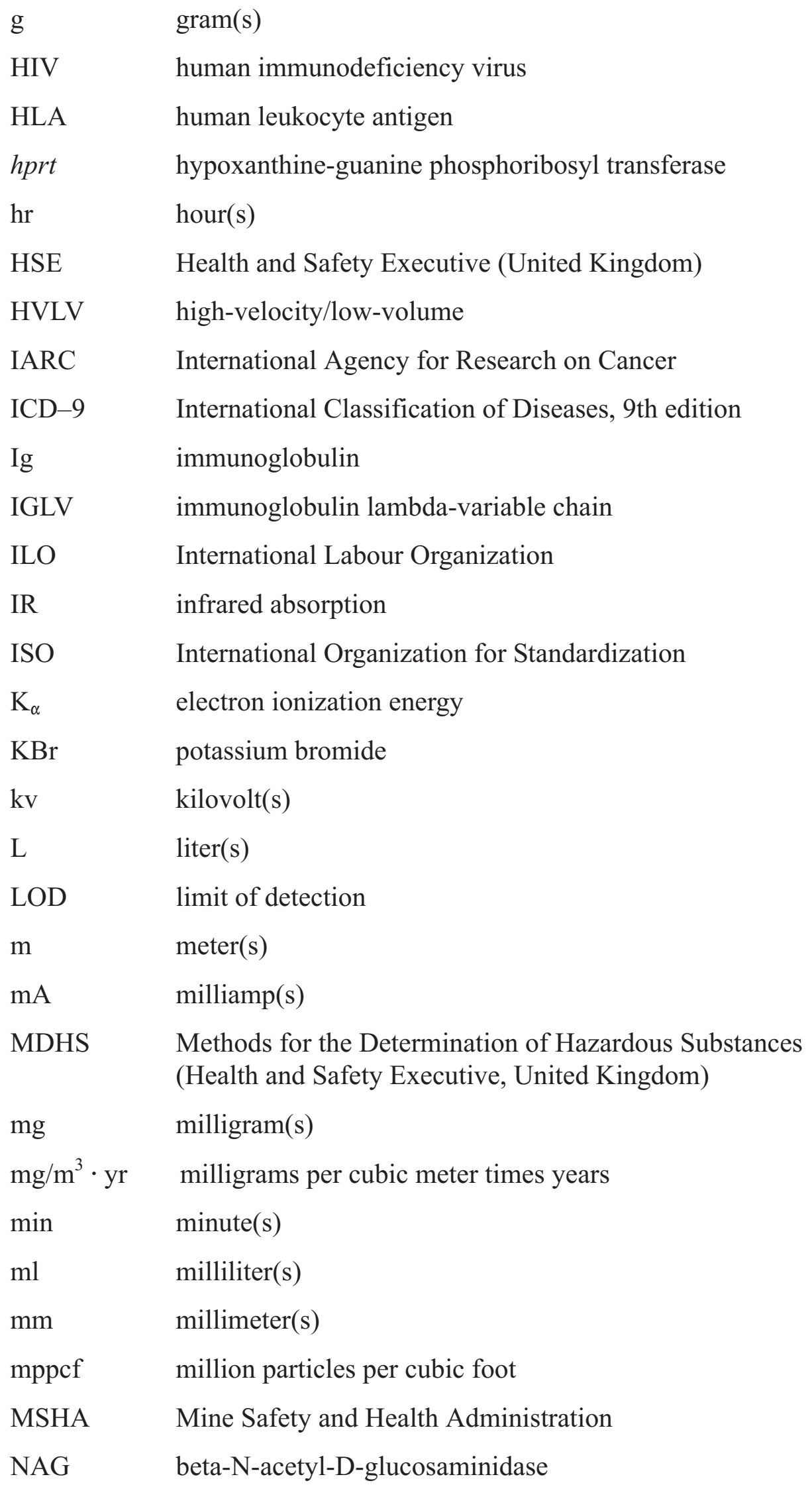




\begin{tabular}{ll} 
NIOSH & National Institute for Occupational Safety and Health \\
NIST & National Institute of Standards and Technology \\
NMRD & nonmalignant respiratory disease \\
NOES & National Occupational Exposure Survey \\
NOHSM & National Occupational Health Survey of Mining \\
NOMS & U.S. National Occupational Mortality Surveillance \\
NTM & nontuberculous mycobacteria \\
OR & odds ratio \\
OSHA & Occupational Safety and Health Administration \\
$P$ & probability \\
PAP & pulmonary alveolar proteinosis \\
PAT & proficiency analytical testing \\
PDGF & platelet-derived growth factor \\
PEL & permissible exposure limit \\
PMR & proportionate mortality ratio \\
ppm & parts per million \\
PVC & polyvinyl chloride \\
RDS & respirable dust standard \\
REL & recommended exposure limit \\
RF & radio frequency \\
RFLP & restriction fragment length polymorphism \\
ROS & reactive oxygen species \\
RSD & relative standard deviation \\
\hline RSD & pooled relative standard deviation \\
SCE & sister chromatid exchange \\
SCG & single cell gel/comet \\
SIC & standard industrial classification \\
SiO & silicon dioxide \\
SIR & standardized incidence ratio \\
SMR & standardized mortality ratio \\
\hline
\end{tabular}




$\begin{array}{ll}\text { SRR } & \text { standardized rate ratio } \\ \text { TGF } & \text { transforming growth factor } \\ \text { TB } & \text { pulmonary tuberculosis } \\ \text { THF } & \text { tetrahydrofuran } \\ \text { TWA } & \text { time-weighted average } \\ \text { U.K. } & \text { United Kingdom } \\ \text { U.S. } & \text { United States } \\ \text { VC } & \text { vital capacity } \\ \text { WASP } & \text { Workplace Analysis Scheme for Proficiency } \\ \text { WHO } & \text { World Health Organization } \\ \text { wk } & \text { week(s) } \\ \text { XRD } & \text { X-ray diffraction } \\ \text { yr } & \text { year(s) } \\ \mu \text { g } & \text { microgram(s) } \\ \mu \mathrm{m} & \text { micrometer(s) } \\ \% & \text { percent }\end{array}$




\section{Glossary}

Aerodynamic diameter: The diameter of a sphere with a density of $1 \mathrm{~g} / \mathrm{cm}^{3}$ and with the same velocity (due to gravity) as the particle of interest [EPA 1996]. Particles of a given aerodynamic diameter move within the air spaces of the respiratory system identically, regardless of density or shape [NIOSH 1995a].

Chronic obstructive pulmonary disease (COPD): Includes airways diseases such as asthma, chronic bronchitis, and emphysema and is characterized by airways dysfunction [Becklake 1992].

Clearance: The translocation and removal of deposited particles from the respiratory tract.

Concentration: The amount of a substance (e.g., dust particles) contained per unit volume of air.

Confidence interval (CI), confidence limits: A range of values (determined by the degree of presumed random variability in the data) within which the value of a parameter (e.g., a mean or relative risk) is believed to lie with the specified level of confidence. The boundaries of a confidence interval are the confidence limits [Last 1988]. These include the lower confidence limit and the upper confidence limit.

Crystalline silica (or free silica): Silicon dioxide $\left(\mathrm{SiO}_{2}\right)$. "Crystalline" refers to the orientation of $\mathrm{SiO}_{2}$ molecules in a fixed pattern as opposed to a nonperiodic, random molecular arrangement defined as amorphous. The three most common crystalline forms of silica encountered in the workplace environment are quartz, tridymite, and cristobalite [NIOSH 1974].

ILO category: The determination of profusion of small opacities observed by reading chest radiographs according to classification of pneumoconioses guidelines developed by the International Labour Organization (ILO). The latest classification guidelines were published by the International Labour Office in 1980 [ILO 1980].

Incidence: The frequency with which new cases of a disease occur in a given time period.

Incidence rate: The rate at which new events occur in a population. The number of new events (e.g., new cases of a disease diagnosed or reported during a defined period) is divided by the number of persons in the population in which the cases occurred [Last 1988].

Inhalable dust: The particulate mass fraction of dust in the work environment that can be inhaled and deposited anywhere in the respiratory tract.

Nontuberculous mycobacteria: Mycobacteria species other than the Mycobacterium tuberculosis complex (e.g., Mycobacterium avium complex). 
Prevalence: The number of disease cases in a specific population at a particular time [Last 1988].

Prevalence rate (ratio): The total number of all individuals with an attribute or disease at a given time or during a given period divided by the population at risk of having the attribute or disease at this point in time or midway through the period [Last 1988].

Proportionate mortality ratio (PMR): Ratio of the proportion of deaths from a specific cause in an exposed population compared with the corresponding ratio in the nonexposed population. For example, the proportion of deaths from disease $\mathrm{X}$ in the exposed population could be compared with the proportion of deaths from disease $\mathrm{X}$ in the nonexposed population [NIOSH 2000].

Quartz: Crystalline silicon dioxide $\left(\mathrm{SiO}_{2}\right)$ not chemically combined with other substances and having a distinctive physical structure.

Respirable crystalline silica: That portion of airborne crystalline silica that is capable of entering the gas-exchange regions of the lungs if inhaled; by convention, a particle-size-selective fraction of the total airborne dust; includes particles with aerodynamic diameters less than approximately $10 \mu \mathrm{m}$ and has a $50 \%$ deposition efficiency for particles with an aerodynamic diameter of approximately $4 \mu \mathrm{m}$.

Sarcoidosis: A rare multisystem granulomatous disease characterized by alterations in the immune system [Fanburg 1992].

Scleroderma (progressive systemic sclerosis): A rare multisystem disorder characterized by inflammatory, vascular, and fibrotic changes usually involving the skin, blood vessels, joints, and skeletal muscle [Archer and Gordon 1996].

Standardized mortality ratio: The ratio of the number of deaths observed in the study population to the number of deaths expected if the study population had the same rate structure as the standard population [Last 1988].

Standardized rate ratio: A rate ratio in which the numerator and denominator rates have been standardized to the same (standard) population distribution [Last 1988]. 


\section{Acknowledgments}

T his Hazard Review was developed by the staff of the National Institute for Occupational Safety and Health (NIOSH). Paul A. Schulte, Director, Education and Information Division (EID), had overall responsibility for the document. Faye L. Rice (EID) was the principal author. The analytical methods section was prepared by Rosa Key-Schwartz, Ph.D.; David Bartley, Ph.D; Paul Baron, Ph.D; and Paul Schlecht. Michael Gressel and Alan Echt contributed material on control technology.

The following NIOSH staff provided critical review and comments on this document and previous versions: Martin Abell; Heinz W. Ahlers, J.D.; Rochelle Althouse; Harlan Amandus, Ph.D.; Michael Attfield, Ph.D.; Nancy Bollinger, Ph.D.; Lorraine Cameron, Ph.D.; Robert Castellan, M.D.; Joseph Cocalis; Joseph Costello; Clayton Doak; Jerome Flesch; Bryan Hardin, Ph.D.; Kent Hatfield, Ph.D.; Frank Hearl; Paul Hewett, Ph.D.; Eva Hnizdo, Ph.D. (formerly of the National Centre for Occupational Health, South Africa); Michael Jacobsen, Ph.D. (visiting scientist); Kathleen Kreiss, M.D.; Kenneth Linch; Charles Lorberau; Tong-man Ong, Ph.D.; John Parker, M.D.; Larry Reed; Karl Sieber, Ph.D.; Rosemary Sokas, M.D.; Leslie Stayner, Ph.D.; Kyle Steenland, Ph.D.; Patricia Sullivan, Sc.D.; Marie Haring Sweeney, Ph.D.; Gregory Wagner, M.D.; William Wallace, Ph.D.; Joann Wess; Ralph Zumwalde.

Editorial review and camera-copy production were provided by Vanessa L. Becks, Susan E. Feldmann, Joyce D. Godfrey, Anne C. Hamilton, Susan R. Kaelin, Laura A. Stroup, Kristina M. Wasmund, and Jane B. Weber. Dale Camper and Ronald Schuler performed literature searches, and the EID Library staff collected literature used in the development of the document.

NIOSH also appreciates the comments of the following external reviewers:

William Beckett, M.D., M.P.H.

University of Rochester School of Medicine

P.O. Box EHSC

575 Elmwood Avenue

Rochester, NY 14642

Harvey Checkoway, Ph.D.

Department of Environmental Health

University of Washington

Box 357234

Seattle, WA 98195-7234

Gerald S. Davis, M.D.

University of Vermont College of Medicine

Pulmonary Unit

Given C317

Burlington, VT 05405
Jeffrey Gift, Ph.D.

Senior Health Scientist

U.S. Environmental Protection Agency

NCEA-RTP Maildrop 52

Research Triangle Park, NC 27711

David Goldsmith, Ph.D.

Department of Environmental and

Occupational Health

George Washington University

2300 K Street, N.W., Suite 201

Washington, DC 20037

Eva Hnizdo, Ph.D.

Epidemiology and Surveillance Section

National Centre for Occupational Health

P.O. Box 4788

Johannesburg 2000, South Africa 
Janet Hughes, Ph.D.

Department of Biostatistics and Epidemiology

Tulane School of Public Health and Tropical Medicine

1430 Tulane Avenue

New Orleans, LA 70112

Carol Jones, Ph.D.

Senior Health Specialist

Mine Safety and Health Administration

4015 Wilson Boulevard, Room 622

Arlington, VA 22203

William Kojola

American Federation of Labor and

Congress of Industrial Organizations

Department of Occupational Safety and Health

815 Sixteenth Street, N.W.

Washington, DC 20006

Allen G. Macneski

Manager, Environmental Safety and Health

Bechtel National, Inc.

151 Lafayette Drive

Oak Ridge, TN 37830

Michelle Schaper, Ph.D.

Toxicologist

Directorate of Technical Support

Mine Safety and Health Administration

4015 Wilson Boulevard, Room 622

Arlington, VA 22203
Loretta Schuman, Ph.D.

Directorate of Health Standards Program

Occupational Safety and Health

Administration

200 Constitution Avenue, N.W., Room N3718

Washington, DC 20210

James Sharpe

Director of Safety and Health Services

National Stone Association

1415 Elliot Place, N.W.

Washington, DC 20007-2599

David M. Tucker

Manager, Industrial Hygiene

Norfolk Southern Corporation

Environmental Protection

110 Franklin Road, S.E.

Box 13

Roanoke, VA 24042-0013

John A. Ulizio

Vice President

U.S. Silica Company

P.O. Box 187

Berkeley Springs, WV 25411

James L. Weeks, Sc.D.

George Washington University Medical Center

Division of Occupational and

Environmental Medicine

2300 K Street, N.W., Suite 201

Washington, DC 20037

References and information were submitted by William G.B. Graham, M.D., University of Vermont, College of Medicine. The author especially thanks David Goldsmith, Ph.D., for his major contribution and efforts on a previous draft. 


\section{Introduction}

\subsection{Definition of Crystalline Silica}

Silica refers to the chemical compound silicon dioxide $\left(\mathrm{SiO}_{2}\right)$, which occurs in a crystalline or noncrystalline (amorphous) form. Crystalline silica may be found in more than one form (polymorphism). The polymorphic forms of crystalline silica are alpha quartz, beta quartz, tridymite, cristobalite, keatite, coesite, stishovite, and moganite [Ampian and Virta 1992; Heaney 1994; Guthrie and Heaney 1995]. Each polymorph is unique in its spacing, lattice structure, and angular relationship of the atoms. In nature, the alpha (or low) form of quartz is the most common [Virta 1993]. This form is so abundant that the term quartz is often used in place of the general term crystalline silica [BOM 1992; Virta 1993]. Quartz is a common component of soil and rocks; consequently, workers are potentially exposed to quartz dust in many occupations and industries (see Section 2.3). Cristobalite and tridymite are found in rocks and soil and are produced in some industrial operations when alpha quartz or amorphous silica is heated (such as foundry processes, calcining of diatomaceous earth, brick and ceramics manufacturing, and silicon carbide production) [NIOSH 1974; Weill et al. 1994; Virta 1993; Altieri et al. 1984]. Burning of agricultural waste or products such as rice hulls may also cause amorphous silica to become cristobalite (a crystalline form) [Rabovsky 1995; IARC 1997]. The other polymorphs (i.e., keatite, coesite, stishovite, and moganite) are rarely or never observed in nature [Ampian and Virta 1992].

\subsection{Current Health Issues}

Occupational exposure to respirable crystalline silica is a serious but preventable health hazard. Since 1968, reported mortality associated with silicosis has declined; however, 200 to 300 such deaths were reported each year during the period 1992-1995 [NIOSH 1996a; Althouse 1998]. Furthermore, the number of silicosis-related deaths among persons aged 15 to 44 did not decline substantially during 1968-1994, accounting for 207 of the 14,824 silicosis-related deaths during this period [CDC 1998a,b]. In addition, an unknown number of unreported or undiagnosed worker deaths occur each year from silicosis and other silica-related diseases such as pulmonary tuberculosis (TB), lung cancer, and scleroderma. The number of current cases of silicosis and silica-related disease in the United States is also unknown.

Prevention and elimination of silicosis and silica-related disease in the United States are priorities of the National Institute for Occupational Safety and Health (NIOSH), the Occupational Safety and Health Administration (OSHA), the Mine Safety and Health Administration (MSHA), and the American Lung Association [DOL 1996]. International health agencies have also expressed concern about the continuing occurrence of silicosis and silica-related diseases. The International Agency for Research on Cancer (IARC) recently reviewed the results of post-1986 epidemiologic studies of lung cancer and occupational exposure to crystalline silica. They concluded that there is "sufficient evidence in 
humans for the carcinogenicity of inhaled crystalline silica in the form of quartz or cristobalite from occupational sources" (i.e., IARC category "Group 1" carcinogen) [IARC 1997]. In 1991, the International Labour Office published a document describing methods for preventing and controlling occupational lung diseases, including silicosis [ILO 1991]. And in 1993, the Office of Occupational Health of the World Health Organization (WHO) called for increased medical surveillance of mineraldust-exposed workers to prevent pneumoconioses such as silicosis and asbestosis [WHO 1993]. Epidemiologic studies published after the IARC review [IARC 1997] provide additional evidence for an exposure-response relationship of respirable crystalline silica with lung cancer mortality or morbidity (see Section 3.4.2.1).

Several recent epidemiologic studies indicate that current occupational standards are not sufficiently protective to prevent the occurrence of chronic silicosis. Epidemiologic studies of workers in the United States [Kreiss and Zhen 1996; Steenland and Brown 1995a; Rosenman et al. 1996; Hughes et al. 1998], Canada [Muir et al. 1989a,b; Muir 1991], Hong Kong [Ng and Chan 1994], and South Africa [Hnizdo and Sluis-Cremer 1993] have reported significant risks of silicosis over a working lifetime at concentrations of quartz or respirable dust containing quartz that are below the current NIOSH recommended exposure limit (REL) [NIOSH 1974], OSHA permissible exposure limit (PEL) [29 CFR $\left.{ }^{*} 1910.1000\right]$, and the MSHA PEL [30 CFR 56, 57, 70, 71] (see Appendix and Table 12 in Chapter 3).

TB is an infectious disease that poses a threat to the health of silica-exposed workers and the public. A survey of U.S. mortality data for

\footnotetext{
${ }^{*}$ Code of Federal Regulations. See CFR in references.
}

1979 to 1991 reported that TB comortality was at least several times higher in decedents with silicosis than in decedents with asbestosis, with coal workers' pneumoconiosis (CWP), or without silicosis, asbestosis, or CWP [Althouse et al. 1995]. The U.S. Centers for Disease Control and Prevention (CDC), WHO, and the American Thoracic Society (ATS) have recently published information about risk factors for TB, including occupational exposure to respirable crystalline silica [CDC 1995; WHO 1996; ATS 1997]. The U.S. Environmental Protection Agency (EPA) suggested "further investigation" of the health effects of ambient crystalline silica exposures in potentially sensitive subgroups, including infants and persons with a respiratory infection or disease such as TB or pneumonia [EPA 1996].

Recent epidemiologic studies of occupational exposure to crystalline silica dust have also reported increased incidence of - or mortality from - extrapulmonary diseases such as scleroderma, rheumatoid arthritis, other autoimmune disorders, and renal disease [ATS 1997].

Experimental research has shown that crystalline silica is not an inert dust. The toxicity of crystalline silica particles is related to reactive sites on the surfaces of silica particles. Further discussion of in vitro studies of the biologic activity and factors that modify toxicity are found in Section 3.2.1 and Section 4.

\subsection{History of NIOSH Activity}

In 1974, NIOSH reviewed the available health effects data on occupational exposure to respirable crystalline silica and determined that the principal adverse health effect was silicosis [NIOSH 1974]. At that time, NIOSH recommended that occupational exposure to respirable crystalline silica dust be controlled so that workers would not be exposed to the airborne particulate at a time-weighted average (TWA) 
concentration greater than 50 micrograms per cubic meter of air $\left(50 \mu \mathrm{g} / \mathrm{m}^{3}\right.$ - or $\left.0.05 \mathrm{mg} / \mathrm{m}^{3}\right)$, determined during a full-shift sample for up to a 10-hr workday during a 40-hr workweek. A later NIOSH report (Review of the Literature on Crystalline Silica) concluded that additional toxicologic and epidemiologic studies were needed to determine (1) the relationship between respirable crystalline silica dose and the risk of developing silicosis and lung cancer and (2) the adverse effects of crystalline silica on the kidney [NIOSH 1983a]. Since then, additional studies reported an increased incidence of malignant tumors in the lungs of rats exposed to either inhalation or intratracheal administration of various forms and preparations of respirable crystalline silica [Holland et al. 1986; Dagle et al. 1986; Groth et al. 1986; Muhle et al. 1989; Spiethoff et al. 1992]. On the basis of the evidence from the animal studies published by 1986, IARC concluded that "sufficient evidence" existed for the carcinogenicity of respirable crystalline silica in experimental animals but only "limited evidence" existed for carcinogenicity in humans [IARC 1987]. During the 1988 OSHA rulemaking activity on air contaminants, NIOSH recommended an exposure limit of $0.05 \mathrm{mg} / \mathrm{m}^{3}$ "as respirable free silica for all crystalline forms of silica" to protect workers from silicosis and cancer [54 Fed. Reg. 2521 (1989)]. In addition, NIOSH testimony referred to the IARC [1987] review and recommended that OSHA label crystalline silica a potential occupational carcinogen [54 Fed. Reg. 2521 (1989)].

\subsection{Purpose and Scope}

The numerous health effects of occupational exposure to respirable crystalline silica are reviewed in the chapters of several recent books [Graham 1998; Davis 1996; Green and Vallyathan 1996; McDonald 1996; Seaton 1995; Morgan and Reger 1995; Elmes 1994; Goldsmith 1994a,b; Weill et al. 1994; Wagner 1994]. This NIOSH Hazard Review summarizes the health effects of occupational exposure to respirable crystalline silica reported in literature published through March 1999. The review emphasizes recent important epidemiologic studies of occupational exposure to respirable crystalline silica with regard to (1) the quantitative risk of chronic silicosis, (2) lung cancer, (3) autoimmune disease, (4) chronic renal disease, and (5) chronic obstructive pulmonary disease. In addition, the review describes limitations of the current sampling and analytical methods for quantifying occupational exposures to silica.

*Federal Register. See Fed. Reg. in references. 


\section{Properties, Production, and Potential for Exposure}

\subsection{Chemical and Physical Properties}

In the crystalline state, one silicon atom and four oxygen atoms are arranged in an ordered, repetitive array of three-dimensional tetrahedrons. The silicon atom is the center of the tetrahedron. Each of the four corners consists of a shared oxygen atom.

Exposure to changes in temperature and pressure, either natural or synthetic, may cause the crystalline structure to change [Iler 1979; Klein and Hurlbut 1993; Navrotsky 1994; Hemley et al. 1994; IARC 1997]. An example of a naturally occurring pressure change is the transformation of alpha quartz to coesite in a rock subjected to the impact of a large meteorite [Iler 1979; Klein and Hurlbut 1993; IARC 1997]. Alpha quartz and beta quartz are the respective designations given to the low- and high-temperature crystal structures. Quartz changes from the alpha to the beta form at $573{ }^{\circ} \mathrm{C}\left(1,063{ }^{\circ} \mathrm{F}\right)$ [Ampian and Virta 1992; NIOSH 1983a; Virta 1993; Guthrie and Heaney 1995].

The solubility of quartz in water at room temperature ranges from 6 to 11 micrograms per cubic centimeter $\left(\mu \mathrm{g} / \mathrm{cm}^{3}\right)$ (6 to 11 parts per million [ppm]) as $\mathrm{SiO}_{2}$ [Coyle 1982; Iler 1979]. Quartz is slightly soluble in body fluids, where it forms silicic acid and is excreted by the urinary system [IARC 1987]. The amount of silica dissolved depends on various factors, including particle size, shape, and structure; solution temperature; viscosity; $\mathrm{pH}$; the pro- portion of dust to liquid; and the presence of trace minerals [King and McGeorge 1938; King 1937; Iler 1979; Wiecek 1988; IARC 1997; Guthrie 1997]. However, the dissolution of quartz does not contribute substantially to its clearance or to changes in its biological activity [IARC 1997; Heppleston 1984; Vigliani and Pernis 1958].

\subsection{Number of Workers Potentially Exposed}

NIOSH [1991] estimates that at least 1.7 million U.S. workers are potentially exposed to respirable crystalline silica. This estimate is based on information from the National Occupational Exposure Survey (NOES) [NIOSH 1983b] and the County Business Patterns 1986 [Bureau of the Census 1986]. Table 1 lists the nonmining industries (excluding agriculture) and mining industries with the largest numbers of workers potentially exposed to respirable crystalline silica. In addition, an undetermined portion of the 3.7 million U.S. agricultural workers [Bureau of the Census 1997] may be exposed to dust containing a significant percentage of respirable crystalline silica [Linch et al. 1998].

\subsection{Dust-Generating Activities, Uses, and Potential Exposures}

Crystalline silica (quartz) is a component of nearly every mineral deposit [Greskevitch et al. 1992]. Thus most crystalline silica exposures are to mixed dust with variable silica content that must be measured by dust collection and 
Table 1. Nonmining and mining industries with the largest numbers of U.S. workers potentially exposed to respirable crystalline silica, 1986

\begin{tabular}{|c|c|c|c|}
\hline SIC $^{*}$ & Industry & $\begin{array}{c}\text { Estimated number of } \\
\text { workers potentially } \\
\text { exposed }(1986)^{\dagger}\end{array}$ & $\begin{array}{c}\% \text { total } \\
\text { workers exposed } \\
(\text { NOES })\end{array}$ \\
\hline \multicolumn{4}{|c|}{$\begin{array}{l}\text { Nonmining } \\
\text { industries: }\end{array}$} \\
\hline 174 & Masonry, stonework, tile setting, and plastering & 131,986 & 32.7 \\
\hline 734 & Services to dwellings and other buildings & 65,812 & 10.3 \\
\hline 327 & Concrete, gypsum, and plaster products & 63,456 & 33.3 \\
\hline 176 & Roofing and sheet metal work & 51,153 & 25.3 \\
\hline 356 & General industrial machinery and equipment & 44,991 & 16.2 \\
\hline 807 & Medical and dental laboratories & 37,063 & 30.0 \\
\hline 493 & Combination of gas and electric and other utilities & 35,074 & 21.2 \\
\hline 179 & Miscellaneous special trade contractors & 32,615 & 7.8 \\
\hline 753 & Automotive repair shops & 30,826 & 7.1 \\
\hline 326 & Pottery and related products & 29,772 & 81.7 \\
\hline \multicolumn{4}{|c|}{$\begin{array}{l}\text { Mining } \\
\text { industries: }\end{array}$} \\
\hline 13 & Oil and gas extraction & 408,175 & $100^{\ddagger}$ \\
\hline 12 & Bituminous coal and lignite mining & 174,131 & 100 \\
\hline 14 & $\begin{array}{l}\text { Mining and quarrying of nonmetallic minerals, } \\
\text { except fuels }\end{array}$ & 100,546 & 100 \\
\hline 10 & Metal mining & 39,856 & 100 \\
\hline
\end{tabular}

Source: NIOSH [1991].

*Standard industrial classification.

${ }^{\dagger}$ Estimated number of workers potentially exposed to the hazards of flint, quartz, sand, or silica powder; based on data from the County Business Patterns 1986 [Bureau of the Census 1986] and the National Occupational Exposure Survey (NOES)

[NIOSH 1983b]. For SICs in which the estimates differed for individual hazards, the highest percentage was used for that SIC.

"Exposure is assumed to be $100 \%$ in the mining industries. 
analysis [Wagner 1995; Donaldson and Borm 1998].

Workers in a large variety of industries and occupations may be exposed to crystalline silica because of its widespread natural occurrence and the wide uses of the materials and products containing it. OSHA compliance officers found respirable quartz in 6,779 personal samples (8-hr TWA) taken in 255 industries that were targeted for inspection (excluding mining and agriculture). In $48 \%$ of the industries, average overall exposure exceeded the PEL for respirable quartz [Freeman and Grossman 1995]. Linch et al. [1998] applied an algorithm to OSHA compliance data from the period 1979-1995 and County Business Patterns 1993 data [Bureau of the Census 1993] to estimate the percentage of workers by industry (excluding mining and agriculture) exposed to defined concentrations of respirable crystalline silica (e.g., $\geq 0.05 \mathrm{mg} / \mathrm{m}^{3}$ ) in 1993. Area samples and samples involving complaints to OSHA were excluded from the analysis. Although data limitations could have resulted in underestimating or overestimating the number of workers exposed, the authors found 5 three-digit standardized industrial classification (SIC) codes in which an estimated number of workers were exposed to concentrations at least 10 times the NIOSH REL:

$S I C$

No. workers

174 Masonry and plastering . . . . . . . 13,800 (1.8\%)

162 Heavy construction ........... 6,300 (1.3\%)

172 Painting and paper hanging ...... 3,000 (1.9\%)

332 Iron and steel foundries . . . . . . . $800(0.3 \%)$

347 Metal services ............ $400(0.2 \%)$

Additional three-digit SICs had a number of workers with crystalline silica exposures that were two or five times higher than the NIOSH REL [Linch et al. 1998].
Table 2 lists the main industries around the world in which silica exposure has been reported. Virtually any process that involves movement of earth or disturbance of silicacontaining products such as masonry and concrete may expose a worker to silica (see Table 3 for uses of industrial silica sand and gravel). Table 4 presents, from selected States, the most frequently recorded occupations of U.S. residents aged 15 or above whose death certificates list silicosis as an underlying or contributory cause of death [NIOSH 1996a]. In addition, Table 5 lists published case reports of silicosis in workers from other industries and occupations.

\subsection{Sampling and Analytical Methods}

Historically, several methods have been used to measure worker exposure to airborne crystalline silica (quartz, cristobalite, or tridymite). These methods differ primarily in the analytical technique employed, although they all rely on a collection procedure that uses a cyclone for size-selective sampling. Airborne samples are collected using a cyclone to remove nonrespirable particles and an appropriate filter medium (e.g., polyvinyl chloride) to retain the respirable dust fraction. Preparation of the sample for crystalline silica determination differs depending on the type of analytical technique used. One of three analytical techniques is typically used for the quantitative determination of crystalline silica: X-ray diffraction (XRD) spectrometry, infrared absorption (IR) spectrometry, or colorimetric spectrophotometry. XRD and IR are the most common techniques used for crystalline silica analyses. The quantitative limit of detection for these methods ranges from 5 to $10 \mu \mathrm{g}$ per sample; but the accuracy is poor, particularly at the low filter loadings ( $\leq 30 \mu$ g per sample) that are typically collected when workplace concentrations of airborne crystalline silica are near the NIOSH REL of $50 \mu \mathrm{g} / \mathrm{m}^{3}$ (or $0.05 \mathrm{mg} / \mathrm{m}^{3}$ ). 
Table 2. Main industries and activities around the world in which silica exposure has been reported

\begin{tabular}{|c|c|c|}
\hline Industry or activity & Operations and tasks & Source materials \\
\hline Agriculture & $\begin{array}{l}\text { Plowing, harvesting, using machinery, } \\
\text { burning agricultural waste, processing } \\
\text { agricultural products }\end{array}$ & Soil \\
\hline $\begin{array}{l}\text { Mining and related milling } \\
\text { operations }\end{array}$ & $\begin{array}{l}\text { Most occupations (underground, } \\
\text { surface, mill) and mines (metal and } \\
\text { nonmetal, coal), rock drilling, } \\
\text { dredging }\end{array}$ & Ores, associated rock \\
\hline $\begin{array}{l}\text { Quarrying and related milling } \\
\text { operations }\end{array}$ & $\begin{array}{l}\text { Crushing stone, sand and gravel } \\
\text { processing, stone monument cutting } \\
\text { and abrasive blasting, slate work (e.g., } \\
\text { pencil manufacturing), diatomite } \\
\text { calcination }\end{array}$ & $\begin{array}{l}\text { Sandstone, granite, flint, sand, } \\
\text { gravel, slate, diatomaceous } \\
\text { earth }\end{array}$ \\
\hline Construction & $\begin{array}{l}\text { Abrasive blasting of structures and } \\
\text { buildings, highway and tunnel } \\
\text { construction, excavation and earth } \\
\text { moving and digging, masonry, } \\
\text { concrete work, demolition, dry } \\
\text { sweeping and brushing, pressurized air } \\
\text { blowing, jack hammering, laying } \\
\text { railroad track, removing rust or paint, } \\
\text { sanding and scaling, replacement of } \\
\text { asphalt roofing, and hauling, pouring, } \\
\text { mixing, or dumping silica-containing } \\
\text { materials }\end{array}$ & $\begin{array}{l}\text { Sand, concrete, rock, soil, } \\
\text { mortar, plaster, shingles }\end{array}$ \\
\hline Glass, including fiberglass & $\begin{array}{l}\text { Raw material processing, refractory } \\
\text { installation and repair }\end{array}$ & $\begin{array}{l}\text { Sand, crushed quartz, } \\
\text { refractory materials }\end{array}$ \\
\hline Cement & Raw material processing & $\begin{array}{l}\text { Clay, sand, limestone, } \\
\text { diatomac eous earth }\end{array}$ \\
\hline Abrasives & $\begin{array}{l}\text { Silicon carbide production, abrasive } \\
\text { products fabrication }\end{array}$ & Sand, tripoli, sandstone \\
\hline $\begin{array}{l}\text { Ceramics, including bricks, tiles, } \\
\text { sanitary ware, porcelain, pottery, } \\
\text { refractories, vitreous enamels }\end{array}$ & $\begin{array}{l}\text { Mixing, molding, glaze or enamel } \\
\text { spraying, finishing, sculpting, firing }\end{array}$ & $\begin{array}{l}\text { Clay, shale, flint, sand, } \\
\text { quartzite, diatomaceous earth }\end{array}$ \\
\hline Iron and steel mills & $\begin{array}{l}\text { Refractory preparation and furnace } \\
\text { repair }\end{array}$ & Refractory material \\
\hline
\end{tabular}

(Continued)

Sources: IARC [1987; 1997], NIOSH [1979a; 1983a,b; 1996b], DOL, NIOSH [1997], Fulekar and Alam Khan [1995], Jain et al. [1977], Corn [1980], Webster [1982], Froines et al. [1986], Davis [1996], Weill et al. [1994], Lucas and Salisbury [1992], Pike [1992], McCunney et al. [1987], Fairfax [1998]. 
Table 2 (Continued). Main industries and activities around the world in which silica exposure has been reported

\begin{tabular}{|c|c|c|}
\hline Industry or activity & Operations and tasks & Source materials \\
\hline $\begin{array}{l}\text { Silicon and ferro-silicon foundries } \\
\text { (ferrous and nonferrous) }\end{array}$ & $\begin{array}{l}\text { Raw materials handling, casting, } \\
\text { molding and shaking out, abrasive } \\
\text { blasting, fettling, furnace installation } \\
\text { and repair }\end{array}$ & Sand, refractory material \\
\hline $\begin{array}{l}\text { Metal products, including structural } \\
\text { metal, machinery, transportation } \\
\text { equipment }\end{array}$ & Abrasive blasting & Sand \\
\hline Shipbuilding and repair & Abrasive blasting & Sand \\
\hline Rubber and plastics & Raw materials handling & $\begin{array}{l}\text { Fillers (tripoli, diatomaceous } \\
\text { earth) }\end{array}$ \\
\hline Paint & Raw materials handling, site preparation & $\begin{array}{l}\text { Fillers (tripoli, diatomaceous } \\
\text { earth, silica flour) }\end{array}$ \\
\hline Soaps and cosmetics & $\begin{array}{l}\text { Manufacturing or occupational use of } \\
\text { abrasive soaps and scouring powders }\end{array}$ & Silica flour \\
\hline Roofing asphalt felt & Filling and granule application & $\begin{array}{l}\text { Sand and aggregate, } \\
\text { diatomaceous earth }\end{array}$ \\
\hline Agricultural chemicals & $\begin{array}{l}\text { Raw material crushing, handling, } \\
\text { bagging; or dumping products or raw } \\
\text { materials }\end{array}$ & Phosphate ores and rock \\
\hline Jewelry & $\begin{array}{l}\text { Cutting, grinding, polishing, buffing, } \\
\text { etching, engraving, casting, chipping, } \\
\text { sharpening, sculpting }\end{array}$ & $\begin{array}{l}\text { Semiprecious gems or stones, } \\
\text { abrasives, glass }\end{array}$ \\
\hline Arts, crafts, sculpture & $\begin{array}{l}\text { Pottery firing, ceramics, clay mixing, } \\
\text { kiln repairs, abrasive blasting, sand } \\
\text { blasting, engraving, cutting, grinding, } \\
\text { polishing, buffing, etching, engraving, } \\
\text { casting, chipping, sharpening, } \\
\text { sculpting }\end{array}$ & $\begin{array}{l}\text { Clays, glazes, bricks, stones, } \\
\text { rocks, minerals, sand, silica } \\
\text { flour }\end{array}$ \\
\hline Dental material & Sand blasting, polishing & Sand, abrasives \\
\hline Boiler scaling & Coal-fired boilers & Ash and concretions \\
\hline Automobile repair & $\begin{array}{l}\text { Abrasive blasting, sanding, removing } \\
\text { paint and rust }\end{array}$ & Sand, metals, priming putty \\
\hline
\end{tabular}


Table 3. Industrial silica sand and gravel sold or used by U.S. producers in 1994, by major end use

\begin{tabular}{ll}
\multicolumn{1}{c}{ General use } & \multicolumn{1}{c}{ End use } \\
\hline Sand: & Containers, flat (plate and window), specialty, fiberglass (unground or ground) \\
Glass-making & Molding and core, molding and core facing (ground), refractory \\
Foundry work & Silicon carbide, flux for metal smelting \\
Metallurgical work & Blasting, scouring cleansers (ground), sawing and sanding, chemicals (ground and \\
Abrasive work & unground) \\
Fillers & Rubber, paints, putty, whole grain fillers/building products \\
Ceramics & Pottery, brick, tile \\
Filtration & Water (municipal, county, local), swimming pool, others \\
Petroleum manufacturing & Hydraulic fracturing, well packing, and cementing \\
Recreation & Golf course, baseball, volleyball, play sands, beaches, traction (engine), roofing \\
granules and fillers, other (ground silica or whole grain)
\end{tabular}

Sources: IARC [1997]; BOM [1994]. 
Table 4. Most frequently recorded occupations of U.S. residents aged 15 or above whose death certificates list silicosis as an underlying or contributory cause of death - selected States, 1991-1992*

\begin{tabular}{|c|c|c|c|}
\hline $\mathrm{COC}^{\dagger}$ & Occupation & Number & $\%$ \\
\hline 616 & Mining machine operator & 39 & 16.0 \\
\hline 889 & Laborer, except construction & 29 & 11.9 \\
\hline 019 & Manager or administrator, not elsewhere classified & 11 & 4.5 \\
\hline 633 & Supervisor or precision production occupations & 11 & 4.5 \\
\hline 453 & Janitor, cleaner & 8 & 3.3 \\
\hline 719 & Molding, casting machine operator & 8 & 3.3 \\
\hline 243 & Supervisor or proprietor of sales occupations & 6 & 2.5 \\
\hline 844 & Operating engineer & 6 & 2.5 \\
\hline 637 & Machinist & 5 & 2.1 \\
\hline 787 & Hand molding, casting, and forming occupations & 5 & 2.1 \\
\hline - & All other occupations & 109 & 44.9 \\
\hline - & Occupation not reported & 6 & 2.5 \\
\hline & TOTAL & 243 & $100.1^{\ddagger}$ \\
\hline
\end{tabular}


Table 5. Other occupations ${ }^{*}$ reporting cases of silicosis in workers

\begin{tabular}{|c|c|}
\hline Industry or occupation & Reference \\
\hline Agriculture industry or forestry worker & Fennerty et al. [1983]; Dynnik et al. [1981]; Beaumont et al. [1995] \\
\hline Brewery worker & Nemery et al. [1993] \\
\hline Confectioner & Canessa et al. [1990] \\
\hline Crystal cutter & Suskovic et al. [1990] \\
\hline Drycleaning worker & Seitz et al. [1982] \\
\hline Filter candle production worker & Vigliani and Mottura [1948] \\
\hline Grave digger and well digger & al-Kassimi et al. [1991] \\
\hline Kaolin worker & Rodriguez et al. [1985] \\
\hline Metal polisher & Malik et al. [1985] \\
\hline Pit digger & de Barros Hatem and Cavalcanti [1990] \\
\hline Souvenir casting worker & Carel et al. [1994] \\
\hline Woodworker & Thoreux et al. [1990] \\
\hline
\end{tabular}

*Includes only occupations not listed in Tables 2 or 4. 


\subsubsection{Sampling Methods}

Current sampling methods for crystalline silica involve the use of a cyclone attached to a filter cassette to collect the respirable fraction of the airborne particulate. To minimize measurement bias and variability, these samplers should conform to the criteria of the International Organization for Standardization (ISO), the European Standardization Committee (CEN), and the American Conference of Governmental Industrial Hygienists (ACGIH) for collecting particles of the appropriate size [ISO 1991; CEN 1992; ACGIH 2001]. Also, the cyclone should exhibit sufficient conductivity to minimize the electrostatic effects on particle collection. Cyclones typically used for crystalline silica measurements include the DorrOliver 10-mm nylon cyclone and the HigginsDewell conductive cyclone. These cyclones have been evaluated for their compliance with the ISO/CEN/ACGIH respirable aerosol sampling convention. Flow rates of $1.7 \mathrm{~L} / \mathrm{min}$ for the Dorr-Oliver cyclone and $2.2 \mathrm{~L} / \mathrm{min}$ for the Higgins-Dewell cyclone provide minimum bias for a wide range of particle size distributions that are likely to occur in the workplace [Bartley et al. 1994]. The Dorr-Oliver 10-mm cyclone is required by MSHA, and the HigginsDewell cyclone is used in the United Kingdom. Recently, the GK2.69 cyclone [Kenny and Gussman 1997] has become available with a sampling rate equal to $4.2 \mathrm{~L} / \mathrm{min}$. The GK2.69 cyclone is expected to be at least as adequate as the nylon cyclone for conforming to the ISO/ CEN/ACGIH respirable aerosol sampling convention; and it may be preferable for silica sampling since it is conductive, has welldefined dimensional characteristics, and can be used at higher flow rates for better mass sensitivity. Because each type of cyclone exhibits specific particle collection characteristics, the use of a single cyclone type for each application would be advisable until evidence becomes available indicating that bias among cyclone types will not increase laboratoryto-laboratory variability.
Cyclones and filter cassettes should be leak tested to avoid gross failure in the field. The cyclones may be tested using a simple pressure- (or vacuum-) holding test. The filter cassette should also be checked for leakage while attached to the cyclone. Two approaches to testing the cassettes have been used. A micromanometer has been used to measure the pressure drop across a single type of cassette and compare it with the average pressure drop across well-sealed cassettes [Van den Heever 1994]. An alternative approach uses a particle counter to measure the penetration of submicrometer ambient aerosol through the cassette, with the percentage of penetration serving as an indicator of leakage [Baron 2001]. Measurement of cassette leakage by several laboratories indicates that significant leakage can occur in certain situations. Cassettes should be assembled using a press, and they should be routinely checked for leakage.

\subsubsection{Analytical Methods}

\subsubsection{XRD Spectrometry}

XRD methods used for crystalline silica determination include NIOSH Method 7500 [NIOSH 1998], OSHA Method ID-142 [OSHA 1996], MSHA Method P-2 [MSHA 1999], and the Health and Safety Executive (HSE) Method for the Determination of Hazardous Substances (MDHS) 51/2 [HSE 1988]. Details of these methods are presented in Table 6. XRD is capable of distinguishing the three prevalent polymorphs of crystalline silica (quartz, cristobalite, and tridymite) and can simultaneously analyze for each polymorph while correcting for interferences that may be present on the sample [Madsen et al. 1995]. Although most samples collected in industrial workplaces are relatively free of mineral interferences, an XRD scan of some samples should be performed to ensure the absence of interferences through confirmation of the correct peak ratios for the three largest peaks. 
Table 6. XRD* sampling and analytical methods for crystalline silica

\begin{tabular}{|c|c|c|c|c|}
\hline Item & $\begin{array}{c}\text { NIOSH } \\
\text { Method } 7500\end{array}$ & $\begin{array}{c}\text { OSHA } \\
\text { Method ID-142 }\end{array}$ & $\begin{array}{c}\text { MSHA } \\
\text { Method P-2 }\end{array}$ & MDHS 51/2 \\
\hline Silica polymorph & $\begin{array}{l}\text { Quartz, cristobalite, } \\
\text { tridymite }\end{array}$ & Quartz, cristobalite & Quartz, cristobalite & Quartz \\
\hline Sampler & $\begin{array}{l}\text { 10-mm nylon } \\
\text { cyclone, } 1.7 \mathrm{~L} / \mathrm{min} \text {; } \\
\text { Higgins-Dewell } \\
\text { cyclone, } 2.2 \mathrm{~L} / \mathrm{min}\end{array}$ & $\begin{array}{l}\text { 10-mm nylon } \\
\text { Dorr-Oliver } \\
\text { cyclone, } 1.7 \mathrm{~L} / \mathrm{min}\end{array}$ & $\begin{array}{l}\text { 10-mm nylon } \\
\text { Dorr-Oliver } \\
\text { cyclone, } 1.7 \mathrm{~L} / \mathrm{min}\end{array}$ & $\begin{array}{l}\text { Higgins-Dewell } \\
\text { cyclone, } 1.9 \mathrm{~L} / \mathrm{min}\end{array}$ \\
\hline Filter & $\begin{array}{l}\text { 37-mm, 5- } \mu \mathrm{m} \\
\text { PVC membrane }\end{array}$ & $\begin{array}{l}\text { 37-mm, 5- } \mu \mathrm{m} \\
\text { PVC membrane }\end{array}$ & $\begin{array}{l}\text { 37-mm, 5- } \mu \mathrm{m} \\
\text { PVC membrane }\end{array}$ & $\begin{array}{l}25-\mathrm{mm}, 5-\mu \mathrm{m} \\
\text { PVC membrane }\end{array}$ \\
\hline Volume & $\begin{array}{l}400-1,000 \mathrm{~L} ; \text { total } \\
\text { dust }<2 \mathrm{mg}\end{array}$ & $\begin{array}{l}408-816 \mathrm{~L} \text {; total } \\
\text { dust }<3 \mathrm{mg}\end{array}$ & $\begin{array}{l}400-1,000 \mathrm{~L} ; \text { total } \\
\text { dust }<3 \mathrm{mg}\end{array}$ & $\begin{array}{l}\geq 456 \mathrm{~L} \text {; total } \\
\quad \text { dust }<2 \mathrm{mg}\end{array}$ \\
\hline Filter preparation & $\begin{array}{l}\text { RF plasma asher, } \\
\text { muffle furnace, or } \\
\text { filter dissolution in } \\
\text { THF }\end{array}$ & $\begin{array}{l}\text { Dissolve filter in } \\
\text { THF }\end{array}$ & RF plasma asher & None \\
\hline Redeposition & $\begin{array}{l}\text { On } 0.45-\mu \mathrm{m} \text { silver } \\
\text { membrane filter }\end{array}$ & $\begin{array}{l}\text { On } 0.45-\mu \mathrm{m} \text { silver } \\
\text { membrane filter }\end{array}$ & $\begin{array}{l}\text { On } 0.45-\mu \mathrm{m} \text { silver } \\
\text { membrane filter }\end{array}$ & None \\
\hline Drift correction & $\begin{array}{l}\text { Silver internal } \\
\text { standard }\end{array}$ & $\begin{array}{l}\text { Silver internal } \\
\text { standard }\end{array}$ & $\begin{array}{l}\text { Silver internal } \\
\text { standard }\end{array}$ & $\begin{array}{l}\text { External standard } \\
\text { (e.g., aluminum } \\
\text { plate) }\end{array}$ \\
\hline X-ray source & $\begin{array}{l}\mathrm{Cu} \mathrm{K}{ }_{\alpha} ; 40 \mathrm{kV} \\
35 \mathrm{~mA}\end{array}$ & $\begin{array}{l}\mathrm{Cu} \mathrm{K} ; 40 \mathrm{kV}, \\
40 \mathrm{~mA}\end{array}$ & $\begin{array}{l}\mathrm{Cu} \mathrm{K}_{\alpha} ; 55 \mathrm{kV}, \\
40 \mathrm{~mA}\end{array}$ & $\begin{array}{l}\mathrm{Cu} \mathrm{K}{ }_{\alpha} ; 45 \mathrm{kV}, \\
45 \mathrm{~mA}\end{array}$ \\
\hline Calibration & $\begin{array}{l}\text { Suspensions of } \mathrm{SiO}_{2} \\
\text { in 2-propanol } \\
\text { (deposited on silver } \\
\text { membrane filter) }\end{array}$ & $\begin{array}{l}\text { Suspensions of } \mathrm{SiO}_{2} \\
\text { in 2-propanol } \\
\text { (deposited on silver } \\
\text { membrane filter) }\end{array}$ & $\begin{array}{l}\text { Suspensions of } \\
\mathrm{SiO}_{2} \text { in 2-propanol } \\
\text { (deposited on silver } \\
\text { membrane filter) }\end{array}$ & $\begin{array}{l}\text { Sampling from a } \\
\text { generated } \\
\text { atmosphere of } \\
\text { standard quartz dust }\end{array}$ \\
\hline Proficiency testing & PAT & PAT & PAT & WASP \\
\hline Range ( $\mu$ g quartz) & $20-2000$ & $\begin{array}{l}50-160 \text { (validation } \\
\text { range) }\end{array}$ & $20-500$ & $50-2000$ \\
\hline LOD ( $\mu$ g quartz) & 5 (estimated) & 10 & 5 & 3 \\
\hline Precision & $\begin{array}{l}\overline{\mathrm{RSD}}=0.08 \\
50-200 \mu \mathrm{g}\end{array}$ & $\begin{array}{l}\overline{\mathrm{CV}}=0.106 @ \\
50-160 \mu \mathrm{g}\end{array}$ & $\begin{array}{l}\mathrm{CV}=10 \% @ \\
20-500 \mu \mathrm{g}\end{array}$ & $\mathrm{CV}=5 \% @ 50 \mu \mathrm{g}$ \\
\hline
\end{tabular}

*Abbreviations: $\mathrm{Cu}=$ copper; $\mathrm{CV}=$ coefficient of variation (equivalent to $\mathrm{RSD}$ ); $\overline{\mathrm{cV}}=$ pooled coefficient of variation; $\mathrm{K}_{\alpha}=$ electron ionization energy; $\mathrm{kV}=$ kilovolt(s); LOD = limit of detection; $\mathrm{mA}=$ milliampere(s); MDHS = Methods for the Determination of Hazardous Substances (Health and Safety Executive, United Kingdom); MSHA = Mine Safety and Health Administration; NIOSH = National Institute for Occupational Safety and Health; OSHA = Occupational Safety and Health Administration; PAT = proficiency analytical testing; $\mathrm{PVC}=$ polyvinyl chloride; $\mathrm{RF}$ = radio frequency; $\mathrm{RSD}=$ relative standard deviation; $\overline{\mathrm{RSD}}=$ pooled relative standard deviation (equivalent to $\overline{\mathrm{CV}}$ ); $\mathrm{THF}=$ tetrahydrofuran; WASP $=$ Workplace Analysis Scheme for Proficiency; XRD = X-ray diffraction. 


\subsubsection{IR Spectrometry}

IR methods used for crystalline silica determination include NIOSH Methods 7602 and 7603 [NIOSH 1994a,c], MSHA Method P-7 [MSHA 1994], and MDHS 37 and 38 [HSE 1987, 1984]. Details of these methods are presented in Table 7. Although IR is less specific than XRD (IR methods cannot readily distinguish crystalline silica polymorphs), the technique is less expensive and can be optimized for measuring quartz in well-defined sample matrices [Madsen et al. 1995; Smith 1997; Hurst et al. 1997]. Samples that contain other silicates (such as kaolinite) and amorphous silica can present interferences in the analyses. Also, a potential for bias exists when correcting for matrix absorption effects, with an increasing risk of bias at lower quartz concentrations.

\subsubsection{Colorimetric Spectrophotometry}

The NIOSH colorimetric method for crystalline silica (NIOSH Method 7601) [NIOSH 1994b] is significantly less precise than IR or XRD methods. The colorimetric analytical method exhibits a nonlinear dependence on the mass of crystalline silica present [Eller et al. 1999a]. The linear range of the method is limited, and the blank values for samples can be high $(20 \mu \mathrm{g}$ silica or higher) [Talvitie 1951, 1964; Talvitie and Hyslop 1958]. High intralaboratory variability of the method (up to twice that of IR or XRD) has been noted in studies conducted in the Proficiency Analytical Testing Program (PAT) [Shulman et al. 1992]. The colorimetric method cannot distinguish between silica and silicates, since it is based on the measurement of silicon.

\subsubsection{Factors Affecting the Sensitivity and Accuracy of Analytical Techniques}

Samples prepared for XRD analyses are measured directly (MDHS 51/2) or are redeposited onto 25 -mm silver membrane filters (NIOSH Method 7500 and OSHA Method ID-142). IR samples can be measured directly (MDHS 37), redeposited on an acrylic copolymer membrane filter (NIOSH Method 7603 and MSHA Method P-7), or incorporated into a potassium bromide (KBr) pellet (NIOSH Method 7602 and MDHS 38). Techniques used for redepositing the sample (both IR and XRD) are difficult to perform at low sample loadings and require the laboratory analyst to demonstrate good intralaboratory reproducibility. However, these techniques can be optimized by preparing multiple working standards from multiple suspensions of calibration standards and by ensuring that the sample is redeposited evenly as a thin layer on the filter. No statistically significant difference has been observed between ashing the filter (muffle furnace and low-temperature asher) and dissolving the filter by tetrahydrofuran before redepositing the sample [Eller et al. 1999a].

The instrument response of all three analytical techniques is influenced by the size of the particles in the sample. With XRD, the diffraction intensity (as measured by peak height) can vary considerably with particle size, with smaller particles showing lower intensities [Bhaskar et al. 1994]. The sensitivity of IR analyses decreases with increasing particle size. The colorimetric method requires the use of a precisely timed heating step with phosphoric acid to digest amorphous silica and silicates during sample preparation, causing a possible loss of some small crystalline silica particles [Eller et al. 1999a]. Since particle size affects the sensitivity of all three analytical techniques, the particle size distribution of the calibration standard should closely match the size of the particles retained on the collected sample.

For all analytical techniques, strict adherence to standardized procedures is necessary to produce accurate results. Specifically, appropriate 
Table 7. IR* sampling and analytical methods for crystalline silica

\begin{tabular}{|c|c|c|c|c|c|}
\hline Item & $\begin{array}{c}\text { NIOSH } \\
\text { Method } 7602\end{array}$ & $\begin{array}{c}\text { NIOSH } \\
\text { Method } 7603\end{array}$ & MSHA P-7 & MDHS 37 & MDHS 38 \\
\hline Matrix & & Coal mine dust & Coal mine dust & & \\
\hline Sampler & $\begin{array}{l}\text { 10-mm nylon } \\
\text { cyclone, } 1.7 \mathrm{~L} / \mathrm{min} \text {; } \\
\text { Higgins-Dewell } \\
\text { cyclone, } 2.2 \mathrm{~L} / \mathrm{min}\end{array}$ & $\begin{array}{l}10-\mathrm{mm} \text { nylon } \\
\text { cyclone, } \\
1.7 \mathrm{~L} / \mathrm{min} ; \\
\text { Higgins-Dewell } \\
\text { cyclone, } \\
2.2 \mathrm{~L} / \mathrm{min}\end{array}$ & $\begin{array}{l}10-\mathrm{mm} \text { nylon } \\
\text { Dorr-Oliver } \\
\text { cyclone, } \\
2.0 \mathrm{~L} / \mathrm{min}\end{array}$ & $\begin{array}{l}\text { Higgins-Dewell } \\
\text { cyclone, } \\
1.9 \mathrm{~L} / \mathrm{min}\end{array}$ & $\begin{array}{l}\text { Higgins- } \\
\text { Dewell } \\
\text { cyclone, } \\
1.9 \mathrm{~L} / \mathrm{min}\end{array}$ \\
\hline Filter & $\begin{array}{l}37-\mathrm{mm} \text { filter; } 5-\mu \mathrm{m} \\
\text { PVC or MCE } \\
\text { membrane }\end{array}$ & $\begin{array}{l}\text { 37-mm filter; } \\
5-\mu \mathrm{m} \text { PVC } \\
\text { membrane }\end{array}$ & $\begin{array}{l}\text { 37-mm filter; } \\
5-\mu \mathrm{m} \text { PVC } \\
\text { membrane, } \\
\text { preweighed }\end{array}$ & $\begin{array}{l}\text { 37-mm filter; } \\
5 \text { - } \mu \mathrm{m} \text { PVC } \\
\text { membrane }\end{array}$ & $\begin{array}{l}\text { 37-mm filter; } \\
5-\mu \mathrm{m} \text { PVC } \\
\text { membrane }\end{array}$ \\
\hline Volume & $\begin{array}{l}400-800 \mathrm{~L} \text {; total } \\
\text { dust }<2 \mathrm{mg}\end{array}$ & $\begin{array}{l}300-1,000 \mathrm{~L} ; \\
\text { total dust }<2 \mathrm{mg}\end{array}$ & Not stated & $\begin{array}{l}\geq 456 \mathrm{~L} \text {; total } \\
\text { dust }<1 \mathrm{mg}\end{array}$ & $\begin{array}{l}\geq 456 \mathrm{~L} \\
\text { total dust } \\
<0.7 \mathrm{mg}\end{array}$ \\
\hline $\begin{array}{l}\text { Filter } \\
\text { preparation }\end{array}$ & $\begin{array}{l}\text { RF plasma asher or } \\
\text { muffle furnace }\end{array}$ & $\begin{array}{l}\text { RF plasma } \\
\text { asher or muffle } \\
\text { furnace }\end{array}$ & RF plasma asher & None & Muffle furnace \\
\hline $\begin{array}{l}\text { Analytical } \\
\text { sample } \\
\text { preparation }\end{array}$ & $\begin{array}{l}\text { Mix residue with } \\
\mathrm{KBr} \text {, press } \\
13-\mathrm{mm} \text { pellet }\end{array}$ & $\begin{array}{l}\text { Redeposit on } \\
0.45-\mu \mathrm{m} \text { acrylic } \\
\text { copolymer filter }\end{array}$ & $\begin{array}{l}\text { Redeposit on } \\
0.45-\mu \mathrm{m} \text { acrylic } \\
\text { copolymer filter }\end{array}$ & None & $\begin{array}{l}\text { Mix residue } \\
\text { with } \mathrm{KBr}, \\
\text { press } 13-\mathrm{mm} \\
\text { pellet }\end{array}$ \\
\hline Standard & Polystyrene film & Polystyrene film & Polystyrene film & Polystyrene film & $\begin{array}{l}\text { Polystyrene } \\
\text { film }\end{array}$ \\
\hline Calibration & $\begin{array}{l}\text { Quartz diluted in } \\
\mathrm{KBr}\end{array}$ & $\begin{array}{l}\text { Standard } \\
\text { suspension of } \\
\text { quartz in } \\
\text { 2-propanol }\end{array}$ & $\begin{array}{l}\text { Standard } \\
\text { suspension of } \\
\text { quartz in } \\
\text { 2-propanol }\end{array}$ & $\begin{array}{l}\text { Sampling from } \\
\text { a generated } \\
\text { atmosphere of } \\
\text { standard quartz } \\
\text { dust }\end{array}$ & $\begin{array}{l}\text { Sampling from } \\
\text { a generated } \\
\text { atmosphere of } \\
\text { standard quartz } \\
\text { dust }\end{array}$ \\
\hline $\begin{array}{l}\text { Proficiency } \\
\text { testing }\end{array}$ & PAT & PAT & PAT & WASP & WASP \\
\hline $\begin{array}{l}\text { Range } \\
\text { ( } \mu \text { g quartz) }\end{array}$ & $10-160$ & $30-250$ & $25-250$ & $10-1,000$ & $5-700$ \\
\hline $\begin{array}{l}\text { LOD } \\
\text { ( } \mu \text { g quartz) }\end{array}$ & 5 (estimated) & 10 (estimated) & 10 & $\begin{array}{l}\text { Varies with } \\
\text { particle size }\end{array}$ & $\begin{array}{l}\text { Varies with } \\
\text { particle size }\end{array}$ \\
\hline
\end{tabular}

See footnote at end of table.

(Continued) 
Table 7 (Continued). IR* sampling and analytical methods for crystalline silica

\begin{tabular}{clllll}
\hline \multirow{2}{*}{ Item } & \multicolumn{1}{c}{$\begin{array}{c}\text { NIOSH } \\
\text { Method 7602 }\end{array}$} & $\begin{array}{c}\text { NIOSH } \\
\text { Method 7603 }\end{array}$ & MSHA P-7 & MDHS 37 & MDHS 38 \\
\hline \multirow{2}{*}{ Precision } & $\overline{\mathrm{RSD}}<0.15$ & $\overline{\mathrm{RSD}}=0.098$ & $\mathrm{CV}=5-10 \%$ & $\mathrm{CV}=5 \%$ & $\mathrm{CV}=5 \%$ \\
& $@ 30 \mu \mathrm{g}$ & @ $100-500 \mu \mathrm{g}$ & @ $100-500 \mu \mathrm{g}$ & @ $50 \mu \mathrm{g}$ & @ $50 \mu \mathrm{g}$ \\
\hline
\end{tabular}

*Abbreviations: $\mathrm{CV}=$ coefficient of variation (equivalent to $\mathrm{RSD}$, relative standard deviation); IR = infrared absorption; $\mathrm{KBr}=$ potassium bromide; $\mathrm{MCE}=$ methyl cellulose ester; MDHS = Methods for the Determination of Hazardous Substances (Health and Safety Executive, United Kingdom); MSHA = Mine Safety and Health Administration; $\mathrm{NIOSH}=$ National Institute for Occupational Safety and Health; LOD = limit of detection; PAT = proficiency analytical testing; $\mathrm{PVC}=$ polyvinyl chloride; $\mathrm{RF}=$ radio frequency; $\overline{\mathrm{RSD}}=$ pooled relative standard deviation (equivalent to $\overline{\mathrm{CV}}$, pooled coefficient of variation); WASP $=$ Workplace Analysis Scheme for Proficiency. 
calibration of the technique has been shown to be critical in the accurate measurement of crystalline silica [Eller et al. 1999b]. Also, it is essential that only standard reference materials from the National Institute of Standards and Technology (NIST) (for which particle size and phase purity has been established) be used to prepare calibration curves for quartz (1878a) and cristobalite (1879a) [Eller et al. 1999a]. No standard reference material for tridymite is available, since this silica polymorph rarely exists in the workplace. However, a wellcharacterized sample of tridymite of the appropriate particle size is available from the U.S. Geological Survey ${ }^{*}$ and can be used as a reference standard.

Direct-on-filter techniques are used by the United Kingdom, the European Union, and Australia [Madsen et al. 1995]. These techniques require less time and labor than others and are amenable to both XRD and IR analyses [Lorberau et al. 1990]. However, direct-on-filter techniques are affected by the manner in which the particles are deposited on the filter sample (particle deposition may be nonuniform). Thus care must be taken when choosing the area of the filter to measure so that results can be compared with other methods. Sample overloading is possible for a sample collected over a full work shift.

\subsubsection{Feasibility of Measuring Crystalline Silica at Various Concentrations}

The efficacy of sampling and analytical methods for measuring concentrations of hazardous materials may be established using the NIOSH

\footnotetext{
*Tridymite reference material may be obtained from Dr. Stephen A. Wilson, U.S. Geological Survey, Box 25046, MS 973, Denver, CO 80225 (telephone: 303-236-2454; FAX: 303-236-3200; e-mail: swilson @usgs.gov; Web site: http://minerals.cr.usgs.gov/ geochem).
}

accuracy criterion [NIOSH 1995b], which requires better than $25 \%$ accuracy at concentrations of expected method application. Accuracy, as a percentage of true concentration values, is defined in terms of an interval expected to contain $95 \%$ of (future) measurements. To account for uncertainty in method evaluations, the upper $95 \%$ confidence limit on the accuracy is measured and used in the criterion. Generally, the accuracy of a method is measured over a range of concentrations bracketing the OSHA PEL. Use of a range of measurements means that accuracy is assuredboth at concentrations below the PEL (for possible use in action level determinations) and, more significantly, at the PEL (where method results must be legally defensible).

NIOSH has evaluated both the XRD silica method (NIOSH Method P\&CAM 259, the forerunner to NIOSH Method 7500) [NIOSH 1979b] and an IR silica method (MSHA Method $\mathrm{P}-7$, equivalent to NIOSH Method 7603) in a collaborative test among several laboratories [NIOSH, BOM 1983]. One result of the test was that the accuracy of the methods was estimated by evaluating the intralaboratory variability at various filter loadings. The concentrations to which these filter loadings correspond depend on the flow rate of the presampler used. Experimental conditions and results relevant to the derivation of these estimates are summarized in Tables 8 and 9. The results of the collaborative tests indicate that both the XRD and IR methods tested meet the NIOSH accuracy criterion [NIOSH 1995b] over the range of filter loadings measured. Currently, OSHA uses the 10 -mm nylon cyclone at a sampling rate of $1.7 \mathrm{~L} / \mathrm{min}$ for sampling crystalline silica. The concentrations relevant to the collaborative test conditions are listed in Tables 10 and 11 and assume an 8-hr sampling period. As indicated in Tables 10 and 11 , the traditional nylon cyclone meets the 
Table 8. Intralaboratory results for evaluation of XRD silica method

\begin{tabular}{|c|c|c|c|}
\hline \multirow[b]{2}{*}{ Item } & \multicolumn{3}{|c|}{ Filter loading } \\
\hline & $69.4 \mu \mathrm{g}$ & $98.4 \mu \mathrm{g}$ & $204 \mu \mathrm{g}$ \\
\hline Degrees of freedom & 12 & 11 & 12 \\
\hline RSD for sampling and analytical methods $(\%)^{*}, \dagger$ & 8.8 & 6.3 & 8.1 \\
\hline \multicolumn{4}{|c|}{$\begin{array}{l}\text { Source: NIOSH, BOM [1983]. } \\
\text { *RSD = relative standard deviation. RSD for sampling and analytical methods represents the RSD in } \\
\text { mass estimates, accounting for intersampler and analytical variability. } \\
{ }^{\dagger} \text { Implications for XRD: Pooled filter levels and pump error (assumed to be }<5 \% \text { ) indicate that the } \\
\text { overall imprecision is as follows: Total RSD for sampling and analytical methods is } 9.3 \% \text {. Therefore, } \\
\text { the upper } 95 \% \text { confidence limit on the accuracy ( } 35 \text { degrees of freedom) is } 21 \% \text {. }\end{array}$} \\
\hline
\end{tabular}

Table 9. Intralaboratory results for evaluation of IR silica method

\begin{tabular}{|c|c|c|c|}
\hline \multirow[b]{2}{*}{ Item } & \multicolumn{3}{|c|}{ Filter loading } \\
\hline & $67.2 \mu \mathrm{g}$ & $99.7 \mu \mathrm{g}$ & $161 \mu \mathrm{g}$ \\
\hline Degrees of freedom & 10 & 12 & 11 \\
\hline RSD for sampling and analytical methods $(\%)^{*, \dagger}$ & 5.8 & 7.8 & 7.4 \\
\hline \multicolumn{4}{|c|}{ Source: NIOSH, BOM [1983]. } \\
\hline \multicolumn{4}{|c|}{$\begin{array}{l}\text { Implications for IR: Pooled filter levels and pump error (assumed to be }<5 \% \text { ) indicate that the } \\
\text { overall imprecision is as follows: Total RSD for sampling and analytical methods is } 7.1 \% \text {. } \\
\text { Therefore, the upper } 95 \% \text { confidence limit on the accuracy ( } 33 \text { degrees of freedom) is } 17 \% \text {. }\end{array}$} \\
\hline
\end{tabular}


Table 10. XRD method evaluation: concentration ranges bracketing applicable exposure limits for which the NIOSH accuracy criterion is met*

$\left(\mu \mathrm{g} / \mathbf{m}^{3}\right)$

\begin{tabular}{ccccc}
\hline & \multicolumn{3}{c}{ Filter loading } & \\
\cline { 2 - 4 } Cyclone and sampling rate & $\mathbf{6 9 . 4} \mu \mathbf{g}$ & $\mathbf{9 8 . 4} \boldsymbol{\mu g}$ & $\mathbf{2 0 4} \boldsymbol{\mu g}$ & $\begin{array}{c}\text { Applicable } \\
\text { exposure limit }\end{array}$ \\
\hline Nylon cyclone, $1.7 \mathrm{~L} / \mathrm{min}$ & 85 & 121 & 251 & 100 \\
GK2.69 cyclone, $4.2 \mathrm{~L} / \mathrm{min}$ & 34 & 49 & 102 & 50 \\
\hline
\end{tabular}

*Eight-hour sampled masses are combined with results of NIOSH, BOM [1983].

Table 11. IR method: concentration ranges bracketing applicable exposure limits for which the NIOSH accuracy criterion is met* $\left(\mu \mathrm{g} / \mathbf{m}^{3}\right)$

\begin{tabular}{lcccc}
\hline & \multicolumn{3}{c}{ Filter loading } & \\
\cline { 2 - 4 } Cyclone and sampling rate & $\mathbf{6 . 7 2} \mu \mathbf{g}$ & $\mathbf{9 9 . 7} \boldsymbol{\mathbf { g }}$ & $\mathbf{1 6 1} \boldsymbol{\mathbf { g }}$ & $\begin{array}{c}\text { Applicable } \\
\text { exposure limit }\end{array}$ \\
\hline Nylon cyclone, $1.7 \mathrm{~L} / \mathrm{min}$ & 83 & 123 & 198 & 100 \\
GK2.69 cyclone, $4.2 \mathrm{~L} / \mathrm{min}$ & 34 & 50 & 80 & 50 \\
\hline
\end{tabular}

*Eight-hour sampled masses are combined with results of NIOSH, BOM [1983]. 
accuracy criterion over a range of concentrations bracketing $100 \mu \mathrm{g} / \mathrm{m}^{3}$.

Since the GK2.69 cyclone is expected to conform to the ISO/CEN/ACGIH respirable aerosol sampling convention, the NIOSH intralab- oratory collaborative tests can be used to establish confidence limits on its accuracy. The results of the collaborative tests indicate that the GK2.69 cyclone meets the accuracy criterion over a range of concentrations bracketing $50 \mu \mathrm{g} / \mathrm{m}^{3}$, as illustrated in Tables 10 and 11 . 


\section{Human Health Effects}

\subsection{Epidemiologic Considerations in Occupational Respiratory Disease Studies}

\subsubsection{Study Designs}

Epidemiology is the study of patterns of disease occurrence in human populations and the factors that influence those patterns [Lilienfeld and Stolley 1994]. Epidemiology is the primary science used to study silica-related diseases in workers. Most epidemiologic studies of silica-exposed workers discussed in this review are cross-sectional studies (i.e., prevalence studies) or retrospective (i.e., historical) cohort studies. Cross-sectional studies measure symptom or disease occurrence in a selected population at one point in time. An example of a cross-sectional study design would be the spirometric testing of lung function in a group of granite shed workers during an annual health survey and comparison with respiratory function in nongranite workers. Crosssectional studies have two disadvantages:

- Usually only the "survivor" population is examined. Retired, former, or deceased workers are not included, possibly resulting in an underestimate of the disease prevalence.

- It may be impossible to determine whether exposure preceded the disease if both are measured at the same time.

Many epidemiologic studies of silica-related diseases are retrospective cohort morbidity or mortality studies. In this approach, the illnesses, deaths, and exposures (surrogate or reconstructed) of an entire cohort (e.g., all workers ever employed in one foundry) are followed forward from a time in the past to a

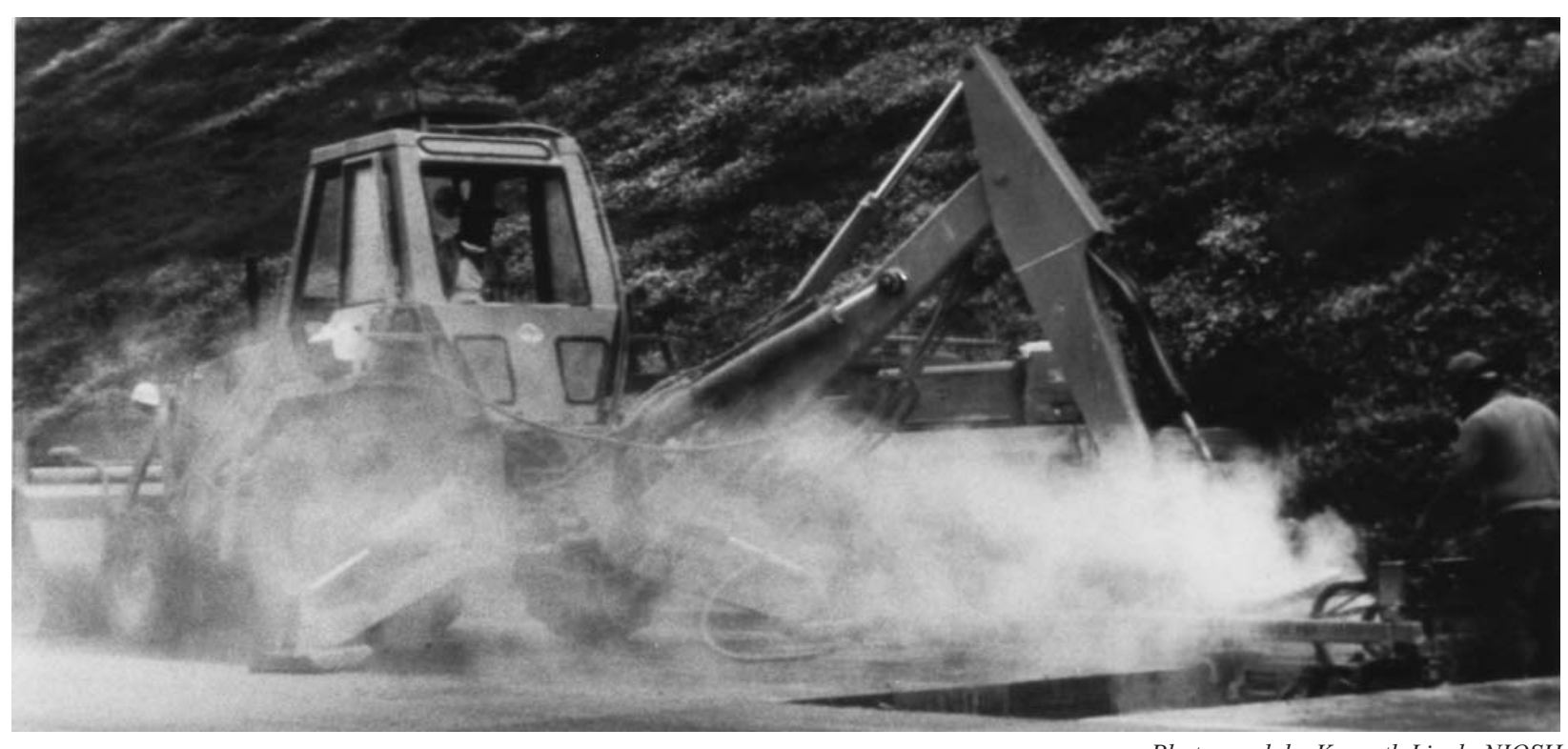

Construction workers drilling holes in concrete pavement during highway repair.

Photograph by Kenneth Linch, NIOSH 
designated time in the future, and the number and causes of deaths that occur in that interval are assessed. Exposures for the followup period may be reconstructed from historical information or a surrogate measure such as duration of employment. The mortality of the cohort is then compared with the mortality of a standard population. For example, Steenland and Brown [1995b] used a retrospective study design to examine the mortality of a cohort of white male underground gold miners employed for at least 1 year between 1940 and 1965. The miners were followed from their first date of mining employment to their date of death or until the end of 1990, whichever came first. Their mortality was then compared with that of the U.S. population or the county where the mine was located. A disadvantage of silicosis mortality studies that use death certificate data is that silicosis cases could be underascertained even when contributing causes of death are included, as suggested by a study of silicosis mortality surveillance in the United States [Bang et al. 1995].

\subsubsection{Sources of Bias}

Three main (but not mutually exclusive) types of bias may affect the results of epidemiologic studies of silica-exposed workers-selection bias, information bias, and confounding [Checkoway 1995]:

- Selection bias originates from the method of choosing study subjects. This type of bias is a common criticism of lung cancer studies of compensated silicotics because silicotic workers who sought compensation for their disease may differ from all silicotics in symptoms, radiographic changes, social and psychological factors, and industry [Weill and McDonald 1996; McDonald 1995]. However, Goldsmith [1998] reviewed this question and concluded that lung cancer risk estimates were not higher in compensated silicotics when compared with those of silicotics ascertained from other clinical sources (i.e., hospital or registry data).

- Information bias involves misclassification of study subjects by disease or exposure status [Checkoway et al. 1989]. An example of disease (silicosis) misclassification occurred in a study of North Carolina dusty trades workers [Amandus et al. 1991; Rice et al. 1986]: a re-evaluation of the chest $\mathrm{X}$-rays found that 104 of the 370 cases categorized as silicosis were actually International Labour Organization (ILO) category 0 (nonsilicotic) [Amandus et al. 1992]. Sources of exposure assessment errors include instrument error, incorrect imputation of exposure when data are missing, and data extrapolation errors [Checkoway 1995]. Misclassification of exposure may occur in retrospective cohort studies of silicosis when quantitative dust exposure measurements are mathematically converted from particle counts to gravimetric respirable silica equivalents.

- Confounding variables are factors that are related to exposure and are also independent risk factors for the disease under study [Checkoway 1995]. Most studies of silica-related diseases controlled for confounding factors such as age and race by study design or data analysis. Confounding from cigarette smoking is an important concern in studies of lung cancer, bronchitis, asthma, emphysema, chronic obstructive pulmonary disease (COPD), and lung function. Confounding of an exposure-disease relationship by cigarette smoking is less likely when an internal comparison group is usede.g., when both groups are from the same plant [Siemiatycki et al. 1988]. 
(Some studies in this review used external comparison populations.) Most of the lung cancer studies among underground miners did not control for the effects of other carcinogens that may have been present, such as arsenic, radon progeny, and diesel exhaust (see Section 3.4.1).

The effects of bias discussed here can be minimized by applying epidemiologic methods. Description of appropriate methodology is available in epidemiology textbooks.

\subsection{Silicosis}

\subsubsection{Definition}

Silicosis most commonly occurs as a diffuse nodular pulmonary fibrosis. This lung disease (which is sometimes asymptomatic [NIOSH 1996b]) is caused by the inhalation and deposition of respirable crystalline silica particles (i.e., particles $<10 \mu \mathrm{m}$ in diameter) [Ziskind et al. 1976; IARC 1987]. According to a report from the U.S. Surgeon General [DHHS 1985], cigarette smoking has "no significant causal role" in the etiology of silicosis. Probably the most important factor in the development of silicosis is the "dose" of respirable silicacontaining dust in the workplace setting - that is, the product of the concentration of dust containing respirable silica in workplace air and the percentage of respirable silica in the total dust. Other important factors are (1) the particle size, (2) the crystalline or noncrystalline nature of the silica, (3) the duration of the dust exposure, and (4) the varying time period from first exposure to diagnosis (from several months to more than 30 years) [Banks 1996; Kreiss and Zhen 1996; Hnizdo and Sluis-Cremer 1993; Hnizdo et al. 1993; Steenland and Brown 1995a; ATS 1997]. Experimental evidence supporting the influence of these factors has recently been reviewed [Mossman and Churg 1998; Heppleston 1994]. Many in vitro studies have been conducted to investigate the surface characteristics of crystalline silica particles and their influence on fibrogenic activity [Bolsaitis and Wallace 1996; Fubini 1997, 1998; Castranova et al. 1996; Donaldson and Borm 1998; Erdogdu and Hasirci 1998]. These researchers found that a number of features may be related to silica cytotoxicity. Further research is needed to associate the surface characteristics with occupational exposure situations and health effects [Donaldson and Borm 1998]. Such exposure situations may include work processes that produce freshly fractured silica surfaces [Bolsaitis and Wallace 1996; Vallyathan et al. 1995] or that involve quartz contaminated with trace elements such as iron [Castranova et al. 1997].

A worker may develop one of three types of silicosis, depending on the airborne concentration of respirable crystalline silica: (1) chronic silicosis, which usually occurs after 10 or more years of exposure at relatively low concentrations; (2) accelerated silicosis, which develops 5 to 10 years after the first exposure; or (3) acute silicosis, which develops after exposure to high concentrations of respirable crystalline silica and results in symptoms within a period ranging from a few weeks to 5 years after the initial exposure [NIOSH 1996b; Parker and Wagner 1998; Ziskind et al. 1976; Peters 1986]. The symptoms of accelerated silicosis are similar to those of chronic silicosis, but clinical and radiographic progression is rapid. Also, fibrosis may be irregular and more diffuse [Banks 1996; Seaton 1995; Silicosis and Silicate Disease Committee 1988] or not apparent on the chest radiograph [Abraham and Weisenfeld 1997]. Acute silicosis is typically associated with a history of high exposures from tasks that produce small particles of airborne dust with a high silica content, such as sandblasting, rock drilling, or quartz milling [Davis 1996]. The pathologic characteristics of acute silicosis (sometimes referred to as silicoproteinosis) resemble those of alveolar proteinosis [Wagner 1994; Davis 1996]. 
Pulmonary fibrosis may not be present in acute silicosis [NIOSH 1996b].

Epidemiologic studies of gold miners in South Africa, granite quarry workers in Hong Kong, metal miners in Colorado, and coal miners in Scotland have shown that chronic silicosis may develop or progress even after occupational exposure to silica has been discontinued [Hessel et al. 1988; Hnizdo and Sluis-Cremer 1993; Hnizdo and Murray 1998; Ng et al. 1987; Kreiss and Zhen 1996; Miller et al. 1998]. Therefore, removing a worker from exposure after diagnosis does not guarantee that silicosis or silica-related disease will stop progressing or that an impaired worker's condition will stabilize [Parker and Wagner 1998; Weber and Banks 1994; Wagner 1994].

\subsubsection{Epidemiologic Exposure-Response Models of Silicosis}

This section reviews published epidemiologic studies that provide evidence of an exposureresponse relationship for crystalline silica and silicosis using cumulative exposure data. Exposure-response models based on cumulative exposure data can predict silicosis risk for a particular silica dust exposure over a period of time. Epidemiologic studies that provided evidence of an exposure-response relationship for silica and silicosis on the basis of other kinds of exposure data (e.g., duration of exposure) have been reviewed elsewhere [EPA 1996; Davis 1996; Hughes 1995; Rice and Stayner 1995; Seaton 1995; Steenland and Brown 1995a; Goldsmith 1994a; WHO 1986].

Table 12 summarizes the published studies that predict the incidence or prevalence of radiographic silicosis based on models of cumulative exposure to respirable crystalline silica. Table 13 presents details about the cohorts, quartz content of the dust, followup periods, and limitations of each study. All of the studies predicted the occurrence of at least one case of radiographic silicosis per 100 workers at cumulative exposures approximately equal to the OSHA and MSHA PELs and the NIOSH REL over a 40- or 45-year working lifetime (see appendix for the PELs and REL). Three studies predicted prevalences of $47 \%$ to 95\% at the OSHA PEL. Each study followed a cohort of miners for at least three decades from first employment in the industry [Kreiss and Zhen 1996; Hnizdo and Sluis-Cremer 1993; Steenland and Brown 1995a]. Studies of foundry workers [Rosenman et al. 1996], hardrock miners [Muir et al. 1989a,b; Muir 1991], and workers in the diatomaceous earth industry [Hughes et al. 1998] followed workers for less than 30 years (mean) and predicted prevalences of $1 \%$ to $3 \%$. The studies presented in Table 12 predicted that approximately 1 to 7 silicosis cases per 100 workers would occur at respirable quartz concentrations of $0.025 \mathrm{mg} / \mathrm{m}^{3}$ - half the NIOSH REL of $0.05 \mathrm{mg} / \mathrm{m}^{3}$ - with the contingencies and exceptions noted in Table 12. However, that concentration cannot be measured accurately at this time for the reasons given in Section 2.4.

Table 12 does not include a cohort study of 1,416 coal miners exposed to coal dust with quartz concentrations ranging from $0.4 \%$ to $29.4 \%$ of respirable dust [Miller et al. 1998]. This study predicted pneumoconiosis risks for 47 men with a "profusion of median small opacities" of ILO category $\geq 2 / 1$ (i.e., $2 / 1+$ ), a higher category of radiographic abnormality than reported in the studies listed in Tables 12 and 13. Logistic regression models predicted that the risk of small opacities of $2 / 1+$ at the time of followup examination would be about $5 \%$ for miners exposed to a mean respirable quartz concentration of $0.1 \mathrm{mg} / \mathrm{m}^{3}$ and about $2 \%$ for miners exposed to a mean respirable quartz concentration of $0.05 \mathrm{mg} / \mathrm{m}^{3}$ for about 15 years [Miller et al. 1998]. The predicted risks increased with cumulative exposure to respirable quartz dust. 


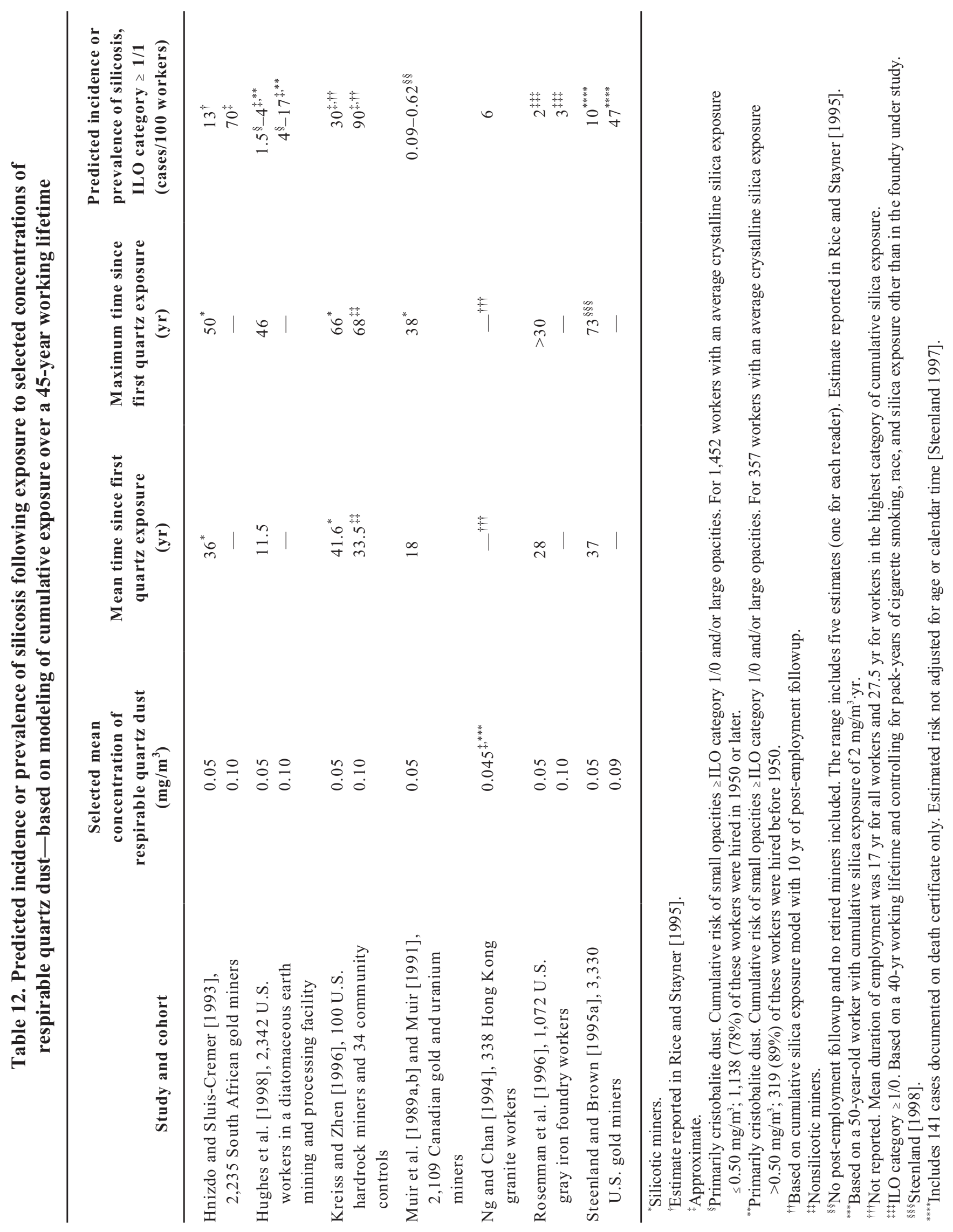




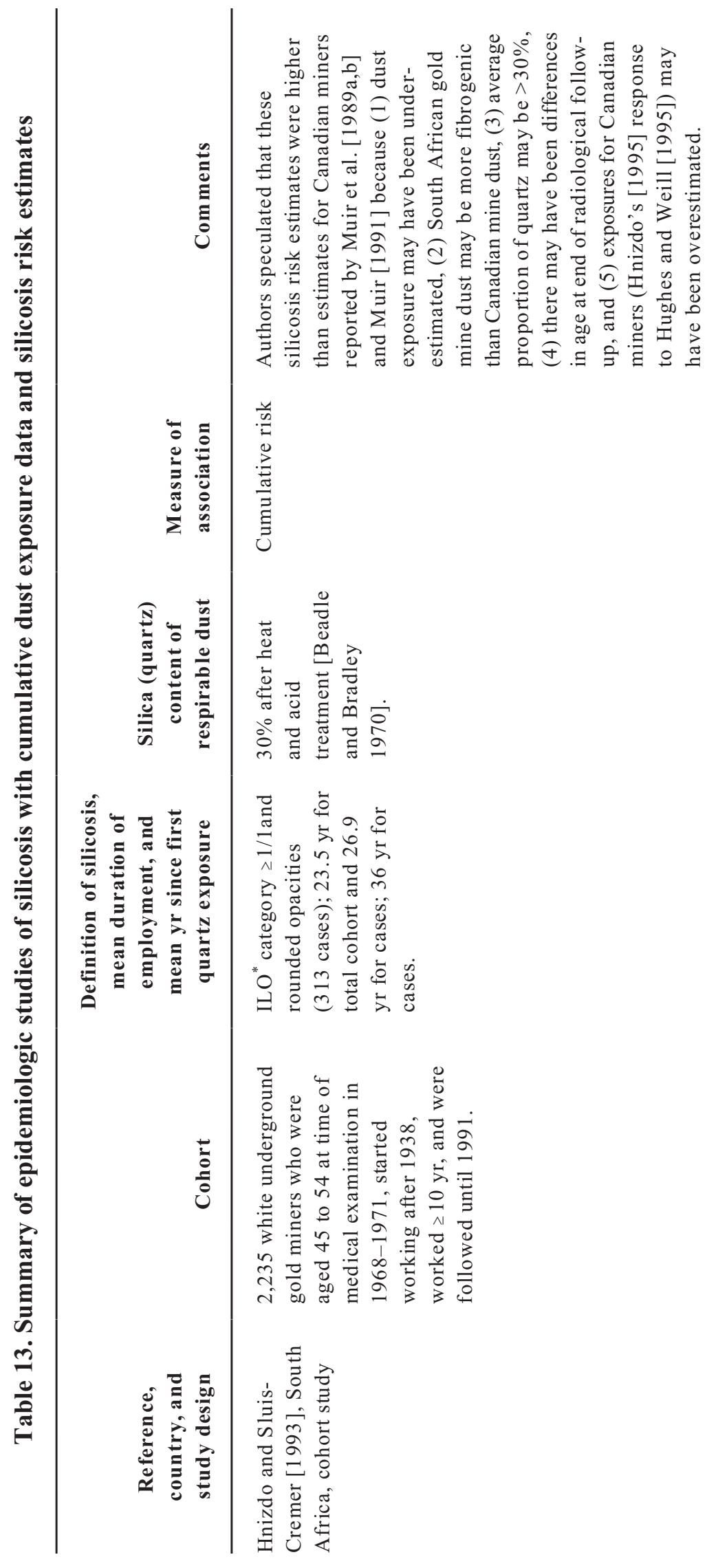




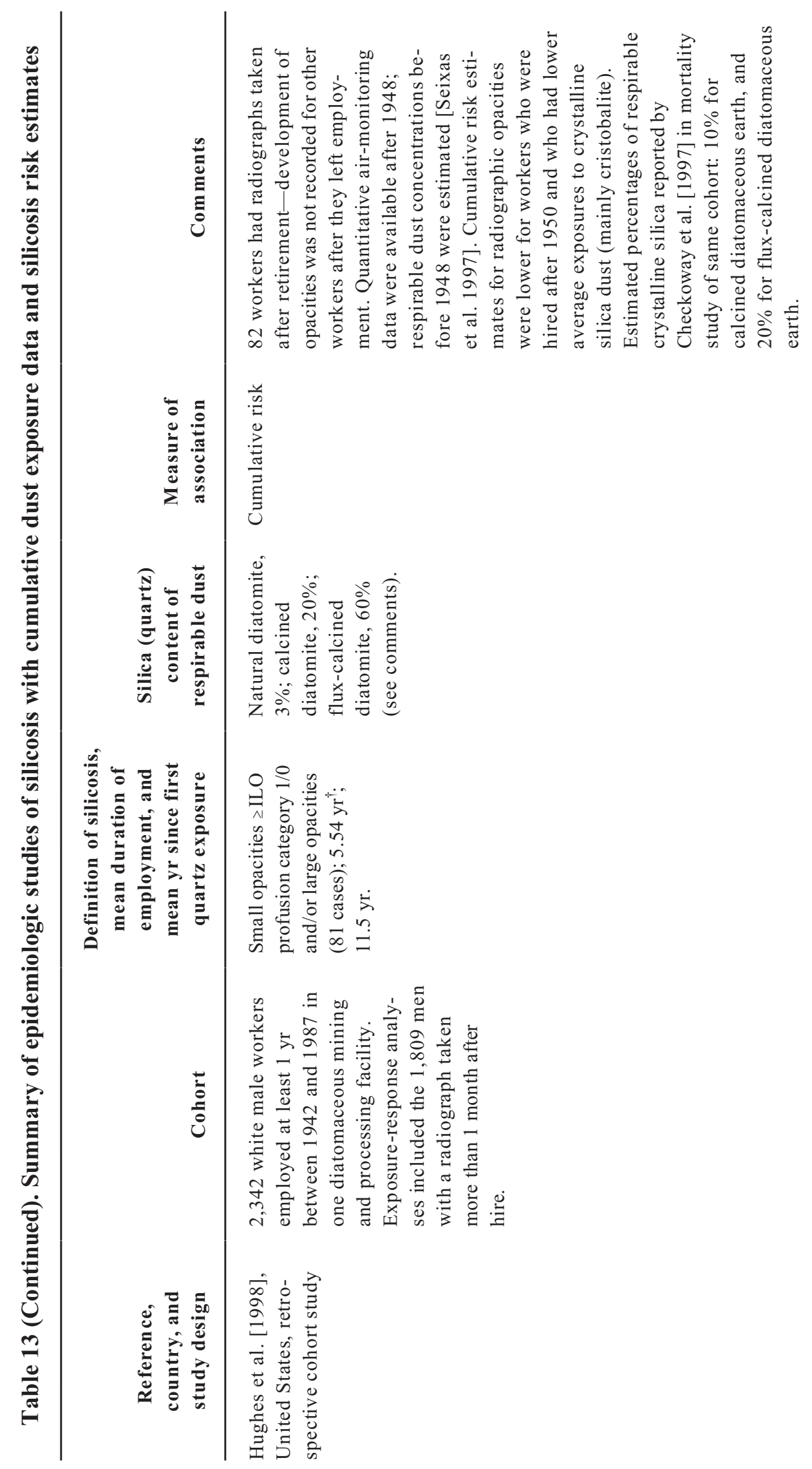




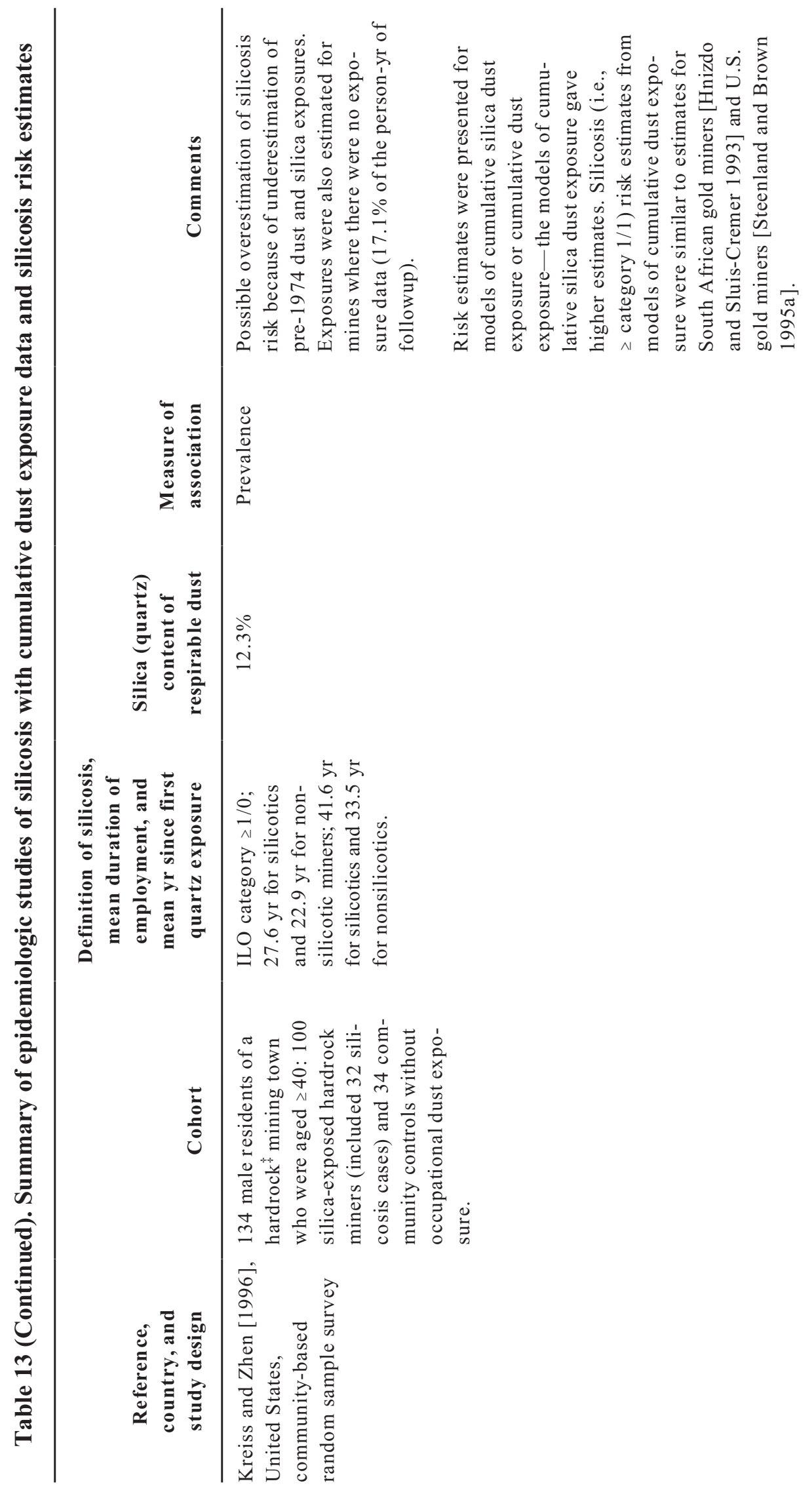




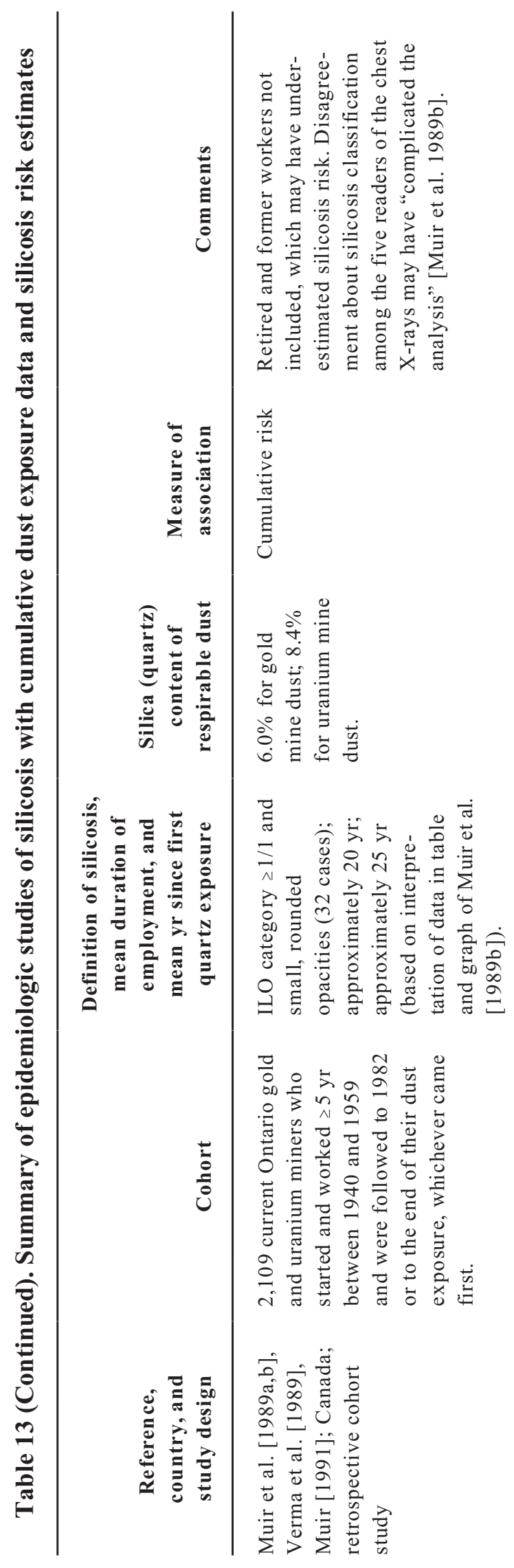




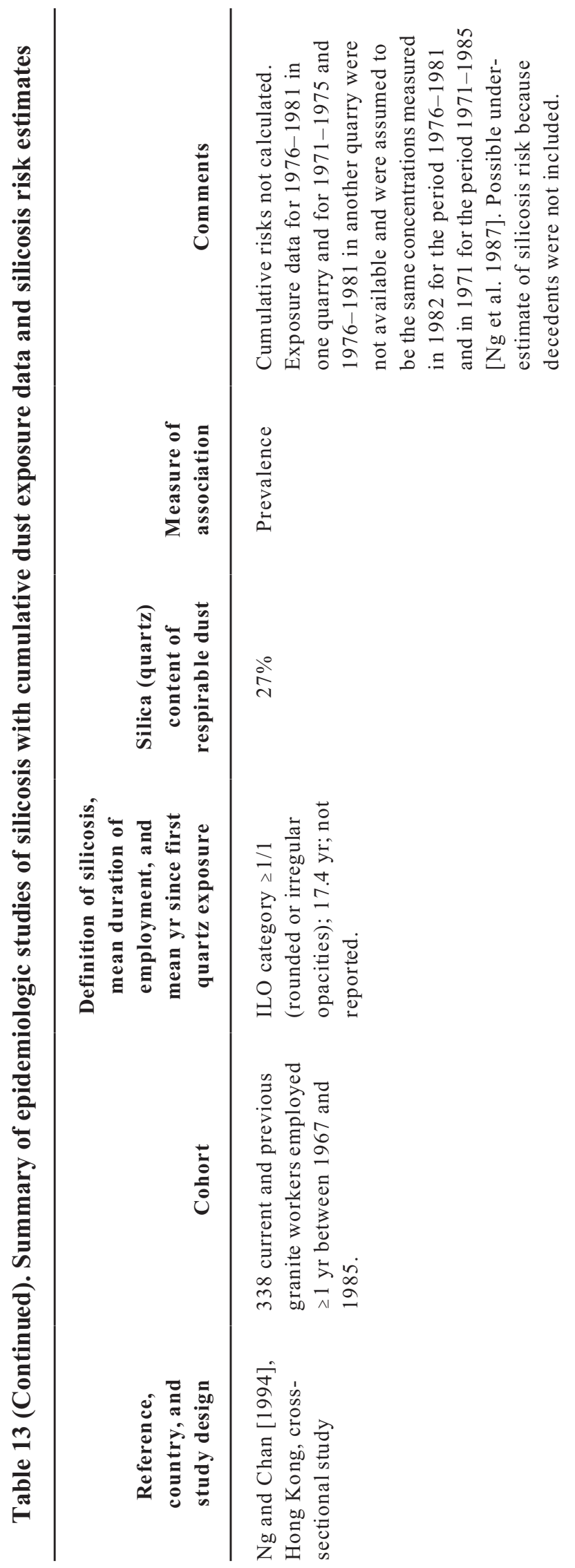




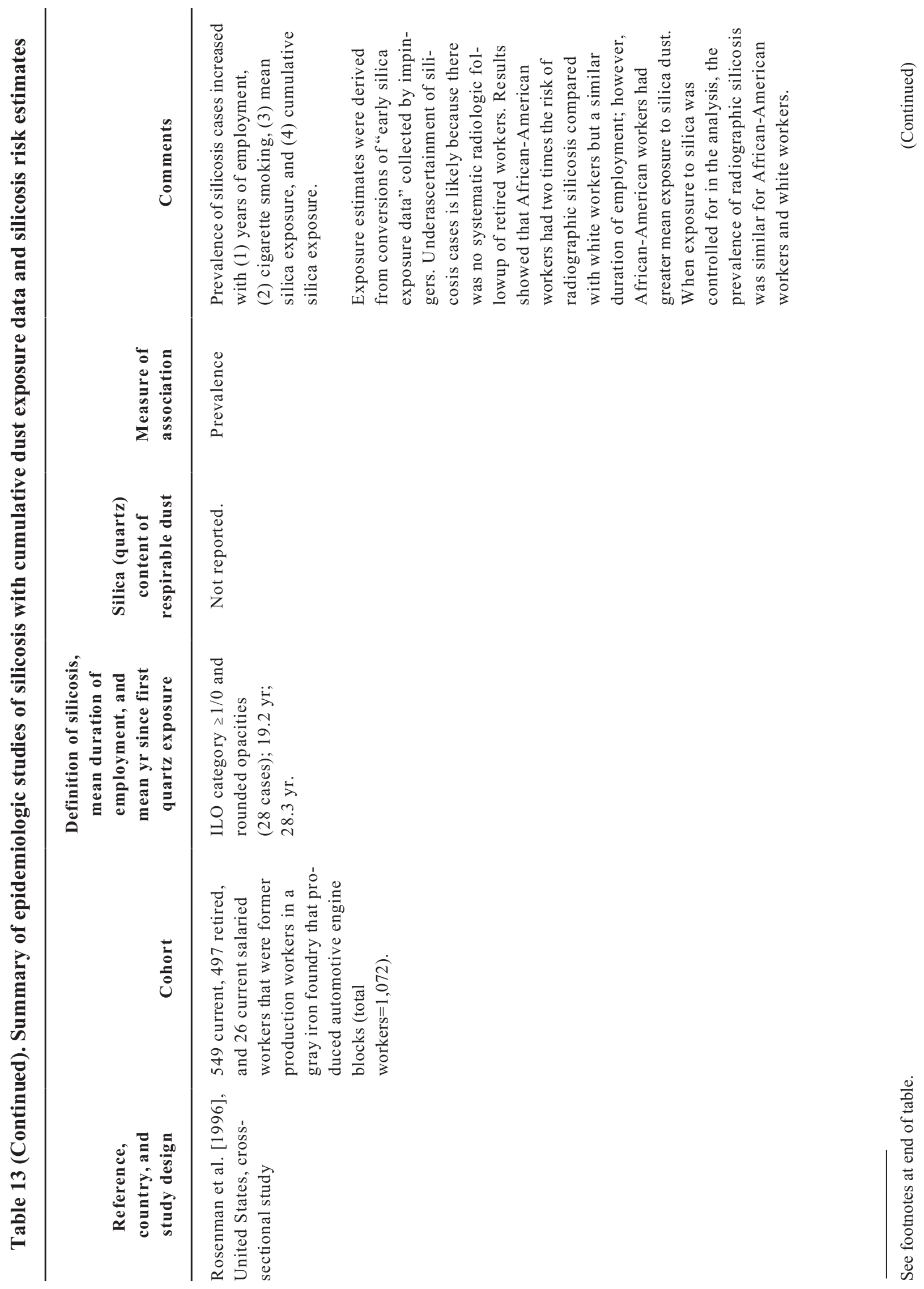




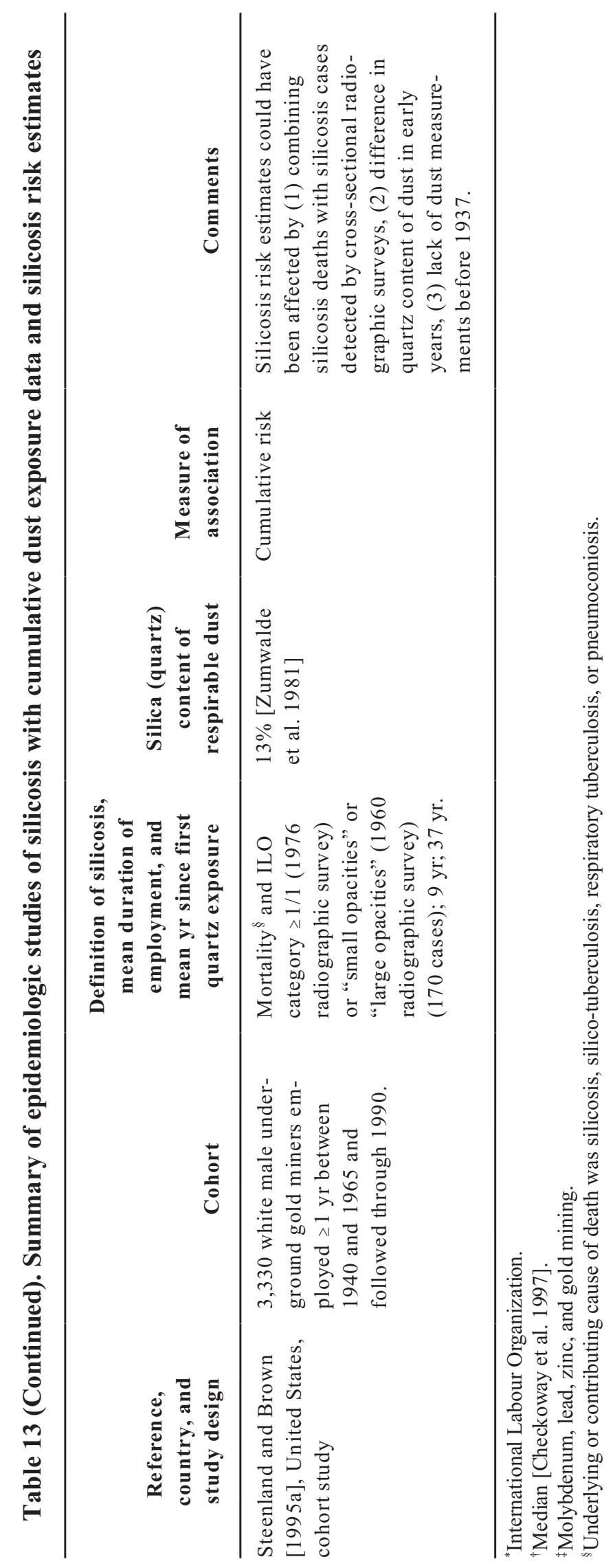


A currently unpublished study of 600 retired Vermont granite workers found nodular opacities consistent with silicosis (degrees of profusion not reported in abstract) in $4.7 \%$ of 360 radiographs read by three readers [Graham et al. 1998]. The average duration of employment for these workers was 31 years, and the average time from first exposure to radiographic examination was 39 years. Most workers in the cohort were first employed after 1940, when average quartz dust concentrations were below the current OSHA PEL [Graham et al. 1991; Ashe and Bergstrom 1964].

Although the variability in prevalence estimates (i.e., $1 \%$ to $90 \%$ ) cannot be solely attributed to differences in followup periods, chronic silicosis is a progressive disease, and its development after a long latency period and after workers leave employment must be accounted for in epidemiologic studies. A study of autopsied gold miners in South Africa also supports the need for examining workers after a long latency period and after they leave employment [Hnizdo et al. 1993]. Radiologic findings for profusion of rounded opacities (ILO category $\geq 1 / 1$ ) were compared with pathological findings for silicosis in 326 miners with an average of 2.7 years between the radiologic and pathologic examinations. Silicosis was not diagnosed radiographically for at least $61 \%$ of the miners with slight to marked silicosis at autopsy. The probability of a false negative reading increased with years of mining and average concentration of respirable dust [Hnizdo et al. 1993]. Experimental studies of rats also reported a lack of complete agreement between histopathologic indicators of silica dust exposure and radiographic readings [Drew and Kutzman 1984a,b].

In addition, improved exposure assessment methods and data analyses that account for variations and deficiencies in exposure data would improve the risk estimates for silicaexposed workers [Agius et al. 1992; Checkoway
1995]. Although epidemiologic studies that used cumulative exposure estimates represent the best available source of information for characterizing the dose-response relationship in occupational cohorts, peak exposures may predict silicosis risk better than cumulative exposures [Checkoway and Rice 1992]. However, data on peak exposures are rarely available, and data supporting this hypothesis are limited.

\subsection{TB and Other Infections}

\subsubsection{Definition}

As silicosis progresses, it may be complicated by severe mycobacterial or fungal infections [NIOSH 1996b; Ziskind et al. 1976; Parkes 1982; Parker 1994]. The most common of these infections, TB, occurs when the macrophages are overwhelmed by silica dust and are unable to kill the infectious organism $\mathrm{Myco}$ bacterium tuberculosis [Parker 1994; $\mathrm{Ng}$ and Chan 1991; NIOSH 1992a,b; Allison and Hart 1968]. About half of the mycobacterial infections that occur in workers with exposure to silica are caused by M. tuberculosis, and the other half are caused by the nontuberculous mycobacteria (NTM) Mycobacterium kansasii and Mycobacterium avium-intracellulare [Owens et al. 1988; NIOSH 1996b]. Infections in workers with silicosis may also be caused by Nocardia asteroides and Cryptococcus [Ziskind et al. 1976; NIOSH 1996b; Parker 1994; Parker and Wagner 1998]. ATS [1997] recommends that the diagnostic investigation of a patient with silicosis and possible TB include consideration of NTM disease. The ATS also recommends that tuberculin tests be administered to persons with silicosis and to those without silicosis who have at least 25 years of occupational exposure to crystalline silica [ATS 1997].

\subsubsection{Epidemiologic Studies}

Recent surveillance data indicate that TB rates in the United States are 5 to 10 times higher 
among racial and ethnic minorities (after adjustment for the effects of age, sex, and country of birth) [Cantwell et al. 1998]. Cantwell et al. [1998] reported that the relative risk of TB increased as socioeconomic status (measured by six indicators) decreased, after adjustment for the effects of age (relative risks ranged from 2.6 to 5.6 in the lowest versus highest quartiles). The number of TB cases among foreign-born persons in the United States increased by $56 \%$ during the period 1986 to 1997 [CDC 1998c].

The association between TB and silicosis has been firmly established by the results of epidemiologic studies conducted during this century [Balmes 1990]. This association was supported by a survey of TB deaths among silicotics in the United States for the period 1979 to 1991 [Althouse et al. 1995] and by the results of four recent epidemiologic studies [Goldsmith et al. 1995; Cowie 1994; Sherson and Lander 1990; Kleinschmidt and Churchyard 1997]. Black South African gold miners [Cowie 1994] and Danish foundry workers [Sherson and Lander 1990] with chronic silicosis had threefold and tenfold incidences of $\mathrm{TB}$, respectively, compared with nonsilicotic, non-silica-exposed workers of similar age and race. Goldsmith et al. [1995] compared the mortality of 590 California silicosis claimants with that of U.S. males and found that the TB mortality of the claimants was 50 times that of all U.S. males (standardized mortality ratio $[\mathrm{SMR}]=56.35 ; 45$ deaths observed, 0.8 expected; $95 \%$ confidence interval $[\mathrm{CI}]=41.10-75.40)$. A retrospective study of $\mathrm{TB}$ among 4,976 miners from the Freegold mines in South Africa reported that the incidence rate ratio for miners with silicosis (ILO category $\geq 1 / 1$ ) was 1.54 (95\% CI $=1.00-2.37)$ compared with miners without silicosis (after adjusting for the effects of age, followup period, cumulative service, and occupation) [Kleinschmidt and Churchyard 1997]. The incidence of TB for the oldest age group was 21 times that of the youngest group (incidence rate ratio $=21.17$;
$95 \% \mathrm{CI}=8.60-52.11)$; and for workers in occupations with high dust exposure (such as drilling), the incidence was twice that of surface and maintenance workers (adjusted incidence rate ratio $=2.25 ; 95 \% \mathrm{CI}=1.49-3.38$ ) [Kleinschmidt and Churchyard 1997].

Some evidence indicates that workers who do not have silicosis but who have had long exposures to silica dust may be at increased risk of developing TB. Two epidemiologic studies reported that, compared with the general population, a threefold incidence of TB cases occurred among 5,424 nonsilicotic, silicaexposed Danish foundry workers employed 25 or more years [Sherson and Lander 1990], and nearly a tenfold incidence occurred among 335 nonsilicotic, black South African gold miners with a median underground employment of 26 years [Cowie 1994].

Westerholm et al. [1986] found 13 cases among 428 silicotic Swedish iron and steel workers and 1 case in a comparison group of 476 Swedish iron and steel workers with normal chest radiographs (level of statistical significance not reported). Both groups had been exposed to silica for at least 5 years.

A study of TB incidence in 2,255 white South African gold miners included 1,296 miners who had an autopsy [Hnizdo and Murray 1998, 1999]. The smoking-adjusted relative risk for TB in miners without silicotic nodules on autopsy examination $(n=577)$ increased slightly with quartiles of cumulative dust exposure (relative risk $=1.38[95 \% \mathrm{CI}=0.33-5.62]$ for the highest quartile of cumulative exposure). For miners without radiologically diagnosed silicosis $(n=1,934)$, the smoking-adjusted relative risk increased to $4.01(95 \% \mathrm{CI}=2.04-7.88)$ in the highest quartile of cumulative dust exposure [Hnizdo and Murray 1998, 1999]. The authors defined radiologic silicosis as ILO category $\geq 1 / 1$. TB was diagnosed, on the average, 7.6 years after the end of dust exposure and 
6.8 years after the onset of radiological silicosis - a result that supports the need for medical surveillance of workers after the end of exposure to silica dust [Hnizdo and Murray 1998]. Miners who developed TB before completing 10 years of underground employment were excluded because they were not allowed to continue working underground after diagnosis.

Corbett et al. [1999] conducted a recent casecontrol study of TB and pulmonary disease caused by NTM in South African gold miners. These researchers found that radiographic silicosis, focal radiological scarring, and human immunodeficiency virus (HIV) infection were significant risk factors for NTM disease and for TB. Past medical history of TB treatment (odds ratio $[\mathrm{OR}]=15.1 ; 95 \% \mathrm{CI}=7.64-29.93$ ) and current employment in a "dusty job" at the mines $(\mathrm{OR}=2.5 ; 95 \% \mathrm{CI}=1.46-4.44)$ were significant risk factors for NTM. ORs for NTM and TB increased with years of employment (range of ORs was 1.0 to 9.4 for NTM and 1.0 to 4.1 for TB). The study included 206 NTM patients and 381 TB patients of known HIV status admitted to a South African hospital. Also included were 180 controls who were HIV-tested surgical or trauma patients admitted to the same hospital during the same period.

Two recent studies about silica exposure and TB used U.S. occupational mortality data to conduct a proportionate mortality study of persons with TB by occupation for 1979 through 1990 [CDC 1995; Chen et al. 1997]. Although the study design did not control for confounding, it identified six occupational groups with potential exposure to silica dust that had age-adjusted proportionate mortality ratios (PMRs) for TB that were statistically significant (lower bound of the 95\% CI $>100$ ) or greater than 200. Table 14 shows significant PMRs by race for construction occupations, mining machine operators, grinding and polishing machine operators, furnace and kiln operators, laborers, and mixing and blending machine operators [CDC 1995].

Chen et al. [1997] conducted a case-control study (8,740 cases; 83,338 controls) with U.S. National Occupational Mortality Surveillance (NOMS) data for 1983-1992. The study controlled for confounding from age, sex, race, socioeconomic status, potential exposure to active TB, and the presence of silicosis and other pneumoconioses. The potential for silica exposure was based on data from NOES [NIOSH 1988] and the National Occupational Health Survey of Mining (NOHSM) [NIOSH 1996c]. This potential was categorized as "high," "intermediate," or "low or no." The study found that decedents with high potential for exposure to silica and no documentation of silicosis on the death certificate had a $30 \%$ greater odds of mortality from respiratory TB than decedents with no potential exposure to silica after adjustment by logistic regression for the possible confounders mentioned earlier $(\mathrm{OR}=1.3$; $95 \% \mathrm{CI}=1.14-1.48)$. The results also suggest an exposure-response relationship between silica exposure (in the absence of silicosis) and death from respiratory tuberculosis [Chen et al. 1997].

\subsection{Cancer}

\subsubsection{Background}

The possible carcinogenicity of crystalline silica dust became a subject of considerable and intense debate in the scientific community in the 1980 s, especially after (1) publication of new information presented at a 1984 symposium in North Carolina [Goldsmith et al. 1986], (2) epidemiologic studies by Westerholm [1980] and Finkelstein et al. [1982], and (3) a literature review by Goldsmith et al. [1982] (see McDonald [1989, 1995] and Graham [1998]). Many epidemiologic studies of cancer mortality and morbidity in silicaexposed occupational groups were published 


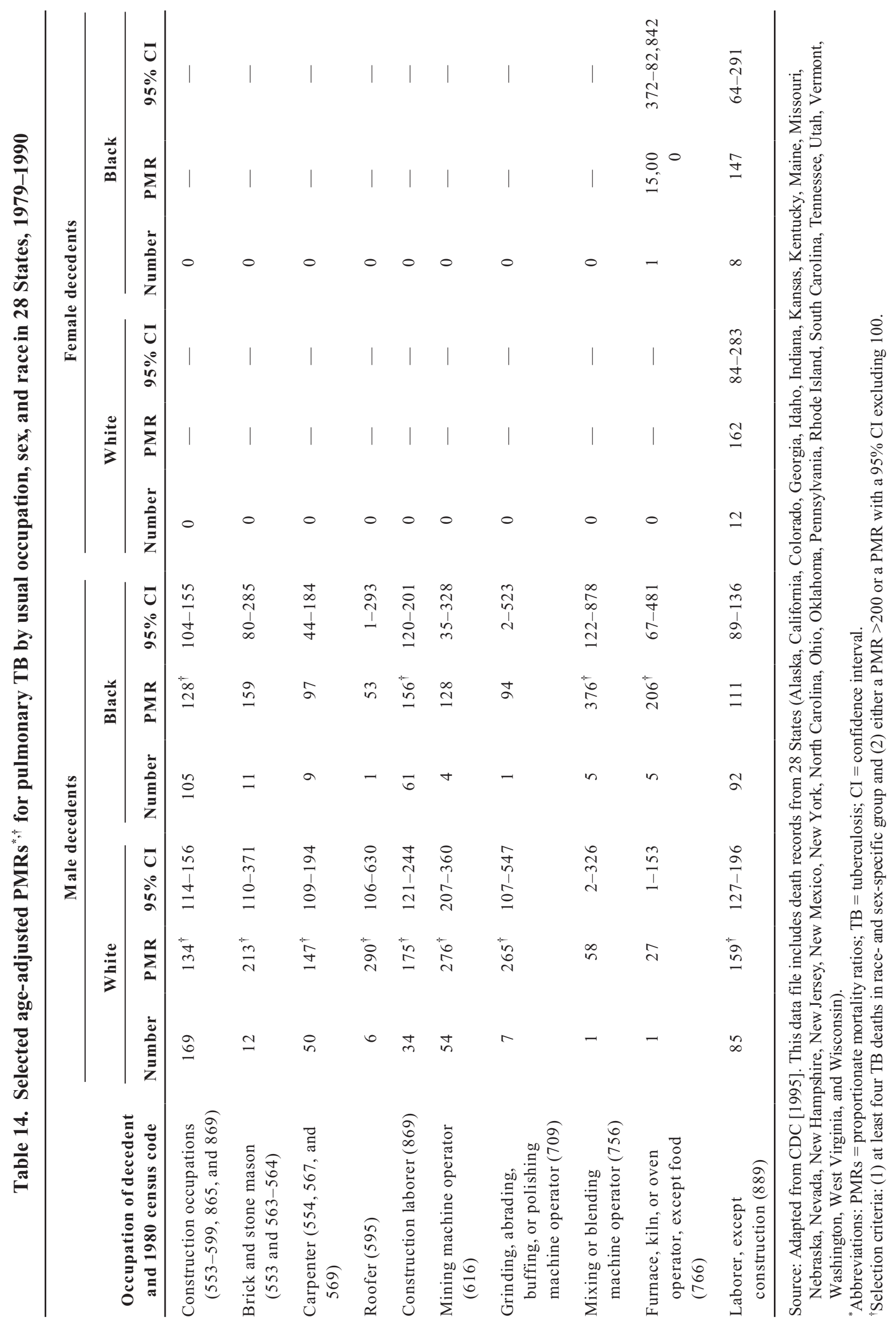


later, but the issue remained unresolved. In October 1996, an IARC expert working group reviewed the published experimental and epidemiologic studies of cancer in animals and workers exposed to respirable crystalline silica. The working group concluded that there is "sufficient evidence in humans for the carcinogenicity of inhaled crystalline silica in the form of quartz or cristobalite from occupational sources" [IARC 1997]. In June 1996, the directors of the ATS adopted an official statement of their Committee of the Scientific Assembly on Environmental and Occupational Health. This statement, prepared at the request of the American Lung Association Occupational Health Expert Advisory Group [ATS 1997], described the adverse health effects of exposure to crystalline silica, including lung cancer. The ATS found the following:

- The available data support the conclusion that silicosis produces increased risk for bronchogenic carcinoma.

- However, less information is available for lung cancer risk among silicotics who never smoked and workers who were exposed to silica but did not have silicosis.

- Whether silica exposure is associated with lung cancer in the absence of silicosis is less clear.

NIOSH concurs with the conclusions of the IARC working group and the ATS. These conclusions agree with NIOSH testimony to OSHA, in which NIOSH recommended that crystalline silica be considered a potentional occupational carcinogen [54 Fed. Reg. 2521 (1989)].

This section, like the IARC review, focuses on lung cancer and discusses the epidemiologic studies that were the least likely to have results affected by confounding and selection biases.
In "mixed" environments such as ceramics, pottery, or brick manufacturing, where exposure may be to two or more polymorphs of crystalline silica, epidemiologic studies have usually not identified specific exposures to quartz or cristobalite. Therefore, excess lung cancers that occurred in these environments cannot be associated with exposure to a given polymorph but only with exposure to respirable crystalline silica. The epidemiologic studies of cancer have mainly investigated workers exposed to respirable crystalline silica in (1) ore mining, (2) quarrying and granite works, (3) ceramics, pottery, glass, refractory brick, and diatomaceous earth industries, or (4) foundries. The other major study group was workers with silicosis, usually identified from national or local registries. Studies of workers and silicotics that were not discussed in this document because they failed to meet the "least confounded" criterion have been criticized for the following reasons [Checkoway 1995; McDonald 1995, 1996; Morgan and Reger 1995; Weill and McDonald 1996; Seaton 1995; Weill et al. 1994; Agius et al. 1992]:

- Inadequate, incomplete, or invalid exposure assessment

- Potential selection and confounding biases in the cohort studies of compensated silicotics

- Inadequate control of confounding from cigarette smoking and from concurrent workplace exposures (e.g., potential exposure to radon progeny, arsenic, or diesel exhaust in ore mines and potential exposure to polycyclic aromatic hydrocarbons in foundries)

- Inability to distinguish differences in fibrogenic and carcinogenic potencies of the various silica polymorphs

- Lack of evidence of an exposureresponse relationship 


\subsubsection{Epidemiologic Studies of Lung Cancer}

Following a comprehensive review of the large body of published epidemiologic studies, IARC [1997] found that the following studies provide the least confounded investigations of an association between occupational exposure to crystalline silica and lung cancer:

1. U.S. gold miners [Steenland and Brown 1995b]

2. Danish stone industry workers [Guénel et al. 1989]

3. U.S. granite shed and quarry workers [Costello and Graham 1988]

4. U.S. crushed stone industry workers [Costello et al. 1995]

5. U.S. diatomaceous earth industry workers [Checkoway et al. 1993, 1996]

6. Chinese refractory brick workers [Dong et al. 1995]

7. Italian refractory brick workers [Merlo et al. 1991; Puntoni et al. 1988]

8. U.K. pottery workers [McDonald et al. 1995,1997; Cherry et al. 1995,1997; Burgess et al. 1997]

9. Chinese pottery workers [McLaughlin et al. 1992]

10. Cohorts of registered silicotics from North Carolina [Amandus et al. 1991,1992] and Finland [Kurppa et al. 1986; Partanen et al. 1994]

Although a few of these studies did not find a statistically significant association between occupational exposure to crystalline silica and lung cancer (Table 15), most of the studies did.
Study results are often not uniform when a large number of epidemiologic studies are reviewed and a variety of populations and work environments are studied [IARC 1997]. In addition, IARC noted that the carcinogenicity of quartz or cristobalite "may be dependent on inherent characteristics of the crystalline silica or on external factors affecting its biological activity or distribution of its polymorphs" [IARC 1997].

Some of the least confounded studies reported that lung cancer risk tended to increase with

- cumulative exposure to respirable silica [i.e., Checkoway et al. 1993, 1996],

- duration of exposure [i.e., Merlo et al. 1991; Partanen et al. 1994; Costello and Graham 1988; Costello et al. 1995; Dong et al. 1995],

- peak intensity of exposure [Burgess et al. 1997; Cherry et al. 1997; McDonald et al. 1997],

- the presence of radiographically defined silicosis [Amandus et al. 1992; Dong et al.1995], and

- length of followup time from date of silicosis diagnosis [Partanen et al. 1994] (see Table 15).

These observed associations, including the exposure-response associations, are unlikely to be explained by confounding or other biases. Thus overall, the epidemiologic studies support increased lung cancer risks from occupational exposure to inhaled crystalline silica (i.e., quartz and cristobalite) [IARC 1997].

\subsubsection{Updated or New Studies Since the IARC Review}

Two studies discussed in this section have recently been updated: Checkoway et al. [1997, 1999] updated their previous mortality studies 


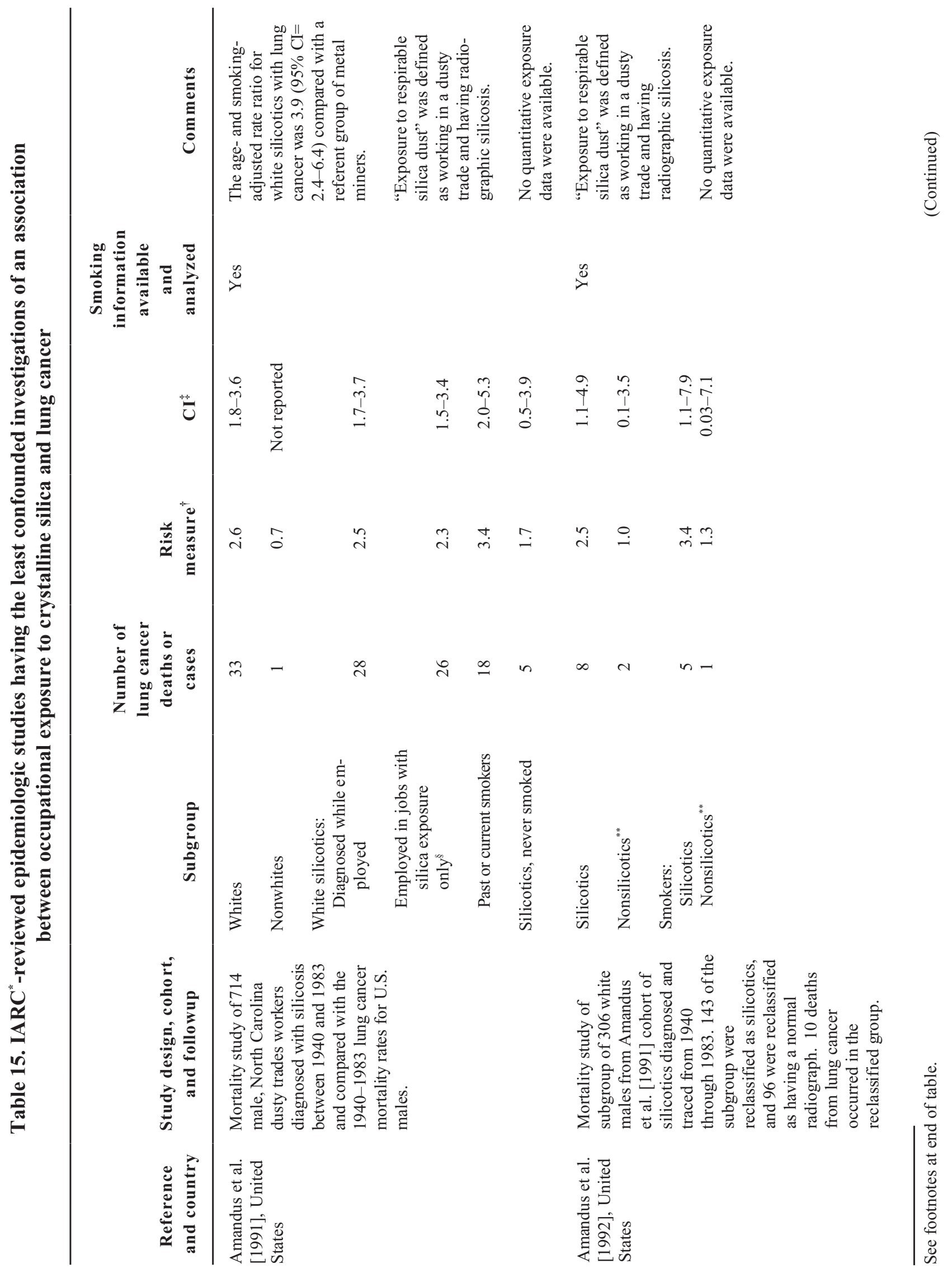




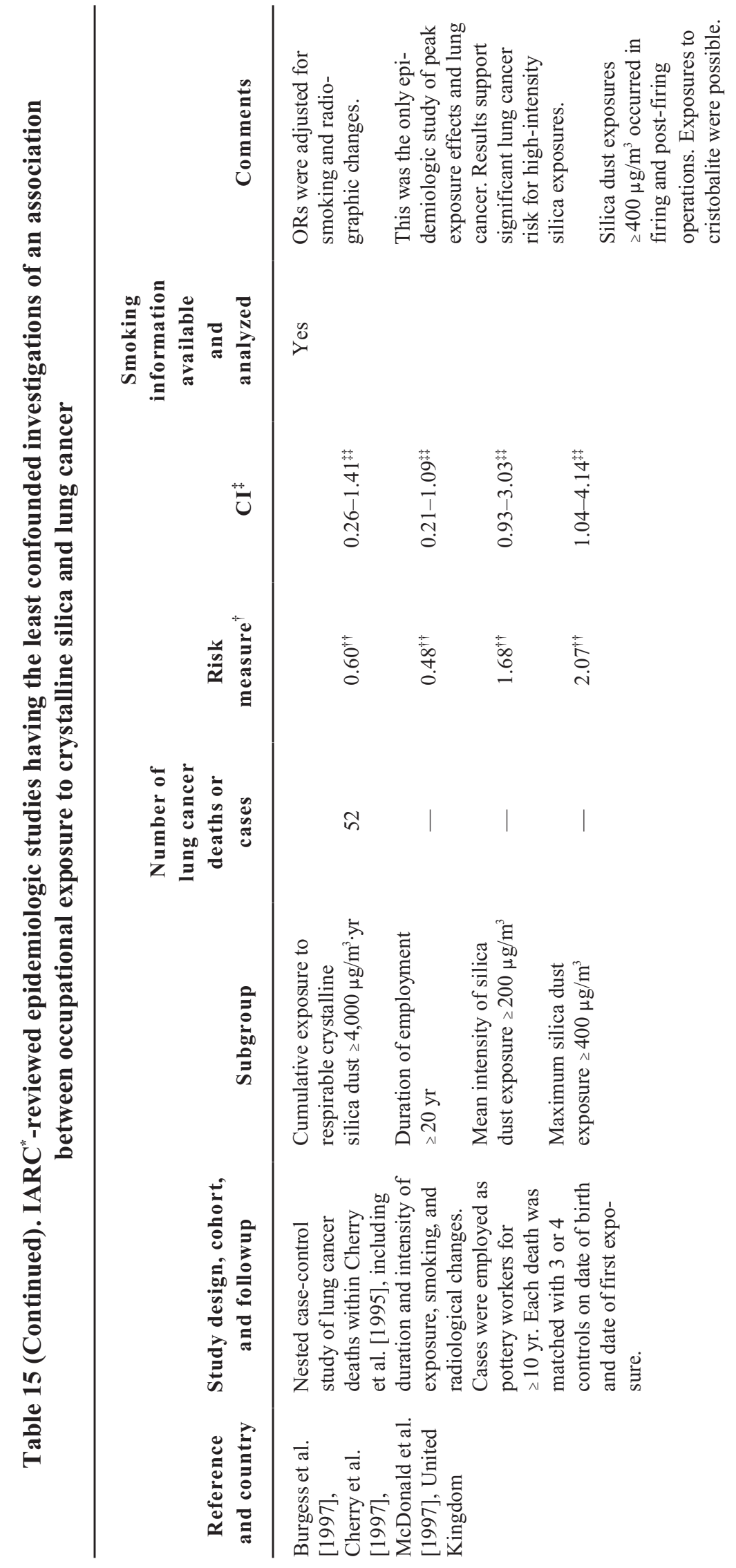




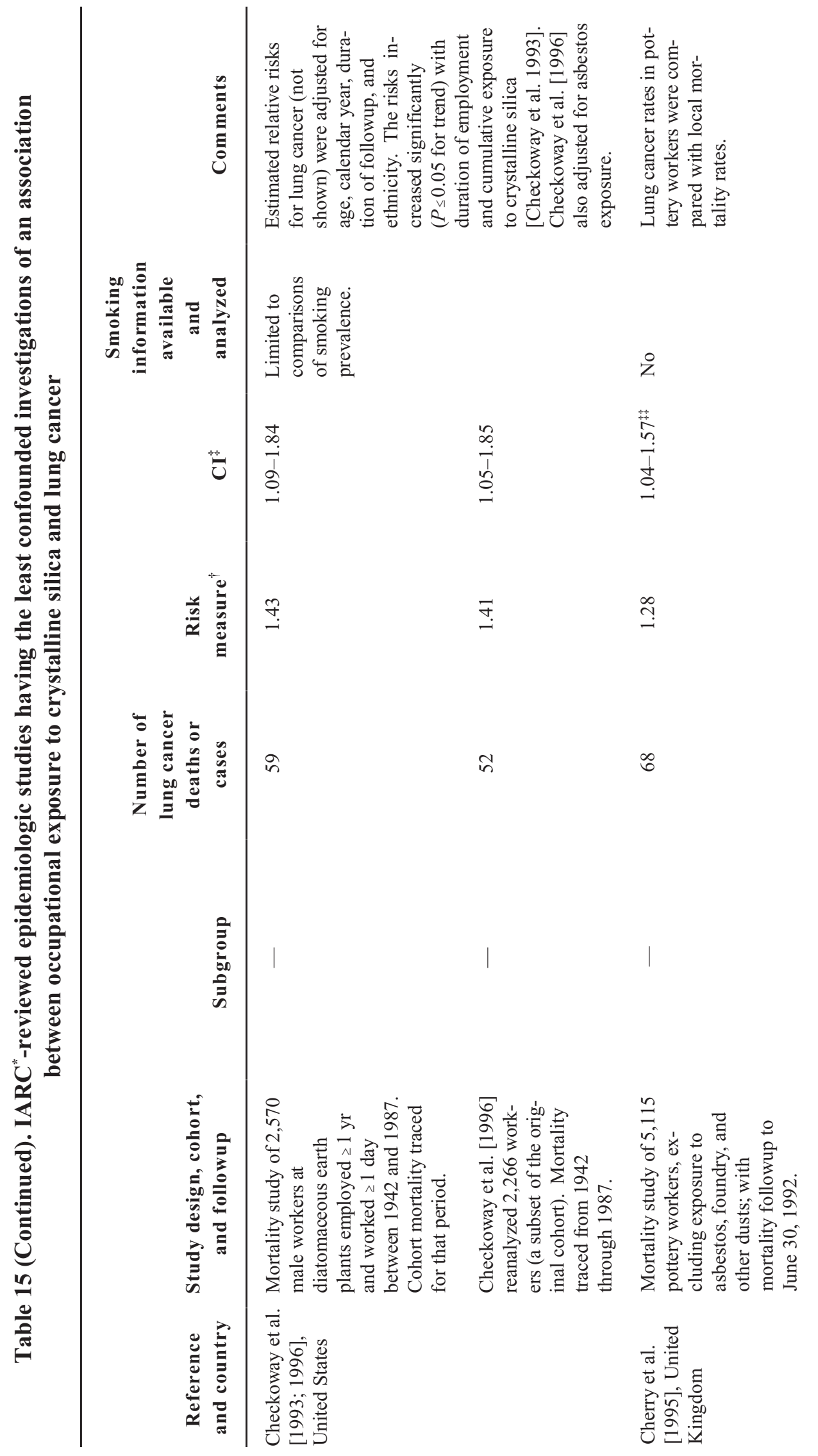




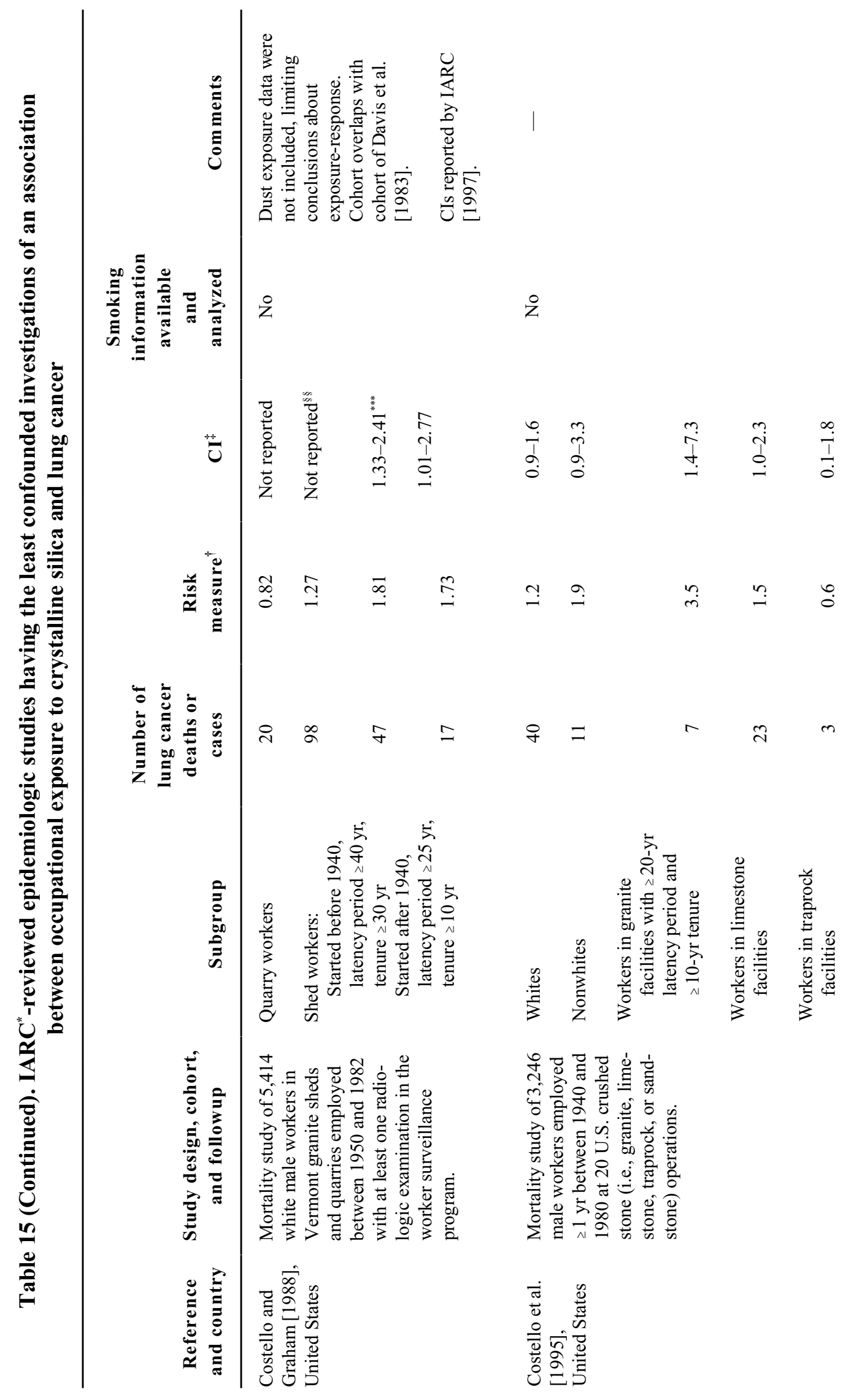




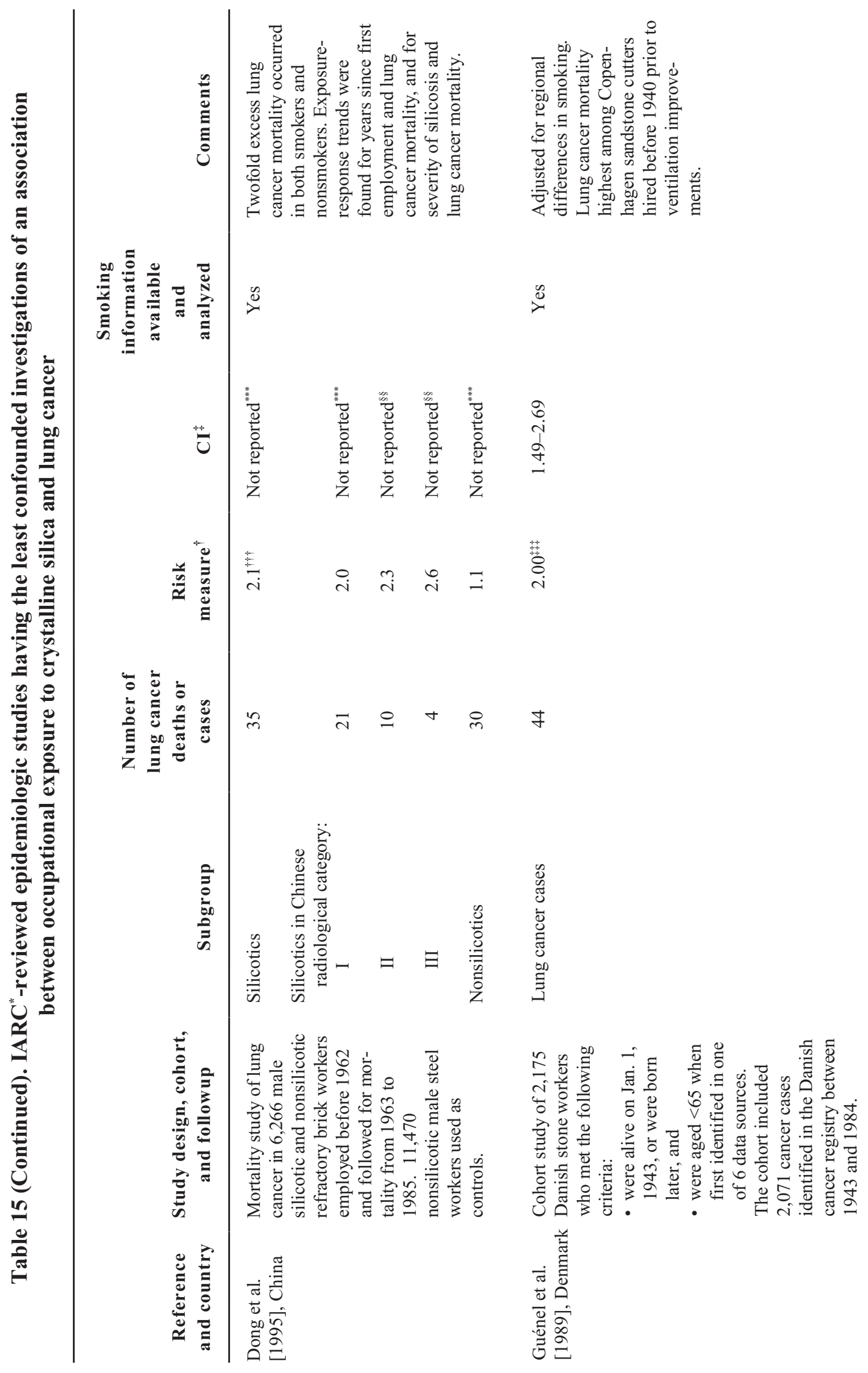




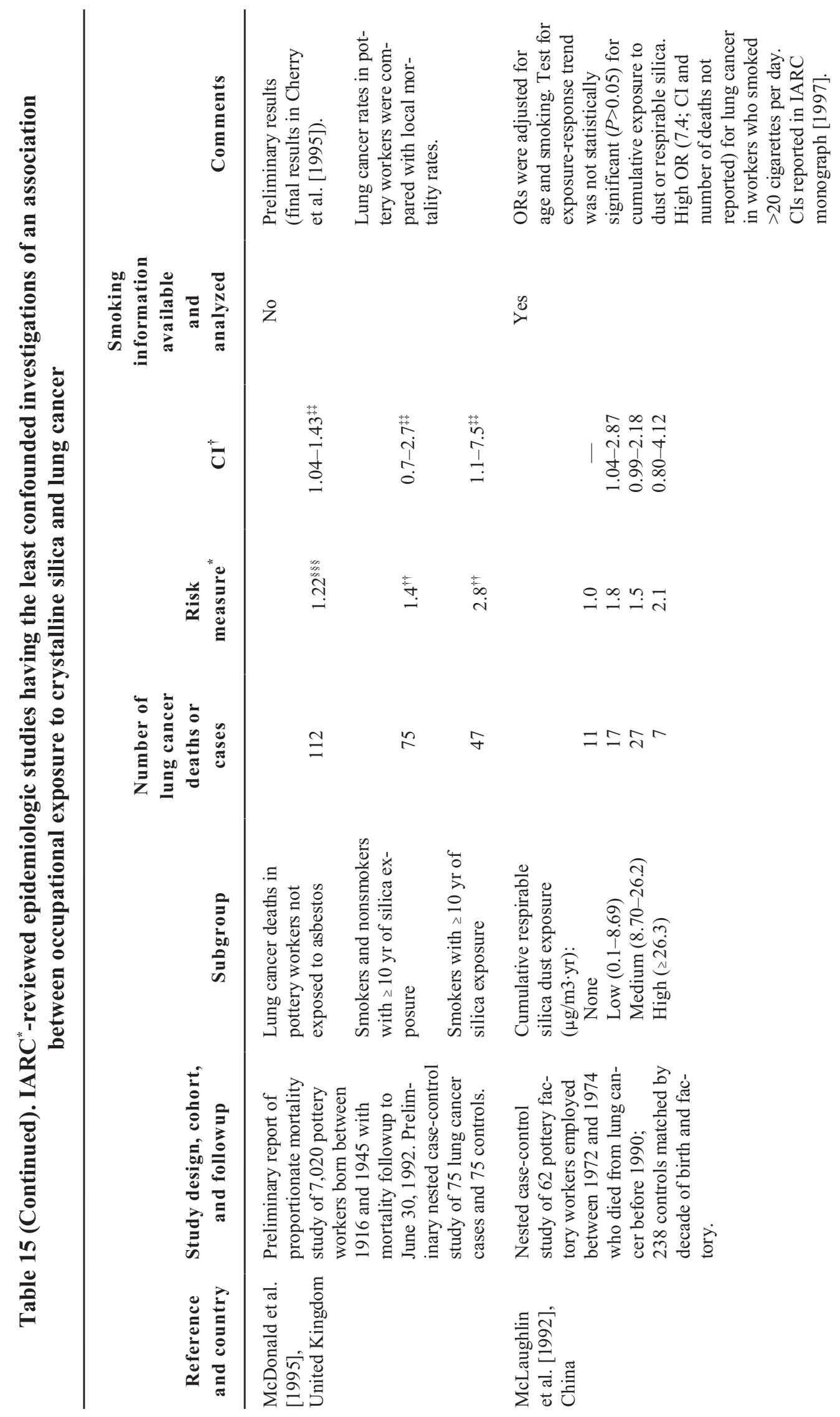




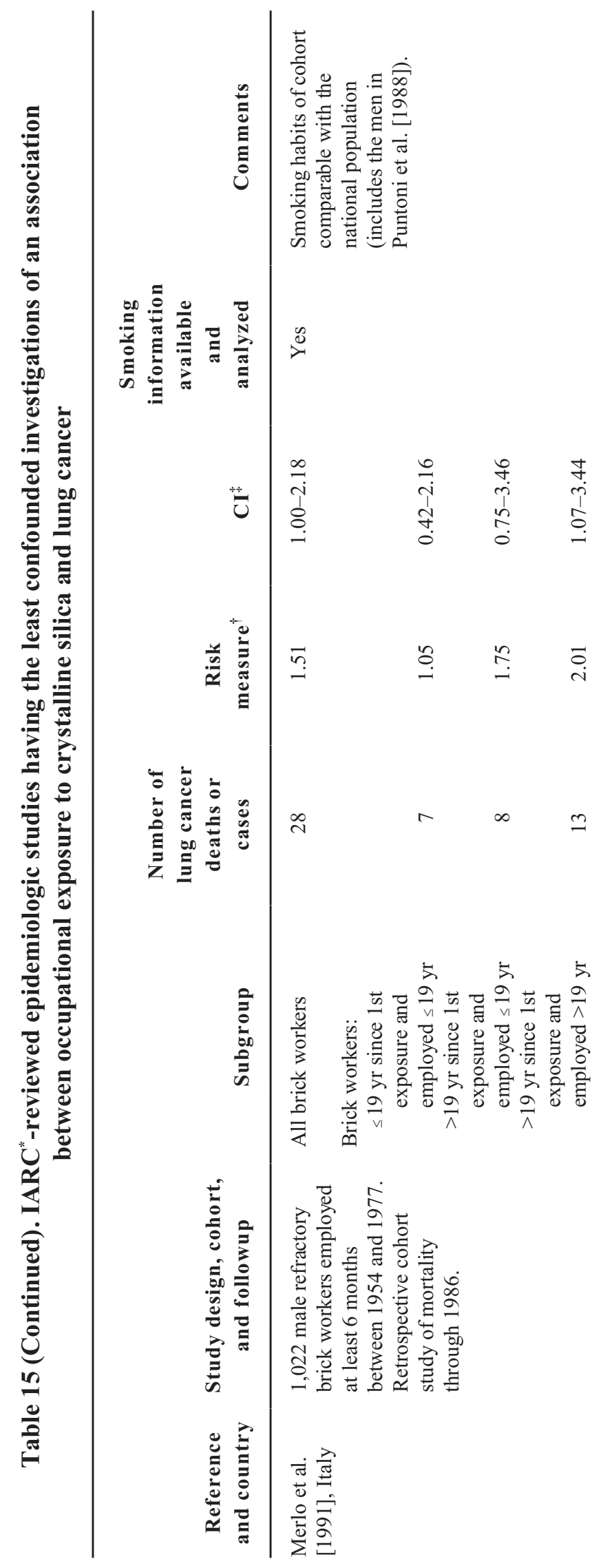




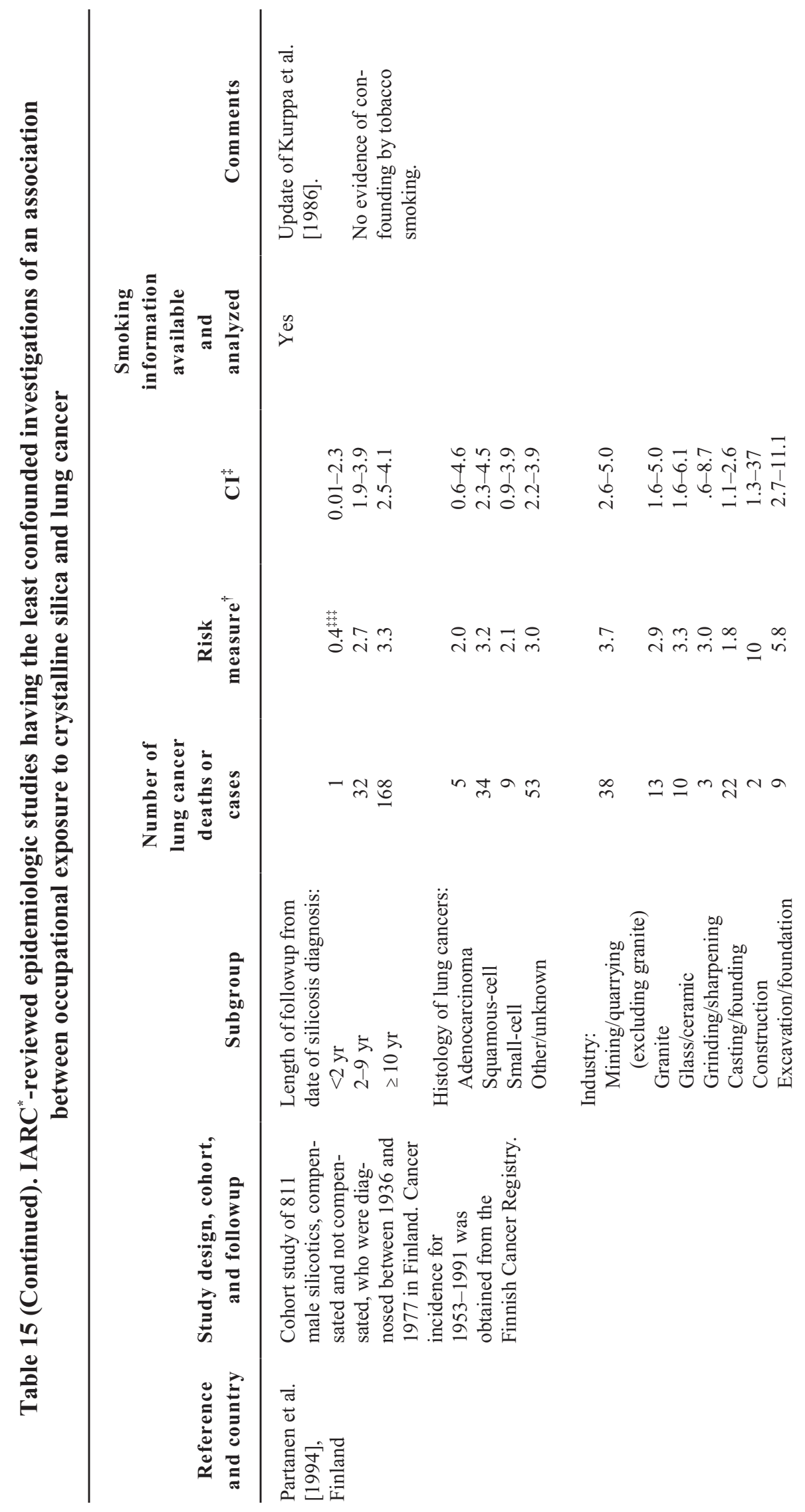




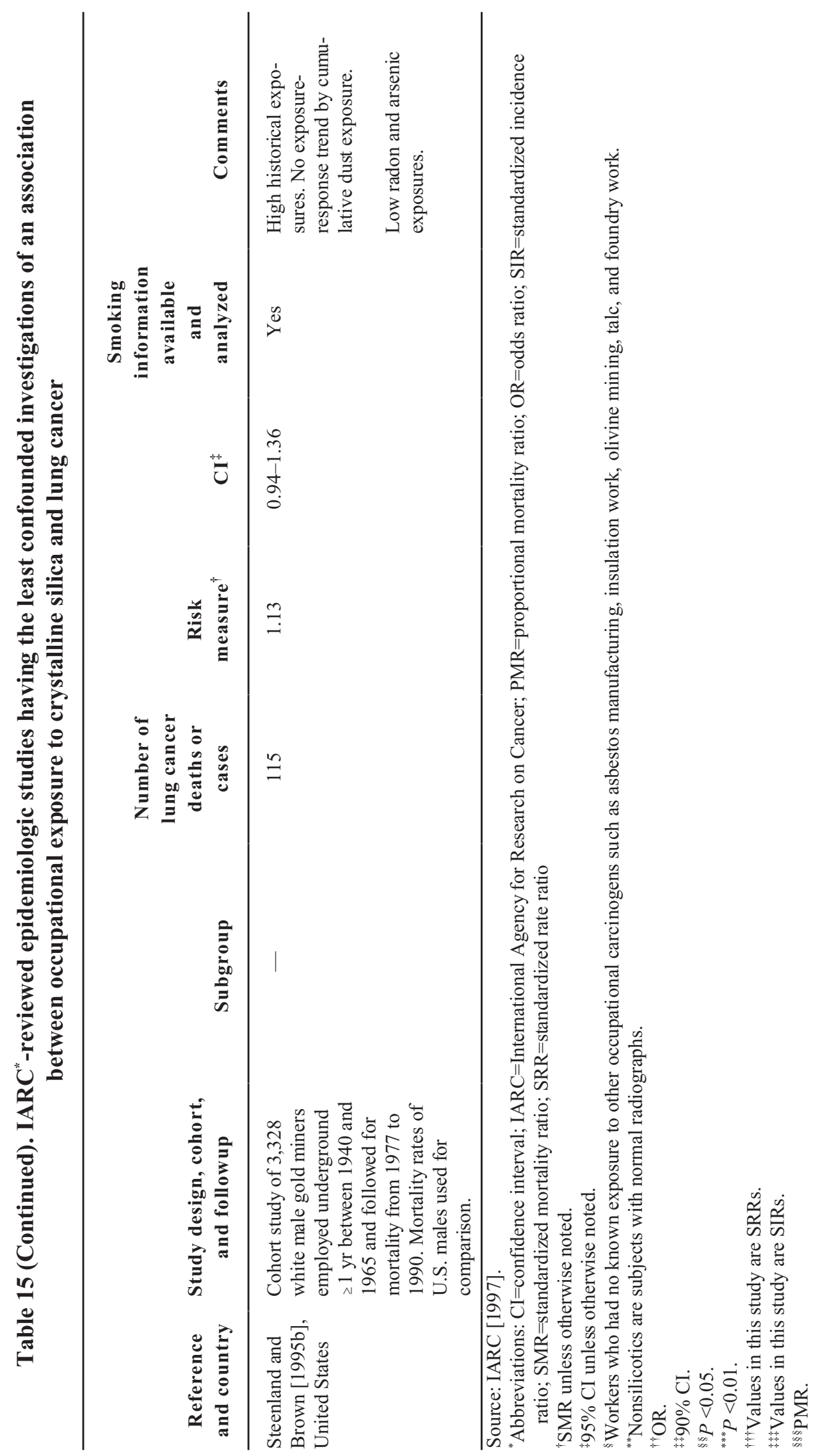

Respirable Crystalline Silica 
of diatomaceous earth workers [Checkoway et al. 1993, 1996] by including deaths after 1987 and through 1994, and by analyzing lung cancer risk among workers with radiographic silicosis. Lung cancer mortality risk was highest in the highest category of cumulative exposure to respirable crystalline silica (rate ratio with no exposure lag period $=2.11 ; 95 \%$ $\mathrm{CI}=1.07-4.1$; rate ratio for 15-year exposure lag period $=1.05 ; 95 \% \mathrm{CI}=0.99-1.11)$. The rate ratios were adjusted for the effects of age, calendar year, duration of followup, and ethnicity. Among workers with radiological silicosis (ILO category $\geq 1 / 0$ or large opacity; $n=81$ ), the lung cancer SMR was 1.57 (95\% CI= 0.43-4.03) [Checkoway et al. 1999]. For workers without silicosis (ILO category $<1 / 0$ ), the SMR was 1.19 (95\% CI=0.87-1.57). The SMRs were adjusted for age and calendar year and were based on the expected number of deaths for white U.S. males. For the nonsilicotic workers, a statistically significant, positive dose-response relationship $(P=0.02)$ was observed between SMRs for lung cancer and category of cumulative respirable silica exposure. The SMRs ranged from 1.05 in the lowest exposure category $\left(<0.5 \mathrm{mg} / \mathrm{m}^{3} \cdot\right.$ year, 13 deaths, $95 \% \mathrm{CI}=0.56-1.79)$ to 2.40 in the highest exposure category $\left(\geq 5.0 \mathrm{mg} / \mathrm{m}^{3} \cdot\right.$ year; 12 deaths, $95 \% \mathrm{CI}=1.24-4.20)$. For the 81 workers with radiographic silicosis, an SMR $>1.0$ was observed only in the highest exposure category (i.e., $\geq 5.0 \mathrm{mg} / \mathrm{m}^{3} \cdot$ year) (4 deaths observed; $\mathrm{SMR}=2.94 ; 95 \% \mathrm{CI}=0.80-7.53)$. These results suggest that silicosis may not be a necessary condition for silica-related lung cancer. However, radiographic surveillance of this cohort did not extend beyond the dates of employment termination, and autopsies were not routinely conducted [Checkoway et al. 1999].

Cherry et al. [1998] finalized the preliminary results of a nested case-control study of 52 lung cancer deaths in 5,115 pottery workers (see Burgess et al. [1997], Cherry et al. [1997], and McDonald et al. [1997] in Table 15). After adjustment for smoking and inclusion of a 20-, 10 -, or 0 -year lag period, mean respirable silica concentration (i.e., estimated daily 8-hr TWA airborne concentrations in $\left.\mu \mathrm{g} / \mathrm{m}^{3}\right)$ was associated with lung cancer $(P<0.008$ for each lag period):

$\begin{array}{lcc}\text { Lag } & \text { OR } & 95 \% C I \\ & & \\ 20 \mathrm{yr} & 1.60 & 1.11-2.31 \\ 10 \mathrm{yr} & 1.66 & 1.14-2.41 \\ 0 \mathrm{yr} & 1.67 & 1.13-2.47\end{array}$

However, exposure duration and cumulative silica dust exposure were not significantly associated with lung cancer mortality, regardless of lag time [Cherry et al. 1998]. The presence of small, parenchymal radiographic opacities (ILO category $\geq 1 / 0$ ) was not related to lung cancer mortality before adjustment for smoking $(P=0.78)$ or after adjustment for smoking and mean silica concentration $(P=0.68)$. The authors concluded "that crystalline silica may well be a human carcinogen" [Cherry et al. 1998].

Other studies published since the IARC review also investigated exposure-response associations for lung cancer and exposure to crystalline silica. Rafnsson and Gunnarsdóttir [1997] reported that the incidence of lung cancer cases among 1,346 diatomaceous earth workers in Iceland was not statistically significant for workers who had 9 years before start of followup and who were employed $\geq 5$ years (standardized incidence ratio [SIR] based on 3 cases observed $=2.70 ; 95 \% \mathrm{CI}=0.56-7.90)$ or employed $\leq 5$ years (SIR based on 2 cases observed $=1.19 ; 95 \% \mathrm{CI}=0.14-4.30)$.

de Klerk and Musk [1998] conducted a cohort study of 2,297 surface and underground gold miners in western Australia who participated in surveys of respiratory symptoms, smoking habits, and lung function in 1961, 1974, and 1975. Eighty-nine percent of the cohort was 
traced to the end of 1993 for trachea, bronchus, and lung cancer mortality and incidence of compensated silicosis (i.e., compensation awarded by the Pneumoconiosis Medical Board). A nested case-control analysis of the 138 lung cancer deaths found that lung cancer mortality was related to log total cumulative silica dust exposure after adjustment for smoking (cigarette, pipe, or cigar) and for the presence of bronchitis at survey (relative rate $=1.31 ; 95 \% \mathrm{CI}=1.01-1.70)$. However, the effect of cumulative silica dust exposure on lung cancer mortality was not significant after adjustment for smoking, bronchitis, and compensation for silicosis (relative rate $=1.20$; $95 \% \mathrm{CI}=0.92-1.56)$. Other silica exposure variables (i.e., duration of underground or surface employment and intensity of underground or surface exposure) were not significantly related to lung cancer mortality $(P>0.15)$ after adjustment for smoking and bronchitis. Cigarette smoking (relative rate $=32.5$; 95\% CI $=4.4-241.2$ for $\geq 25$ cigarettes smoked per day), incidence of a compensation award for silicosis after lung cancer diagnosis (relative rate $=1.59 ; 95 \% \mathrm{CI}=1.10-2.28)$, and presence of bronchitis at survey (relative rate $=1.60$; 95\% CI $=1.09-2.33$ ) were significantly related to lung cancer mortality [de Klerk and Musk 1998]. The results of this study do not support a relationship between lung cancer and silica exposure in the absence of silicosis (i.e., a compensation award for silicosis after lung cancer diagnosis). However, controlling for silicosis compensation and bronchitis may have masked a silica effect because both are markers of silica exposure.

Hnizdo et al. [1997] conducted a nested case-control study of lung cancer deaths in a cohort of 2,260 white South African underground gold miners. (A lung cancer mortality cohort study had been conducted earlier [Hnizdo and Sluis-Cremer 1991]). The mineral content of the rock in the gold mines was mostly quartz $(70 \%-90 \%)$, silicates $(10 \%-30 \%)$, pyrite $(1 \%-4 \%)$, and heavy minerals with grains of gold and uranium-bearing minerals (2\%-4\%). Seventy-eight miners who died from lung cancer (69 of the 78 had a necropsy) during 1970-1986 were matched by year of birth with 386 control subjects from the same cohort [Hnizdo et al. 1997]. Conditional logistic regression models were used to analyze the relationship of lung cancer mortality with cigarette smoking (pack-years), cumulative "dust" exposure $\left(\mathrm{mg} / \mathrm{m}^{3} \cdot\right.$ year$)$, years of underground mining, incidence of radiographic silicosis (ILO category $\geq 1 / 1$ diagnosed up to 3 years before death of a matched case), and uranium production or uranium grade of the ore in the gold mine. Radon progeny measurements in the gold mines were not available.

Lung cancer mortality was associated with cigarette smoking, cumulative dust exposure (lag time was 20 years from death), duration of underground mining (lag time was 20 years from death), and silicosis. The best-fitting model predicted relative risks of $2.45(95 \% \mathrm{CI}=$ 1.2-5.2) for silicosis and the following relative risks for various pack-years of smoking:

$\begin{array}{ccc}\text { Pack-years } & 95 \% \text { CI } & \text { Relative risk } \\ <6.5 & - & 1 \\ 6.5-20 & 0.7-16.8 & 3.5 \\ 21-30 & 1.3-25.8 & 5.7 \\ >30 & 3.1-56.2 & 13.2\end{array}$

The authors stated that variables representing uranium mining were not significantly related to lung cancer mortality (modeling results for these variables were not presented) [Hnizdo et al. 1997]. The authors proposed three explanations for their results:

- Miners with high dust exposure who develop silicosis have increased lung cancer risk. 
- High silica dust exposure concentrations are important in the pathogenesis of lung cancer, and silicosis is coincidental.

- High silica dust exposure concentrations are a surrogate measure of exposure to radon progeny [Hnizdo et al. 1997].

\subsubsection{Lung Cancer Meta-Analyses}

Meta-analysis and other systematic literature review methods are useful tools for summarizing exposure risk estimates from a large amount of information [Mulrow 1994]. Metaanalyses or summary reviews of epidemiologic studies of silicotics with lung cancer have been conducted by investigators in the United States [Steenland and Stayner 1997; Smith et al. 1995] and Japan [Tsuda et al. 1997]. IARC is performing a pooled analysis of epidemiologic data from several cohorts to investigate lung cancer risks in nonsilicotic workers.

Steenland and Stayner [1997] and IARC [1997] found that the majority of studies of silicotics reported statistically significant excess lung cancer risks across different countries, industries, and time periods while controlling for the effects of cigarette smoking [Steenland and Stayner 1997; IARC 1997]. Exposure-response gradients were also observed. The summary relative risk was 2.3 (95\% CI $=2.2-2.6)$ for 19 cohort and casecontrol studies of silicotics - excluding studies of miners and foundry workers because of potential exposure to other carcinogens, and omitting autopsy studies and proportionate mortality studies because of possible selection biases [Steenland and Stayner 1997]. Fifteen of the 19 studies directly or indirectly controlled for the effects of smoking. The summary relative risk of 16 cohort ${ }^{*}$ and case-control studies

${ }^{*}$ Cohort size ranged from 969 to 6,266 workers. of silica-exposed workers was $1.3(95 \% \mathrm{CI}=$ 1.2-1.4) — a moderate and statistically significant relative risk estimate [Steenland and Stayner 1997]. Eight of the 16 studies controlled for the effects of smoking, either directly or indirectly.

Another meta-analysis of 23 lung cancer studies of silicotics (including 14 of the studies analyzed by Steenland and Stayner [1997]) reported a pooled risk estimate of $2.2(95 \% \mathrm{CI}=$ 2.1-2.4) [Smith et al. 1995]. The statistically significant pooled risk estimates from both meta-analyses strongly support an association between silicosis and lung cancer. The increased risk of lung cancer for silicotics is also supported by the following [IARC 1997]:

1. The magnitude of the risk estimates (i.e., most studies reported risks greater than 2.0 for silicotics after adjusting for the effects of cigarette smoking - compared with exposed nonsilicotics or the general population)

2. The observation of exposure-response gradients with various indicators of exposure

3. Consistent findings of excess risk in different countries, industries, and time periods

4. Two studies that provided reasonable evidence for an unconfounded association (i.e., Amandus et al. [1991, 1992, 1995] and Partanen et al. [1994], an update of Kurppa et al. [1986])

Tsuda et al. [1997] conducted a lung cancer meta-analysis of pneumoconiosis or silicosis studies (excluding asbestosis). Lung cancer risk estimates were pooled from 32 mortality studies published from 1980 to 1994 . The estimated rate ratios were similar to those reported by Steenland and Stayner [1997] and Smith et al. [1995]: 


\begin{tabular}{|c|c|c|}
\hline & Rate ratio & $95 \% C I$ \\
\hline All studies $\left(32^{\dagger}\right)$. . & 2.74 & $2.60-2.90$ \\
\hline $\begin{array}{l}\text { Cohort studies only } \\
\text { (25 of } 32) \ldots\end{array}$ & 2.77 & $2.61-2.94$ \\
\hline $\begin{array}{c}\text { Case-control studies } \\
(5 \text { of } 32) \ldots \ldots\end{array}$ & 2.84 & $2.25-3.59$ \\
\hline
\end{tabular}

\subsubsection{Other Cancers}

Mortality studies of workers have reported statistically significant excesses of deaths from stomach or gastric cancer in iron ore miners [St. Clair Renard 1984; Lawler et al. 1985; Mur et al. 1987], Canadian gold miners [Muller et al. 1983; Shannon et al. 1987; Miller et al. 1987; Kusiak et al. 1993b], lead and zinc miners [Belli et al. 1989], brick production workers [Katsnelson and Mokronosova 1979], foundry and other metal workers [Neuberger and Kundi 1990], jewelry workers [Hayes et al. 1993; Dubrow and Gute 1987; Sparks and Wegman 1980], farmers (reviewed by Blair and Zahm [1991]), and farm workers [Stubbs et al. 1984] (reviewed by Zahm and Blair [1993]). A recent case-control study of 250 male hospital patients in Canada found a statistically significant excess of pathologically confirmed stomach cancer among the 25 patients who reported a history of "substantial" occupational exposure to crystalline silica compared with 2,822 controls $(\mathrm{OR}=1.7 ; 95 \%$ $\mathrm{CI}=1.1-2.7$ after adjusting for the effects of age, birthplace, education, and cigarette smoking) [Parent et al. 1998]. However, in a review of epidemiologic studies of gastric cancer and dusty occupations, Cocco et al. [1996] noted that because most studies did not adjust for the effects of confounding factors or assess a dose-response relationship, evidence was insufficient to conclude that silica is a gastric carcinogen.

\footnotetext{
${ }^{\dagger}$ Two of the studies are proportionate mortality studies for which rate ratios were not reported.
}

For workers who may have been exposed to crystalline silica, there have been infrequent reports of statistically significant excesses of deaths or cases of other cancers such as nasopharyngeal or pharyngeal cancer [Chen et al. 1992; Carta et al. 1991], salivary gland cancer [Zheng et al. 1996], liver cancer [Chen et al. 1992; Hua et al. 1992], bone cancer [Forastiere et al. 1989; Steenland and Beaumont 1986], pancreatic cancer [Kauppinen et al. 1995], skin cancer [Partanen et al. 1994; Rafnsson and Gunnarsdóttir 1997], esophageal cancer [Pan et al. 1999; Xu et al. 1996; Belli et al. 1989], cancers of the digestive system [Decoufle and Wood 1979], intestinal or peritoneal cancer [Amandus et al. 1991; Goldsmith et al. 1995; Costello et al. 1995], lymphopoietic or hematopoietic cancers [Redmond et al. 1981; Silverstein et al. 1986; Steenland and Brown 1995b], brain cancer [Rafnsson and Gunnarsdóttir 1997], and bladder cancer [Bravo et al. 1987]. Again, an association has not been established between these cancers and exposure to crystalline silica.

\subsection{Other Nonmalignant Respiratory Diseases and Related Conditions}

\subsubsection{COPD}

\subsubsection{Definition}

COPD describes chronic airflow limitation that is usually irreversible [ATS 1987; Becklake 1992; Snider 1989]. COPD includes four interrelated disease processes: chronic bronchitis, emphysema, asthma [Barnhart 1994; Snider 1989], and peripheral airways disease [ATS 1987]. Cigarette smoking is a major cause of COPD, but community air pollution and occupational exposure to dust, particularly among smokers, also contribute to COPD [Becklake 1992]. 


\subsubsection{Epidemiologic Studies}

Although thousands of studies have been published about occupational exposure to nonorganic dusts and COPD, only 13 studies of 4 cohorts of silica-exposed workers met rigorous methodologic criteria for a review conducted by Oxman et al. [1993]. Three of the cohorts were coal miners and one was South African gold miners. According to Oxman et al. [1993], the studies provided evidence that exposure to gold mine dust is an important cause of COPD, particularly in smokers, and that the risk of COPD appeared to be greater for gold miners than for coal miners.

\subsubsection{Asthma}

Crystalline silica has not been identified as an occupational asthma-inducing agent [Chan-Yeung 1994], and no published epidemiologic studies have specifically investigated whether asthma is related to crystalline silica dust exposure.

\subsubsection{Chronic Bronchitis}

\subsubsection{Definition}

Chronic bronchitis is clinically defined as the occurrence of chronic or recurrent bronchial hypersecretion (i.e., a productive cough) on most days of the week for at least 3 months of 2 sequential years [ATS 1987, 1995; Barnhart 1994]. The excess mucus secretion should not be related to a disease such as TB [ATS 1987, 1995]. Chronic bronchitis has been associated with both airflow obstruction and abnormalities in gas exchange [Barnhart 1994]. Although the terms "industrial bronchitis" and "occupational bronchitis" traditionally refer to chronic bronchitis that is associated with occupational exposure, bronchitic symptoms may also occur after occupational exposures that are acute or that last less than 2 years. An association between reduced ventilatory function and bronchitic symptoms has been reported in studies of workers exposed to coal dust, asbestos, or dust that contained crystalline silica [Barnhart 1994]. However, cigarette smoking is also associated with chronic bronchitis and must be considered when investigating the relationship between occupational exposures and bronchitic symptoms [Barnhart 1994; ATS 1997].

\subsubsection{Epidemiologic Studies}

Statistically significant $(P<0.05)$ relationships independent of smoking were found between exposure to gold mine dust and chronic bronchitis or chronic sputum production in cross-sectional studies of gold miners in South Africa [Wiles and Faure 1977; Cowie and Mabena 1991] and Australia [Holman et al. 1987]. However, no statistically significant relationships independent of smoking were found between exposure and chronic bronchitis or bronchitic symptoms in crosssectional studies of molybdenum miners [Kreiss et al. 1989b], uranium miners [Samet et al. 1984], taconite miners [Clark et al. 1980], Indian agate grinders and chippers [Rastogi et al. 1991], and a populationbased study of South African gold miners [Sluis-Cremer et al. 1967] (Table 16).

Wiles and Hnizdo [1991] studied the relationship between mortality, airflow obstruction, and mucus hypersecretion in 2,065 South African gold miners. They found that after standardization for airways obstruction, mucus hypersecretion was not related to mortality from COPD (54 deaths). However, mucus hypersecretion remained significantly related to mortality from ischemic heart disease and all causes of death, even after adjustment for years of cigarette smoking and particle-years of exposure to gold mine dust [Wiles and Hnizdo 1991].

\footnotetext{
Cumulative exposure, duration of exposure, or intensity of exposure.
} 


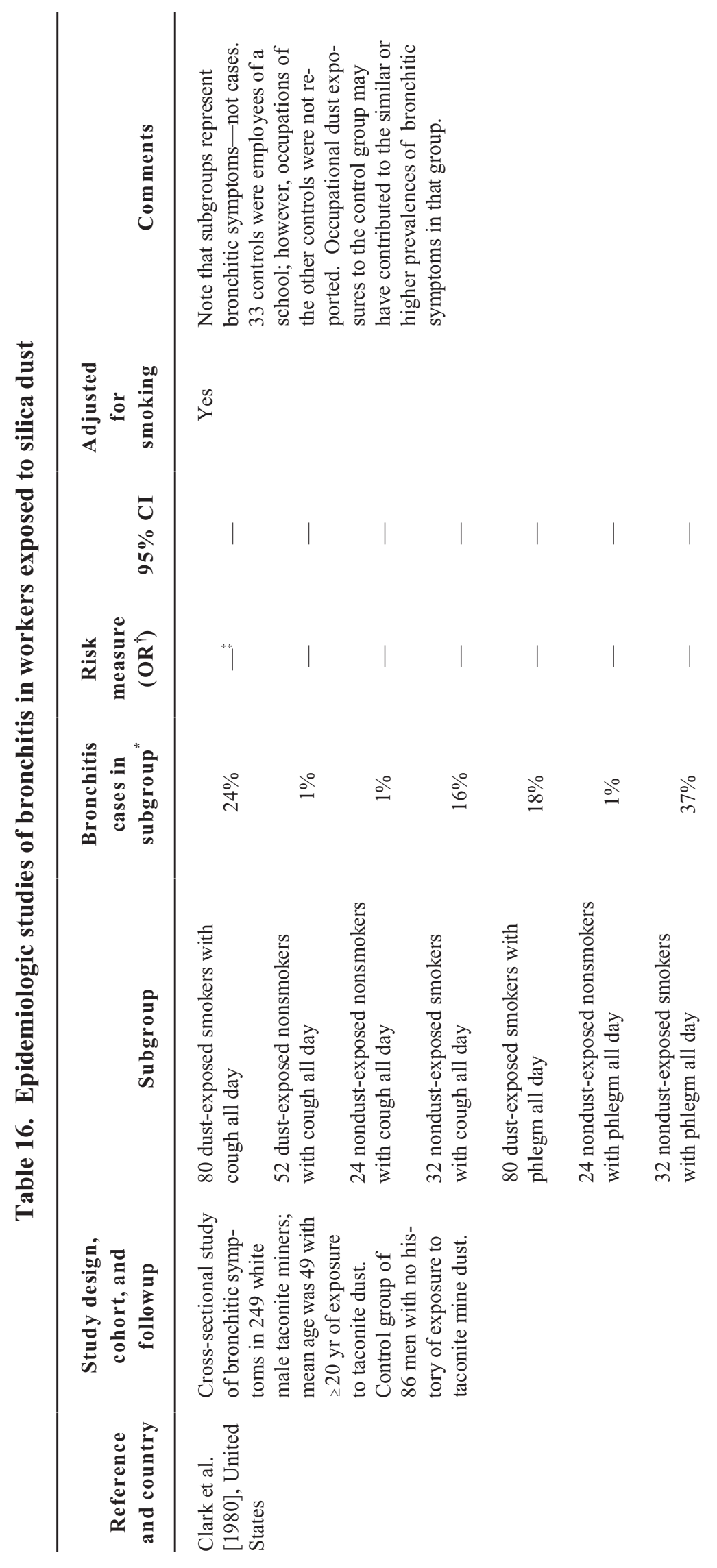




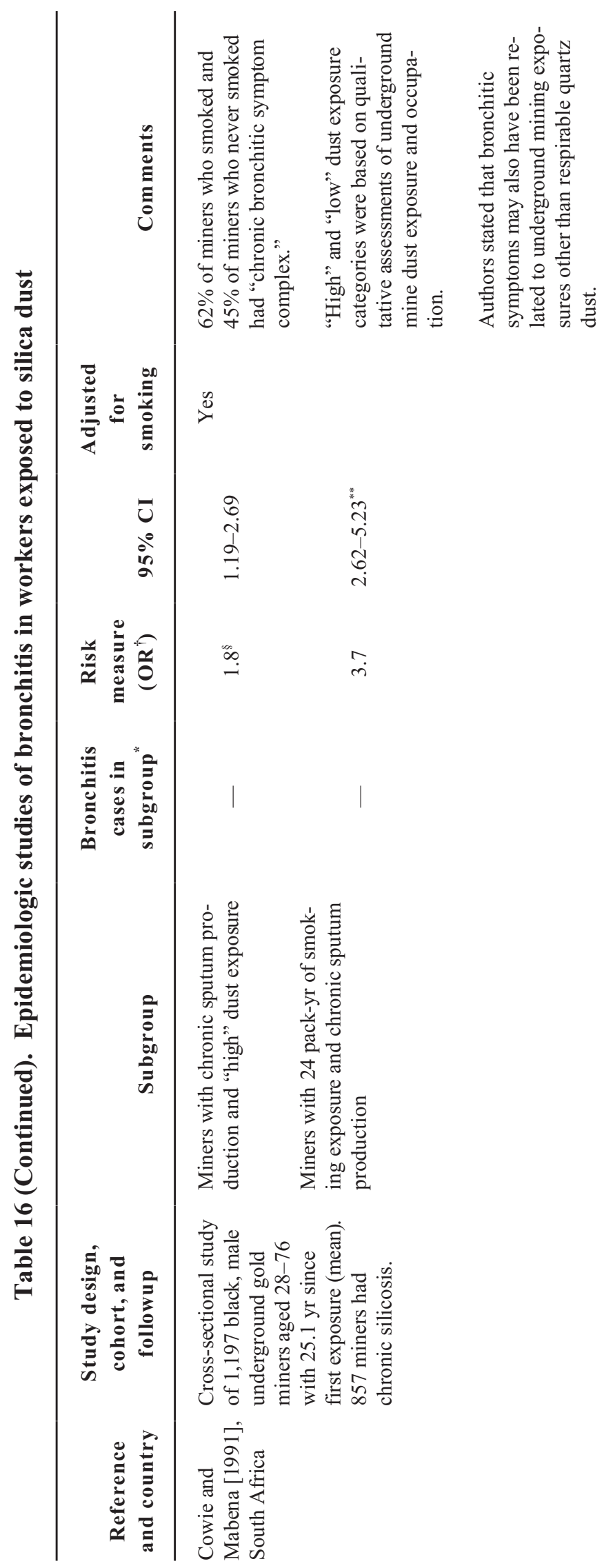




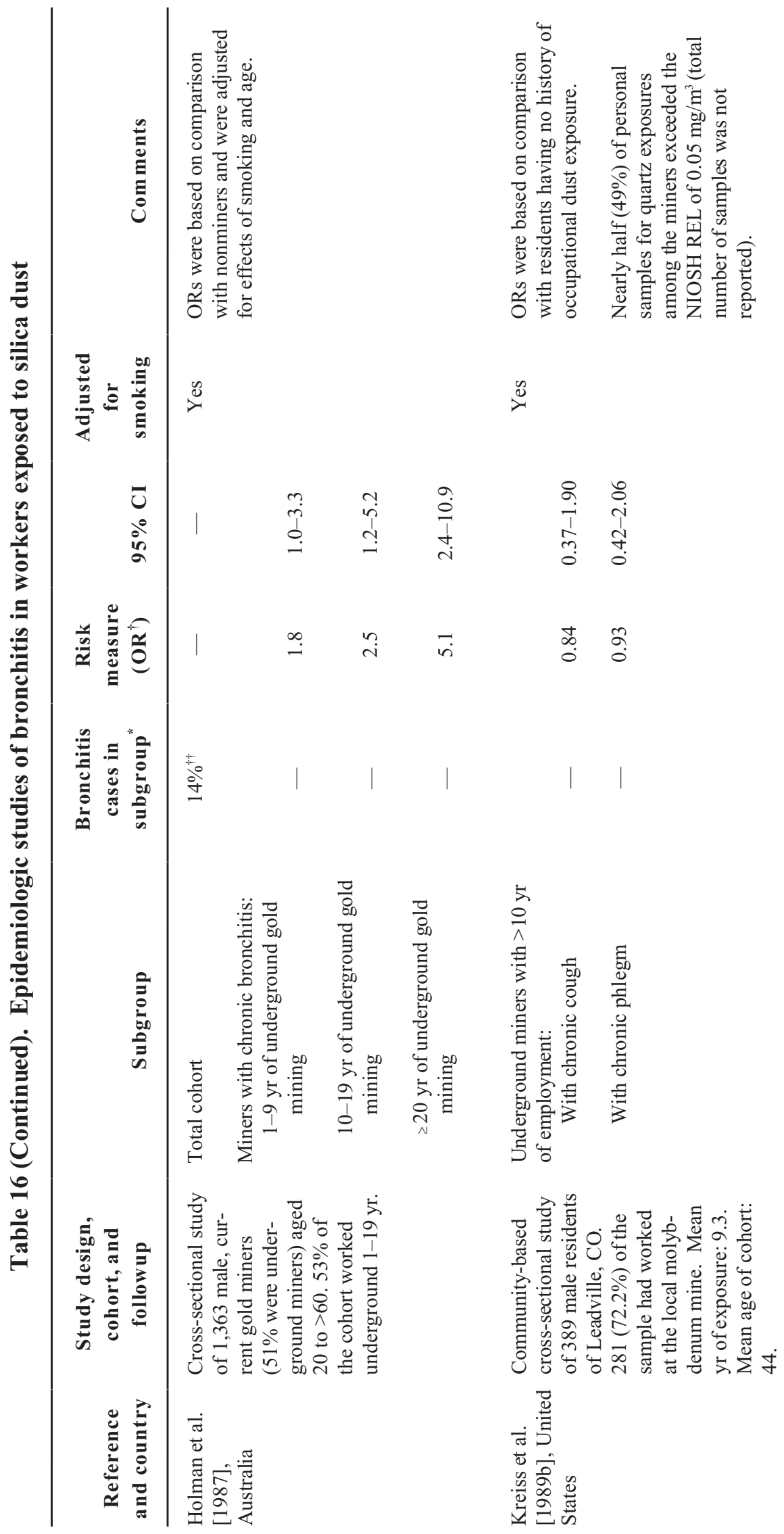




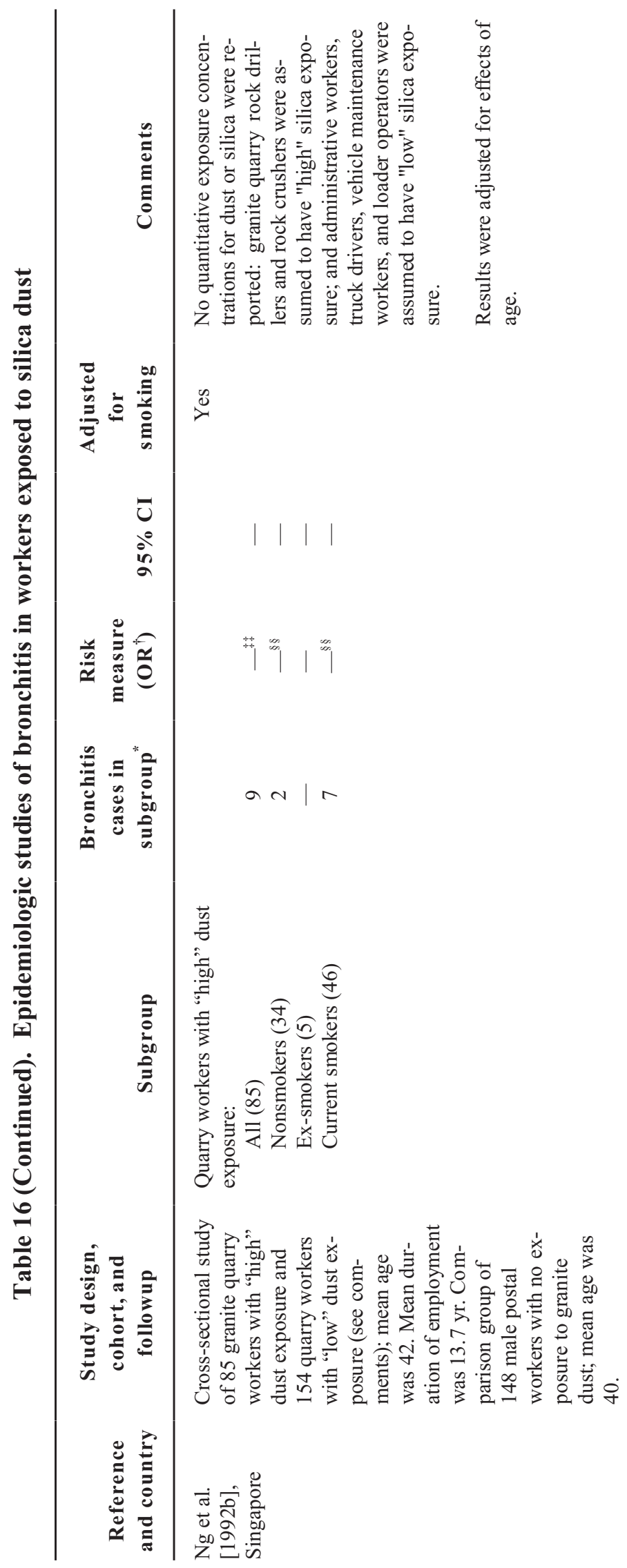




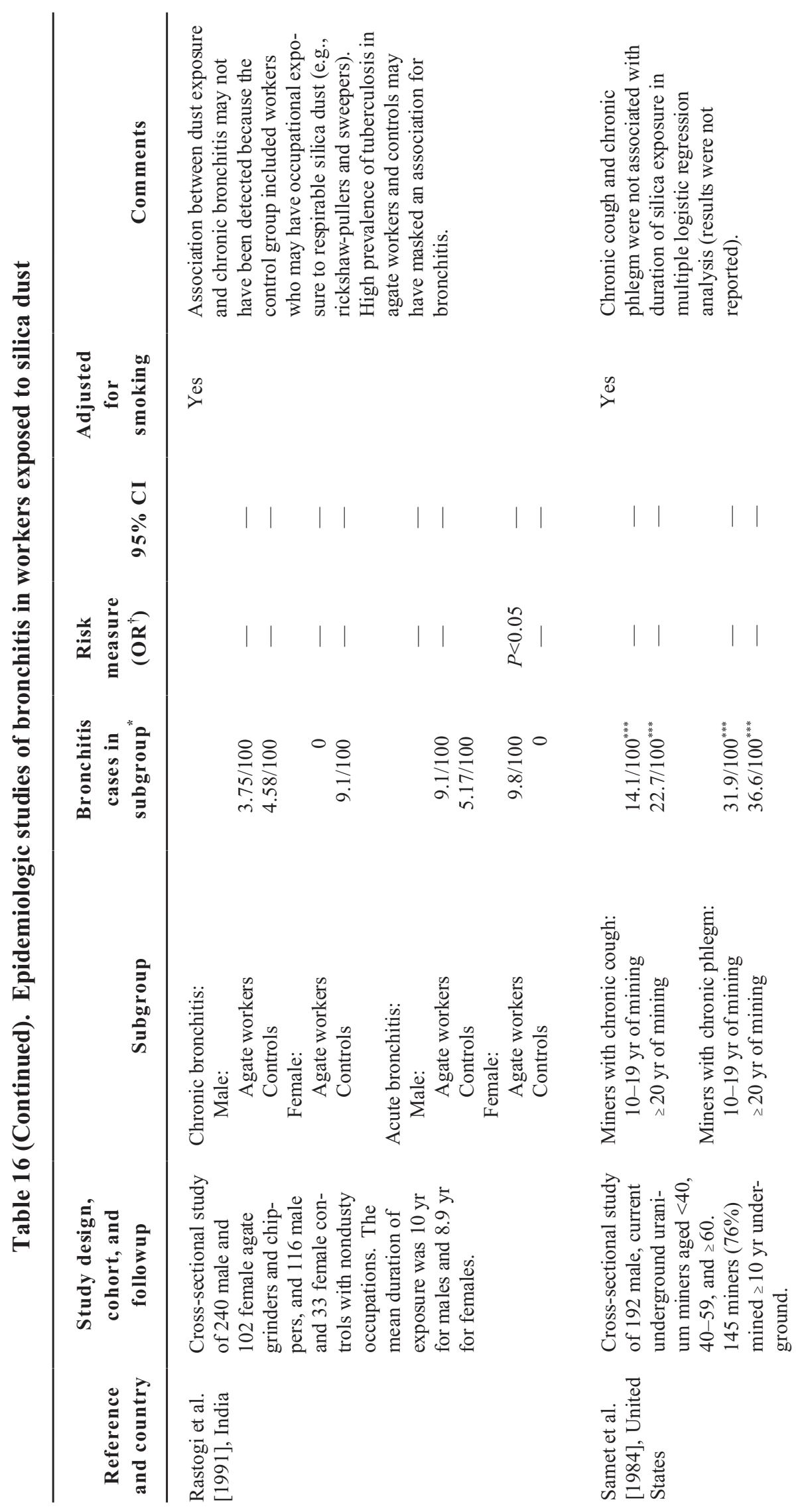

氖 


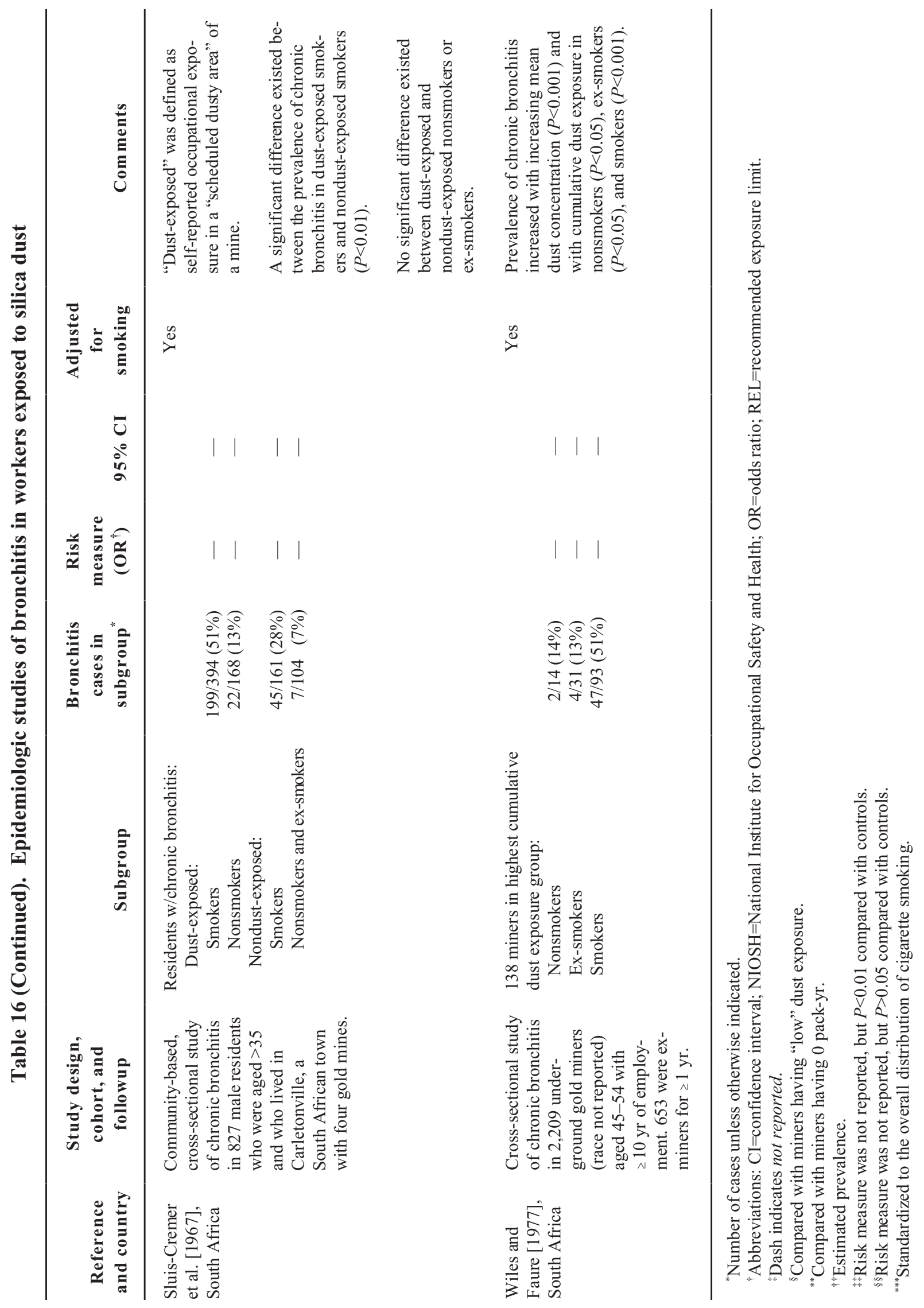


A mortality study of workers in "dusty trades" reported a statistically significant number of deaths from bronchitis when compared with mortality rates for other white males in the United States $(P<0.05 ; 6$ deaths observed; 0.8 deaths expected) [Amandus et al. 1991].

The discrepancies among the cross-sectional studies of bronchitis in quartz-exposed populations may be attributable to the presence or absence of concurrent exposures among the cohorts that have been studied [Kreiss et al. 1989b]. Particle size is another factor that may have affected the results. The dust in one work environment may have had a higher proportion of particles that were not of respirable size ${ }^{\S}$ compared with dust in another work environment. Larger-sized dust particles may be responsible for large-airways diseases such as chronic bronchitis, whereas respirable dust particles are responsible for lung parenchymal diseases such as silicosis [Morgan 1978]. In addition to physical size, the shape and density of inorganic dust particles also influence where they are deposited in the airways and whether they can be cleared from the airways [Becklake 1985].

\subsubsection{Abnormalities in Pulmonary Function Tests}

\subsubsection{Definition}

Pulmonary function tests measure lung volumes (e.g., vital capacity [VC]), air flow (e.g., expiratory volume in 1 second $\left[\mathrm{FEV}_{1}\right]$ ), blood gas exchange, and other aspects of lung function [Rosenstock 1994]. Spirometric pulmonary function tests routinely performed are forced vital capacity (FVC), $\mathrm{FEV}_{1}$, and $\mathrm{VC}$ [Parkes 1982]. Lung function tests alone cannot diagnose any particular disease [Parkes 1982]; however, they are an important part of

\footnotetext{
${ }^{\S}$ Respirable particles have aerodynamic diameters less than approximately $10 \mu \mathrm{m}$.
}

the clinical evaluation of workers with occupational lung diseases. Nonoccupational factors (e.g., the subject's age, height, racial group, and smoking habit) as well as the quality and interpretation of the spirometric testing can influence pulmonary function test results [Parkes 1982; Rosenstock 1994; Crapo 1994]. In general, an $\mathrm{FEV}_{1}$ loss of about 20 to $30 \mathrm{ml} /$ year in nonsmokers or $>60 \mathrm{ml} /$ year in smokers [Crapo 1994] may suggest a decline greater than expected. Wagner [1994] suggests further clinical evaluation of workers with a $15 \%$ decrease from the baseline percentage of predicted value for $\mathrm{FEV}_{1}$ or $\mathrm{FVC}$ (e.g., from $105 \%$ to $90 \%$ of the predicted $\mathrm{FEV}_{1}$ ).

Loss of $\mathrm{FEV}_{1}$ has been associated with an increased risk of death from various diseases, including COPD [Crapo 1994; Tockman and Comstock 1989; Anthonisen et al. 1986; Foxman et al. 1986]. Although pulmonary function tests can define and measure respiratory impairment, they are not a diagnostic tool for silicosis or a measure of silica exposure [Wagner 1997], because no single pattern of pulmonary function abnormality is associated with silica exposure or silicosis [Wagner 1997; Weill et al. 1994; ATS 1997].

\subsubsection{Epidemiologic Studies- Quantitative Estimates of Dust-Related Loss of Lung Function}

Most epidemiologic studies of pulmonary function and occupational exposure to respirable crystalline silica are cross-sectional studies that do not provide quantitative modeling of cumulative dust exposure. They report occupationally related annual declines in ventilatory function in workers with and without silicosis (i.e., gold and other hard-rock miners, iron ore miners, coal miners, talc miners, slate workers, and kaolin workers). Details of these studies are reported elsewhere [ATS 1997; Becklake 
1985, 1992; Eisen et al. 1995; NIOSH 1995a; EPA 1996; Graham et al. 1994].

Thirteen studies with quantitative dust exposure data for four silica-exposed cohorts found statistically significant associations between loss of lung function (i.e., $\mathrm{FEV}_{1}, \mathrm{FVC}$ ) and cumulative respirable dust exposure in coal miners and South African gold miners [Oxman et al. 1993]. The study of gold miners [Hnizdo 1992] estimated that a 50-year-old, white South African gold miner (nonsmoker) who was exposed to gold mine dust (containing $0.09 \mathrm{mg} / \mathrm{m}^{3}$ of crystalline silica) at an average respirable concentration of $0.3 \mathrm{mg} / \mathrm{m}^{3}$ for 24 years would lose $236 \mathrm{ml}$ of $\mathrm{FEV}_{1}(95 \% \mathrm{CI}=$ 134-337). This loss is equivalent to about half of the estimated loss of $\mathrm{FEV}_{1}$ in a typical U. S. male (nonminer) who smoked one pack of cigarettes per day for 30 years (i.e., $552 \mathrm{ml}$ [95\% CI=461-644]) [Dockery et al. 1988; Hnizdo 1992]. The combined effects of respirable dust exposure and smoking on the loss of $\mathrm{FEV}_{1}$ were additive [Hnizdo 1992].

Epidemiologic studies of Vermont granite workers provided quantitative predictions of $\mathrm{FEV}_{1}$ loss based on cumulative past exposure to granite dust. As shown in Table 17, the predicted $\mathrm{FEV}_{1}$ loss for Vermont granite workers is 3 to $4 \mathrm{ml}$ per $\mathrm{mg} / \mathrm{m}^{3}$. year for cumulative exposure to granite dust and $2.9 \mathrm{ml}$ per $\mathrm{mg} / \mathrm{m}^{3}$. year for cumulative exposure to quartz dust. This estimate represents a loss of about $6.5 \mathrm{ml}$ of $\mathrm{FEV}_{1}$ for a working lifetime (i.e., 45 years) of exposure to crystalline silica at the current NIOSH REL of $0.05 \mathrm{mg} / \mathrm{m}^{3}$. However, the findings of Theriault et al. [1974b] were based on measurements that may have been inaccurate. In 1979, Graham et al. [1981] administered pulmonary function testing to about $73 \%(n=712)$ of the workers tested in 1974 and found small annual increases in $\mathrm{FEV}_{1}$. These researchers concluded that "technical deficiencies in the previous studies led to exaggerated and erroneous estimates of loss."
The significance of predicted losses can be compared with the annual estimated $\mathrm{FEV}_{1}$ decline for a nonminer who smokes one pack of cigarettes per day (10 ml/year) [Xu et al. 1992] or with the approximate annual $\mathrm{FEV}_{1}$ decrease in men over age 25 (25 to $30 \mathrm{ml} /$ year) [Burrows 1986].

A cross-sectional study of 389 male residents of a U.S. hardrock mining community also predicted $\mathrm{FEV}_{1}$ loss [Kreiss et al. 1989b]. Multiple regression analyses found a significant difference $(P \leq 0.05)$ in the mean $\mathrm{FEV}_{1}$ for nonsmokers with dust exposure $(96 \%$ of predicted $\mathrm{FEV}_{1}$ ) compared with that of nonsmokers without occupational dust exposure (101\% of predicted $\mathrm{FEV}_{1}$ ) [Kreiss et al. 1989b].

\subsubsection{Emphysema}

\subsubsection{Definition}

Emphysema is the abnormal enlargement of the air spaces distal to the terminal bronchiole with destructive changes in the alveolar walls [ATS 1987]. Obvious fibrosis is not present [ATS 1987, 1995; Barnhart 1994; Becklake 1992], although small emphysematous spaces are frequently seen radiographically around the edges of large silicotic masses [Weill et al. 1994]. The diagnosis of emphysema is defined by pathologic criteria, and more recently by the presence of avascular spaces on computed tomographic (CT) scans of the lung [Barnhart 1994; Hayhurst et al. 1984]. Clinical signs include hyperinflation on chest radiographs, increased total lung capacity, reduced $\mathrm{FEV}_{1}$, reduced diffusing capacity for carbon monoxide (DLCO) [Barnhart 1994], and weight loss [Stulbarg and Zimmerman 1996]. Emphysema is caused mainly by destruction of the lung parenchyma from excess proteolytic enzymes. One cause of excess proteolytic enzymes and the premature development of emphysema is the rare homozygous deficiency of the protein $\alpha_{1}$-antitrypsin [Laurell and Eriksson 1963; Stulbarg and Zimmerman 1996]. Excess 


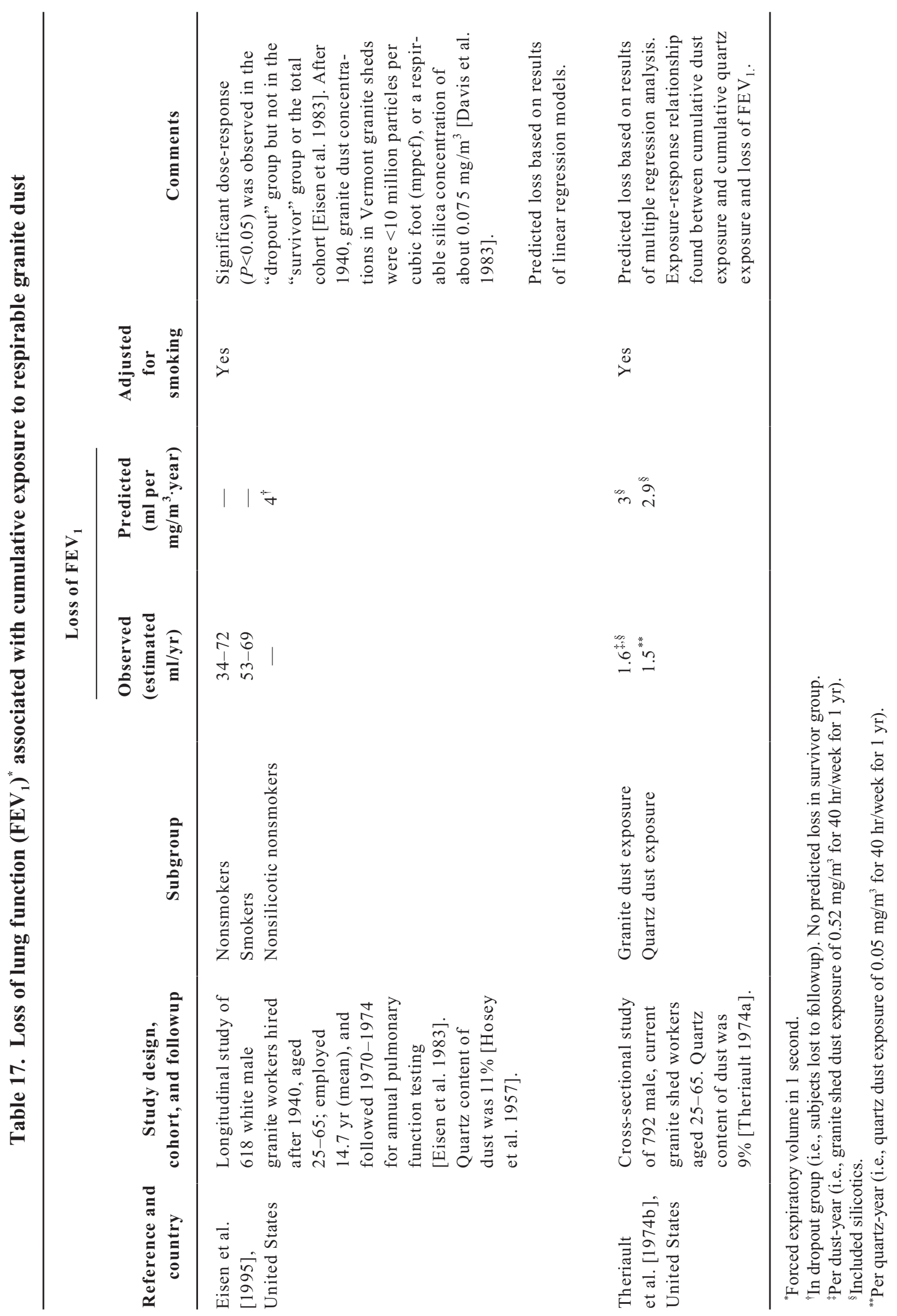


proteolytic enzymes can also occur when there is excessive recruitment of polymorphonuclear leukocytes (e.g., from damage caused by cigarette smoke) [Stulbarg and Zimmerman 1996].

Emphysema is classified microscopically by type based on the distribution of enlarged airspaces and destruction. The main types of emphysema include centriacinar, focal, centrilobular, panacinar, distal acinar, and irregular (scar) [Barnhart 1994; Parkes 1994]. Focal and centrilobular emphysema are the types frequently associated with environmental and occupational exposures. Focal emphysema is associated with exposure to coal dust, and centrilobular emphysema is commonly found in the upper lobes of the lungs of cigarette smokers and others exposed to chronic irritants [Barnhart 1994]. However, findings from a study of postmortem lung examinations showed that panacinar or centriacinar were the predominant types of emphysema found in the lungs of white South African gold miners [Hnizdo et al. 1991].

\subsubsection{Epidemiologic Studies}

Studies of emphysema in silica-exposed workers (excluding coal miners) show conflicting results: it is not clear whether silica exposure is associated with emphysema in all exposed workers or mainly in silica-exposed workers who smoke. In these studies, researchers have investigated cohorts of South African gold miners, usually by combining historical data about occupational exposures and smoking with postmortem examination of the lungs. (Attending physicians in South Africa who know or suspect that their deceased patient was a miner are legally required to remove the cardiorespiratory organs and send them to the Medical Bureau for Occupational Diseases if permission is granted by the next-of-kin [Goldstein and Webster 1976]).
Of the five studies presented in Table 18, one found that a significant relationship $(P<0.05)$ independent of smoking and silicosis existed between gold mine dust exposure ${ }^{* *}$ and emphysema [ et al. 1987]. Two studies found no relationship between emphysema and years of mining [Chatgidakis 1963; Cowie et al. 1993]. A study of emphysema type in 1,553 miners with autopsy examinations found that centriacinar emphysema was more common in smokers, whereas panacinar emphysema was more common in nonsmokers; exposure to gold mine dust was related to both types. A miner who had worked 20 years in high-dust occupations was 3.5 times more likely $(95 \% \mathrm{CI}=$ 1.7-6.6) to have emphysema (i.e., an emphysema score $\geq 30 \%$ ) at autopsy than a miner who did not have a dusty occupation. However, the authors stated that this result was likely to "be true of smoking miners only because there were only four nonsmokers with an emphysema score between $30 \%$ and $40 \%$ " [Hnizdo et al. 1991]. Later, a study of 242 miners who were lifelong nonsmokers found that the severity of emphysema at autopsy was not related to most recent lung function measurements or to years of gold mining, cumulative dust exposure, or parenchymal silicosis after adjustment for age at death [Hnizdo et al. 1994]. All of the studies but two [Becklake et al. 1987; Hnizdo et al. 1994] found that the presence of emphysema was significantly associated with silicosis.

\subsubsection{Nonmalignant Respiratory Disease (NMRD) Mortality}

Epidemiologic studies of silica-exposed workers [Checkoway et al. 1993, 1997; Chen et al. 1992; Cherry et al. 1998; Brown et al. 1986; Costello and Graham 1988; Costello et al. 1995;

\footnotetext{
${ }^{* *}$ The number of shifts worked in mining occupations with high dust exposure.
} 


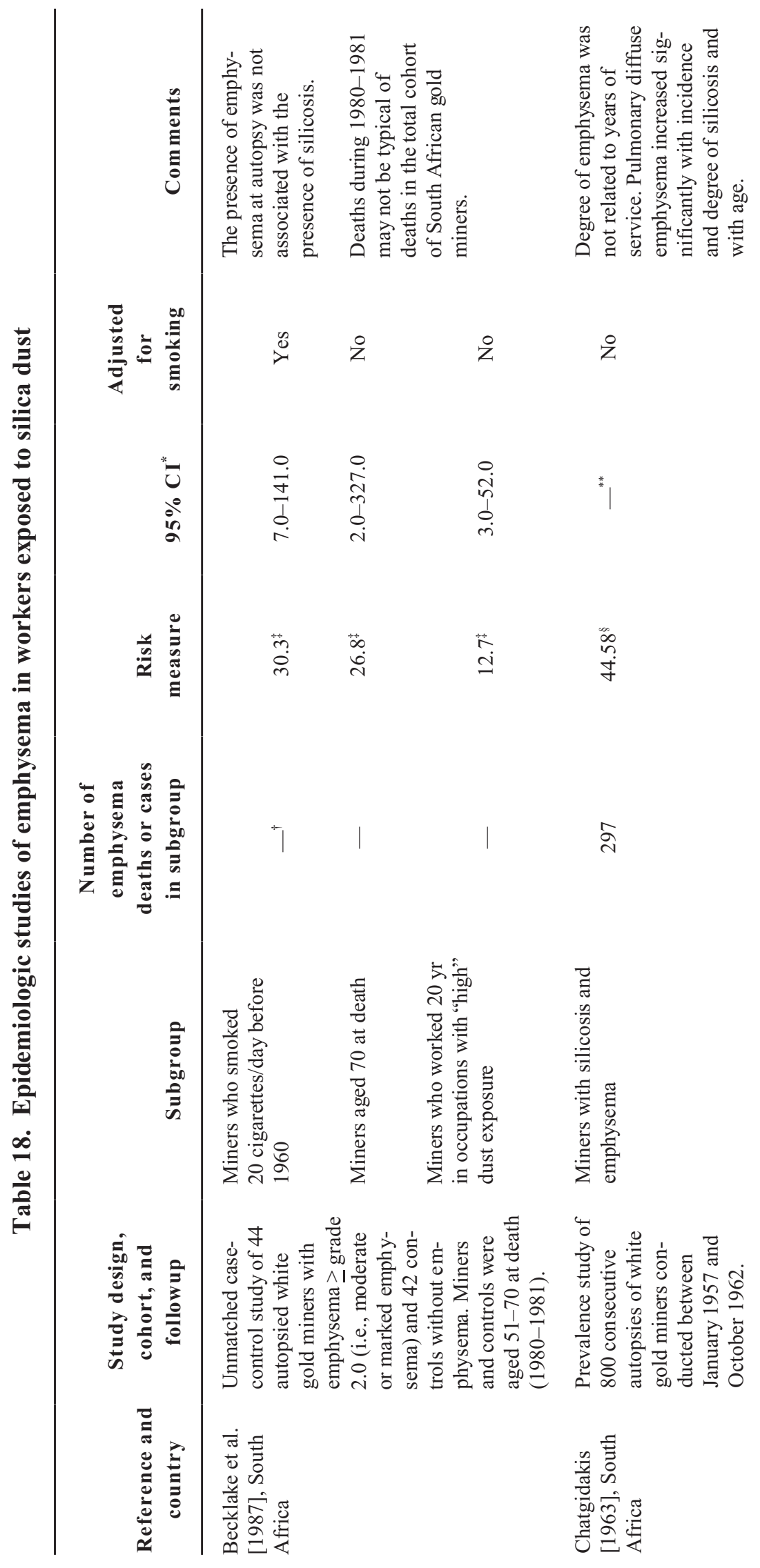




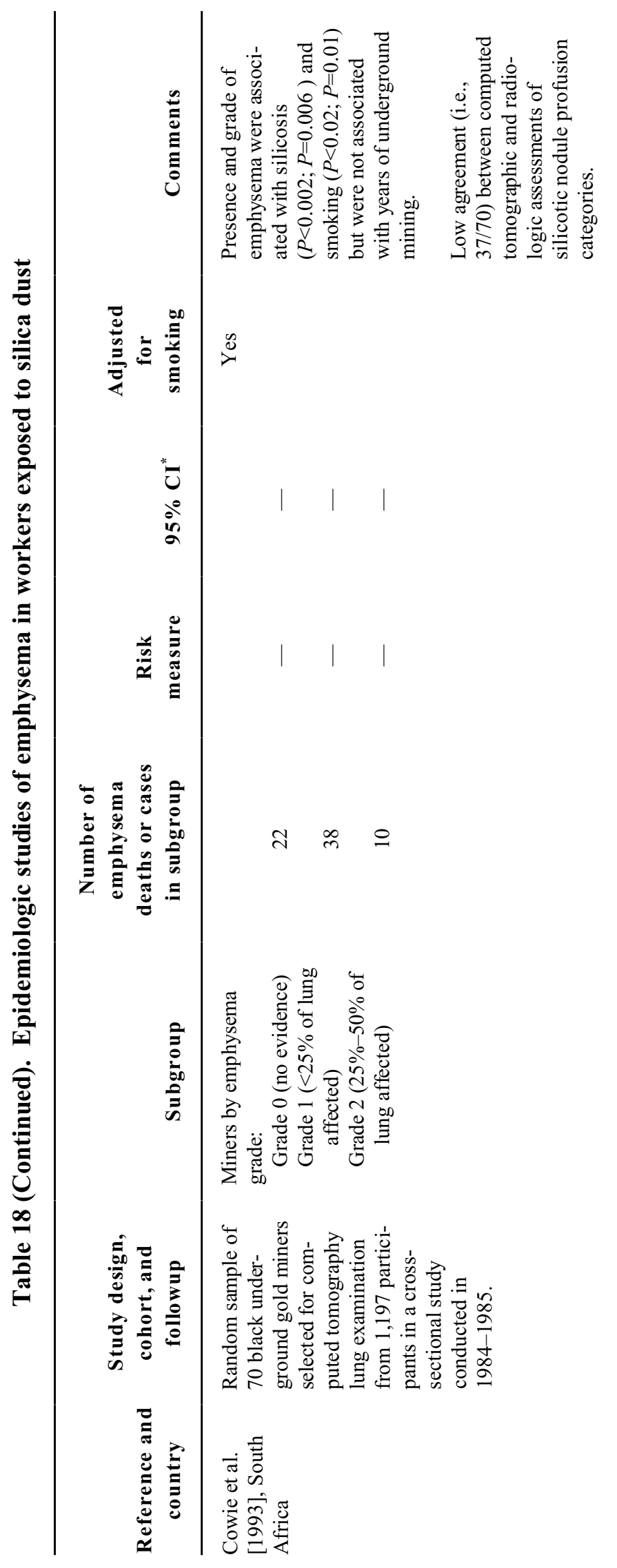




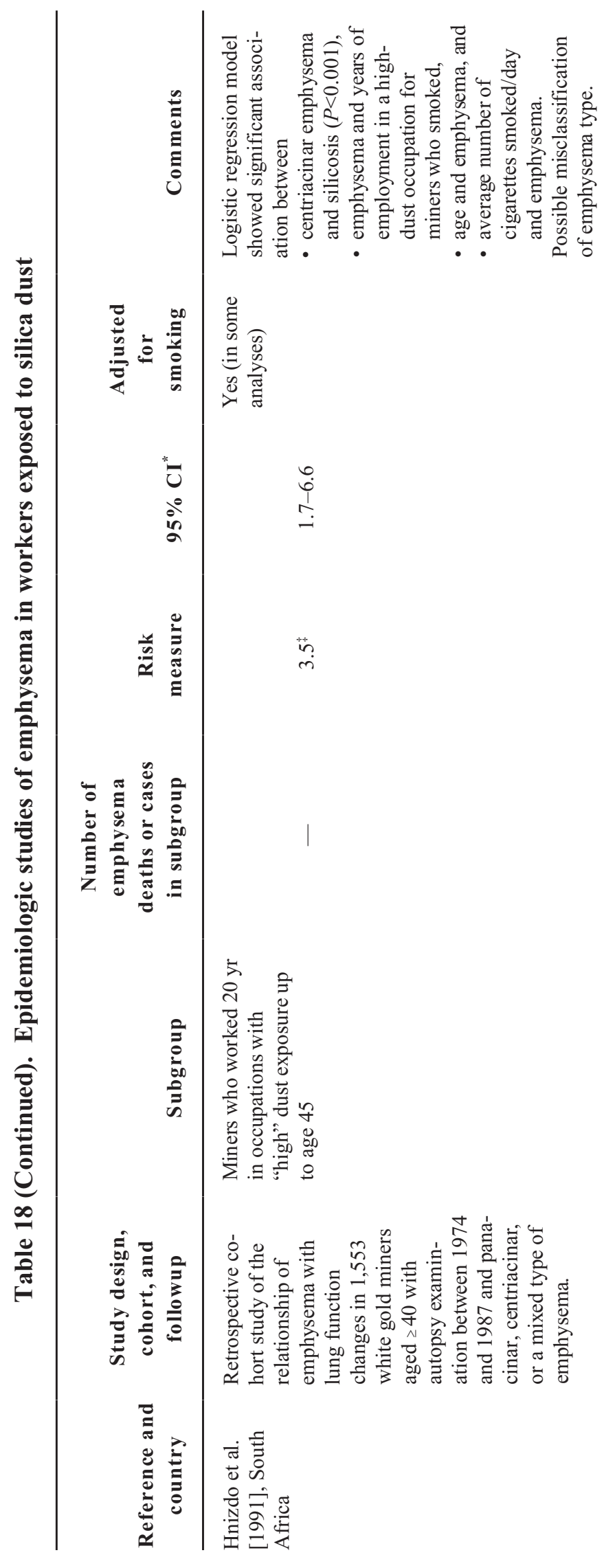




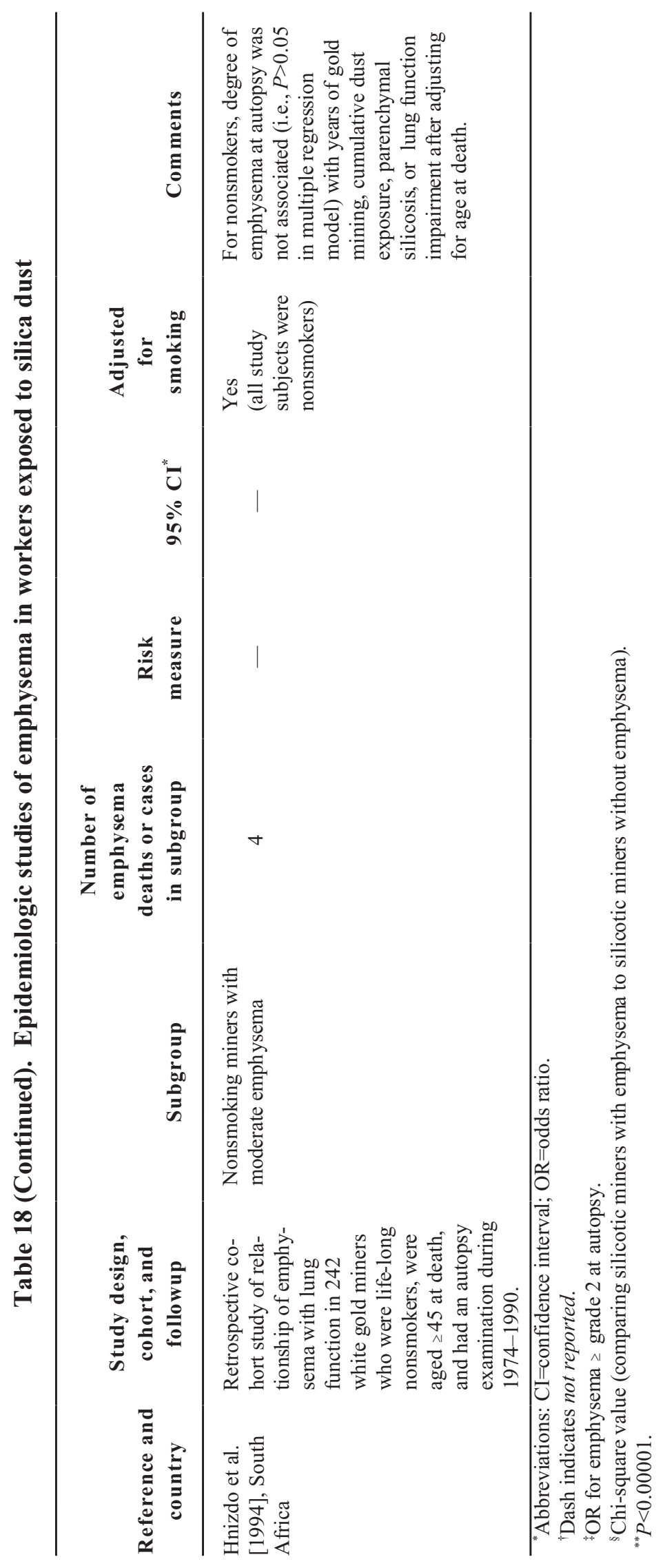


Costello 1983; Steenland and Brown 1995b; Steenland and Beaumont 1986; Thomas and Stewart 1987; Thomas 1990] and silicotics [Goldsmith et al. 1995; Brown et al. 1997; Rosenman et al. 1995] found significant increases in mortality from NMRD, a broad category that can include silicosis and other pneumoconioses, chronic bronchitis, emphysema, asthma, and other related respiratory conditions.

The studies of U.S. gold miners [Steenland and Brown 1995b], U.S. diatomaceous earth workers [Checkoway et al. 1993, 1997], silicotic men in Sweden and Denmark [Brown et al. 1997] and parts of the United States [Rosenman et al. 1995], and U.S. pottery workers [Thomas and Stewart 1987] reported mortality ratios (SMRs or PMRs) for some categories of NMRD. However, the other studies either did not report SMRs for categories of NMRD or did not separate silicosis deaths from other categories of NMRD, thus limiting any conclusion about the association of silica exposure with death from a specific COPD based on death certificate data.

Some studies have reported exposure-response trends for NMRD and silica exposure. The study of diatomaceous earth workers found a statistically significant exposure-response trend for cumulative exposure to respirable crystalline silica and NMRD mortality after adjustment for the effects of age, calendar year, duration of followup, and ethnicity (rate ratio $=5.35$ in the highest exposure stratum $\left[\geq 5.0 \mathrm{mg} / \mathrm{m}^{3} \cdot\right.$ year $] ; 95 \% \quad \mathrm{CI}=2.23-12.80$; 15-year exposure lag) [Checkoway et al. 1997]. Other studies found exposure-response trends for NMRD mortality and duration of employment [Costello et al. 1995; Thomas and Stewart 1987], years since first exposure [Thomas and Stewart 1987], or qualitative categories of silica exposure (none, low, and high) [Thomas and Stewart 1987].

\subsection{Autoimmune and Chronic Renal Diseases}

In this century, many published case reports have described various autoimmune disorders in workers or patients who were occupationally exposed to crystalline silica [Bramwell 1914; Erasmus 1957; Jones et al. 1976; Mehlhorn 1984; Mehlhorn et al. 1990a; de Bandt et al. 1991; Yanez Diaz et al. 1992; Pelmear et al. 1992; Caux et al. 1991; Cointrel et al. 1997; Yamamoto et al. 1994; Guseva 1991; Ebihara 1982; Agarwal et al. 1987; Koeger et al. 1991, 1992, 1995; Anandan et al. 1995; Sanchez-Roman et al. 1993; Aoki et al. 1988; Fukata et al. 1983, 1987; Muramatsu et al. 1989; Masuda 1981; Tokumaru et al. 1990; Perez Perez et al. 1986; Bernardini and Iannaccone 1982; Siebels et al. 1995; Suratt et al. 1977; Meyniel et al. 1981; Hatron et al. 1982; Masson et al. 1997; Özoran et al. 1997; Haustein 1998; Cledes et al. 1982; Mehlhorn and Gerlach 1990]. The most frequently reported autoimmune diseases were scleroderma, systemic lupus erythematosus (lupus), rheumatoid arthritis, autoimmune hemolytic anemia [Muramatsu et al. 1989], and dermatomyositis or dermatopolymyositis [Robbins 1974; Koeger et al. 1991]. Case reports have also described health effects such as the following that may be related to the immunologic abnormalities in patients with silicosis: chronic renal disease [Saita and Zavaglia 1951; Bolton et al. 1981; Giles et al. 1978; Pouthier et al. 1991; Neyer et al. 1994; Dracon et al. 1990; Sherson and Jorgensen 1989; Rispal et al. 1991; Osorio et al. 1987; Bonnin et al. 1987; Arnalich et al. 1989; Wilke et al. 1996; Banks et al. 1983; Hauglustaine et al. 1980; Slavin et al. 1985], ataxic sensory neuropathy [Tokumaru et al. 1990], chronic thyroiditis [Masuda 1981], hyperthyroidism (Graves' disease) [Koeger et al. 1996], monoclonal gammopathy [Fukata et al. 1983, 1987; Aoki et al. 1988], and polyarteritis nodosa [Arnalich et al. 1989]. 
In addition to these case reports, 13 post- 1985 epidemiologic studies reported statistically significant numbers of excess cases or deaths from known autoimmune diseases or immunologic disorders (scleroderma, systemic lupus erythematosus, rheumatoid arthritis, and sarcoidosis), chronic renal disease, and subclinical renal changes (Table 19). Epidemiologic studies found statistically significant associations between occupational exposure to crystalline silica dust and several renal diseases or effects, including end-stage renal disease morbidity [Steenland et al. 1990], morbidity from end-stage renal disease caused by glomerulonephritis [Calvert et al. 1997], chronic renal disease mortality [Steenland and Brown 1995b], Wegener's granulomatosis (systemic vasculitis often accompanied by glomerulonephritis) [Nuyts et al. 1995], and subclinical renal changes [Hotz et al. 1995; Boujemaa et al. 1994; Ng et al. 1992a, 1993].

The pathogenesis of glomerulonephritis and other renal effects in silica-exposed workers is not clear. Some case reports provide evidence of an immunologic injury by immune complex formation, and other reports point to a direct toxic effect of silica [Calvert et al. 1997; Calvert and Steenland 1997; Kallenberg 1995; Wilke et al. 1996; Wilke 1997]. The immunologic aspects of renal disease are reviewed in Ambrus and Sridhar [1997].

The cellular mechanism that leads from silica exposure to autoimmune diseases is not known [Otsuki et al. 1998]. One theory is that when respirable silica particles are encapsulated by macrophages, fibrogenic proteins and growth factors are generated, and ultimately the immune system is activated [Haustein and Anderegg 1998; Ziegler and Haustein 1992; Haustein et al. 1992]. Immune activation by respirable crystalline silica may be linked to scleroderma, rheumatoid arthritis, polyarthritis, mixed connective tissue disease, systemic lupus erythematosus, Sjögren's syndrome, polymyositis, and fibrositis [Ziegler and Haustein 1992; Haustein et al. 1990; Otsuki et al. 1998]. A possible mechanism for development of scleroderma is a direct local effect of nonrespirable quartz particles that have penetrated the skin of workers [Green and Vallyathan 1996], as observed in skin samples from deceased scleroderma patients [Mehlhorn et al. 1990b].

In addition to the studies summarized in Table 19, there may be other epidemiologic data sets that have not been analyzed by methods that would detect a possible association between occupational exposure to crystalline silica and autoimmune diseases [Steenland and Goldsmith 1995]. Further clinical and immunologic studies are needed to characterize the relationship between occupational exposure to crystalline silica and autoimmune diseases.

\subsection{Other Health Effects}

Extrapulmonary deposits of silica have been reported. A review of the literature [Slavin et al. 1985] indicates that silica particles may be transported from the lungs and tracheobronchial lymph nodes to the spleen, liver, kidneys [Osorio et al. 1987], bone marrow, and extrathoracic lymph nodes as a result of (1) formation of silicotic lesions in pulmonary veins, (2) erosion of silicotic hilar nodules into pulmonary veins, and (3) rupture of silicotic nodules into the lymphatic system. Roperto et al. [1995] reported two cases of extrapulmonary silicosis in two water buffaloes that lived on a farm near a quartz quarry. Silicotic lesions were observed in the mesenteric lymph nodes, tonsils, and spleen. In humans with occupational exposure to silica, peritoneal silicosis has been misdiagnosed as pancreatic carcinoma [Tschopp et al. 1992] or abdominal malignancy [Miranda et al. 1996].

Intravenous injections of silica into the tail veins of rats have resulted in large liver 


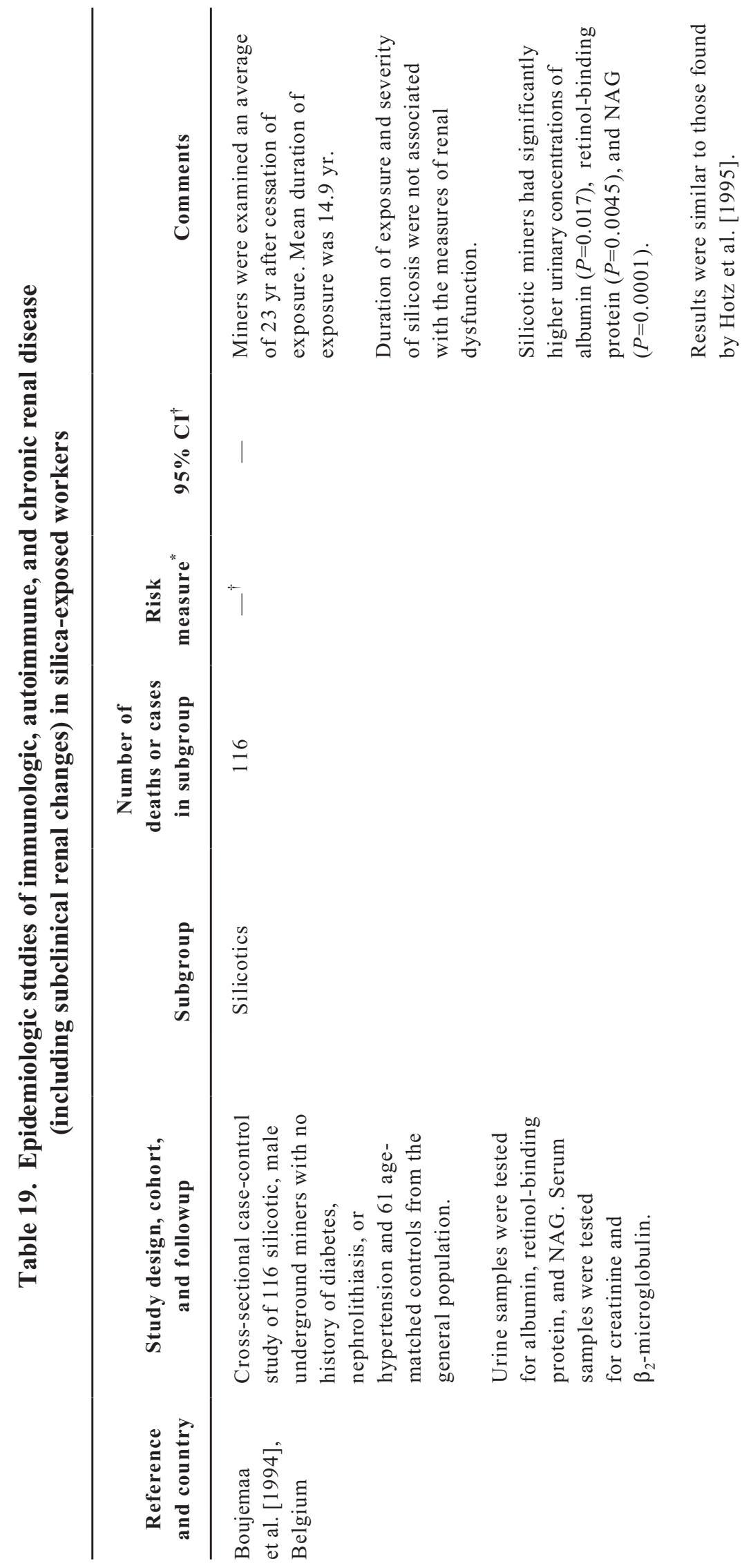




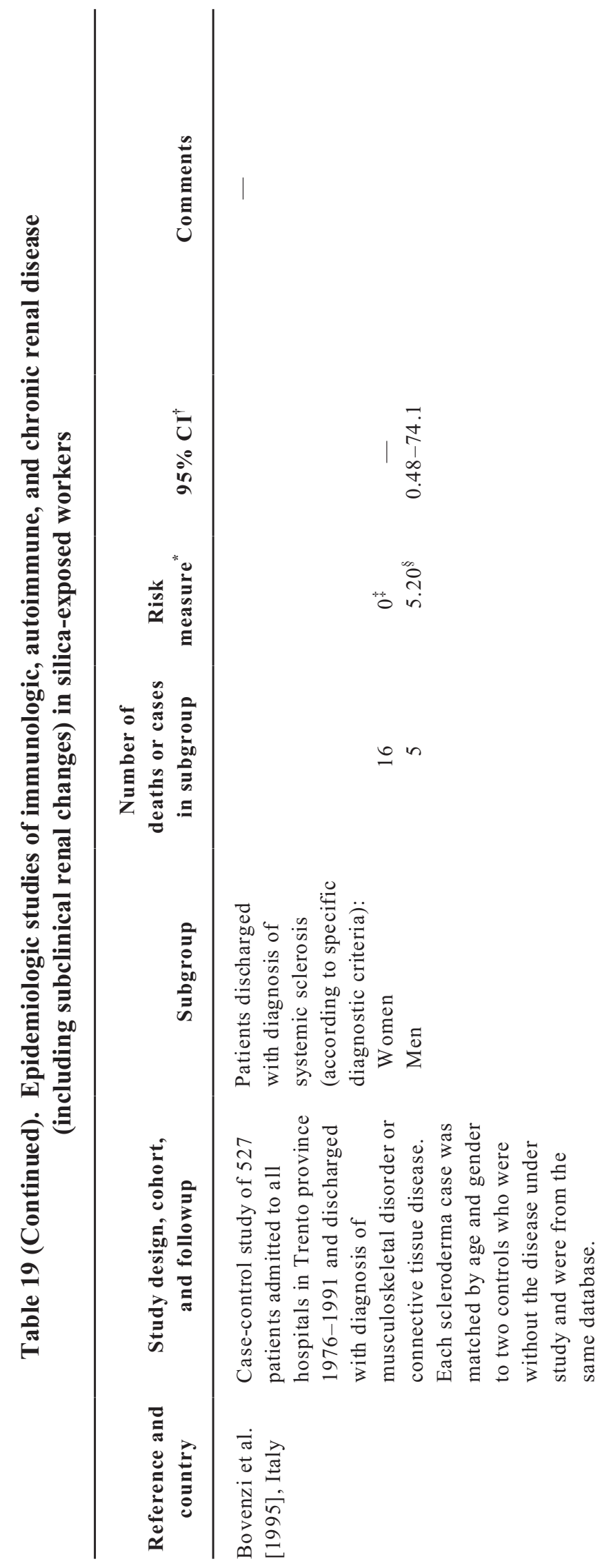




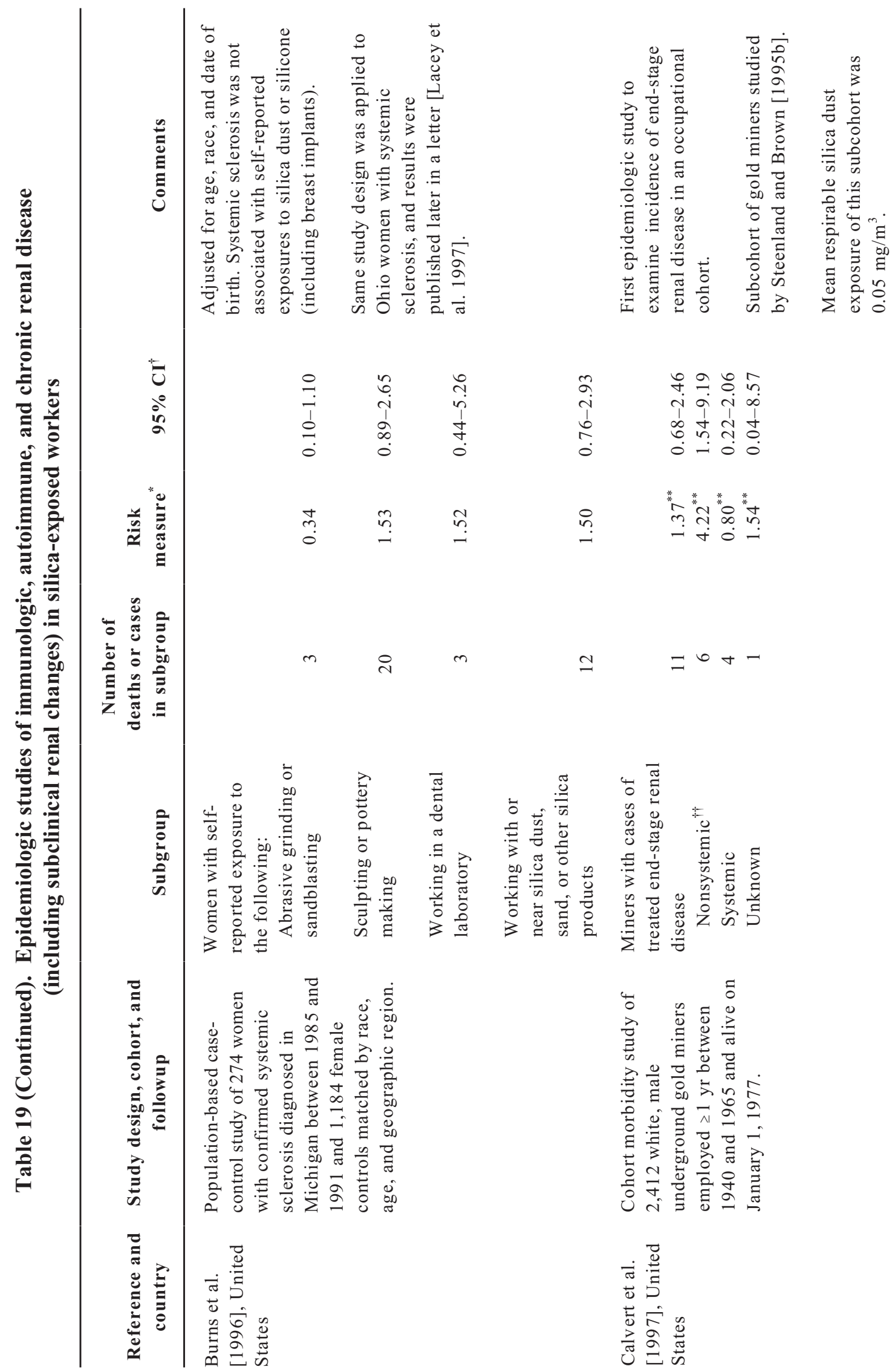




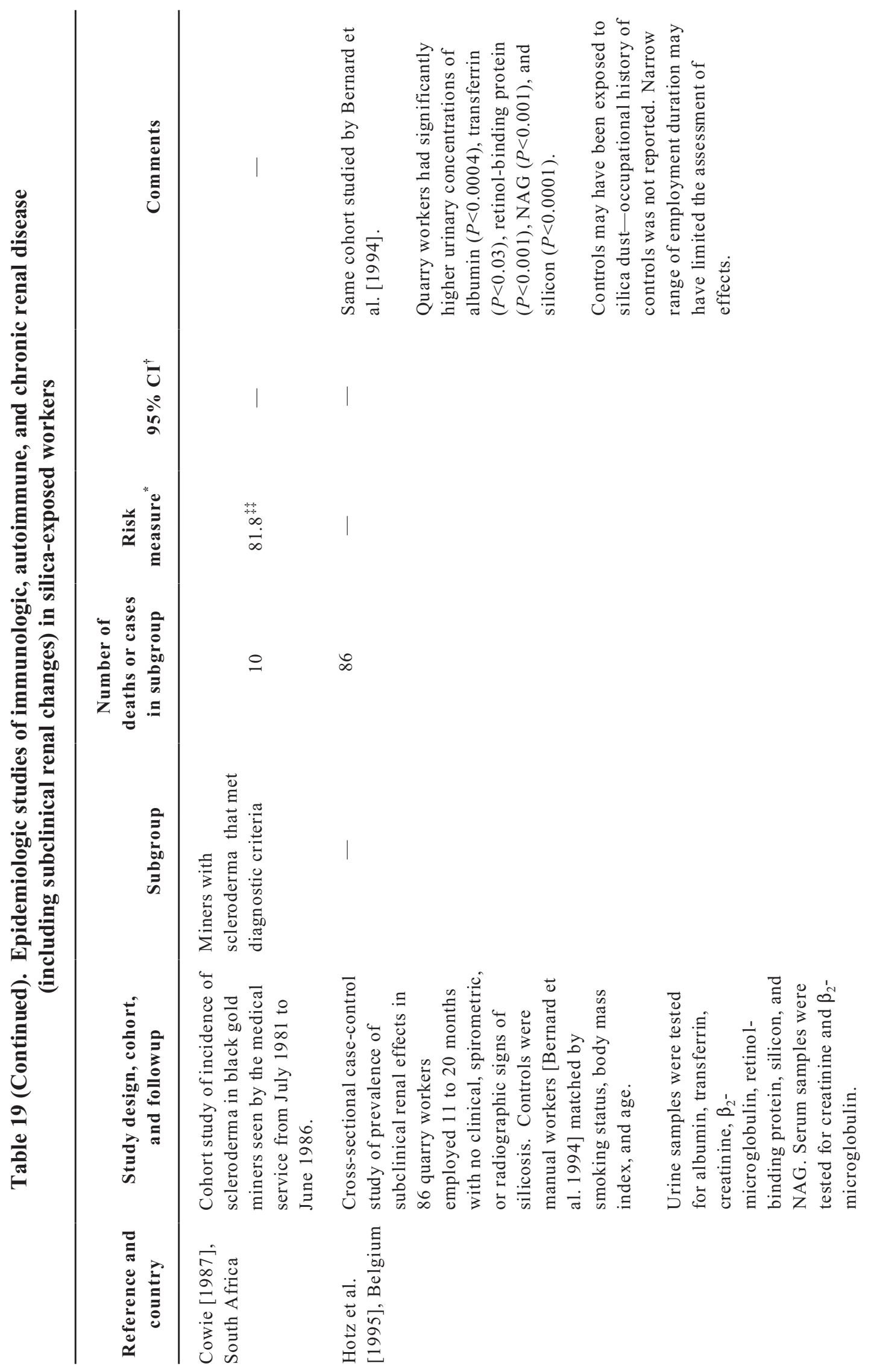




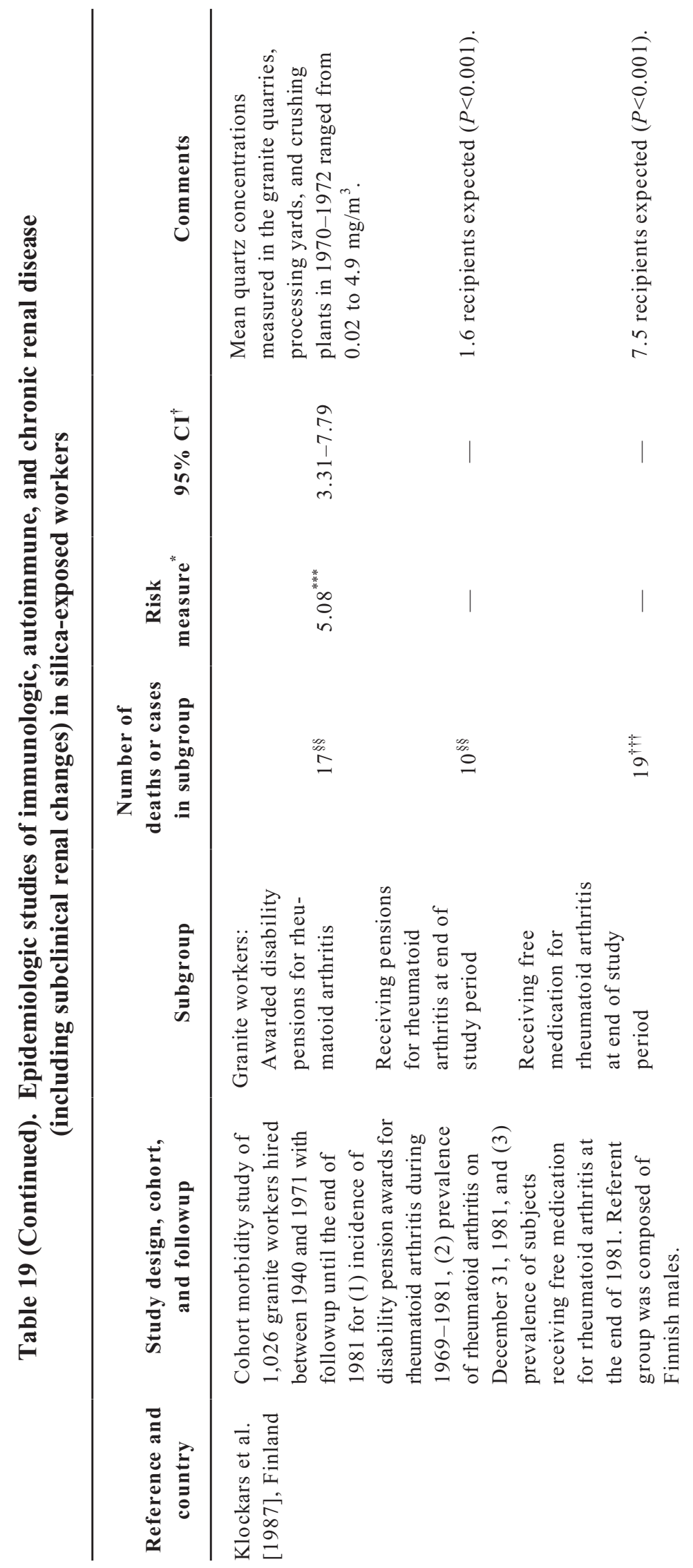




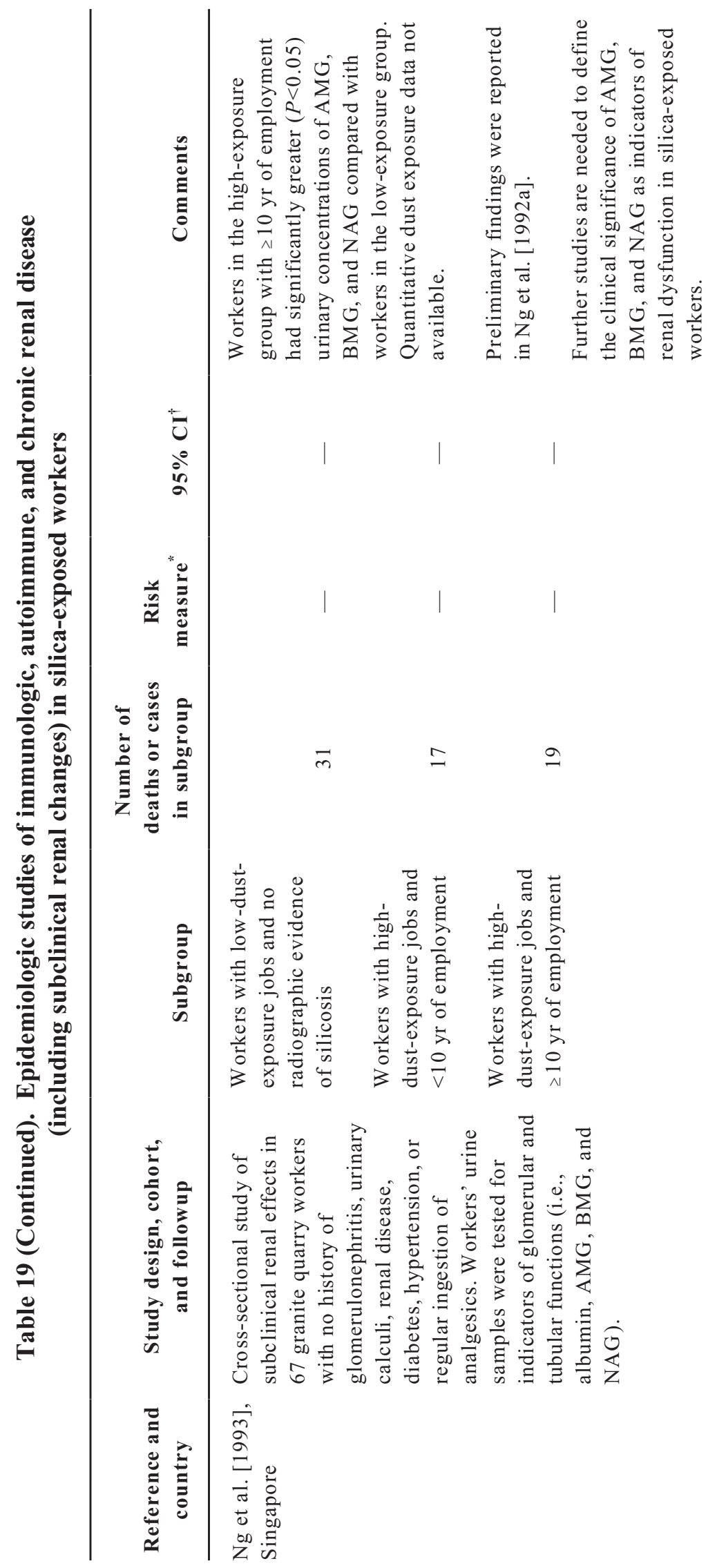




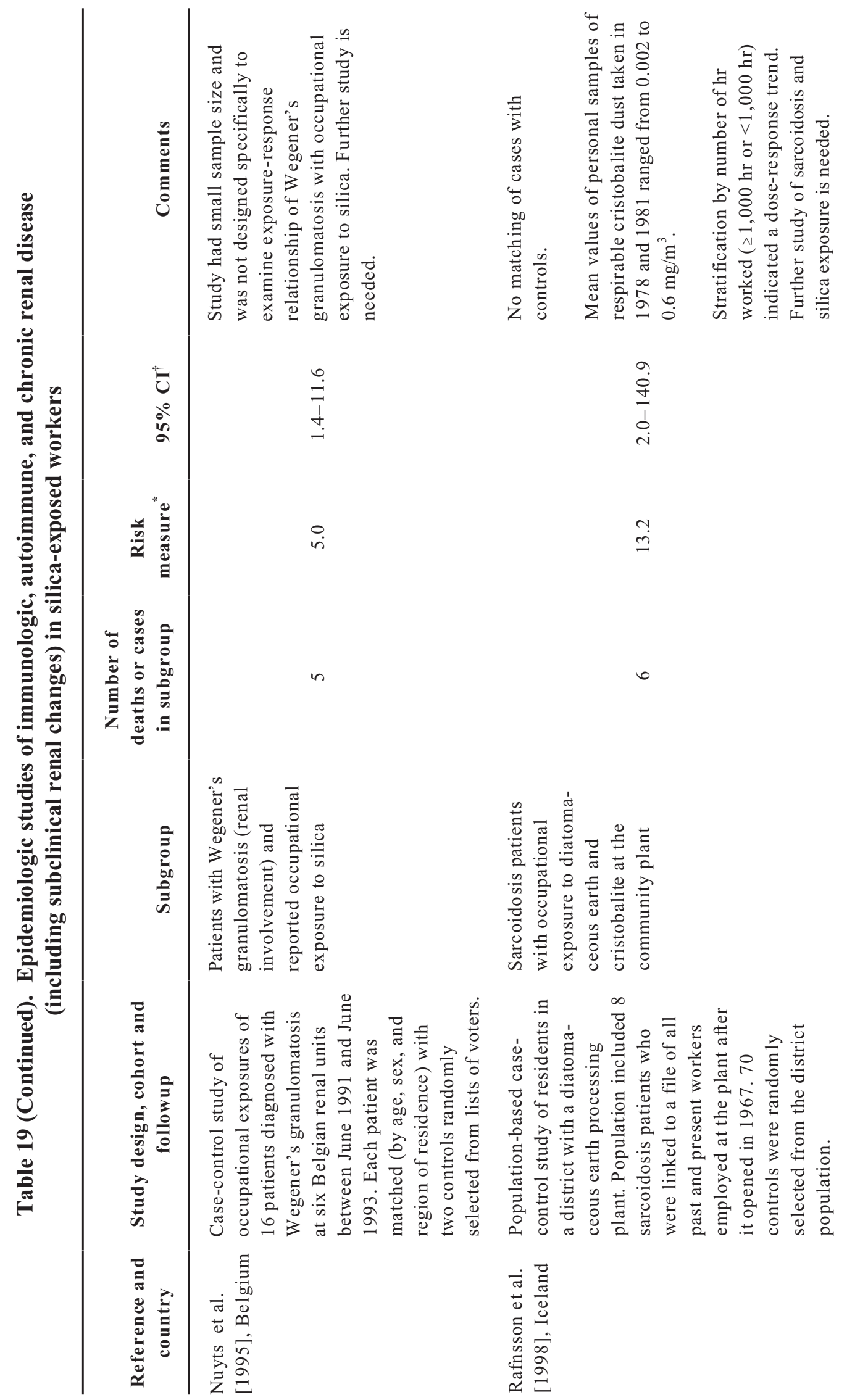




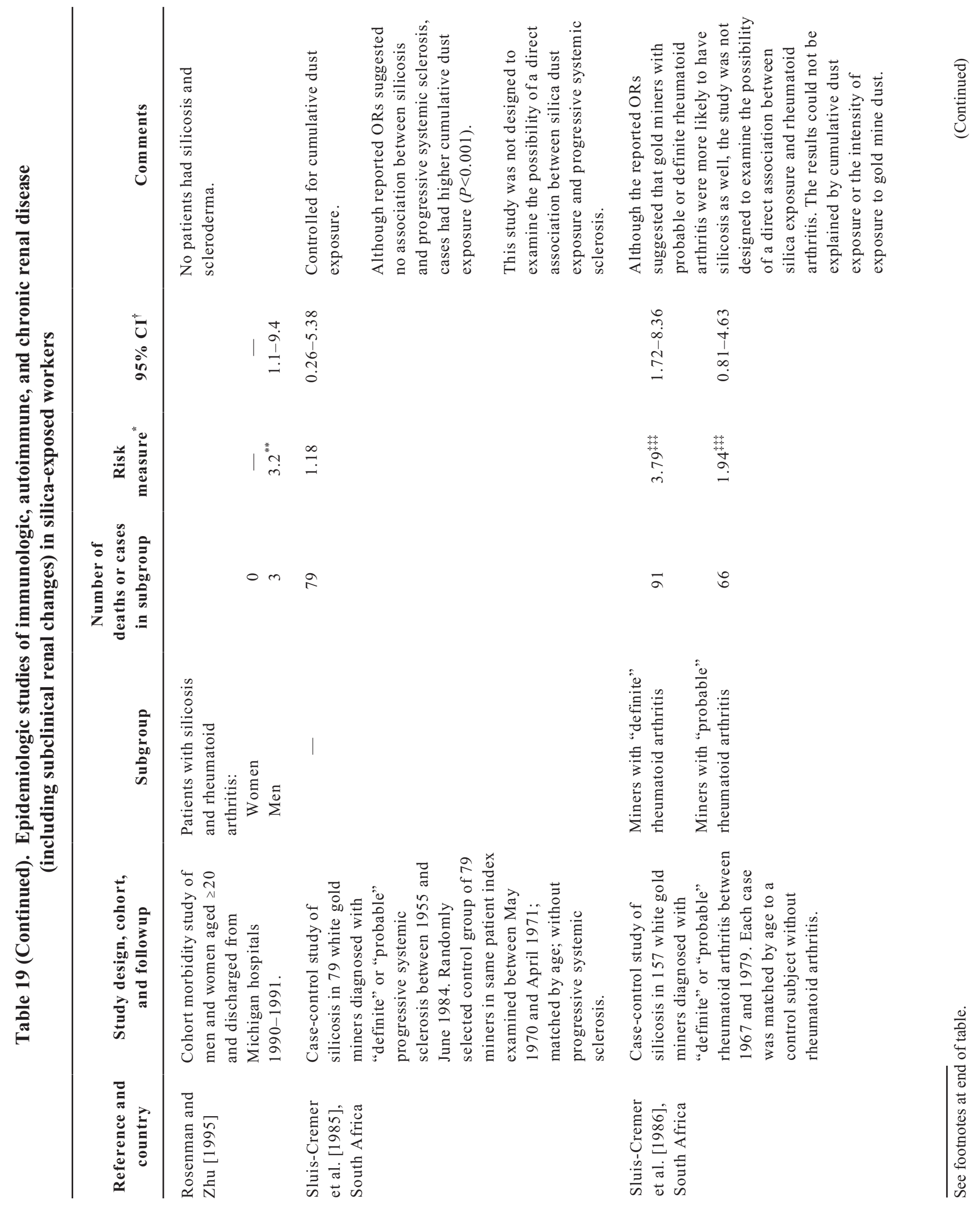




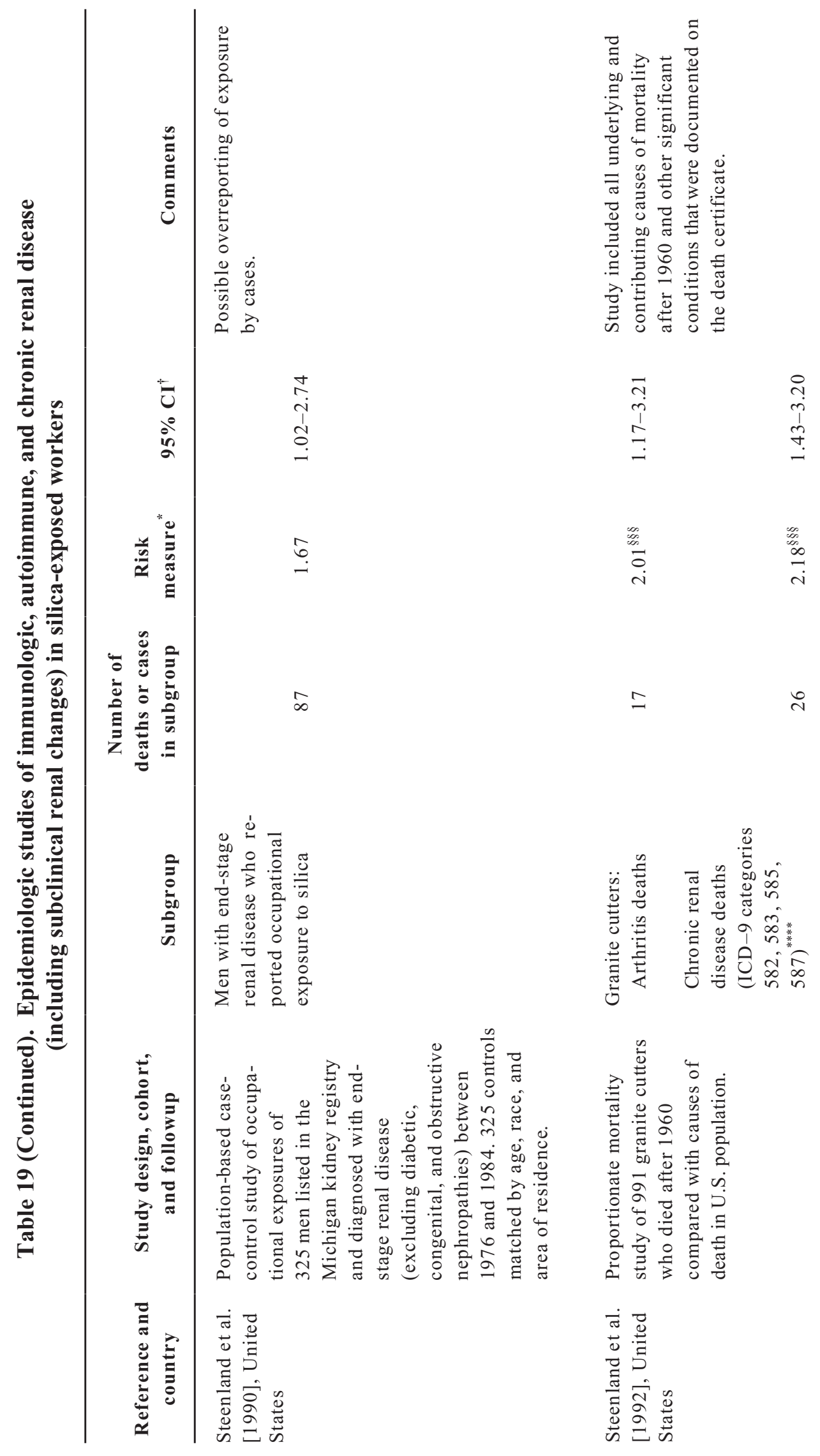




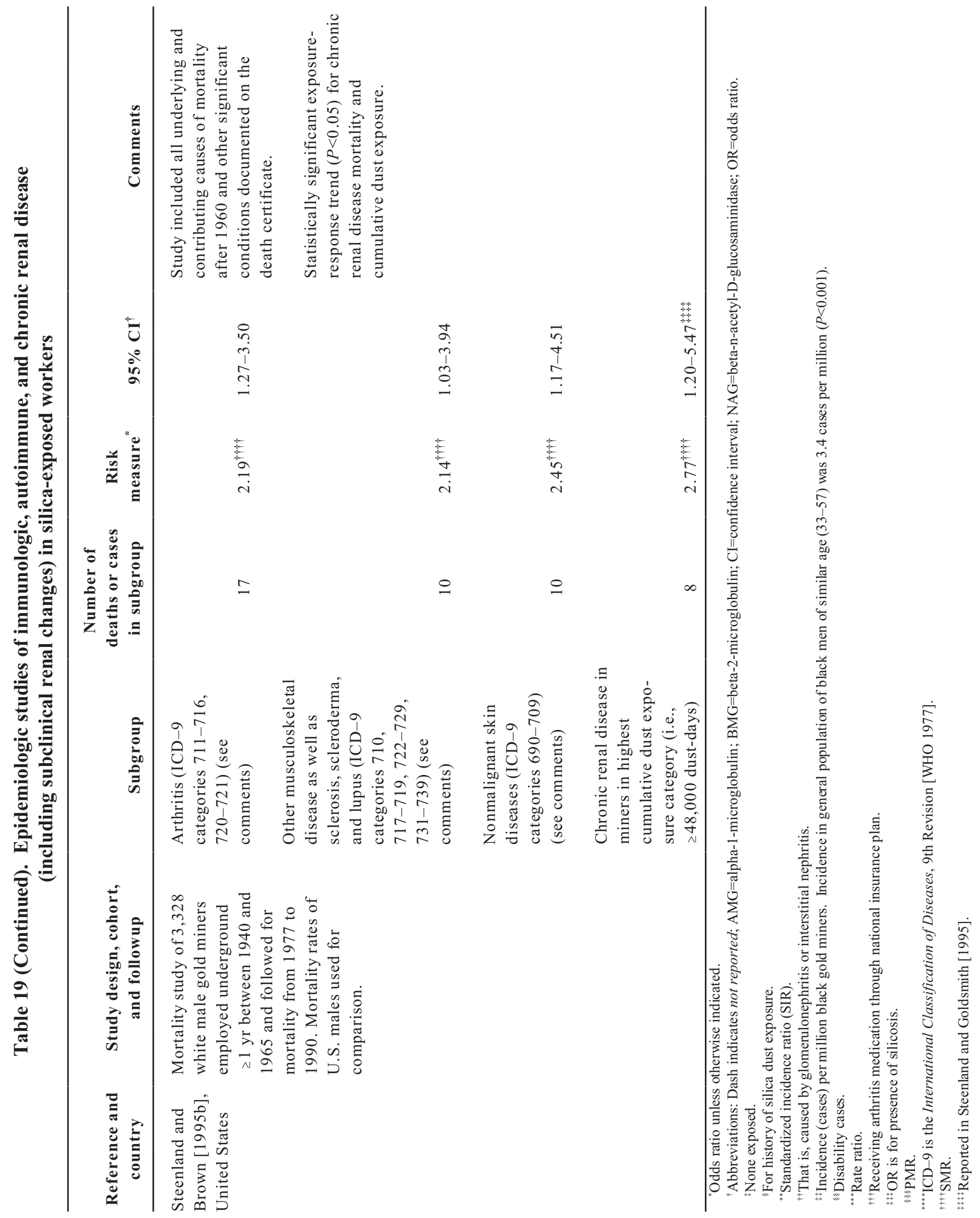


granulomas and hepatic silicosis [Kanta et al. 1986]. In workers exposed to crystalline silica, hepatic changes [Liu et al. 1991], hepatic or hepatosplenic silicosis [Clementsen et al. 1986; Oswald et al. 1995], and hepatocellular carcinoma [Clementsen et al. 1986] have been identified. Two studies reported a significantly higher proportion $(P<0.05)$ of symptomatic hepatic porphyria (a chronic metabolic disease) in silica-exposed workers compared with control groups having no history of occupational silica exposure [Okrouhlílik and Hykeš 1983; Zoubek and Kordac 1986]. However, the effect of silica on porphyrin synthesis and metabolism is not clear. In one study, alcohol consumption (quantity not specified) may have been a confounder [Okrouhlílik and Hykeš 1983].

Mowry et al. [1991] reported a case of a cutaneous silica granuloma in a 57-year-old stonemason. Silica granulomas are firm, nontender dermal or subcutaneous nodules that usually appear at least several years (mean $=10$ years) after the exposure to silica. They may appear as a result of occupational exposure or trauma [Kuchemann and Holm 1979; Murphy et al. 1997] and are usually treated by excision. The mechanism that causes the silica crystals in the tissue to form a granuloma is unknown.

Cor pulmonale (enlargement of the right ventricle of the heart because of structural or functional abnormalities of the lungs) may occur as a complication of silicosis [Green and Vallyathan 1996] and other pneumoconioses [Kusiak et al. 1993a]. This condition is usually preceded by pulmonary arterial hypertension. An epidemiologic case-control study of 732 white South African autopsied gold miners reported a statistically significant association $(P<0.05)$ of cor pulmonale with "extensive" and "slight" silicosis [Murray et al. 1993].

Pulmonary alveolar proteinosis is a rare respiratory disease identified by an accumulation of phospholipid material in the alveoli [McCunney and Godefroi 1989]. Cases of this disease were identified in a U.S. cement truck driver [McCunney and Godefroi 1989], a U.S. sandblaster [Abraham and McEuen 1986], and a French ceramics worker [Roeslin et al. 1980]. Each worker had been potentially exposed to crystalline silica.

Skin absorption of crystalline and amorphous silica particles from soil, and subsequent obstructive lymphopathies related to the fibrogenic effects of the particles may be related to the development of nonfilarial tropical elephantiasis (podoconiosis) in the lower legs of residents of East Africa and certain volcanic areas [Frommel et al. 1993; Fyfe and Price 1985; Price and Henderson 1981].

Silica dust exposure may be associated with abrasion-related deterioration of dental health. Petersen and Henmar [1988] reported a 100\% prevalence of dental abrasion in a group of 33 Danish granite workers. The authors recommended that dust concentrations be reduced, that workers wear face guards, and that dental abrasion from occupational dust exposure be considered an occupational disease. 


\section{Experimental Studies}

This section provides an abbreviated review of various experimental research studies. The reader is encouraged to consult the cited materials for complete information.

\subsection{Biomarkers}

A biomarker can indicate (1) the occurrence of exposure, (2) the effects of exposure, (3) the presence of early or frank disease, or (4) the susceptibility to disease or early effects of exposure [Committee on Biological Markers of the National Research Council 1987; Schulte 1995]. Useful biomarkers require (1) a definitive, validated link with the exposure or the risk of disease and (2) evidence of a doseresponse relationship between the marker and the exposure [Schulte 1995]. The relationship between respirable silica dust exposure and silicosis is well established. However, the complex chain of cellular responses that leads to fibrosis and silicosis has not been fully discovered. The usefulness of biomarkers as a screening tool for silicosis risk will be realized when biomarkers in the chain of complex cellular responses are validated for their relationship to disease. In addition, the studies of blood, serum, sputum, bronchoalveolar lavage samples, and gene patterns of silicaexposed workers or silicotics (Table 20) are inconclusive for the following reasons:

1. The numbers of subjects are small, and few studies of similar markers exist for comparison.

2. The studies lack control for factors other than silica exposure that could change immunoglobulin concentrations.
3. The studies lack information about control groups, diagnostic criteria for silicosis, and baseline levels of markers.

4. Study results are inconsistent.

Further research on biomarkers in silicaexposed workers is needed to do the following:

1. Quantify the exact amount of soluble products in bronchoalveolar lavage in individual patients to provide more information about the mechanisms of fibrogenesis [Sweeney and Brain 1996]

2. Determine whether silicosis or silica-related lung cancers are associated with a specific gene or gene pattern

3. Determine whether a relationship exists between changes in immunoglobulin concentrations and silica exposure

4. Determine whether a dose-response relationship exists between changes in certain cellular components (lymphocytes and Clara cell protein) and silica exposure

Detailed reviews of the immunologic response to silica and other mineral dusts are available elsewhere (i.e., Heppleston [1994]; Haslam [1994]; Weill et al. [1994]; Davis [1991,1996]; Kane [1996]; Driscoll [1996]; Sweeney and Brain [1996]; Hook and Viviano [1996]; Gu and Ong [1996]; Iyer and Holian [1996]; Weissman et al. [1996]; Mossman and Churg [1998]). 


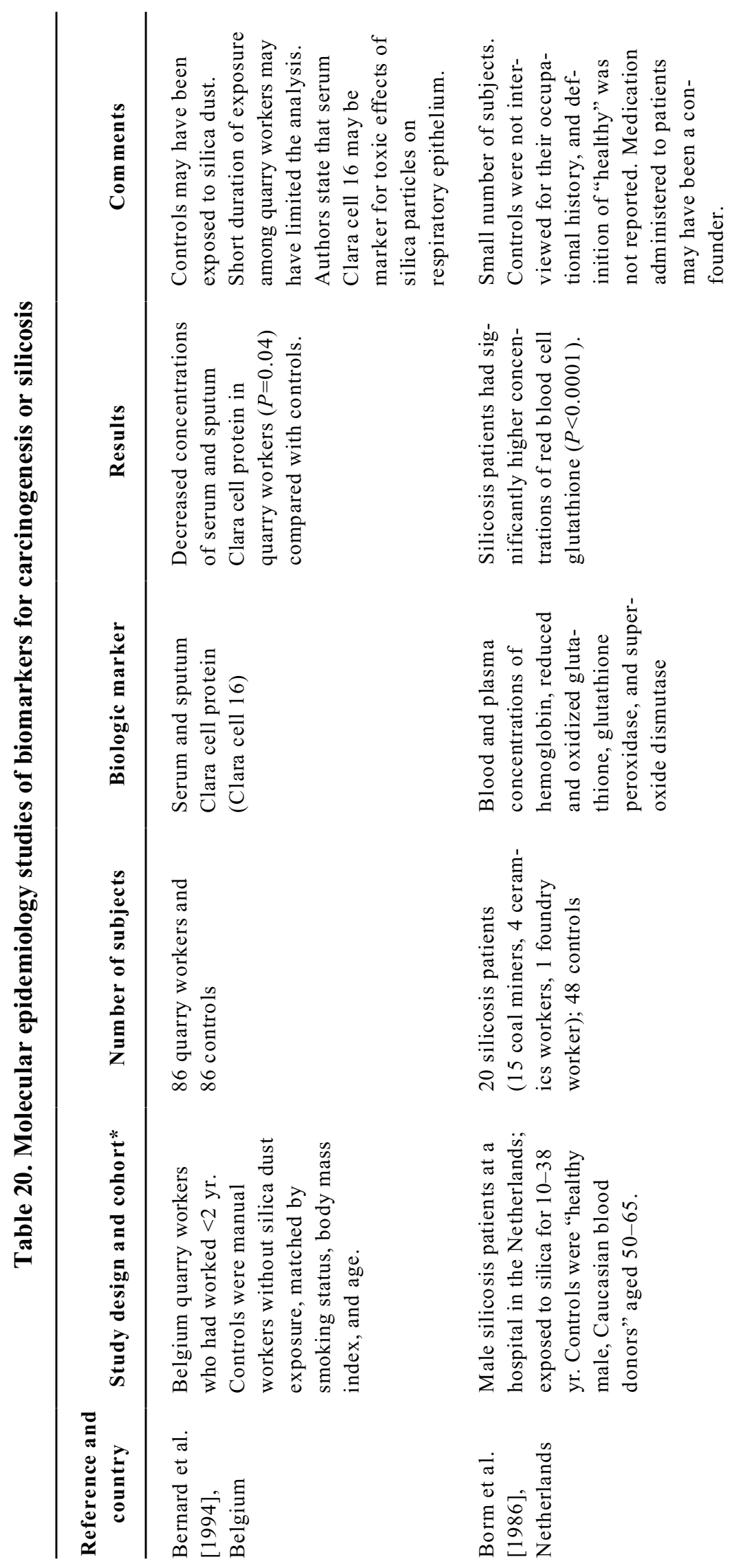




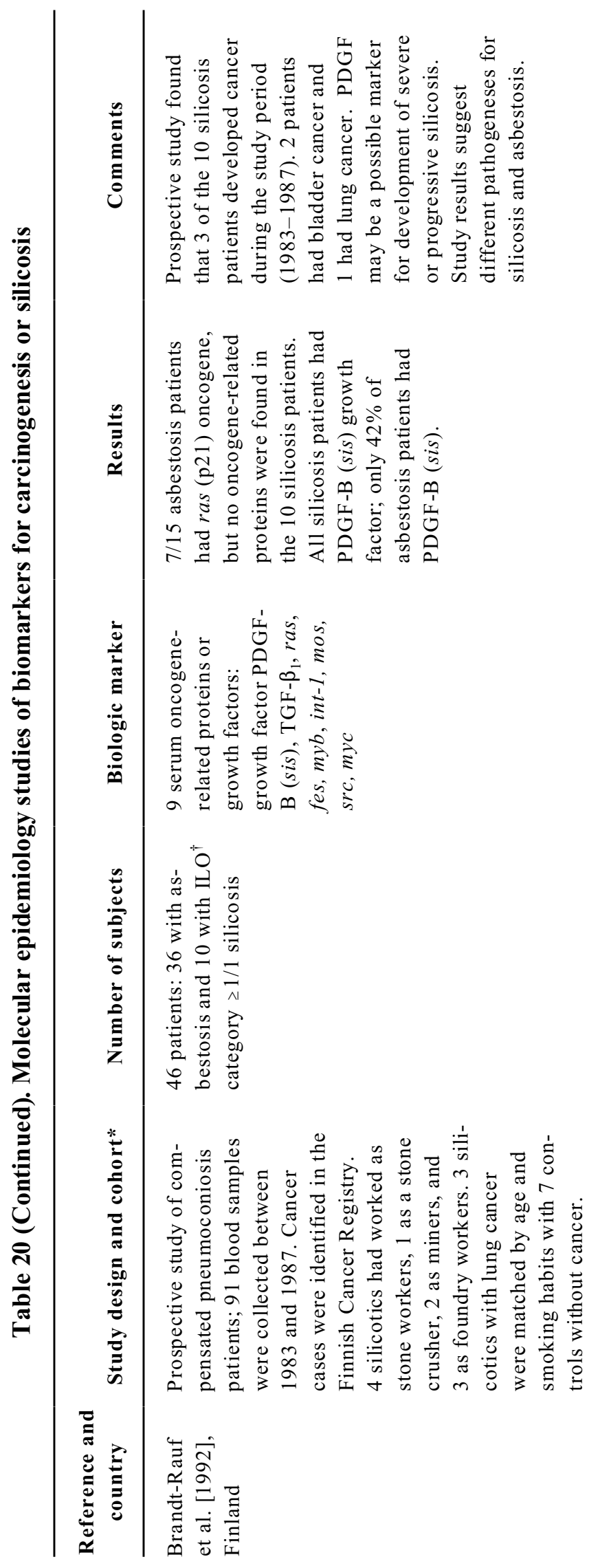




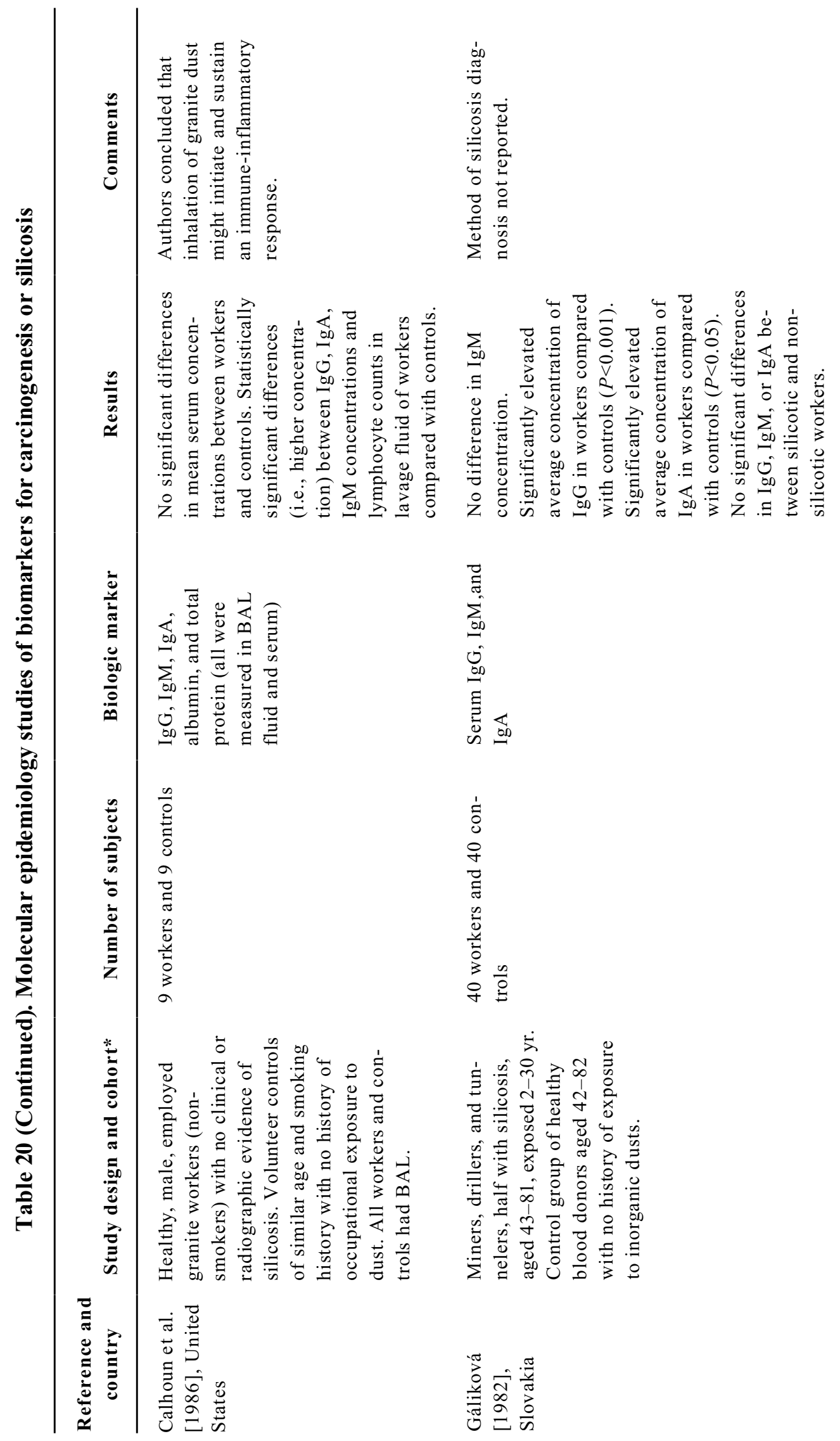

I 


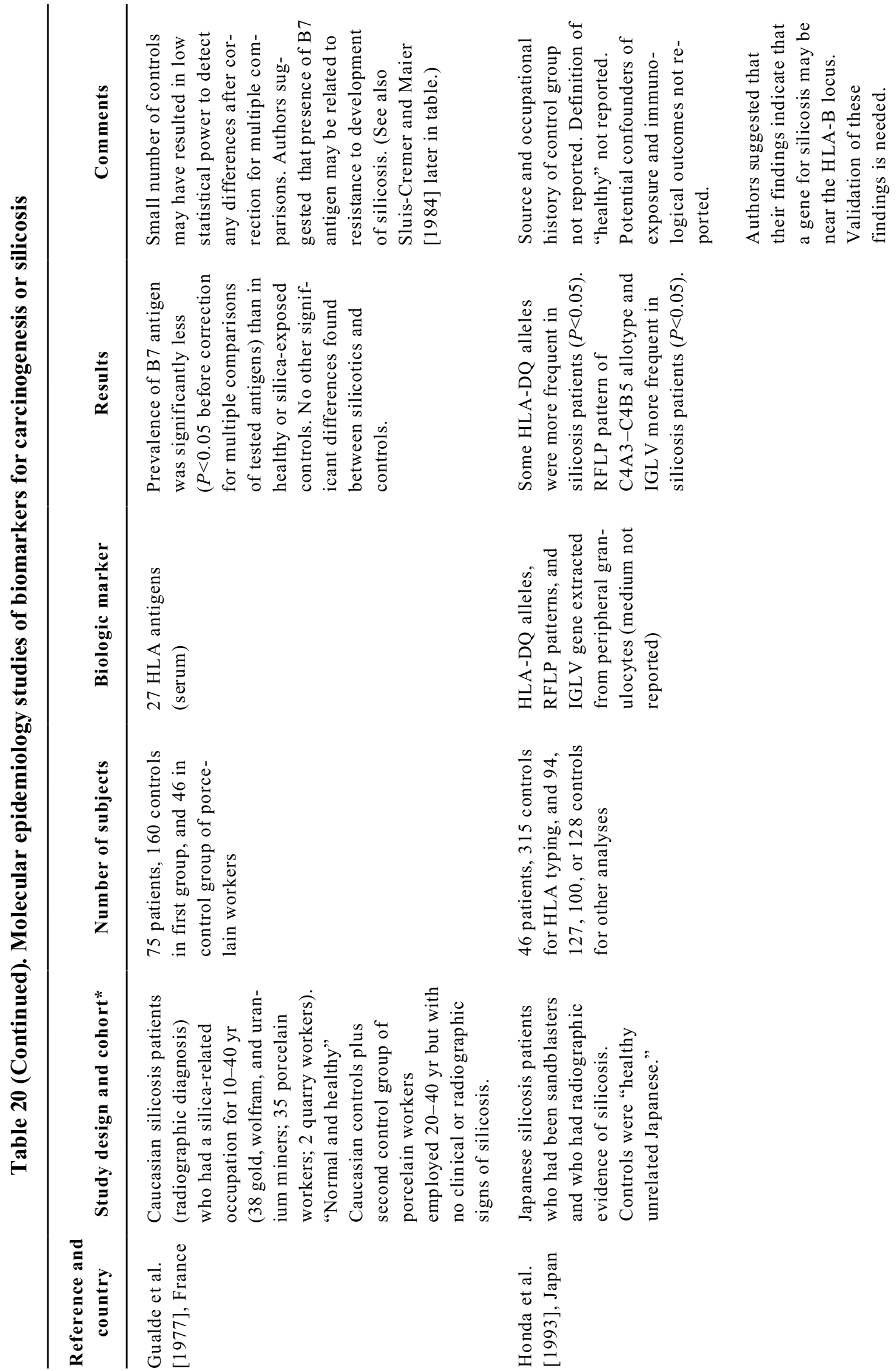




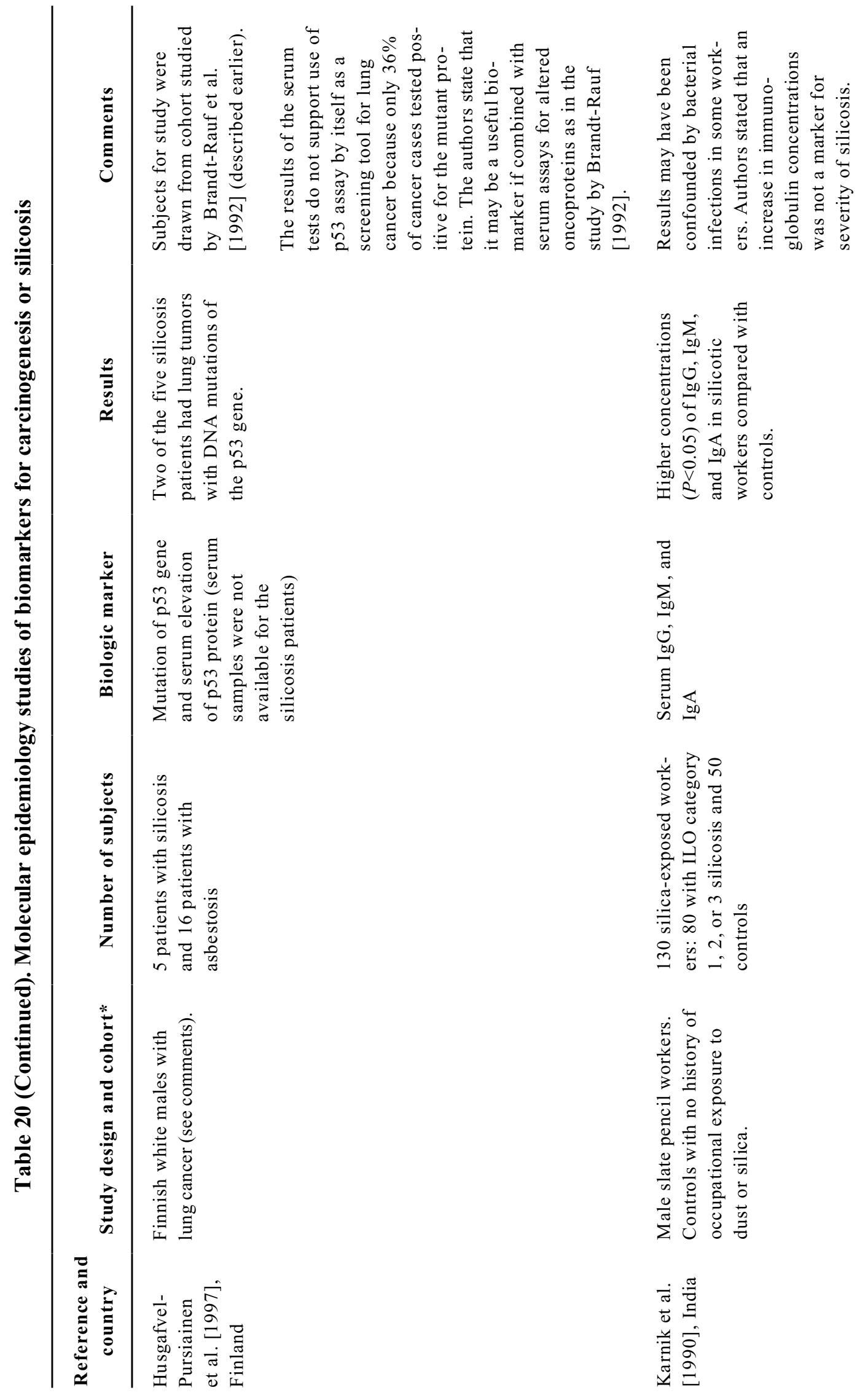




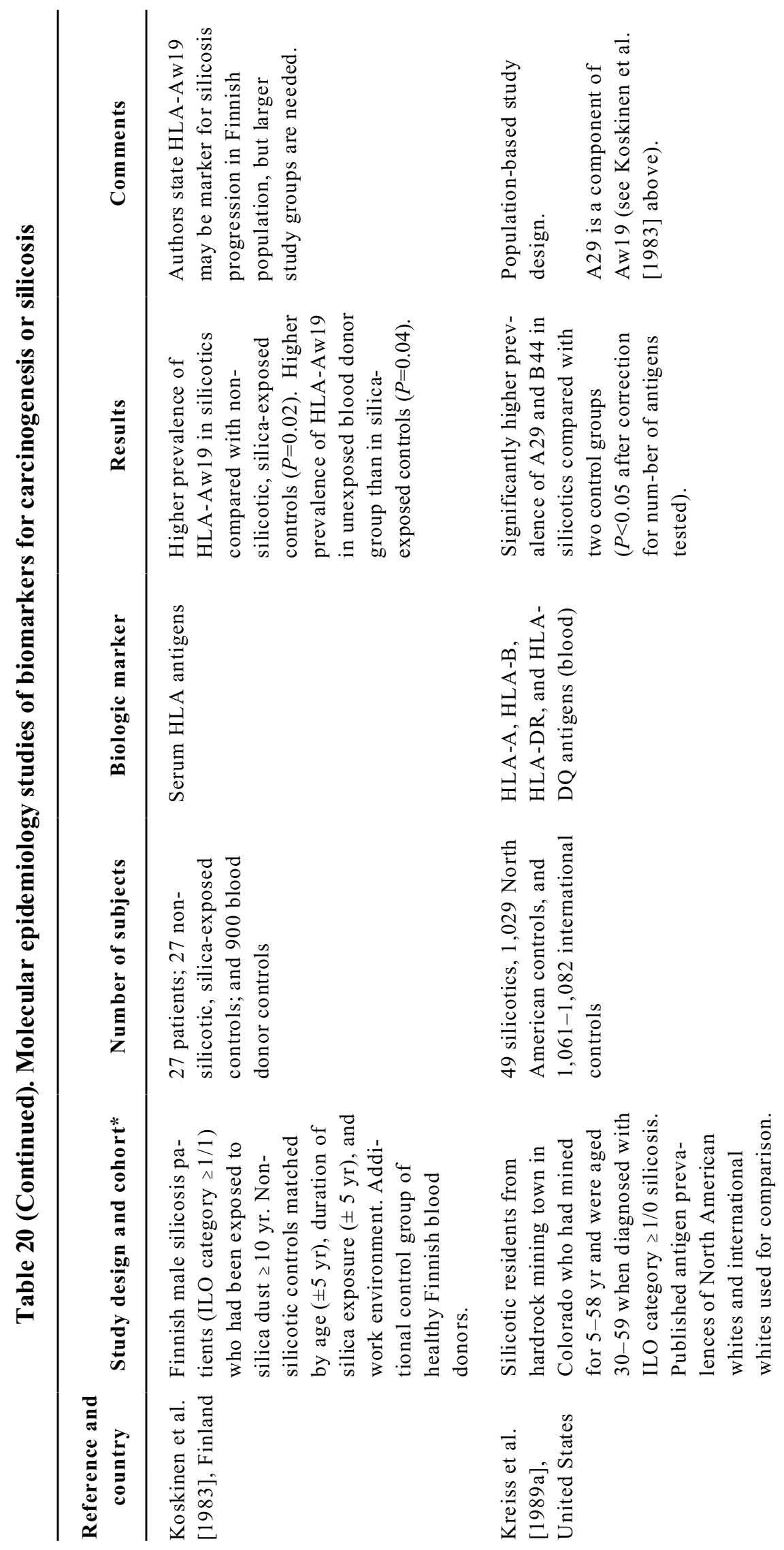

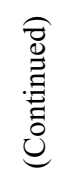

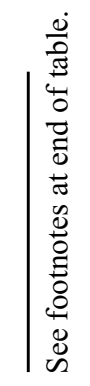




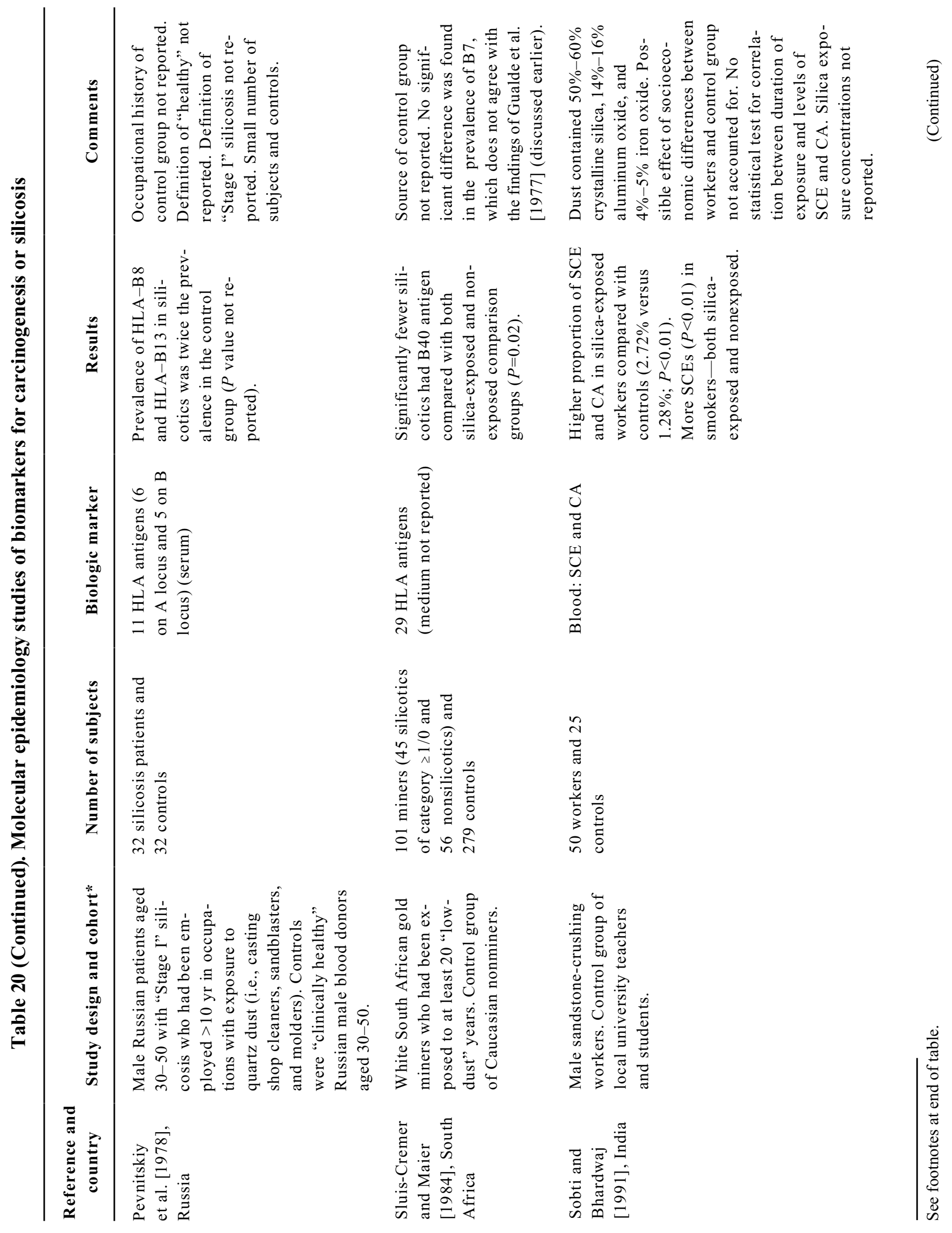




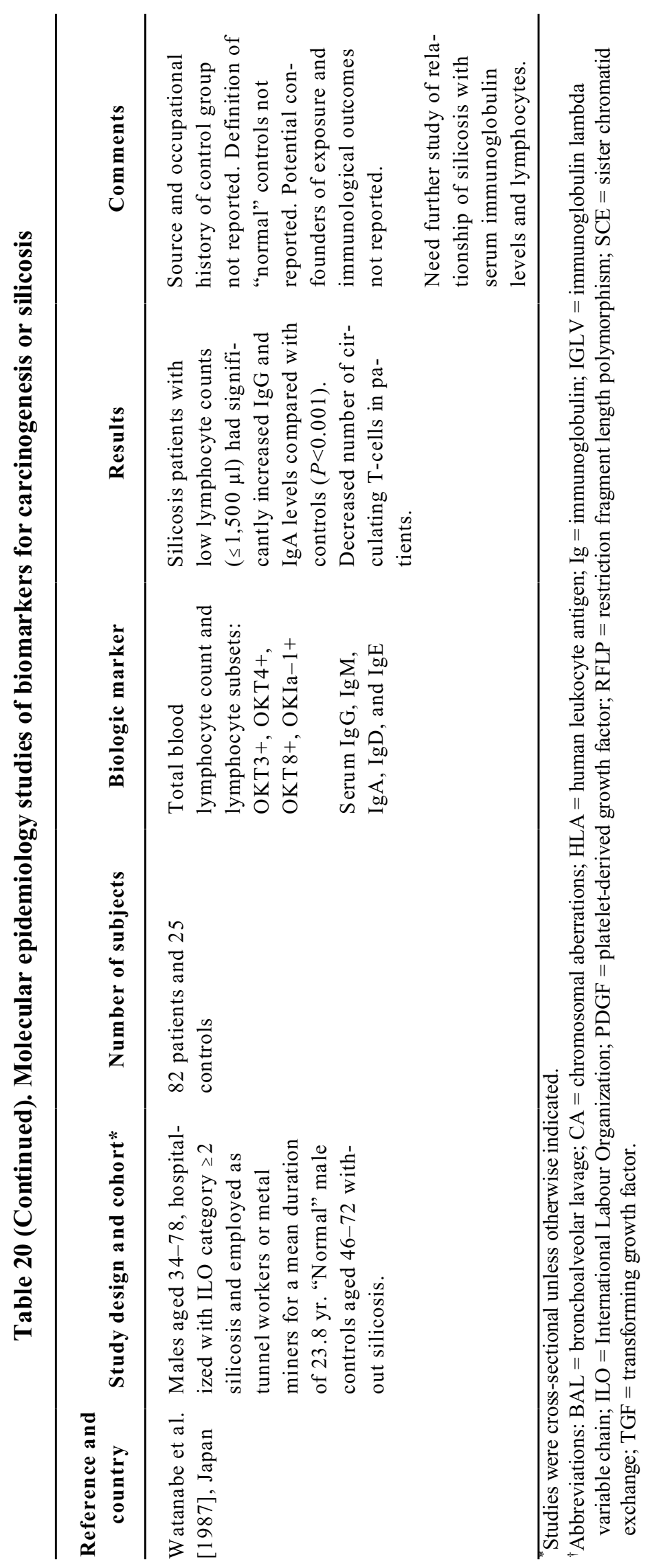




\subsection{Cytotoxicity}

Respirable crystalline silica is known to cause silicosis; however, the molecular mechanism responsible for the cellular injury that precedes the lung disease is unknown. Extensive in vitro and in vivo research has been conducted to evaluate the effects of crystalline silica on mammalian cells. Several mechanisms have been proposed to explain the cause of the cellular damage [Lapp and Castranova 1993]:

1. Direct cytotoxicity of crystalline silica

2. Stimulation of the alveolar macrophages by silica and subsequent release of cytotoxic enzymes or oxidants

3. Stimulation of the alveolar macrophages to release inflammatory factors (e.g., interleukin-8, leukotriene $\mathrm{B}_{4}$, platelet-activating factor, tumor necrosis factor, plateletderived growth factor) that recruit polymorphonuclear leukocytes, which in turn may release cytotoxins

4. Stimulation of the alveolar macrophages to release factors that initiate fibroblast production and collagen synthesis (e.g., interleukin-1, tumor necrosis factor, platelet-derived growth factor, fibronectin, and alveolar macrophage-derived growth factor)

\subsection{Genotoxicity and Related Effects}

Some studies have demonstrated the ability of quartz to induce micronuclei in mammalian cells in culture [Hesterberg et al. 1986; Nagalakshmi et al. 1995; Oshimura et al. 1984] (Table 21). However, other in vitro studies did not observe chromosomal aberration [Nagalakshmi et al. 1995; Oshimura et al. 1984], hprt (hypoxanthine-guanine phosphoribosyl transferase) gene mutation [Driscoll et al. 1997], or aneuploid or tetraploid cells [Price-Jones et al. 1980; Oshimura et al. 1984; Hesterberg et al. 1986]. An in vivo treatment of rats with quartz induced mutation in rat alveolar epithelial cells (Table 21) [Driscoll 1995; 1997].

Pairon et al. [1990] tested tridymite (i.e., Tridymite 118) and quartz (i.e., Min-U-Sil 5) particles for genotoxic effects. Tridymite induced a significant number of sister chromatid exchanges (SCEs) in co-cultures of human lymphocytes and monocytes $(P<0.05$ compared with control cells) at doses of 5 and $50 \mu \mathrm{g} / \mathrm{cm}^{2}$ $(87.9 \%$ of the tridymite particles had a diameter $<1 \mu \mathrm{m})$. However, the number of SCEs in purified human lymphocytes that were treated with the same doses of tridymite particles did not differ significantly from control cells [Pairon et al. 1990]. Results of the same experiments with quartz did not yield a clear conclusion about the ability of quartz to induce a significant number of SCEs (Table 21) [Pairon et al. 1990].

In vitro cellular transformation systems model the in vivo process of carcinogenesis [Gao et al. 1997; Gu and Ong 1996]. The ability of quartz to induce dose-dependent morphological transformation of cells in vitro has been demonstrated in experiments with Syrian hamster embryo cells [Hesterberg and Barrett 1984] and mouse embryo BALB/c-3T3 cells [Saffiotti and Ahmed 1995]. Gu and Ong [1996] also reported a significant increase in the frequency of transformed foci of mouse embryo BALB/c-3T3 cells after treatment with Min-U-Sil-5 quartz. These studies indicate that crystalline silica can morphologically transform mammalian cells. However, further studies are needed to determine whether the transforming activity of silica is related to its carcinogenic potential. 
Table 21. Summary of the genotoxic effects of quartz in mammalian cells

\begin{tabular}{|c|c|c|c|c|}
\hline \multirow[b]{2}{*}{ Genotoxic effect } & \multicolumn{2}{|c|}{ In vitro studies } & \multicolumn{2}{|c|}{ In vivo studies } \\
\hline & $\begin{array}{c}\text { Number of } \\
\text { positive } \\
\text { studies/number of } \\
\text { studies available }\end{array}$ & Reference & $\begin{array}{c}\text { Number of positive } \\
\text { studies/number of } \\
\text { studies available }\end{array}$ & Reference \\
\hline $\begin{array}{l}\text { Sister chromatid } \\
\text { exchange }\end{array}$ & $1 * / 3$ & $\begin{array}{l}\text { Price-Jones et al. [1980] } \\
\text { Pairon et al. [1990] } \\
\quad \text { ( } 2 \text { experiments })\end{array}$ & $1 \% / 1$ & $\begin{array}{l}\text { Sobti and Bhardwaj } \\
\text { [1991] }\end{array}$ \\
\hline $\begin{array}{l}\text { Chromosomal } \\
\text { aberrations }\end{array}$ & $0 / 3$ & $\begin{array}{l}\text { Nagalakshmi et al. [1995] } \\
\quad(2 \text { experiments }) \\
\text { Oshimura et al. [1984] }\end{array}$ & $1^{*} / 1$ & $\begin{array}{l}\text { Sobti and Bhardwaj } \\
\text { [1991] }\end{array}$ \\
\hline Micronuclei & $3 / 4$ & $\begin{array}{l}\text { Oshimura et al. [1984] } \\
\text { Hesterberg et al. [1986] } \\
\text { Nagalakshmi et al. [1995] } \\
\quad(2 \text { experiments })^{\dagger}\end{array}$ & $0 / 1$ & $\begin{array}{l}\text { Vanchugova et al. } \\
\text { [1985] }\end{array}$ \\
\hline $\begin{array}{l}\text { Aneuploidy or } \\
\text { tetraploidy }\end{array}$ & $0 / 3$ & $\begin{array}{l}\text { Price-Jones et al. [1980]; } \\
\text { Oshimura et al. [1984]; } \\
\text { Hesterberg et al. [1986] }\end{array}$ & $0 / 0$ & \\
\hline hprt mutation & $0 / 1$ & Driscoll et al. [1997] & $2 / 2^{\S}$ & $\begin{array}{l}\text { Driscoll et al. } \\
\quad[1995,1997]\end{array}$ \\
\hline
\end{tabular}

Source: IARC [1997].

*One questionably positive study available.

†ne experiment by Nagalakshmi et al. [1995] showed an increase in the frequency of micronucleated cells at all concentrations tested, but the increase was statistically significant $(P<0.05)$ only at the two highest concentrations tested.

${ }^{\ddagger}$ hprt = hypoxanthine-guanine phosphoribosyl transferase.

${ }^{\S}$ Mutagenic response associated with inflammation. 
Researchers at the National Cancer Institute have examined the ability of quartz, cristobalite, and tridymite particles to cause deoxyribonucleic acid (DNA) damage (i.e., strand breakage) [Saffiotti et al. 1993; Shi et al. 1994; Daniel et al. 1993; Daniel 1993, 1995]. Although the results of those studies demonstrated the ability of crystalline silica to cause damage to isolated DNA in acellular systems, reviewers at IARC [1997] recently stated that the relevance of these assays to assess quartz-related genetic effects in vivo was "questionable" because (1) the nonphysiological experimental conditions did not apply to intracellular silica exposure and (2) very high doses of silica were used in the DNA breakage assays [IARC 1997].

Several studies conducted since the IARC review found that crystalline silica induced DNA damage (i.e., DNA migration). Zhong et al. [1997] found that by using the alkaline single cell gel/comet (SCG) assay, crystalline silica (Min-U-Sil 5) induced DNA damage in cultured Chinese hamster lung fibroblasts (V79 cells) and human embryonic lung fibroblasts (Hel 299 cells) [Zhong et al. 1997]. Amorphous silica (Spherisorb), but not carbon black, was also found to induce DNA damage in these mammalian cells. However, the DNAdamaging activity of amorphous silica was not as high as the damaging activity of crystalline silica [Zhong et al. 1997]. Liu et al. [1996, 1998] challenged Chinese hamster lung fibroblasts with dusts pretreated with a phospholipid surfactant to simulate the condition of particles immediately after deposition on the pulmonary alveolar surface. Results of the experiments showed that untreated Min-U-Sil 5, Min-U-Sil 10, and noncrystalline silica induced micronucleus formation in a dose-dependent manner, but surfactant pretreatment suppressed that activity [Liu et al. 1996]. A subsequent experiment found that surfactant pretreatment suppressed quartzinduced DNA damage in lavaged rat pulmonary macrophages, but DNA-damaging activity was restored with time as the phospholipid surfactant was removed by intracellular digestion [Liu et al. 1998].

Shi et al. [1998] recently reviewed published literature on (1) the generation of reactive oxygen species (ROS) directly from silica and from silica-stimulated cells, (2) the role of ROS in silica-induced DNA damage and silica-induced cell proliferation, and (3) other silica-mediated reactions. A proposed mechanism for silica-induced generation of ROS species and carcinogenesis is described by Shi et al. [1998]. Experimental research is continuing to determine whether crystalline silica particles have a direct genotoxic effect that could cause lung tumor formation in humans.

\subsection{Carcinogenicity}

Experimental evidence of the carcinogenicity of quartz particles is based on the results of long-term inhalation and intratracheal instillation studies of rats, which are summarized in Tables 22 and 23 [Saffiotti et al. 1996]. Several issues are apparent from the results of the rat studies [Holland 1995]:

1. The appearance of tumors (usually adenocarcinomas or epidermoid carcinomas) is a late phenomenon.

2. Lung fibrosis is usually present in the rats with tumors.

3. No adequate dose-response data exist because multiple-dose experiments have not been conducted in the rat except for the inhalation study by Spiethoff et al. [1992].

4. Comparability of the intratracheal instillation and inhalation studies is difficult because of notable differences in methods and materials. 
Table 22. Summary of data on lung tumors induced in rats by crystalline silica

\begin{tabular}{|c|c|c|c|c|c|c|}
\hline \multirow[b]{2}{*}{$\begin{array}{c}\text { Sample and exposure } \\
\text { conditions }\end{array}$} & \multirow[b]{2}{*}{$\begin{array}{l}\text { Rat } \\
\text { strain }\end{array}$} & \multirow[b]{2}{*}{ Sex } & \multicolumn{2}{|c|}{$\begin{array}{c}\text { Incidence of lung } \\
\text { tumors }\end{array}$} & \multirow[b]{2}{*}{ Reference } & \multirow[b]{2}{*}{ Comments } \\
\hline & & & $\begin{array}{l}\text { Treated } \\
\text { rats }\end{array}$ & Controls & & \\
\hline $\begin{array}{l}\text { Quartz (Min-U-Sil 5): } \\
\text { Intratracheal } \\
\text { instillation of } \\
7 \mathrm{mg} / \mathrm{wk} \text { for } 10 \mathrm{wk}\end{array}$ & $\begin{array}{l}\text { Sprague- } \\
\text { Dawley }\end{array}$ & $-^{\dagger}$ & $6 / 36$ & $0 / 58$ & $\begin{array}{l}\text { Holland } \\
\text { et al. [1983] }\end{array}$ & $\begin{array}{l}\text { Treated rats had } \\
1 \text { adenoma and } \\
5 \text { carcinomas. }\end{array}$ \\
\hline $\begin{array}{l}\text { Inhalation (nose only) } \\
\text { of } 12 \pm 5 \mathrm{mg} / \mathrm{m}^{3} \text { for } \\
\text { up to } 2 \mathrm{yr}\end{array}$ & $\begin{array}{l}\text { Fischer } \\
344\end{array}$ & $\mathrm{~F}$ & $20 / 60$ & $0 / 54$ & $\begin{array}{l}\text { Holland } \\
\text { et al. [1986] }\end{array}$ & $\begin{array}{l}\text { Treated rats had } \\
6 \text { adenomas, } \\
11 \text { adenocarcinomas, and } \\
3 \text { epidermoid carcinomas. }\end{array}$ \\
\hline $\begin{array}{l}\text { Inhalation of } \\
51.6 \mathrm{mg} / \mathrm{m}^{3} \text { for various } \\
\text { durations; sacrificed at } \\
24 \text { months }\end{array}$ & $\begin{array}{l}\text { Fischer } \\
344\end{array}$ & $\begin{array}{l}\mathrm{F} \\
\mathrm{M}\end{array}$ & $\begin{array}{c}10 / 53 \\
1 / 47\end{array}$ & $\begin{array}{l}0 / 47 \\
0 / 42\end{array}$ & $\begin{array}{l}\text { Dagle et al. } \\
{[1986]}\end{array}$ & $\begin{array}{l}\text { Treated female rats had } \\
10 \text { epidermoid } \\
\text { carcinomas. } \\
\text { Treated male rats had } \\
1 \text { epidermoid carcinoma. }\end{array}$ \\
\hline $\begin{array}{l}\text { Intratracheal instilla- } \\
\text { tion of } 20 \mathrm{mg} \text { in left } \\
\text { lung; sacrificed at } 12 \text {, } \\
18 \text {, or } 22 \text { months, or } \\
\text { found dead }\end{array}$ & $\begin{array}{l}\text { Fischer } \\
344\end{array}$ & M & $30 / 67$ & $1 / 75$ & $\begin{array}{l}\text { Groth et al. } \\
{[1986]}\end{array}$ & $\begin{array}{l}\text { Treated rats had } \\
30 \text { adenocarcinomas. } \\
\text { Controls had } \\
1 \text { adenocarcinoma. }\end{array}$ \\
\hline $\begin{array}{l}\text { Novaculite (i.e., micro- } \\
\text { crystalline quartz): } \\
\text { Intratracheal instilla- } \\
\text { tion of } 20 \mathrm{mg} \text { in left } \\
\text { lung; sacrificed at } 12 \text {, } \\
18, \text { or } 22 \text { months, or } \\
\text { found dead }\end{array}$ & $\begin{array}{l}\text { Fischer } \\
344\end{array}$ & M & $21 / 72$ & $1 / 75$ & $\begin{array}{l}\text { Groth et al. } \\
{[1986]}\end{array}$ & $\begin{array}{l}\text { Treated rats had } \\
20 \text { adenocarcinomas and } \\
1 \text { epidermoid carcinoma. } \\
\text { Controls had } 1 \text { adeno- } \\
\text { carcinoma. }\end{array}$ \\
\hline $\begin{array}{l}\text { Raw shale dust: } \\
\text { Inhalation (nose only) } \\
\text { of } 152 \pm 51 \mathrm{mg} / \mathrm{m}^{3} \\
\text { (average quartz } \\
\text { content: } 8 \%-12 \% \text { ) }\end{array}$ & $\begin{array}{l}\text { Fischer } \\
344\end{array}$ & $\mathrm{~F}$ & $17 / 59$ & $\begin{array}{l}0 / 54 \\
1 / 15^{\ddagger}\end{array}$ & $\begin{array}{l}\text { Holland } \\
\text { et al. [1986] }\end{array}$ & $\begin{array}{l}\text { Treated rats had } \\
2 \text { adenomas, } \\
8 \text { adenocarcinomas, and } \\
7 \text { epidermoid carcinomas. } \\
\text { Controls had } 1 \text { adenoma. }\end{array}$ \\
\hline
\end{tabular}

See footnotes at end of table.

(Continued) 
Table 22 (Continued). Summary of data on lung tumors induced in rats by crystalline silica

\begin{tabular}{|c|c|c|c|c|c|c|}
\hline \multirow[b]{2}{*}{$\begin{array}{c}\text { Sample and exposure } \\
\text { conditions }\end{array}$} & \multirow[b]{2}{*}{$\begin{array}{l}\text { Rat } \\
\text { strain }\end{array}$} & \multirow[b]{2}{*}{$\operatorname{Sex}$} & \multicolumn{2}{|c|}{$\begin{array}{l}\text { Incidence of lung } \\
\text { tumors }\end{array}$} & \multirow[b]{2}{*}{ Reference } & \multirow[b]{2}{*}{ Comments } \\
\hline & & & $\begin{array}{l}\text { Treated } \\
\text { rats }\end{array}$ & Controls & & \\
\hline $\begin{array}{l}\text { Spent shale dust: } \\
\text { Inhalation (nose only) } \\
\text { of } 176 \pm 75 \mathrm{mg} / \mathrm{m}^{3} \\
\text { (average quartz } \\
\text { content: } 8 \%-12 \% \text { ) }\end{array}$ & $\begin{array}{l}\text { Fischer } \\
344\end{array}$ & $\mathrm{~F}$ & $11 / 59$ & $\begin{array}{l}0 / 54 \\
1 / 15^{*}\end{array}$ & $\begin{array}{l}\text { Holland } \\
\text { et al. [1986] }\end{array}$ & $\begin{array}{l}\text { Treated rats had } \\
2 \text { adenomas, } \\
8 \text { adenocarcinomas, and } \\
1 \text { epidermoid carcinoma. } \\
\text { Controls had } 1 \text { adenoma. }\end{array}$ \\
\hline $\begin{array}{l}\text { Quartz (DQ12): } \\
\text { Inhalation of } 1 \mathrm{mg} / \mathrm{m}^{3} \\
\text { for } 24 \text { months }\end{array}$ & $\begin{array}{l}\text { Fischer } \\
344 \\
\text { Fischer } \\
344\end{array}$ & M & $12 / 50$ & $\begin{array}{l}3 / 100 \\
\text { (male and } \\
\text { female) } \\
-\end{array}$ & $\begin{array}{l}\text { Muhle et al. } \\
{[1989]}\end{array}$ & $\begin{array}{l}\text { Treated female rats had } \\
2 \text { keratinizing cystic } \\
\text { squamous cell tumors, } \\
2 \text { adenomas, and } \\
8 \text { adenocarcinomas. } \\
\text { Treated male rats had } \\
2 \text { keratinizing cystic } \\
\text { squamous cell tumors, } \\
2 \text { adenocarcinomas, } \\
1 \text { adenosquamous carcin- } \\
\text { oma, and } 1 \text { squamous cell } \\
\text { carcinoma. } \\
\text { Controls had } 2 \text { adenomas } \\
\text { and } 1 \text { adenocarcinoma. }\end{array}$ \\
\hline $\begin{array}{l}\text { Inhalation (nose only) } \\
\text { of } 6 \mathrm{mg} / \mathrm{m}^{3} \text { for } 29 \text { days } \\
\text { followed by lifetime } \\
\text { observation }\end{array}$ & Wistar & $\mathrm{F}$ & $62 / 82$ & $0 / 85$ & $\begin{array}{l}\text { Spiethoff } \\
\text { et al. [1992] }\end{array}$ & $\begin{array}{l}\text { Treated rats had } \\
8 \text { adenomas, } \\
17 \text { bronchioloalveolar } \\
\text { carcinomas, and } \\
37 \text { squamous cell } \\
\text { carcinomas. }\end{array}$ \\
\hline $\begin{array}{l}\text { Inhalation (nose only) } \\
\text { of } 30 \mathrm{mg} / \mathrm{m}^{3} \text { for } \\
29 \text { days followed by } \\
\text { lifetime observation }\end{array}$ & Wistar & $\mathrm{F}$ & $69 / 82$ & $0 / 85$ & $\begin{array}{l}\text { Spiethoff } \\
\text { et al. [1992] }\end{array}$ & $\begin{array}{l}\text { Treated rats had } \\
13 \text { adenomas, } \\
26 \text { bronchioloalveolar } \\
\text { carcinomas, and } \\
30 \text { squamous cell } \\
\text { carcinomas. }\end{array}$ \\
\hline
\end{tabular}

Source: Adapted from Saffiotti et al. [1996].

"Number of lung tumors per number of rats observed.

'Not reported.

Investigators used two control groups. 
Table 23. Lung tumors induced in Fischer 344 rats by a single intratracheal instillation of quartz

\begin{tabular}{|c|c|c|c|c|c|c|}
\hline \multirow{2}{*}{$\begin{array}{c}\text { Treatment } \\
\text { sample and dose }\end{array}$} & \multirow[b]{2}{*}{ Sex } & \multirow[b]{2}{*}{ Observation time } & \multicolumn{2}{|c|}{$\begin{array}{l}\text { Incidence of } \\
\text { lung tumors }\end{array}$} & \multirow{2}{*}{$\begin{array}{c}\text { Total } \\
\text { number of } \\
\text { lung tumors }\end{array}$} & \multirow[b]{2}{*}{ Histological types } \\
\hline & & & Number ${ }^{\dagger}$ & $\%$ & & \\
\hline \multicolumn{7}{|l|}{ Untreated: } \\
\hline No dose & M & Died after 17 months & $0 / 32$ & - & 0 & - \\
\hline No dose & $\mathrm{F}$ & Died after 17 months & $1 / 20$ & 5 & 1 & 1 adenoma \\
\hline \multicolumn{7}{|l|}{$\begin{array}{l}\text { Quartz } \\
\text { (Min-U-Sil 5): }\end{array}$} \\
\hline $12-\mathrm{mg}$ dose & M & $\begin{array}{l}\text { Sacrificed at } 11 \text { months } \\
\text { Sacrificed at } 17 \text { months } \\
\text { Died after } 17 \text { months }\end{array}$ & $\begin{array}{r}3 / 18 \\
6 / 19 \\
12 / 14\end{array}$ & $\begin{array}{l}17 \\
32 \\
86\end{array}$ & 37 & $\begin{array}{l}6 \text { adenomas, } 25 \text { adeno- } \\
\text { carcinomas, } 1 \text { undifferen- } \\
\text { tiated carcinoma, } 2 \text { mixed } \\
\text { carcinomas, and } 3 \text { epi- } \\
\text { dermoid carcinomas }\end{array}$ \\
\hline 12-mg dose & $\mathrm{F}$ & $\begin{array}{l}\text { Sacrificed at } 11 \text { months } \\
\text { Sacrificed at } 17 \text { months } \\
\text { Died after } 17 \text { months }\end{array}$ & $\begin{array}{r}8 / 19 \\
10 / 17 \\
8 / 9\end{array}$ & $\begin{array}{l}42 \\
59 \\
89\end{array}$ & 59 & $\begin{array}{l}2 \text { adenomas, } 46 \text { adeno- } \\
\text { carcinomas, } 3 \text { undifferen- } \\
\text { tiated carcinomas, } 5 \text { mixed } \\
\text { carcinomas, and } 3 \text { epi- } \\
\text { dermoid carcinomas }\end{array}$ \\
\hline 20-mg dose & $\mathrm{F}$ & Died after 17 months & $6 / 8$ & 75 & 13 & $\begin{array}{l}1 \text { adenoma, } 10 \text { adeno- } \\
\text { carcinomas, } 1 \text { mixed } \\
\text { carcinoma, and } 1 \text { epi- } \\
\text { dermoid carcinoma }\end{array}$ \\
\hline \multicolumn{7}{|l|}{$\begin{array}{l}\text { Quartz (hydrogen } \\
\text { fluoride-etched } \\
\text { Min-U-Sil 5): }\end{array}$} \\
\hline 12-mg dose & M & $\begin{array}{l}\text { Sacrificed at } 11 \text { months } \\
\text { Sacrificed at } 17 \text { months } \\
\text { Died after } 17 \text { months }\end{array}$ & $\begin{array}{r}2 / 18 \\
7 / 19 \\
7 / 9\end{array}$ & $\begin{array}{l}11 \\
37 \\
78\end{array}$ & 20 & $\begin{array}{l}5 \text { adenomas, } 14 \text { adeno- } \\
\text { carcinomas, and } 1 \text { mixed } \\
\text { carcinoma }\end{array}$ \\
\hline 12-mg dose & $\mathrm{F}$ & $\begin{array}{l}\text { Sacrificed at } 11 \text { months } \\
\text { Sacrificed at } 17 \text { months } \\
\text { Died after } 17 \text { months }\end{array}$ & $\begin{array}{r}7 / 18 \\
13 / 16 \\
8 / 8\end{array}$ & $\begin{array}{r}39 \\
81 \\
100\end{array}$ & 45 & $\begin{array}{l}1 \text { adenoma, } 36 \text { adeno- } \\
\text { carcinomas, } 3 \text { mixed } \\
\text { carcinomas, and } 5 \text { epi- } \\
\text { dermoid carcinomas }\end{array}$ \\
\hline
\end{tabular}

Sources: Saffiotti et al. [1993; 1996].

*As mg quartz suspended in $0.3 \mathrm{ml}$ saline.

'Number of rats with lung tumors per number of rats observed.

${ }^{\star}$ At all observation times. 
Although new long-term carcinogenesis studies in animals may provide information about dose-response relationships and inhibition of quartz toxicity or reactivity in vivo, in vitro studies are needed to develop effective cellular and molecular models of carcinogenesis [Holland 1995; Saffiotti et al. 1996]. 


\section{Conclusions}

The following conclusions about the health effects caused by exposure to respirable crystalline silica are derived from studies in humans and animals published since the 1974 criteria document [NIOSH 1974]. These studies support the risk of silicosis, lung cancer, and several other debilitating and fatal diseases from occupational exposure to crystalline silica. The onset of silicosis and lung cancer is thought to be related to the biological activity and the lack of solubility of crystalline silica particles in body fluids and tissues.

\subsection{Lung Cancer}

In 1988 testimony to the U.S. Department of Labor, NIOSH recommended that respirable crystalline silica be considered a potential occupational carcinogen [54 Fed. Reg. 2521 (1989)]. Since then, additional studies have supported a lung cancer risk from exposure to crystalline silica:

- Lung cancer is associated with occupational exposures to crystalline silica [ATS 1997], specifically quartz and cristobalite [IARC 1997].

- An exposure-response relationship has been reported in studies of miners, diatomaceous earth workers, granite workers, pottery workers, refractory brick workers, and other workers (see Section 3.4.2).

- Meta-analyses of the epidemiologic studies of silica exposure and lung cancer reported a moderate summary relative risk of 1.3 for silica-exposed workers [Steenland and Stayner 1997] and higher summary relative risks of 2.2 to 2.8 for silicotic workers [Steenland and Stayner 1997; Tsuda et al. 1997; Smith et al. 1995]. Some of the studies of silica-exposed workers controlled for the effects of smoking and others did not. The available data also support the conclusion that silicosis produces an increased risk for bronchogenic carcinoma, but the data are "less clear" as to whether silica exposure is associated with lung cancer in the absence of silicosis [ATS 1997].

\subsection{Noncarcinogenic Health Effects}

In 1974, NIOSH established an REL for respirable crystalline silica of $0.05 \mathrm{mg} / \mathrm{m}^{3}$ as a 10-hr TWA to prevent the risk of silicosis from occupational exposure [NIOSH 1974]. Since then, additional studies have indicated that a risk for silicosis exists at the NIOSH REL. Three recent epidemiologic studies have shown that the estimated risk of silicosis for a 45 -year working lifetime is $47 \%$ to $90 \%$ for cumulative silica exposures at concentrations equal to the current OSHA and MSHA PELs, and approximately $10 \%$ to $30 \%$ at concentrations equal to the NIOSH REL (see appendix) [Kreiss and Zhen 1996; Steenland and Brown 1995a; Hnizdo and Sluis-Cremer 1993]. The results from these studies support the need for continued medical and epidemiologic surveillance of workers after they leave employment and for revision of OSHA and MSHA standards for respirable crystalline silica. 
Additional studies have reported the risk for several other debilitating and fatal diseases:

- Several epidemiologic studies have reported statistically significant numbers of excess deaths or cases of immunologic disorders and autoimmune diseases in silica-exposed workers. These diseases and disorders include scleroderma [Steenland and Brown 1995b; Cowie 1987], rheumatoid arthritis [Sluis-Cremer et al. 1986; Klockars et al. 1987; Rosenman and Zhu 1995], systemic lupus erythematosus [Steenland and Brown 1995b], and sarcoidosis [Rafnsson et al. 1998].

- Recent epidemiologic studies have reported statistically significant associations of occupational exposure to crystalline silica with renal diseases and subclinical renal changes [Steenland et al. 1990, 1992; Steenland and Brown 1995b; Calvert et al. 1997; Nuyts et al. 1995; Hotz et al. 1995; Boujemaa et al. 1994; $\mathrm{Ng}$ et al. 1993].

- Crystalline silica may affect the immune system, leading to mycobacterial infections (tuberculous and nontuberculous) or fungal infections [ATS 1997; NIOSH 1992a,b, 1996b; Ziskind et al. 1976; Parkes 1982; Parker 1994], especially in workers with silicosis [Corbett et al. 1999; Kleinschmidt and Churchyard 1997; Althouse et al. 1995; Goldsmith et al. 1995; Hnizdo and Murray 1998; ATS 1997].

- Occupational exposure to respirable crystalline silica is associated with bronchitis, COPD, and emphysema (see Section 3.5). Some epidemiologic studies suggest that these health effects may be less frequent or absent in nonsmokers.

\subsection{Exposures, Monitoring, and Controls}

Published studies on workers exposed to crystalline silica indicate that exposures still occur at concentrations exceeding the OSHA and MSHA PELs and the NIOSH REL. Engineering control methods used to control silica exposures in some industrial environments may not be feasible for reducing airborne exposures in other workplaces where their implementation is hindered by the type of work being performed. In addition, sampling and analytical techniques used to measure airborne crystalline silica exposures are limited in their ability to accurately quantify exposures below the NIOSH REL. The following issues must be resolved to prevent silicosis and other debilitating and fatal diseases:

- Many occupational exposures to crystalline silica still exceed applicable Federal standards. Of the 255 industries targeted for OSHA inspection between 1980 and $1992,48 \%$ had overall average exposures for respirable quartz that exceeded the PEL [Freeman and Grossman 1995]. Analysis of OSHA compliance data for five of the three-digit SICs (masonry and plastering, heavy construction, painting and paper hanging, iron and steel foundries, and metal services) for the period 1979-1995 indicated that an estimated number of workers were exposed to concentrations of respirable crystalline silica that were at least 10 times the NIOSH REL of $0.05 \mathrm{mg} / \mathrm{m}^{3}$ (10-hr TWA) [Linch et al. 1998] (see Section 2.3).

- Workers are exposed to crystalline silica in a variety of industries and occupations in which engineering controls may not be feasible for reducing exposures and may necessitate the use of other worker protection measures such as substitution 
(use of a less hazardous material) or respirator use.

- Current sampling and analytical methods used to evaluate occupational exposure to crystalline silica do not meet the appropriate accuracy criterion needed to quantify exposures at concentrations below the NIOSH REL of $0.05 \mathrm{mg} / \mathrm{m}^{3}$ (see Section 2.4). However, the recent introduction of a new sampler that can operate at a higher flow rate and the ongoing improvements in the analysis of crystalline silica should soon make it possible to measure crystalline silica exposure accurately when it is below $0.05 \mathrm{mg} / \mathrm{m}^{3}$.
Until these improved sampling and analytical methods are developed for respirable crystalline silica, NIOSH will continue to recommend an exposure limit of $0.05 \mathrm{mg} / \mathrm{m}^{3}$ to reduce the risk of developing silicosis, lung cancer, and other adverse health effects. NIOSH also recommends minimizing the risk of illness that remains for workers exposed at the REL by substituting less hazardous materials for crystalline silica when feasible, by using appropriate respiratory protection when source controls cannot keep exposures below the NIOSH REL, and by making medical examinations available to exposed workers. 


\section{Research Needs}

\subsection{Health-Related Research}

The relationship of occupational crystalline silica exposure with silicosis and other silicarelated diseases is well documented in the literature. However, the mechanisms and particle characteristics that cause silicosis and other silica-related diseases have not been precisely defined. Prevention of silicosis, lung cancer, and other silica-related diseases can be facilitated by the following:

- Development of methods for earlier detection or more definitive noninvasive evaluation of silica-related pulmonary disease, such as methods to improve the sensitivity of radiography for detecting silicosis (these methods were reviewed by Wilt et al. [1998] and Talini et al. [1995])

- Further in vitro and in vivo studies of mechanisms for development of

— silicotic nodules [Craighead 1996]

— autoimmune diseases

- DNA damage by silica particles [Saffiotti et al. 1994]

- Further in vitro and in vivo studies of the toxicity and pathogenicity of

- alpha quartz compared with its polymorphs [Craighead 1996]
- crystalline silica compared with crystalline glass, amorphous silicone, and silicates [Craighead 1996]

- crystalline silica compared with substitute materials for abrasive blasting and other tasks that use crystalline silica

- dust mixtures that contain crystalline silica [Craighead 1996; Donaldson and Borm 1998; Dufresne et al. 1998]

- quartz contaminated with trace elements [Castranova et al. 1997]

- The association of surface properties of silica particles with specific work processes and health effects

- Cellular, molecular, and animal models of silica carcinogenesis to explore whether silica dust is an initiator or a promoter of lung cancer [Craighead 1996] and to evaluate a dose-response relationship

- Animal models of individual susceptibility and the development of fibrosis [Craighead 1996], including the translocation of silica particles from the lungs [Adamson and Prieditis 1998]

- Animal models of the adverse effects of crystalline silica on the kidneys and liver 
- Routes and kinetics of lymphatic transport and deposition of silica particles [Craighead 1996]

Further epidemiologic studies and surveillance of silica-exposed workers are needed to do the following:

- Determine the exposure-response relationship between occupational silica dust exposure and lung cancer in nonsmokers

- Determine why lung cancer risks appear to be higher in silicotic workers (e.g., determine the histologic type and anatomic location of lung cancers in workers with and without silicosis [Ducatman et al. 1997])

- Evaluate exposure-response relationships between occupational silica dust exposure and (1) TB [ATS 1997] and (2) changes in cellular components (lymphocytes, Clara cell protein) or immunoglobulin concentrations

- Determine the relationship between occupational exposure to silica dust and

- TB in silica-exposed workers without diagnosed silicosis

—clinically significant changes in the lung function of nonsmokers

—emphysema in nonsmokers

- gastric cancer and other nonpulmonary cancers

- Gather uniform national and international prevalence and incidence data about silicosis cases to identify industries, occupations, and work areas where preventive measures could be implemented [CSTE 1996; Wagner 1997]
- Gather prevalence, incidence, and mortality data about silica-related diseases such as cancer, scleroderma and other autoimmune diseases, nonmalignant renal disease, and other adverse health effects to assess morbidity and mortality risk factors and to identify areas where preventive measures could be implemented

- Determine whether silicosis or silicarelated lung cancers are related to a specific gene, gene pattern, or other individual susceptibility factors

- Improve the methods for estimating historical exposures for retrospective cohort studies

- Improve the assessment of potential confounding and synergistic effects of smoking in silica-exposed workers [Checkoway 1995]

- Improve the assessment of potential confounding and synergistic effects of other carcinogens present in the work environment of silica-exposed workers [Dufresne et al. 1998]

- Determine whether adverse health effects are associated with occupational exposure to materials that could be substitutes for crystalline silica [NIOSH 1992a]

\subsection{Research Related to Exposure Measurement}

Reducing the OSHA and MSHA PELs for crystalline silica to concentrations below the NIOSH REL $\left(0.05 \mathrm{mg} / \mathrm{m}^{3}\right.$ for up to a $10-\mathrm{hr}$ workday during a 40-hr workweek) would require new methods that can accurately measure low airborne concentrations at the NIOSH accuracy criterion. (Limitations of 
current NIOSH methods for measuring worker exposure to airborne crystalline silica are discussed in Chapter 2). Such new methods will depend on the following types of research and development:

- Reevaluation of the 10-mm nylon cyclone, the GK2.69 cyclone, or other proposed devices at exposure concentrations below $0.05 \mathrm{mg} / \mathrm{m}^{3}$

- Ascertainment of the sampling efficiency of proposed samplers versus particle aerodynamic diameter

- Side-by-side comparison of proposed samplers under field conditions

- Development of samplers that can operate at higher flow rates than those currently available

- Development of working standards that use different types of filter media (e.g., $\mathrm{PVC}$ ) to reduce errors in calibration

- Further improvement of the system used to produce replicate crystalline silica samples for the PAT Program* to

- improve the reproducibility of interlaboratory results for silica analysis,

- eliminate problems with sample overloading, and

- determine how to account for bias between results from different analytical methods

\footnotetext{
${ }^{*}$ This system has undergone improvements from its original form to reduce the intersample variability. Currently, intersample $\mathrm{CV}$ is on the order of 0.08 to 0.12 . Only cursory testing of these improvements has been carried out, and further improvements may be necessary.
}

- Further research to validate the feasibility of "on-filter" analysis under field conditions (preliminary investigation of particle transition between the cyclone and the sample collection cassette indicates that it is possible to improve the uniformity of particles deposited on the filter to permit an accurate on-filter analysis)

- Collaborative testing of any improved or new sampling and analytical methods to demonstrate equivalence

\subsection{Research Related to the Control of Exposure}

Protecting workers from crystalline silica exposures can be accomplished through a number of means. Respiratory protection and administrative controls are important means of protecting workers, but they should not be used as the primary method of preventing worker exposure. Other exposure control methods (including process modifications to eliminate hazards, substitution, and engineering controls) should be the primary focus of any safety and health program in preventing occupational exposures. For some industries, research is needed to develop cost-effective controls; whereas in other industries, work is needed to increase the availability and use of control measures and to explore barriers that prevent the introduction of control technology. Specific types of research are needed in the following industries:

- Construction. The construction industry presents a major challenge for protecting workers. In this industry, crystalline silica is present in many of the building materials and construction substrates (i.e., rock and soil). Silica sand is a major component of concrete and mortar and is used in the production of brick 
and concrete masonry units. In addition to the ubiquitous presence of silica in construction, this industry also faces a challenge from the ever-changing nature of the worksite. These changes create two problems in the control of silica exposures. First, permanent control measures are not feasible for many worksites because of the short duration of the task (e.g., concrete cutting or coring operations). Second, the manner in which the work is performed at a worksite can create a silica exposure for workers at adjacent worksites. Control methods such as wet cutting of bricks and concrete masonry units and use of high-velocity/ low-volume (HVLV) ventilation systems during cutting and grinding of concrete have been effective in reducing exposures to silica at some worksites. However, the following research is needed to improve these techniques and the feasibility of their use:

- The use of water is not a feasible control method for reducing exposures on many interior jobs or in cold temperatures. Research is needed to find methods for increasing (1) the applicability of water to more operations and (2) the use of water in applications where it is considered feasible.

- The use of HVLV ventilation involves problems such as insufficient hood capture velocity, obstruction of the work area by the control, and poor dust collector performance. Research is needed to improve the performance of HVLV systems and the feasibility of their use in other operations.

- Alternative materials and work methods can be used to reduce crystalline silica exposures. For example, concrete forms can be used to impart smoother surface finishes and reduce the need for additional grinding or rework. Additional research is needed to investigate alternative methods for blowing and sweeping on construction sites (e.g., the use of vacuums instead of compressed-air lances to remove debris from cracks in road construction).

- Foundries. Foundries use large volumes of sand in the molds and the cores to produce castings. In general, foundries that cast higher-temperature metals (steel, gray iron, and stainless steel) have the potential for creating higher silica exposures than foundries that cast lowertemperature metals (aluminum, brass, and bronze). The molding sand used in most foundries contains a small percentage of water and other binders. High temperatures dry the sand, making it more likely to become airborne. Various types of controls are being used in foundries, but additional research is needed:

- Alternative processes such as the lost foam casting process have been used for some metal castings, but they require additional investigation to determine whether they can effectively reduce exposures by minimizing the amount of casting cleaning and sand handling required to produce highquality castings.

- Industrial ventilation is widely used to capture and contain silica-containing aerosols. However, its effectiveness is only as good as its design, installation, and maintenance. Research is needed on methods for effectively communicating the need for routine 
and proper maintenance of ventilation systems.

- Automated processes in foundries need to be explored so that workers can be removed from operations that generate high silica exposures.

- The use of HVLV ventilation systems during casting cleaning needs to be evaluated.

- Alternative methods should be investigated for blowing and sweeping in foundries. Vacuums may be feasible as an alternative to compressedair lances and dry sweeping.

- Abrasive blasting operations. Abrasive blasting operations have been documented to generate some of the highest crystalline silica exposures. Other blasting materials such as steel shot, steel grit, and boiler slag have been used as substitutes for silica sand. However, additional research is needed to determine the safety of substitute blasting materials. In addition, replacing silica sand with a substitute blasting material will not eliminate silica exposures when blasting on silica substrates such as concrete or granite. Many of these operations may be modifiable to reduce the amount of blasting required. Additional research is needed on alternative blasting methods such as high-pressure water jetting, slurry blasting, and vacuum blasting. All of these may reduce exposures associated with silica-containing substrates.

- Surface and other mining. Technology exists in the surface mining industry to control exposure to crystalline silica. However, silicosis persists because controls are often not implemented or properly maintained [NIOSH 1996b]. Effective methods are needed for informing drillers and drill owners about the need for continued maintenance and proper use of dust controls on drills. Mine workers at other than surface sites have silica exposures that have not been well characterized. For example, little or no information is available about dust control measures for hard-rock tunneling operations. Research is needed to determine which control measures provide the best protection and are feasible to implement.

- Paints, coatings, glass, cosmetics, plastics, and cleaning products. Crystalline silica is used in a diverse number of products, including paints, coatings, glass, cosmetics, plastics, and cleaning products. However, the hazards associated with silica exposure are often not recognized in these industries. Research is needed to develop methods for communicating hazards and controls to workers and employers. The need is for innovative technologies that can be transferred across industries. Additional research is needed to investigate the feasibility of using HVLV ventilation systems and water to reduce exposures in these industries. 


\section{References}

Abraham JL, McEuen DD [1986]. Inorganic particulates associated with pulmonary alveolar proteinosis: SEM and X-ray microanalysis results. Appl Pathol 4:138146.

Abraham JL, Wiesenfeld SL [1997]. Two cases of fatal PMF in an ongoing epidemic of accelerated silicosis in oilfield sandblasters: Lung pathology and mineralogy. Ann Occup Hyg 41(Suppl 1):440-447.

ACGIH [2001]. 2001 TLVs and BEIs: Threshold limit values for chemical substances and physical agents and biological exposure indices. Cincinnati, OH: American Conference of Governmental Industrial Hygienists.

Adamson IYR, Prieditis H [1998]. Silica deposition in the lung during epithelial injury potentiates fibrosis and increases particle translocation to lymph nodes. Exp Lung Res 24(3):293-306.

Agarwal R, Vasan RS, Singh RR, Saxena SP, Bhadoria DP, Srivastava AK, Verma A, Tiwari SC, Malaviya AN [1987]. Trigeminal and peripheral neuropathy in a patient with systemic sclerosis and silicosis. Clin Exp Rheumatol 5(4):375-376.

Agius RM, Love RG, Davies LST, Hutchison PA, Cherrie JW, Robertson A, Cowie HA, Hurley JF, Seaton A, Soutar CA [1992]. Epidemiological studies of respiratory health and dust exposure in hard rock quarry workers and ex-workers. Edinburgh, Scotland: Institute of Occupational Medicine, Report No. TM/92/10; HSE Contract No. 1/LMD/126/146/88.

Al-Kassimi FA, Hawass NED, Mahmoud K, Al-Majed SAA, Al-Hajjaj MS [1991]. Silicosis of the lung in Saudi Arabia - role of traditional occupations and environmental factors. Saudi Med J 12(5):384-388.

Allison AC, Hart PD [1968]. Potentiation by silica of the growth of Mycobacterium tuberculosis in macrophage cultures. Br J Exp Pathol 49:465-476.

Althouse RB [1998]. E-mail messages on September 22 and 23, 1998 from R Althouse to Faye L. Rice.
Althouse RB, Bang KM, Castellan RM [1995]. Tuberculosis comortality with silicosis-United States, 1979-1991. Appl Occup Environ Hyg 10(12):10371041.

Altieri A, Sperduto B, Verdel U, Porceli D [1984]. Identification of cristobalite and quartz in the production of silicon carbide. Riv Infort Mal Prof 71(1-2):131-135.

Amandus HE, Shy C, Wing S, Blair A, Heineman EF [1991]. Silicosis and lung cancer in North Carolina dusty trades workers. Am J Ind Med 20:57-70.

Amandus HE, Castellan RM, Shy C, Heineman EF, Blair A [1992]. Reevaluation of silicosis and lung cancer in North Carolina dusty trades workers. Am J Ind Med 22:147-153.

Amandus HE, Shy C, Castellan RM, Blair A, Neineman EF [1995]. Silicosis and lung cancer among workers in North Carolina dusty trades. Scand J Work Environ Health 21(Suppl 2):81-83.

Ambrus JL, Sridhar NR [1997]. Immunologic aspects of renal disease. J Am Med Assoc 278(22):1938-1945.

Ampian SG, Virta RL [1992]. Crystalline silica overview: Occurrence and analysis. Washington, DC: U.S. Department of the Interior, Bureau of Mines, Information Circular IC 9317.

Anandan S, Othman M, Cheong I, Chin GL [1995]. Scleroderma secondary to silica exposure - a case report. Singapore Med J 36:559-561.

Anthonisen NR, Wright EC, Hodgkin JE, Hopewell PC, Levin DC, Stevens PM [1986]. Prognosis in chronic obstructive pulmonary disease. Am Rev Respir Dis 133: $14-20$.

Aoki A, Sirai A, Sakamoto H, Igarashi T, Matsunaga K, Ishigatsubo Y, Tani K, Okubo T [1988]. A case of silicosis associated with polymyositis and benign monoclonal gammopathy. Ryumachi 28(5):373-378. 
Archer C, Gordon DA [1996]. Silica and progressive systemic sclerosis (scleroderma): Evidence for workers' compensation policy. Am J Ind Med 29:533-538.

Arnalich F, Lahoz C, Picazo ML, Monereo A, Arribas JR, Martinez Ara J, Vázquez JJ [1989]. Polyarteritis nodosa and necrotizing glomerulonephritis associated with long-standing silicosis. Nephron 51(4):544-547.

Ashe HB, Bergstrom DE [1964]. Twenty-six years' experience with dust control in the Vermont granite industry. Ind Med Surg 33(1):73-78.

ATS (American Thoracic Society) [1987]. Standards for the diagnosis and care of patients with chronic obstructive pulmonary disease (COPD) and asthma. Am Rev Respir Dis 136:225-244.

ATS (American Thoracic Society) [1995]. Standards for the diagnosis and care of patients with chronic obstructive pulmonary disease. Am J Respir Crit Care Med 152(5):S77-S121.

ATS (American Thoracic Society) [1997]. Adverse effects of crystalline silica exposure. Am J Respir Crit Care Med 155:761-768.

Balmes J [1990]. Silica exposure and tuberculosis: An old problem with some new twists (editorial). J Occup Med 32(2):114-115.

Bang KM, Althouse RB, Kim JH, Game SR, Castellan RM [1995]. Silicosis mortality surveillance in the United States, 1968-1990. Appl Occup Environ Hyg 10(12):1070-1074.

Banks DE [1996]. Clinical features of silicosis. In: Castranova V, Vallyathan V, Wallace WE, eds. Silica and silica-induced lung diseases. Boca Raton, FL: CRC Press, Inc., pp. 23-37.

Banks DE, Milutinovic J, Desnick RJ, Grabowski GA, Lapp NL, Boehlecke BA [1983]. Silicon nephropathy mimicking Fabry's disease. Am J Nephrol 3(5):279284.

Barnhart S [1994]. Irritant bronchitis. In: Rosenstock L, Cullen MR, eds. Textbook of clinical occupational and environmental medicine. Philadelphia, PA: W.B. Saunders Co., pp. 224-232.

Baron PA [2001]. E-mail message on February 15, 2001, from Paul A. Baron to Ralph D. Zumwalde, Education and Information Division, National Institute for Occupational Safety and Health, Centers for Disease Control and Prevention, Public Health Service, U.S. Department of Health and Human Services.

Bartley DL, Chen C-C, Song RS, Fischbach TJ [1994]. Respirable aerosol sampler performance testing. Am Ind Hyg Assoc J 55(11):1036-1046.

Beadle DG, Bradley AA [1970]. The composition of airborne dust in South African gold mines. In: Shapiro HA, ed. Pneumoconiosis: Proceedings of the International Conference. Capetown, South Africa: Oxford University Press, pp. 462-466.

Beaumont JJ, Goldsmith DF, Morrin LA, Schenker MB [1995]. Mortality in agricultural workers after compensation claims for respiratory disease, pesticide illness, and injury. J Occup Environ Med 37(2):160-169.

Becklake MR [1985]. Chronic airflow limitation: Its relationship to work in dusty occupations. Chest $88(4)$ : 608-617.

Becklake MR [1992]. Occupational exposures and chronic airways disease. In: Rom WN, ed. Environmental and occupational medicine. 2nd ed. Boston, MA: Little, Brown and Company, pp. 453-463.

Becklake MR, Irwig L, Kielkowski D, Webster I, De Beer M, Landau S [1987]. The predictors of emphysema in South African gold miners. Am Rev Respir Dis 135:1234-1241.

Belli S, Comba P, Germani D, Grignoli M, Lagorio S, Paganoni R, Ronchin M [1989]. Mortality study among lead-zinc Italian (Val Seriana) miners (in Italian). Med Lav 80(6):467-478.

Bernard AM, Gonzalez-Lorenzo JM, Siles E, Trujillano G, Lauwerys R [1994]. Early decrease of serum Clara cell protein in silica-exposed workers. Eur Respir J 7:1932-1937.

Bernardini P, Iannaccone A [1982]. Pulmonary silicosis associated with systemic lupus erythematosus. Lav Um $30: 8-16$.

Bhaskar R, Li J, Xu L [1994]. A comparative study of particle size dependency of IR and XRD methods for quartz analysis. Am Ind Hyg Assoc J 55(7):605-609.

Blair A, Zahm SH [1991]. Cancer among farmers. Occup Med: State of the Art Rev 6(3):335-354.

Bolsaitis PP, Wallace WE [1996]. The structure of silica surfaces in relation to cytotoxicity. In: Castranova V, 
Vallyathan V, Wallace WE, eds. Silica and silicainduced lung diseases. Boca Raton, FL: CRC Press, Inc., pp. $79-89$.

Bolton WK, Suratt PM, Sturgill BC [1981]. Rapidly progressive silicon nephropathy. Am J Med 71:823-828.

BOM [1992]. Crystalline silica primer. Washington, DC: U.S. Department of the Interior, U.S. Bureau of Mines.

BOM [1994]. Mineral commodity summaries, 1994. Washington, DC: U.S. Department of the Interior, U.S. Bureau of Mines, pp. 137, 144-147.

Bonnin A, Mousson C, Justrabo E, Tanter Y, Chalopin JM, Rifle G [1987]. Silicosis associated with crescentic IgA mesangial nephropathy [letter to the editor]. Nephron 47(3):229-230.

Borm PJA, Bast A, Wouters EFM, Slangen JJ, Swaen GMH, de Boorder T [1986]. Red blood cell anti-oxidant parameters in silicosis. Int Arch Occup Environ Health $58: 235-244$.

Boujemaa W, Lauwerys R, Bernard A [1994]. Early indicators of renal dysfunction in silicotic workers. Scand J Work Environ Health 20(3):180-183.

Bovenzi M, Barbone F, Betta A, Tommasini M, Versini W [1995]. Scleroderma and occupational exposure. Scand J Work Environ Health 21:289-292.

Bramwell B [1914]. Diffuse sclerodermia: Its frequency; its occurrence in stonemasons; its treatment by fibrolysin - elevations of temperature due to fibrolysin injections. Edinburgh Med J 12:387-401.

Brandt-Rauf PW, Smith S, Hemminki K, Koskinen H, Vainio H, Niman H, Ford J [1992]. Serum oncoproteins and growth factors in asbestosis and silicosis patients. Int J Cancer 50:881-885.

Bravo MP, Del Rey Calero J, Conde M [1987]. Silice y cáncer de vejiga en varones. Arch Esp de Urol 40(9): 635-637.

Brown DP, Kaplan SD, Zumwalde RD, Kaplowitz M, Archer VE [1986]. Retrospective cohort mortality study of underground gold mine workers. In: Goldsmith DF, Winn DM, Shy CM, eds. Silica, silicosis, and cancer. Controversy in occupational medicine, Cancer Research Monographs, Vol. 2. New York: Praeger Publishers, pp. 335-350.
Brown LM, Gridley G, Olsen JH, Mellemkjær L, Linet MS, Fraumeni JF Jr. [1997]. Cancer risk and mortality patterns among silicotic men in Sweden and Denmark. J Occup Environ Med 39(7):633-638.

Bureau of the Census [1986]. County business patterns, 1986 (state files and public use data tapes). Washington, DC: U.S. Department of Commerce.

Bureau of the Census [1993]. County business patterns, 1993 (state files and public use data tapes). Washington, DC: U.S. Department of Commerce, Bureau of the Census.

Bureau of the Census [1997]. Statistical abstract of the United States, 1997, 117th ed. Washington, DC: U.S. Department of Commerce. Government Printing Office, Table No. 645, pp. 410-412.

Burgess GL, Turner S, McDonald JC, Cherry NM [1997]. Cohort mortality study of Staffordshire pottery workers: (I) Radiographic validation of an exposure matrix for respirable crystalline silica. Ann Occup Hyg 41(Suppl 1):403-407.

Burns CJ, Laing TJ, Gillespie BW, Heeringa SG, Alcser KH, Mayes MD, Wasko MCM, Cooper BC, Garabrant DH, Schottenfeld D [1996]. The epidemiology of scleroderma among women: Assessment of risk from exposure to silicone and silica. J Rheumatol 23(11):19041911.

Burrows B [1986]. Pulmonary function testing. In: Merchant JA, Boehlecke BA, Taylor G, Pickett-Harner M, eds. Occupational respiratory diseases. Cincinnati, $\mathrm{OH}$ : U.S. Department of Health and Human Services, Public Health Service, Centers for Disease Control, National Institute for Occupational Safety and Health, DHHS (NIOSH) Publication No. 86-102, p. 162.

Calhoun WJ, Christman JW, Ershler WB, Graham WGB, Davis GS [1986]. Raised immunoglobulin concentrations in bronchoalveolar lavage fluid of healthy granite workers. Thorax 41:266-273.

Calvert GM, Steenland K [1997]. Occupational exposure to silica and end-stage renal disease [letter to the editor]. J Am Med Assoc 278(7):547.

Calvert GM, Steenland K, Palu S [1997]. End-stage renal disease among silica-exposed gold miners: A new method for assessing incidence among epidemiologic cohorts. J Am Med Assoc 277(15):1219-1223. 
Canessa PA, Torraca A, Lavecchia MA, Patelli M, Poletti V [1990]. Pneumoconiosis (silicosis) in the confectionery industry. Sarcoidosis 7(1):75-77.

Cantwell MF, McKenna MT, McCray E, Onorato IM [1998]. Tuberculosis and race/ethnicity in the United States: Impact of socioeconomic status. Am J Respir Crit Care Med 157:1016-1020.

Carel RS, Salman H, Bar-Ziv J [1994]. "Souvenir” casting silicosis. Chest 106(4):1272-1274.

Carta P, Cocco PL, Casula D [1991]. Mortality from lung cancer among Sardinian patients with silicosis. Br J Ind Med 48(2):122-129.

Castranova V, Dalal NS, Vallyathan V [1996]. Role of surface free radicals in the pathogenicity of silica. In: Castranova V, Vallyathan V, Wallace WE, eds. Silica and silica-induced lung diseases. Boca Raton, FL: CRC Press, Inc., pp. 91-105.

Castranova V, Vallyathan V, Ramsey DM, McLaurin JL, Pack D, Leonard S, Barger MW, Ma JYC, Dalal NS, Teass A [1997]. Augmentation of pulmonary reactions to quartz inhalation by trace amounts of iron-containing particles. Environ Health Perspect 105(Suppl 5):1319 1324.

Caux F, Chosidow O, De Cremoux H, Roujeau JC, Revuz J [1991]. The dental prosthetist, a person at risk of silicosis-associated scleroderma: A case. Ann Dermatol Venereol 118:301-304.

CDC (Centers for Disease Control and Prevention) [1995]. Proportionate mortality from pulmonary tuberculosis associated with occupations - 28 states, 1979 1990. MMWR 44(1):14-19.

CDC (Centers for Disease Control and Prevention) [1998a]. Silicosis deaths among young adults-United States, 1968-1994. MMWR 47(16):331-335.

CDC (Centers for Disease Control and Prevention) [1998b]. Silicosis deaths among young adults-United States, 1968-1994. J Am Med Assoc 280(1):13-15.

CDC (Centers for Disease Control and Prevention) [1998c]. Recommendations for prevention and control of tuberculosis among foreign-born persons: Report of the working group on tuberculosis among foreign-born persons. MMWR 47(RR-16):1-29.
CFR. Code of Federal regulations. Washington, DC: U.S. Government Printing Office, Office of the Federal Register.

Chan-Yeung M [1994]. Asthma. In: Rosenstock L, Cullen MR, eds. Textbook of clinical, occupational, and environmental medicine. Philadelphia, PA: W.B. Saunders Co., pp. 197-209.

Chatgidakis CB [1963]. Silicosis in South African white gold miners: A comparative study of the disease in its different stages. South Afr J Adv Med Sci 9:383-392.

Checkoway H [1995]. Methodological considerations relevant to epidemiology studies of silica and lung cancer. Appl Occup Environ Hyg 10(12):1049-1055.

Checkoway H, Rice CH [1992]. Time-weighted averages, peaks, and other indices of exposure in occupational epidemiology. Am J Ind Med 21:25-33.

Checkoway H, Pearce N, Crawford-Brown DJ [1989]. Monographs in epidemiology and biostatistics: Research methods in occupational epidemiology. Vol. 13. New York: Oxford University Press.

Checkoway H, Heyer NJ, Demers PA, Breslow NE [1993]. Mortality among workers in the diatomaceous earth industry. Br J Ind Med 50:586-597.

Checkoway H, Heyer NJ, Demers PA, Gibbs GW [1996]. Reanalysis of mortality from lung cancer among diatomaceous earth industry workers, with consideration of potential confounding by asbestos exposure. Occup Environ Med 53:645-647.

Checkoway H, Heyer NJ, Seixas NS, Welp EAE, Demers PA, Hughes JM, Weill H [1997]. Dose-response associations of silica with nonmalignant respiratory disease and lung cancer mortality in the diatomaceous earth industry. Am J Epidemiol 145(8):680-688.

Checkoway H, Hughes JM, Weill H, Seixas NS, Demers PA [1999]. Crystalline silica exposure, radiological silicosis, and lung cancer mortality in diatomaceous earth industry workers. Thorax 54(1):56-59.

Chen J, McLaughlin JK, Zhang J-Y, Stone BJ, Luo J, Chen R-A, Dosemeci M, Rexing SH, Wu Z, Hearl FJ, McCawley MA, Blot WJ [1992]. Mortality among dust-exposed Chinese mine and pottery workers. J Occup Med 34(3):311-316.

Chen GX, Burnett CA, Cameron LL, Alterman T, Lalich NR, Tanaka S, Althouse RB [1997]. Tuberculosis 
mortality and silica exposure: A case-control study based on a national mortality database for the years 1983-1992. Int J Occup Environ Health 3(3):163-170.

Cherry N, Burgess G, McNamee R, Turner S, McDonald $C$ [1995]. Initial findings from a cohort mortality study of British pottery workers. Appl Occup Environ Hyg 10(12):1042-1045.

Cherry NM, Burgess GL, Turner S, McDonald JC [1997]. Cohort study of Staffordshire pottery workers: (II) Nested case referent analysis of lung cancer. Ann Occup Hyg 41(Suppl 1):408-411.

Cherry NM, Burgess GL, Turner S, McDonald JC [1998]. Crystalline silica and risk of lung cancer in the potteries. Occup Environ Med 55:779-785.

Clark TC, Harrington VA, Asta J, Morgan WKC, Sargent EN [1980]. Respiratory effects of exposure to dust in taconite mining and processing. Am Rev Respir Dis 121:959-966.

Cledes J, Herve JP, Youinou P, Clavier J [1982]. Pulmonary silicosis and disseminated lupus erythematous lupus with nephropathy [letter to the editor]. Nouv Presse Med 11(19):1498.

Clementsen P, Høegholm A, Pedersen C [1986]. Hepatic silicosis. Ugeskr Laeger 148(10):587-588.

Cocco P, Ward MH, Buiatti E [1996]. Occupational risk factors for gastric cancer: An overview. Epidemiol Rev 18(2):218-234.

Cointrel C, Tillie-Leblond I, Lamblin C, Furon D, Tonnel A-B, Wallaert B [1997]. Erasmus syndrome: Clinical characteristics, computer tomography, respiratory function and bronchoalveolar lavage findings. Rev Mal Respir 14:21-26.

Committee on Biological Markers of the National Research Council [1987]. Biological markers in environmental health research. Environ Health Perspect 74:3-9.

Corbett EL, Churchyard GJ, Clayton T, Herselman P, Williams B, Hayes R, Mulder D, De Cock KM [1999]. Risk factors for pulmonary mycobacterial disease in South African gold miners. Am J Respir Crit Care Med 159:94-99.

Corn JK [1980]. Historical aspects of industrial hygiene. II. Silicosis. Am Ind Hyg Assoc J 41(2):125-133.
Costello J [1983]. Mortality of metal miners-a retrospective cohort and case-control study. In: Wagner WL, Rom WN, Merchant JA, eds. Health issues related to metal and nonmetallic mining. Boston, MA: Butterworth Publishers, pp. 226-240.

Costello J, Graham WGB [1988]. Vermont granite workers' mortality study. Am J Ind Med 13:483-497.

Costello J, Castellan RM, Swecker GS, Kullman GJ [1995]. Mortality of a cohort of U.S. workers employed in the crushed stone industry, 1940-1980. Am J Ind Med 27:625-640.

Cowie RL [1987]. Silica-dust-exposed mine workers with scleroderma (systemic sclerosis). Chest 92(2):260262.

Cowie RL [1994]. The epidemiology of tuberculosis in gold miners with silicosis. Am J Respir Crit Care Med 150:1460-1462.

Cowie RL, Mabena SK [1991]. Silicosis, chronic airflow limitation, and chronic bronchitis in South African gold miners. Am Rev Respir Dis 143:80-84.

Cowie RL, Hay M, Thomas RG [1993]. Association of silicosis, lung dysfunction, and emphysema in gold miners. Thorax 48:746-749.

Coyle TD [1982]. Silica. In: Grayson M, Eckroth D, eds. Kirk-Othmer encyclopedia of chemical technology. 3rd ed. Vol. 20. New York: Wiley-Interscience Publishers, pp. $748-766$.

Craighead J [1996]. Pathogenic considerations regarding disease related to silica dust exposure. In: Castranova V, Vallyathan V, Wallace WE, eds. Silica and silica-induced lung diseases. Boca Raton, FL: CRC Press, Inc., pp. 3-6.

Crapo RO [1994]. Pulmonary-function testing. N Engl J Med 331(1):25-30.

CSTE [1996]. Adding silicosis as a condition reportable to the National Public Health Surveillance system (NPHSS). Council of State and Territorial Epidemiologists, Position Statement No. 2.

Dagle GE, Wehner AP, Clark ML, Buschbom RL [1986]. Chronic inhalation exposure of rats to quartz. In: Goldsmith DF, Winn DM, Shy CM, eds. Silica, silicosis, and cancer. Controversy in occupational medicine, cancer research monographs. Vol. 2. New York: Praeger, pp. 255-266. 
Daniel LN, Mao Y, Saffiotti U [1993]. Oxidative DNA damage by crystalline silica. Free Radic Biol Med 14: 463-472.

Daniel LN, Mao Y, Wang T-CL, Markey CJ, Markey SP, Shi X, Saffiotti U [1995]. DNA strand breakage, thymine glycol production, and hydroxyl radical generation induced by different samples of crystalline silica in vitro. Environ Res 71:60-73.

Davis GS [1991]. Immunologic aspects of pneumoconioses in asbestosis and silicosis. In: Lynch JP III, DeRemee RA, eds. Immunologically mediated pulmonary diseases. Philadelphia, PA: J.B. Lippincott Company, pp. 111-155.

Davis GS [1996]. Silica. In: Harber P, Schenker MB, Balmes JR, eds. Occupational and environmental respiratory disease. 1st ed. St. Louis, MO: Mosby-Year Book, Inc., pp. 373-399.

Davis LK, Wegman DH, Monson RR, Froines J [1983]. Mortality experience of Vermont granite workers. Am J Ind Med 4:705-723.

de Bandt M, Meyer O, Palazzo E, Belmatoug N, Kahn MF [1991]. Erasmus syndrome and evolutive atheromatosis of great trunks. Revue du Rhumatisme 58(12): 893-894.

de Barros Hatem EJ, Cavalcanti FMTB [1990]. Silicosis in pit diggers in Serra da Ibiapaba, Ceara, Brazil. Proceedings of the VIIth International Pneumoconioses Conference. Part II. Cincinnati, OH: U.S. Department of Health and Human Services, Public Health Service, Centers for Disease Control, National Institute for Occupational Safety and Health, DHHS (NIOSH) Publication No. 90-108, Part II, pp. 1316-1319.

Decoufle P, Wood DJ [1979]. Mortality patterns among workers in a gray iron foundry. Am J Epidemiol 109(6): 667-675.

de Klerk NH, Musk AW [1998]. Silica, compensated silicosis, and lung cancer in Western Australian goldminers. Occup Environ Med 55:243-248.

DHHS [1985]. Chapter 8- Silica-exposed workers. In: The health consequences of smoking-cancer and chronic lung disease in the workplace: A report of the Surgeon General. Rockville, MD: U.S. Department of Health and Human Services, Public Health Service, Office on Smoking and Health, pp. 317-354.
Dockery DW, Speizer FE, Ferris BG Jr., Ware JH, Louis TA, Spiro A III [1988]. Cumulative and reversible effects of lifetime smoking on simple tests of lung function in adults. Am Rev Respir Dis 137:286-292.

DOL [1996]. Press release on joint campaign on silicosis prevention: Labor Secretary calls for an end to silicosis. Washington, DC: Department of Labor, Office of Public Affairs, October 31.

DOL, NIOSH [1997]. A guide to working safely with silica. Washington, DC: U.S. Government Printing Office, Document 550-561/60917.

Donaldson K, Borm PJA [1998]. The quartz hazard: A variable entity. Ann Occup Hyg 42(5):287-294.

Dong D, Xu G, Sun Y, Hu P [1995]. Lung cancer among workers exposed to silica dust in Chinese refractory plants. Scand J Work Environ Health 21(Suppl 2): 69-72.

Dracon M, Noël C, Wallaert BP, Dequiedt P, Lelièvre G, Tacquet A [1990]. Rapidly progressive glomerulonephritis in silicotic coal miners. Nephrologie 11:61-65.

Drew RT, Kutzman RS [1984a]. Final report on a study of Fischer 344 rats exposed to silica dust for six months at concentrations of $0,2,10$ or $20 \mathrm{mg} / \mathrm{m}^{3}$, then maintained for six months prior to assessment. Report No. BNL 35735. Upton, NY: Brookhaven National Laboratory, Interagency Agreement No. 222-Y01ES-9-0043.

Drew RT, Kutzman RS [1984b]. Final report on a study of Fischer-344 rats exposed to silica dust for six months at concentrations of $0,2,10$ or $20 \mathrm{mg} / \mathrm{m}^{3}$. Report No. BNL 34617. Upton, NY: Brookhaven National Laboratory, Interagency Agreement No. 222-Y01ES-9-0043.

Driscoll KE [1996]. The role of interleukin-1 and tumor necrosis factor $\alpha$ in the lung's response to silica. In: Castranova V, Vallyathan V, Wallace WE, eds. Silica and silica-induced lung diseases. Boca Raton, FL: CRC Press, Inc., pp. 163-184.

Driscoll KE, Deyo LC, Howard BW, Poynter J, Carter JM [1995]. Characterizing mutagenesis in the hprt gene of rat alveolar epithelial cells. Exp Lung Res 21:941956.

Driscoll KE, Deyo LC, Carter JM, Howard BW, Hassenbein DG, Bertram TA [1997]. Effects of particle exposure and particle-elicited inflammatory cells on 
mutation in rat alveolar epithelial cells. Carcinogenesis 18(2):423-430.

Dubrow R, Gute DM [1987]. Cause-specific mortality among Rhode Island jewelry workers. Am J Ind Med 12:579-593.

Ducatman BS, Cox-Ganser J, Dosemeci M, Ducke G, Erren T, Hubbs AF, Jacobsen M, McCawley M, Morfeld P, Ong T-M, Otten H, Piekarski C, Rothman N, Saffiotti U, Schulz H, Vallyathan V [1997]. A new way to look at old questions of silica carcinogenicity. Appl Occup Environ Hyg 12(12):919-923.

Dufresne A, Bégin R, Dion C, Jagirdar J, Rom WN, Loosereewanich P, Muir DCF, Ritchie AC, Perrault G [1998]. Angular and fibrous particles in lung in relation to silica-induced diseases. Int Arch Occup Environ Health 71:263-269.

Dynnik VI, Khizhnyakova LN, Baranenko AA, Makotchenko VM, Oksenyuk IM, Shcheynin BY, Kondratayeva EA, Guzeeva AM [1981]. Silicosis in tractor drivers working on sandy soils in forestries. Gig Trud Prof Zabol (12):26-28.

Ebihara I [1982]. Clinical study on autoimmune diseases associated with pneumoconiosis. Allergy 31(3): 189-199.

Eisen EA, Wegman DH, Louis TA [1983]. Effects of selection in a prospective study of forced expiratory volume in Vermont granite workers. Am Rev Respir Dis 128:587-591.

Eisen EA, Wegman DH, Louis TA, Smith TJ, Peters JM [1995]. Healthy worker effect in a longitudinal study of one-second forced expiratory volume $\left(\mathrm{FEV}_{1}\right)$ and chronic exposure to granite dust. Int J Epidemiol 24(6): 1154-1162.

Eller PM, Key-Schwartz RJ, Song RS, Edwards SL, Schlecht PC [1999a]. Silica method modifications for improved interlaboratory precision. Synergist, November:23-24.

Eller PM, Feng HA, Song RS, Key-Schwartz RJ, Esche CA, Groff JH [1999b]. Proficiency analytical testing (PAT) silica variability, 1990-1998. Am Ind Hyg Assoc J 60(July/August):533-539.

Elmes PC [1994]. Inorganic dusts. In: Raffle PAB, Adams PH, Baxter PJ, Lee WR, eds. Hunter's diseases of occupations. 8th ed. London: Edward Arnold Publishers, pp. $410-457$.
EPA [1996]. Ambient levels and noncancer health effects of inhaled crystalline and amorphous silica: Health issue assessment. Washington, DC: U.S. Environmental Protection Agency, Office of Research and Development, National Center for Environmental Assessment, Publication No. EPA/600/R-95/115.

Erasmus LD [1957]. Scleroderma in gold-miners on the Witwatersrand with particular reference to pulmonary manifestations. South African J Lab Clin Med 3(3):209231.

Erdogdu G, Hasirci V [1998]. An overview of the role of mineral solubility in silicosis and asbestosis. Environ Res 78:38-42.

European Standardization Committee (CEN) [1993]. Workplace atmospheres - size fraction definitions for measurement of airborne particles. Brussels, Belgium: European Standardization Committee (CEN), BS EN 481.

Fairfax R [1998]. Exposures to respirable silica during relining of furnaces for molten metals. Appl Occup Environ Hyg 13(7):508-510.

Fanburg BL [1992]. Sarcoidosis. In: Wyngaarden JB, Smith LH Jr., Bennett JC, eds. Cecil textbook of medicine. 19th ed. Vol. 1. Philadelphia, PA: W.B. Saunders Company, pp. 430-435.

54 Fed. Reg. 2521 [1989]. Occupational Safety and Health Administration: Air contaminants; final rule; silica, crystalline-quartz. (Codified at 29 CFR 1910.)

Fennerty A, Hunter AM, Smith AP, Pooley FD [1983]. Silicosis in a Pakistani farmer. Br Med J 287:648-649.

Finkelstein M, Kusiak R, Suranyi G [1982]. Mortality among miners receiving workmen's compensation for silicosis in Ontario: 1940-1975. J Occup Med 24(9):663-667.

Forastiere F, Lagorio S, Michelozzi P, Perucci CA, Axelson O [1989]. Mortality pattern of silicotic subjects in the Latium region, Italy. Br J Ind Med 46(12):877880 .

Foxman B, Higgins ITT, Oh MS [1986]. The effects of occupation and smoking on respiratory disease mortality. Am Rev Respir Dis 134:649-652.

Freeman CS, Grossman EA [1995]. Silica exposures in the United States between 1980 and 1992. Scand J Work Environ Health 21(Suppl 2):47-49. 
Froines JR, Wegman DH, Dellenbaugh CA [1986]. An approach to the characterization of silica exposure in U.S. industry. Am J Ind Med 10(4):345-361.

Frommel D, Ayranci B, Pfeifer HR, Sanchez A, Frommel A, Mengistu G [1993]. Podoconiosis in the Ethiopian Rift Valley: Role of beryllium and zirconium. Trop Geogr Med 45(4):165-167.

Fubini B [1997]. Surface reactivity in the pathogenic response to particulates. Environ Health Perspect 105(Suppl 5):1013-1020.

Fubini B [1998]. Surface chemistry and quartz hazard. Ann Occup Hyg 42(8):521-530.

Fukata S, Matsubayashi S, Nagato H, Sakai K, Ohishi S, Yasuda M, Tamai H, Nakagawa T [1983]. Study on monoclonal gammopathies associated with silicosis. Rinsho Ketsueki 24(1):9-17.

Fukata S, Tamai H, Nagai K, Matsubayashi S, Nagato H, Tashiro T, Yasuda M, Kumagai LF [1987]. A patient with hereditary spherocytosis and silicosis who developed an IgA(lambda) monoclonal gammopathy. Jpn J Med 26(1):81-83.

Fulekar MH, Alam Khan MM [1995]. Occupational exposure to dust in slate pencil manufacture. Ann Occup Hyg 39(1):107-114.

Fyfe NCM, Price EW [1985]. The effects of silica on lymph nodes and vessels: A possible mechanism in the pathogenesis of non-filarial endemic elephantiasis. Transactions of the Royal Society of Tropical Medicine and Hygiene 79:645-651.

Gáliková E [1982]. Immunoglobulin levels in colliers and miners in central Slovakia. Prac Lék 34(3):83-85.

Gao H, Brick J, Ong S, Miller M, Whong W-Z, Ong T [1997]. Selective hyperexpression of $c$-jun oncoprotein by glass fiber- and silica-transformed BALB/c-3T3 cells. Cancer Lett 112:65-69.

Giles RD, Sturgill BC, Suratt PM, Bolton WK [1978]. Massive proteinuria and acute renal failure in a patient with acute silicoproteinosis. Am J Med 64:336-342.

Goldsmith DF [1994a]. Health effects of silica dust exposure. In: Heaney PJ, Prewitt CT, Gibbs GV, eds. Reviews in mineralogy. Silica: Physical behavior, geochemistry, and materials applications. Vol. 29. Washington, DC: Mineralogical Society of America, pp. 545-606.
Goldsmith DF [1994b]. Silica exposure and pulmonary cancer. In: Samet JM, ed. Epidemiology of lung cancer. New York: Marcel Dekker, Inc., pp. 245-298.

Goldsmith DF [1998]. Uses of workers' compensation data in epidemiology research. Occup Med: State of the Art Rev 13(2):389-415.

Goldsmith DF, Guidotti TL, Johnston DR [1982]. Does occupational exposure to silica cause lung cancer? Am J Ind Med 3:423-440.

Goldsmith DF, Winn DM, Shy CM, eds. [1986]. Silica, silicosis, and cancer: Controversy in occupational medicine. New York: Praeger Publishers.

Goldsmith DF, Beaumont JJ, Morrin LA, Schenker MB [1995]. Respiratory cancer and other chronic disease mortality among silicotics in California. Am J Ind Med 28(4):459-467.

Goldstein B, Webster I [1976]. The obligations of medical practitioners in relation to the New Mines and Works Act. S Afr Med J 50:975-977.

Gordon RL, Franklin RE [1956]. Gasses, liquids, and disordered structures. Br J Appl Physics 7:389-394.

Graham WGB [1992]. Silicosis. Clin Chest Med 13(2): 253-267.

Graham WGB [1998]. Quartz and silicosis. In: Banks DE, Parker JE, eds. Occupational lung disease. London: Chapman \& Hall, pp. 191-212.

Graham WGB, O'Grady RV, Dubuc B [1981]. Pulmonary function loss in Vermont granite workers: A long-term follow-up and critical reappraisal. Am Rev Respir Dis 123:25-28.

Graham WGB, Ashikaga T, Hemenway D, Weaver S, O'Grady RV [1991]. Radiographic abnormalities in Vermont granite workers exposed to low levels of granite dust. Chest 100(6):1507-1514.

Graham WGB, Weaver S, Ashikaga T, O'Grady RV [1994]. Longitudinal pulmonary function losses in Vermont granite workers: A reevaluation. Chest 106(1): 125-130.

Graham WGB, Muir DC, Morgan WK, Vacek P, Sisco-Cheng B [1998]. Radiographic abnormalities on retired Vermont granite workers and the permissible exposure limits for crystalline silica [Abstract]. Chest 114(4S):282. 
Green FHY, Vallyathan V [1996]. Pathologic responses to inhaled silica. In: Castranova V, Vallyathan V, Wallace WE eds. Silica and silica-induced lung diseases. Boca Raton, FL: CRC Press, pp. 39-59.

Greskevitch MF, Turk AR, Dieffenbach AL, Roman JM, Groce DW, Hearl FJ [1992]. Quartz analyses of the bulk dust samples collected by the National Occupational Health Survey of Mining. Appl Occup Environ Hyg 7(8):527-531.

Groth DH, Stettler LE, Platek SF, Lal JB, Burg JR [1986]. Lung tumors in rats treated with quartz by intratracheal instillation. In: Goldsmith DF, Winn DM, Shy CM, eds. Silica, silicosis, and cancer: Controversy in occupational medicine. Cancer Research Monographs, Vol. 2. New York: Praeger, pp. 243-253.

Gu Z-W, Ong T [1996]. Potential mechanisms of silicainduced cancer. In: Castranova V, Vallyathan V, Wallace WE, eds. Silica and silica-induced lung diseases. Boca Raton, FL: CRC Press, pp. 397-406.

Gualde N, De Leobardy J, Serizay B, Malinvaud G [1977]. HL-A and silicosis. Am Rev Respir Dis 116: 334-336.

Guénel P, Højberg G, Lynge E [1989]. Cancer incidence among Danish stone workers. Scand J Work Environ Health 15:265-270.

Guseva NG [1991]. Induced scleroderma. Revmatologiia $0(1): 33-37$.

Guthrie GD Jr. [1997]. Mineral properties and their contributions to particle toxicity. Environ Health Perspect 105(Suppl 5):1003-1011.

Guthrie GD Jr., Heaney PJ [1995]. Mineralogical characteristics of silica polymorphs in relation to their biological activities. Scand J Work Environ Health 21(Suppl 2):5-8.

Haslam PL [1994]. Basic immunology and immunopathology. In: Parkes WR, ed. Occupational lung disorders. 3rd ed. London: Butterworth-Heinemann Publishers, pp. 50-99.

Hatron P-Y, Plouvier B, Francois M, Baclet J-L, Deconninck P, Devulder B [1982]. Association of lupus erythematosus and silicosis. Rev Med Interne 3(3): 245-246.
Hauglustaine D, Van Damme B, Daenens P, Michielsen P [1980]. Silicon nephropathy: A possible occupational hazard. Nephron 26:219-224.

Haustein U-F [1998]. Silica-induced lupus erythematosus [letter to the editor]. Acta Derm Venereol (Stockh) 78:73-74.

Haustein U-F, Anderegg U [1998]. Silica induced scleroderma-clinical and experimental aspects. J Rheumatol 25(10):1917-1926.

Haustein U-F, Ziegler V, Herrmann K, Mehlhorn J, Schmidt C [1990]. Silica-induced scleroderma. J Am Acad Dermatol 22(3):444-448.

Haustein U-F, Ziegler V, Herrmann K [1992]. Chemically induced scleroderma. Der Hautarzt 43:464-474.

Hayes RB, Dosemeci M, Riscigno M, Blair A [1993]. Cancer mortality among jewelry workers. Am J Ind Med 24:743-751.

Hayhurst MD, Flenley DC, McLean A, Wightman AJA, MacNee W, Wright D, Lamb D, Best J [1984]. Diagnosis of pulmonary emphysema by computerised tomography. Lancet 8398:320-322.

Heaney PJ [1994]. Structure and chemistry of the low-pressure silica polymorphs. In: Heaney PJ, Prewitt CT, Gibbs GV, eds. Silica: Physical behavior, geochemistry, and materials applications. Reviews in mineralogy. Vol. 29. Washington, DC: Mineralogical Society of America, pp.1-40.

Hearl FJ [1996]. Guidelines and limits for occupational exposure to crystalline silica. In: Castranova V, Vallyathan V, Wallace WE eds. Silica and silica-induced lung diseases. Boca Raton, FL: CRC Press, Inc., pp. $15-22$.

Hemley RJ, Prewitt CT, Kingma KJ [1994]. Highpressure behavior of silica. In: Heaney PJ, Prewitt CT, Gibbs GV, eds. Silica: Physical behavior, geochemistry, and materials applications. Reviews in mineralogy. Vol. 29. Washington, DC: Mineralogical Society of America, pp. 41-81.

Heppleston AG [1984]. Pulmonary toxicology of silica, coal and asbestos. Environ Health Perspect 55:111-127.

Heppleston AG [1994]. Pathogenesis of mineral pneumoconioses. In: Parkes WR, ed. Occupational lung disorders. 3rd ed. London: Butterworth-Heinemann Publishers, pp. 100-134. 
Hessel PA, Sluis-Cremer GK, Hnizdo E, Faure MH, Thomas RG, Wiles FJ [1988]. Progression of silicosis in relation to silica dust exposure. Ann Occup Hyg 32(Suppl 1):689-696.

Hesterberg TW, Barrett JC [1984]. Dependence of asbestos- and mineral dust-induced transformation of mammalian cells in culture on fiber dimension. Cancer Res 44:2170-2180.

Hesterberg TW, Oshimura M, Brody AR, Barrett JC [1986]. Asbestos and silica induce morphological transformation of mammalian cells in culture: A possible mechanism. In: Goldsmith DF, Winn DM, Shy CM, eds. Silica, silicosis, and cancer: Controversy in occupational medicine. Cancer Research Monographs. Vol. 2. New York: Praeger Publishers, pp. 177-190.

Hnizdo E [1992]. Loss of lung function associated with exposure to silica dust and with smoking and its relation to disability and mortality in South African gold miners. Br J Ind Med 49:472-479.

Hnizdo E [1995]. Risk of silicosis: Comparison of South African and Canadian miners [letter to the editor]. Am J Ind Med 27:619-622.

Hnizdo E, Murray J [1998]. Risk of pulmonary tuberculosis relative to silicosis and exposure to silica dust in South African gold miners. Occup Environ Med 55:496-502.

Hnizdo E, Murray J [1999]. Risk of pulmonary tuberculosis relative to silicosis and exposure to silica dust in South African gold miners [correction]. Occup Environ Med 56:215-216.

Hnizdo E, Sluis-Cremer GK [1991]. Silica exposure, silicosis, and lung cancer: A mortality study of South African gold miners. Br J Ind Med 48:53-60.

Hnizdo E, Sluis-Cremer GK [1993]. Risk of silicosis in a cohort of white South African gold miners. Am J Ind Med 24:447-457.

Hnizdo E, Sluis-Cremer GK, Abramowitz JA [1991]. Emphysema type in relation to silica dust exposure in South African gold miners. Am Rev Respir Dis 143:1241-1247.

Hnizdo E, Murray J, Sluis-Cremer GK, Thomas RG [1993]. Correlation between radiological and pathological diagnosis of silicosis: An autopsy population based study. Am J Ind Med 24:427-445.
Hnizdo E, Sluis-Cremer GK, Baskind E, Murray J [1994]. Emphysema and airway obstruction in non-smoking South African gold miners with long exposure to silica dust. Occup Environ Med 51:557-563.

Hnizdo E, Murray J, Klempman S [1997]. Lung cancer in relation to exposure to silica dust, silicosis and uranium production in South African gold miners. Thorax 52:271-275.

Holland LM [1995]. Animal studies of crystalline silica: Results and uncertainties. Appl Occup Environ Hyg 10(12):1099-1103.

Holland LM, Gonzales M, Wilson JS, Tillery MI [1983]. Pulmonary effects of shale dusts in experimental animals. In: Wagner WL, Rom WN, Merchant JA, eds. Health issues related to metal and nonmetallic mining. Boston, MA: Butterworth Publishers, pp. 485-496.

Holland LM, Wilson JS, Tillery MI, Smith DM [1986]. Lung cancer in rats exposed to fibrogenic dusts. In: Goldsmith DF, Winn DM, Shy CM, eds. Silica, silicosis, and cancer: Controversy in occupational medicine, Cancer Research Monographs. Vol. 2. New York: Praeger, pp. 267-279.

Holman CDJ, Psaila-Savona P, Roberts M, McNulty JC [1987]. Determinants of chronic bronchitis and lung dysfunction in Western Australian gold miners. Br J Ind Med 44:810-818.

Honda K, Kimura A, Dong R-P, Tamai H, Nagato H, Nishimura Y, Sasazuki T [1993]. Immunogenetic analysis of silicosis in Japan. Am J Respir Cell Mol Biol $8(1): 106-111$.

Hook GER, Viviano CJ [1996]. Acute silicosis and the activation of alveolar type II cells. In: Castranova V, Vallyathan V, Wallace WE eds. Silica and silica-induced lung diseases. Boca Raton, FL: CRC Press, Inc., pp. 229-242.

Hosey AD, Trasko VM, Ashe HB [1957]. Control of silicosis in Vermont granite industry: Progress report. Washington, DC: U.S. Department of Health, Education, and Welfare, Public Health Service, Bureau of State Services, Division of Special Health Services, Occupational Health Program, Public Health Service Publication No. 557.

Hotz P, Gonzalez-Lorenzo J, Siles E, Trujillano G, Lauwerys R, Bernard A [1995]. Subclinical signs of kidney dysfunction following short exposure to silica in the absence of silicosis. Nephron 70:438-442. 
HSE [1984]. Quartz in respirable airborne dusts: Laboratory method using infra-red spectroscopy $(\mathrm{KBr}$ disc technique): MDHS 38. In: Methods for the determination of hazardous substances. London: Health and Safety Executive.

HSE [1987]. Quartz in respirable airborne dusts: Laboratory method using infra-red spectroscopy (direct method): MDHS 37. In: Methods for the determination of hazardous substances. London: Health and Safety Executive.

HSE [1988]. Quartz in respirable airborne dusts: Laboratory method using X-ray diffraction (direct method): MDHS 51/2. In: Methods for the determination of hazardous substances. London: Health and Safety Executive.

Hua F, Xipeng J, Shunzhang Y, Xueqi G, Kaiguo W, JianY, Shenghua Q [1992]. Quantitative risk assessment for lung cancer from exposure to metal ore dust. Biomed Environ Sci 5:221-228.

Hughes JM [1995]. Radiographic evidence of silicosis in relation to silica exposure. Appl Occup Environ Hyg 10(12):1064-1069.

Hughes JM, Weill H [1995]. Silicosis risk: Canadian and South African miners [letter to the editor]. Am J Ind Med 27:617-618.

Hughes JM, Weill H, Checkoway H, Jones RN, Henry MM, Heyer NJ, Seixas NS, Demers PA [1998]. Radiographic evidence of silicosis risk in the diatomaceous earth industry. Am J Respir Crit Care Med 158:807-814.

Husgafvel-Pursiainen K, Kannio A, Oksa P, Suitiala T, Koskinen H, Partanen R, Hemminki K, Smith S, Rosenstock-Leibu R, Brandt-Rauf PW [1997]. Mutation, tissue accumulations, and serum levels of p53 in patients with occupational cancers from asbestos and silica exposure. Environ Mol Mutagen 30:224-230.

Hurst VJ, Schroeder PA, Styron RW [1997]. Accurate quantification of quartz and other phases by powder X-ray diffractometry. Anal Chim Acta 337:233-252.

IARC [1987]. IARC monographs on the evaluation of the carcinogenic risk of chemicals to humans: Silica and some silicates. Vol. 42. Lyon, France: World Health Organization, International Agency for Research on Cancer.
IARC [1997]. IARC monographs on the evaluation of carcinogenic risks to humans: Silica, some silicates, coal dust and para-aramid fibrils. Vol 68. Lyon, France: World Health Organization, International Agency for Research on Cancer.

Iler RK [1979]. The chemistry of silica: Solubility, polymerization, colloid and surface properties, and biochemistry. New York: Wiley-Interscience Publishers.

ILO [1980]. Guidelines for the use of ILO international classification of radiographs of pneumoconioses. Rev. ed. Geneva, Switzerland: International Labour Office, Occupational Safety and Health Series No. 22, 48 pp.

ILO [1991]. Occupational lung diseases: Prevention and control. Geneva, Switzerland: International Labour Office, Occupational Safety and Health Series No. 67, 85 pp.

International Organization for Standardization (ISO) [1995]. Air quality: Particle size fraction definitions for health-related sampling. Geneva, Switzerland: International Organization for Standardization, ISO 7708.

Iyer R, Holian A [1996]. Immunological aspects of silicosis. In: Castranova V, Vallyathan V, Wallace WE eds. Silica and silica-induced lung diseases. Boca Raton, FL: CRC Press, Inc., pp. 253-267.

Jain SM, Sepaha GC, Khare KC, Dubey VS [1977]. Silicosis in slate pencil workers: A clinicoradiologic study. Chest 71(3):423-426.

Jones RN, Turner-Warwick M, Ziskind M, Weill H [1976]. High prevalence of antinuclear antibodies in sandblasters' silicosis. Am Rev Respir Dis 113:393395.

Kallenberg CGM [1995]. Renal disease - another effect of silica exposure? Nephrol Dial Transplant 10:11171119.

Kane AB [1996]. Questions and controversies about the pathogenesis of silicosis. In: Castranova V, Vallyathan V, Wallace WE, eds. Silica and silica-induced lung diseases. Boca Raton, FL: CRC Press, Inc., pp. 121-136.

Kanta J, Horský J, Kovářová H, Tilšer I, Korolenko TA, Bartoś F [1986]. Formation of granulomas in liver of silica-treated rats. Br J Exp Pathol 67(6):889-899. 
Karnik AB, Saiyed HN, Nigam SK [1990]. Humoral immunologic dysfunction in silicosis. Indian J Med Res [B] 92:440-442.

Katsnelson BA, Mokronosova KA [1979]. Non-fibrous mineral dusts and malignant tumors. J Occup Med 2l(1):15-20.

Kauppinen T, Partanen T, Degerth R, Ojajärvi A [1995]. Pancreatic cancer and occupational exposures. Epidemiology 6(5):498-502.

Kenny LC, Gussman RA [1997]. Characterization and modeling of a family of cyclone aerosol preseparators. J Aerosol Sci 28(4):677-688.

King EJ [1937]. Solubility of silica dusts. Nature 140:320.

King EJ, McGeorge M [1938]. The biochemistry of silicic acid: Parts V and VI: Biochem J 32:417-432.

Klein C, Hurlbut CS Jr. [1993]. Systematic mineralogy: Part IV: Silicates. In: Klein C, Hurlbut CS Jr., eds. Manual of mineralogy. 21st ed. New York: John Wiley \& Sons, Inc., pp. 440-531.

Kleinschmidt I, Churchyard G [1997]. Variation in incidences of tuberculosis in subgroups of South African gold miners. Occup Environ Med 54:636-641.

Klockars M, Koskela R-S, Järvinen E, Kolari PJ, Rossi A [1987]. Silica exposure and rheumatoid arthritis: A follow up study of granite workers, 1940-1981. Br Med J 294:997-1000.

Koeger AC, Alcaix D, Rozenberg S, Bourgeois P [1991]. Occupational exposure to silica and dermatopolymyositis: Three cases. Ann Med Interne 142(6): 409-413.

Koeger AC, Marre JP, Rozenberg S, Gutmann L, Bourgeois P [1992]. Autoimmune diseases after long-term occupational exposure to unusual sources of silica or silicone. Ann Med Interne 143(3):165-170.

Koeger AC, Lang T, Alcaix D, Milleron B, Rozenberg S, Chaibi P, Arnaud J, Mayaud C, Camus J-P, Bourgeois P [1995]. Silica-associated connective tissue disease: A study of 24 cases. Medicine 74(5):221-237.

Koeger AC, Alcaix D, Rozenberg S, Bourgeois $\mathrm{P}$ [1996]. Graves' disease after silica dust exposure [letter to the editor]. J Rheumatol 68(11):202.
Koskinen H, Tiilikainen A, Nordman H [1983]. Increased prevalence of HLA-Aw19 and of the phenogroup Aw19, B18 in advanced silicosis. Chest 83(6): 848-852.

Kreiss K, Zhen B [1996]. Risk of silicosis in a Colorado mining community. Am J Ind Med 30:529-539.

Kreiss K, Danilovs J, Newman LS [1989a]. Histocompatibility antigens in a population based silicosis series. Br J Ind Med 46:364-369.

Kreiss K, Greenberg LM, Kogut SJH, Lezotte DC, Irvin CG, Cherniack RM [1989b]. Hard-rock mining exposures affect smokers and nonsmokers differently: Results of a community prevalence study. Am Rev Respir Dis 139:1487-1493.

Kuchemann K, Holm R [1979]. Unusual silica granulomas of the skin with massive involvement of axillary lymph nodes. Pathol Res Pract 164(2):198-206.

Kurppa K, Gudbergsson H, Hannunkari I, Koskinen H, Hernberg S, Koskela R-S, Ahlman K [1986]. Lung cancer among silicotics in Finland. In: Goldsmith DF, Winn DM, Shy CM, eds. Silica, silicosis, and cancer: Controversy in occupational medicine. Cancer Research Monographs. Vol. 2. New York: Praeger, pp. 311-319.

Kusiak R, Liss GM, Gailitis MM [1993a]. Cor pulmonale and pneumoconiotic lung disease: An investigation using hospital discharge data. Am J Ind Med 24:161-173.

Kusiak R, Ritchie AC, Springer J, Muller J [1993b]. Mortality from stomach cancer in Ontario miners. Br J Ind Med 50:117-126.

Lacey JV, Laing TJ, Gillespie BW, Schottenfeld D [1997]. Epidemiology of scleroderma among women: Assessment of risk from exposure to silicone and silica [reply to letter to the editor]. J Rheumatol 24(9):18541855.

Lapp NL, Castranova V [1993]. How silicosis and coal workers' pneumoconiosis develop: A cellular assessment. Occup Med: State of the Art Rev 8(1):35-56.

Last JM [1988]. A dictionary of epidemiology. New York: Oxford University Press.

Laurell C-B, Eriksson S [1963]. The electrophoretic $\alpha_{1}$-globulin pattern of serum in $\alpha_{1}$-antitrypsin deficiency. Scand J Clin Lab Invest 15:132-140. 
Lawler AB, Mandel JS, Schuman LM, Lubin JH [1985]. A retrospective cohort mortality study of iron ore (hematite) miners in Minnesota. J Occup Med 27(7):507-517.

Lilienfeld DE, Stolley PD [1994]. Foundations of epidemiology. 3rd ed. New York: Oxford University Press.

Linch KD, Miller WE, Althouse RB, Groce DW, Hale JM [1998]. Surveillance of respirable crystalline silica dust using OSHA compliance data (1979-1995). Am J Ind Med 34:547-558.

Liu X, Keane MJ, Zhong B-Z, Ong T, Wallace WE [1996]. Micronucleus formation in V79 cells treated with respirable silica dispersed in medium and in simulated pulmonary surfactant. Mutat Res 361:89-94.

Liu X, Keane MJ, Harrison JC, Cilento EV, Ong T, Wallace WE [1998]. Phospholipid surfactant adsorption by respirable quartz and in vitro expression of cytotoxicity and DNA damage. Toxicol Lett 96,97:77-84.

Liu YC, Tomashefski J Jr., McMahon JT, Petrelli M [1991]. Mineral-associated hepatic injury: A report of seven cases with X-ray microanalysis. Hum Pathol 22:1120-1127.

Lorberau CD, Carsey TP, Fischbach TJ [1990]. Evaluation of direct-on-filter methods for the determination of respirable $\alpha$-quartz. Appl Occup Environ Hyg 5(1): 27-35.

Lucas AD, Salisbury SA [1992]. Industrial hygiene survey in a university art department. J Environ Pathol, Toxicol Oncol 11(1):21-27.

Madsen FA, Rose MC, Cee R [1995]. Review of quartz analytical methodologies: Present and future needs. Appl Occup Environ Hyg 10(12):991-1002.

Malik SK, Behera D, Awasthi GK, Singh JP [1985]. Pulmonary silicosis in emery polish workers. Indian J Chest Dis All Sci 27(2):116-121.

Masson C, Audran M, Pascaretti C, Chevailler A, Subra J-F, Tuchais E, Kahn M-F [1997]. Silica-associated systemic erythematosus lupus or mineral dust lupus? Lupus 6:1-3.

Masuda K [1981]. Chronic thyroiditis observed in patients with silicosis as an adjuvant disease of man (in Japanese). Shikoku Acta Med 37(1):119-129.
McCunney RJ, Godefroi R [1989]. Pulmonary alveolar proteinosis and cement dust: A case report. J Occup Med 31(3):233-237.

McCunney RJ, Russo PK, Doyle JR [1987]. Occupational illness in the arts. Am Fam Physician 36(5): $145-153$.

McDonald C [1995]. Silica, silicosis, and lung cancer: An epidemiological update. Appl Occup Environ Hyg 10(12):1056-1063.

McDonald JC [1989]. Silica, silicosis, and lung cancer [editorial]. Br J Ind Med 46:289-291.

McDonald JC [1996]. Silica and lung cancer. In: Castranova V, Vallyathan V, Wallace WE, eds. Silica and silica-induced lung diseases. Boca Raton, FL: CRC Press, Inc., pp. 383-396.

McDonald JC, Cherry N, McNamee R, Burgess G, Turner S [1995]. Preliminary analysis of proportional mortality in a cohort of British pottery workers exposed to crystalline silica. Scand J Work Environ Health 21(Suppl 2):63-65.

McDonald JC, Burgess GL, Turner S, Cherry NM [1997]. Cohort study of Staffordshire pottery workers: III. Lung cancer, radiographic changes, silica exposure and smoking habit. Ann Occup Hyg 41(Suppl 1): 412-414.

McLaughlin JK, Jing-Qiong C, Dosemeci M, Rong-An C, Rexing SH, Zhien W, Hearl FJ, McCawley MA, Blot WJ [1992]. A nested case-control study of lung cancer among silica exposed workers in China. Br J Ind Med 49:167-171.

Mehlhorn J [1984]. Progressive scleroderma without silicosis an occupational disease? Z Erkr Atmungsorgane 163:65-69.

Mehlhorn J, Gerlach C [1990]. The coincidence of silicosis and lupus erythematodes (in German). Z Erkr Atmungsorgane 175:38-41.

Mehlhorn J, Gerlach C, Ziegler V [1990a]. Occupationally dependent progressive systemic scleroderma due to a scouring powder containing quartz. Derm 38(6):180-184.

Mehlhorn J, Ziegler V, Keyn J, Vetter J [1990b]. Quartz crystals in the skin as cause of progressive systemic scleroderma. Z Gesamte Inn Med 45(6):149-154. 
Merlo F, Costantini M, Reggiardo G, Ceppi M, Puntoni R [1991]. Lung cancer risk among refractory brick workers exposed to crystalline silica: A retrospective cohort study. Epidemiology 2(4):299-305.

Meyniel D, Mayaud C, Chatelet F, Cohen-Solal A, R Pieron [1981]. Cortico-sensitive asphyxiating pneumopathy found with disseminated acute erythematous lupus in a patient suffering from silicosis (in French). La Revue de Med Interne 2(4):431-432.

Miller AB, Scarpelli D, Weiss NS [1987]. Report of the scientific panel on "mortality from cancer among Ontario gold miners, 1955-1977." Appendix C of the Industrial Disease Standards Panel report to the Workers' Compensation Board of the Ontario gold mining industry. Toronto, Ontario, Canada: Ministry of Labour, pp. 64-86.

Miller BG, Hagen S, Love RG, Soutar CA, Cowie HA, Kidd MW, Robertson A [1998]. Risks of silicosis in coalworkers exposed to unusual concentrations of respirable quartz. Occup Environ Med 55:52-58.

Miranda RN, McMillan PN, Pricolo VE, Finkelstein SD [1996]. Peritoneal silicosis. Arch Pathol Lab Med 120:300-302.

Morgan WKC [1978]. Industrial bronchitis. Br J Ind Med 35:285-291.

Morgan WKC, Reger RB [1995]. Occupational lung cancer. In: Morgan WKC, Seaton A, eds. Occupational lung diseases. 3rd ed. Philadelphia, PA: W.B. Saunders Co., pp. 624-642.

Mossman BT, Churg A [1998]. Mechanisms in the pathogenesis of asbestosis and silicosis. Am J Respir Crit Care Med 157:1666-1680.

Mowry RG, Sams M Jr., Caulfield JB [1991]. A rare entity or rarely diagnosed? Report of two cases with review of the literature. Arch Dermatol 127:692-694.

MSHA [1994]. Infrared determination of quartz in respirable coal mine dust: Method P-7. Pittsburgh, PA: U.S. Department of Labor, Mine Safety and Health Administration.

MSHA [1999]. X-ray diffraction determination of quartz and cristobalite in respirable mine dust: Method P-2. Pittsburgh, PA: U.S. Department of Labor, Mine Safety and Health Administration.
Muhle H, Takenaka S, Mohr U, Dasenbrock C, Mermelstein R [1989]. Lung tumor induction upon long-term low-level inhalation of crystalline silica. Am J Ind Med 15(3):343-346.

Muir DCF [1991]. Correction in cumulative risk in silicosis exposure assessment [letter to the editor]. Am J Ind Med 19:555.

Muir DCF, Shannon HS, Julian JA, Verma DK, Sebestyen A, Bernholz CD [1989a]. Silica exposure and silicosis among Ontario hardrock miners: I. Methodology. Am J Ind Med 16:5-11.

Muir DCF, Shannon HS, Julian JA, Verma DK, Sebestyen A, Bernholz CD [1989b]. Silica exposure and silicosis among Ontario hardrock miners: III. Analysis and risk estimates. Am J Ind Med 16:29-43.

Muller J, Wheeler WC, Gentleman JF, Suranyi G, Kusiak RA [1983]. Study of mortality of Ontario miners: 1955-1977. Part I. Toronto, Ontario, Canada: Ontario Ministry of Labour, Ontario Workers' Compensation Board, Atomic Energy Control Board of Canada, NTIS Document No. DE88703584

Mulrow CD [1994]. Rationale for systematic reviews. Br Med J 309:597-599.

Mur J-M, Meyer-Bisch C, Pham QT, Massin N, Moulin JJ, Cavelier C, Sadoul P [1987]. Risk of lung cancer among iron ore miners: A proportional mortality study of 1,075 deceased miners in Lorraine, France. J Occup Med 29(9):762-788.

Muramatsu K, Yamamoto T, Hasegawa A, et al. [1989]. A case of autoimmune hemolytic anemia associated with silicosis. Jpn J Chest Dis 48(1):45-50.

Murphy M, Wiehe P, Barnes L [1997]. Silica granuloma: Another cause of tennis elbow [letter to the editor]. Br J Dermatol 137:467-484.

Murray J, Reid G, Kielkowski D, de Beer M [1993]. Cor pulmonale and silicosis: A necropsy based case-control study. Br J Ind Med 50:544-548.

Nagalakshmi R, Nath J, Ong T, Whong W-Z [1995]. Silica-induced micronuclei and chromosomal aberrations in Chinese hamster lung (V79) and human lung (Hel 299) cells. Mutat Res 335:27-33.

Navrotsky A [1994]. Thermochemistry of crystalline and amorphous silica. In: Heaney PJ, Prewitt CT, Gibbs GV, eds. Reviews in mineralogy. Vol. 29. Silica: 
Physical behavior, geochemistry, and materials applications. Washington, DC: Mineralogical Society of America, pp. 309-329.

Nemery B, Van Kerckhoven W, Verbeken EK, Dinsdale D, Demedts M [1993]. An unexpected risk of pneumoconiosis in breweries. In: Hurych J, Lesage M, David A, eds. Proceedings of the Eighth International Conference on Occupational Lung Diseases, September 14-17, 1992. Prague, Czechoslovakia: Czech Medical Society, pp. 658-663.

Neuberger M, Kundi M [1990]. Occupational dust exposure and cancer mortality-results of a prospective cohort study. In: Simonato L, Fletcher AC, Saracci R, Thomas TL, eds. Occupational exposure to silica and cancer risk. Lyon, France: International Agency for Research on Cancer, Scientific Publications No. 97:65-73.

Neyer U, Woss E, Neuweiler J [1994]. Case report: Wegener's granulomatosis associated with silicosis. Nephrol Dial Transplant 9(5):559-561.

Ng TP, Chan SL [1991]. Factors associated with massive fibrosis in silicosis. Thorax 46(4):229-232.

Ng TP, Chan SL [1994]. Quantitative relations between silica exposure and development of radiological small opacities in granite workers. Ann Occup Hyg 38(Suppl 1):857-863.

Ng TP, Chan SL, Lam KP [1987]. Radiological progression and lung function in silicosis: A ten year follow up study. Br Med J 295:164-168.

Ng TP, Ng YL, Lee HS, Chia KS, Ong HY [1992a]. A study of silica nephrotoxicity in exposed silicotic and non-silicotic workers. Br J Ind Med 49:35-37.

Ng TP, Phoon WH, Lee HS, Ng YL, Tan KT [1992b]. An epidemiological survey of respiratory morbidity among granite quarry workers in Singapore: Chronic bronchitis and lung function impairment. Ann Acad Med Singapore 21(3):312-317.

Ng TP, Lee HS, Phoon WH [1993]. Further evidence of human silica nephrotoxicity in occupationally exposed workers. Br J Ind Med 50:907-912.

NIOSH [1974]. Criteria for a recommended standard: Occupational exposure to crystalline silica. Cincinnati, OH: U.S. Department of Health, Education, and Welfare, Health Services and Mental Health Administration, National Institute for Occupational Safety and Health, DHEW (NIOSH) Publication No. 75-120.
NIOSH [1979a]. Crystalline silica. In: Hutchison M, Kusnetz S, eds. A guide to the work-relatedness of disease. Rev. ed. Cincinnati, OH: U.S. Department of Health, Education, and Welfare, Public Health Service, Center for Disease Control, National Institute for Occupational Safety and Health, DHEW (NIOSH) Publication No. 79-116, pp. 155-167.

NIOSH [1979b]. Free silica (quartz, cristobalite, tridymite) in airborne dust: Method P\&CAM 259. In: NIOSH manual of analytical methods. 2nd ed., Vol. 5. Cincinnati, OH: U.S. Department of Health, Education, and Welfare, Public Health Service, Centers for Disease Control, National Institute for Occupational Safety and Health, DHEW (NIOSH) Publication No. 79-41.

NIOSH [1983a]. Review of the literature on crystalline silica. Cincinnati, OH: U.S. Department of Health and Human Services, Public Health Service, Centers for Disease Control, National Institute for Occupational Safety and Health, NTIS PB83-238-733.

NIOSH [1983b]. National occupational exposure survey (NOES), 1981-83. Cincinnati, OH: U.S. Department of Health and Human Services, Public Health Service, Centers for Disease Control, National Institute for Occupational Safety and Health, Division of Surveillance, Hazard Evaluations, and Field Studies, Surveillance Branch. Unpublished data.

NIOSH [1988]. National occupational exposure survey field guidelines. Vol. I. Seta JA, Sundin DS, Pedersen DH, eds. Cincinnati, OH: U.S. Department of Health and Human Services, Public Health Service, Centers for Disease Control, National Institute for Occupational Safety and Health, DHHS (NIOSH) Publication No. 88-106.

NIOSH [1991]. Work-related lung disease surveillance report. Cincinnati, OH: U.S. Department of Health and Human Services, Public Health Service, Centers for Disease Control, National Institute for Occupational Safety and Health, DHHS (NIOSH) Publication No. 91-113, Table 23, p. 38.

NIOSH [1992a]. NIOSH alert: Request for assistance in preventing silicosis and deaths from sandblasting. Cincinnati, OH: U.S. Department of Health and Human Services, Public Health Service, Centers for Disease Control, National Institute for Occupational Safety and Health, DHHS (NIOSH) Publication No. 92-102.

NIOSH [1992b]. NIOSH alert: Request for assistance in preventing silicosis and deaths in rock drillers. Cincinnati, OH: U.S. Department of Health and Human 
Services, Public Health Service, Centers for Disease Control, National Institute for Occupational Safety and Health, DHHS (NIOSH) Publication No. 92-107.

NIOSH [1994a]. Silica, crystalline by IR: Method 7602. In: NIOSH manual of analytical methods, 4th rev. ed. Cincinnati, OH: U.S. Department of Health and Human Services, Public Health Service, Centers for Disease Control and Prevention, National Institute for Occupational Safety and Health, DHHS (NIOSH) Publication No. 94-113.

NIOSH [1994b]. Silica, crystalline by vis: Method 7601. In: NIOSH manual of analytical methods, 4th rev. ed. Cincinnati, OH: U.S. Department of Health and Human Services, Public Health Service, Centers for Disease Control and Prevention, National Institute for Occupational Safety and Health, DHHS (NIOSH) Publication No. 94-113.

NIOSH [1994c]. Silica, crystalline in coal mine dust, by IR: Method 7603. In: NIOSH manual of analytical methods, 4th rev. ed. Cincinnati, OH: U.S. Department of Health and Human Services, Public Health Service, Centers for Disease Control and Prevention, National Institute for Occupational Safety and Health, DHHS (NIOSH) Publication No. 94-113.

NIOSH [1994d]. Work-related lung disease surveillance report. Cincinnati, OH: U.S. Department of Health and Human Services, Public Health Service, Centers for Disease Control and Prevention, National Institute for Occupational Safety and Health, Division of Respiratory Disease Studies, DHHS (NIOSH) Publication No. 94-120.

NIOSH [1995a]. Criteria for a recommended standard: Occupational exposure to respirable coal mine dust. Cincinnati, OH: U.S. Department of Health and Human Services, Public Health Service, Centers for Disease Control and Prevention, National Institute for Occupational Safety and Health, DHHS (NIOSH) Publication No. 95-106.

NIOSH [1995b]. Guidelines for air sampling and analytical method development and evaluation. Cincinnati, Ohio: U.S. Department of Health and Human Services, Public Health Service, Centers for Disease Control and Prevention, National Institute for Occupational Safety and Health, DHHS (NIOSH) Publication No. 95-117.

NIOSH [1996a]. Work-related lung disease surveillance report. Cincinnati, OH: U.S. Department of Health and Human Services, Public Health Service, Centers for Disease Control and Prevention, National Institute for
Occupational Safety and Health, DHHS (NIOSH) Publication No. 96-134.

NIOSH [1996b]. NIOSH alert: Request for assistance in preventing silicosis and deaths in construction workers. Cincinnati, OH: U.S. Department of Health and Human Services, Public Health Service, Centers for Disease Control and Prevention, National Institute for Occupational Safety and Health, DHHS (NIOSH) Publication No. 96-112.

NIOSH [1996c]. NIOSH technical report: Results from the National Occupational Health Survey of Mining (NOHSM). Greskevitch MF, Bajpayee SS, Hale JM, Groce DW, Hearl FJ, eds. Cincinnati, OH: U.S. Department of Health and Human Services, Public Health Service, Centers for Disease Control and Prevention, National Institute for Occupational Safety and Health, DHHS (NIOSH) Publication No. 96-136.

NIOSH [1998]. Silica, crystalline, by XRD: Method 7500. In: NIOSH manual of analytical methods, 4 th rev. ed., 2nd suppl. Cincinnati, OH: U.S. Department of Health and Human Services, Public Health Service, Centers for Disease Control and Prevention, National Institute for Occupational Safety and Health, DHHS (NIOSH) Publication No. 98-119.

NIOSH [2000]. Worker Health Chartbook, 2000. Cincinnati, OH: U.S. Department of Health and Human Services, Public Health Service, Centers for Disease Control and Prevention, National Institute for Occupational Safety and Health, DHHS (NIOSH) Publication No. 2000-127.

NIOSH, BOM [1983]. Collaborative tests of two methods for determining free silica in airborne dust. Cincinnati, Ohio: U.S. Department of Health and Human Services, Public Health Service, Centers for Disease Control, National Institute for Occupational Safety and Health; U.S. Department of the Interior, Bureau of Mines, DHHS (NIOSH) Publication No. 83-124.

Nuyts GD, Van Vlem E, De Vos A, Daelemans RA, Rorive G, Elseviers MM, Schurgers M, Segaert M, D'Haese PC, De Broe ME [1995]. Wegener granulomatosis is associated to exposure to silicon compounds: A case-control study. Nephrol Dial Transplant 10:11621165.

Okrouhlílik B, Hykeš P [1983]. Symptomatic hepatic porphyria in workers exposed to free silicon dioxide [medical proceedings]. Sb Lek 85(6):170-172. 
OSHA [1996]. Quartz and cristobalite in workplace atmospheres: Method ID-142. Salt Lake City, UT: U.S. Department of Labor, Occupational Safety and Health Administration.

Oshimura M, Hesterberg TW, Tsutsui T, Barrett JC [1984]. Correlation of asbestos-induced cytogenetic effects with cell transformation of Syrian hamster embryo cells in culture. Cancer Res 44:5017-5022.

Osorio AM, Thun MJ, Novak RF, Van Cura J, Avner ED [1987]. Silica and glomerulonephritis: Case report and review of the literature. Am J Kidney Dis 9(3):224-230.

Oswald P, Filippi de la Palavesa MM, Uhl G, Ghnassia JP, Doffoel M, Dietemann JL [1995]. Silicose hépatosplénique (in French). J Radiol 76(8):513-516.

Otsuki T, Sakaguchi H, Tomokuni A, Aikoh T, Matsuki T, Kawakami Y, Kusaka M, Ueki H, Kita S, Ueki A [1998]. Soluble Fas mRNA is dominantly expressed in cases with silicosis. Immunology 94:258-262.

Owens MW, Kinasewitz GT, Gonzalez E [1988]. Case report: Sandblaster's lung with mycobacterial infection. Am J Med Sci 295(6):554-557.

Oxman AD, Muir DCF, Shannon HS, Stock SR, Hnizdo E, Lange HJ [1993]. Occupational dust exposure and chronic obstructive pulmonary disease: A systematic overview of the evidence. Am Rev Respir Dis 148:3848.

Özoran K, Uçan H, Tutkak H, Caner N, Yücel M [1997]. Systemic lupus erythematosus arising in a patient with chronic silicosis [letter to the editor]. Rheumatol Int 16:217-218.

Pairon JC, Jaurand MC, Kheuang L, Janson X, Brochard P, Bignon J [1990]. Sister chromatid exchanges in human lymphocytes treated with silica. Br J Ind Med 47:110-115.

Pan G, Takahashi K, Feng Y, Liu L, Liu T, Zhang S, Liu N, Okubo T, Goldsmith DF [1999]. Nested case-control study of esophageal cancer in relation to occupational exposure to silica and other dusts. Am J Ind Med 35: 272-280.

Parent M-É, Siemiatycki J, Fritschi L [1998]. Occupational exposures and gastric cancer. Epidemiology $9(1): 48-55$.
Parker JE [1994]. Silicosis. In: Rakel RE, ed. Conn's current therapy. Philadelphia, PA: W.B. Saunders, pp. 207-210.

Parker JE, Wagner GR [1998]. Silicosis. In: Stellman $\mathrm{JM}$, ed. Encyclopaedia of occupational health and safety. 4th ed. Geneva, Switzerland: International Labour Office, pp. 10.43-10.46.

Parkes WR, ed. [1982]. Occupational lung disorders. 2nd ed. London: Butterworths, pp. 222-237.

Parkes WR, ed. [1994]. Chronic bronchitis, airflow obstruction and emphysema. In: Occupational lung disorders. 3rd ed. London: Butterworth Heinemann, Ltd., pp. 222-237.

Partanen T, Pukkala E, Vainio H, Kurppa K, Koskinen H [1994]. Increased incidence of lung and skin cancer in Finnish silicotic patients. J Occup Med 36(6):616-622.

Pelmear PL, Roos JO, Maehle WM [1992]. Occupationally-induced scleroderma. J Occup Med 34(1):2025 .

Perez Perez AJ, Sobrado J, Cigarran S, Courel M, Gonzalez L, Fernandez R, Villanueva JP [1986]. Renal vasculitis, diffuse pulmonary hemorrhage and silicosis: An analysis of two cases. Med Clin (Barcelona) 87(20): $858-860$

Peters JM [1986]. Silicosis. In: Merchant JA, Boehlecke BA, Taylor G, Pickett-Harner M, eds. Occupational respiratory diseases. Cincinnati, OH: U.S. Department of Health and Human Services, Public Health Service, Centers for Disease Control, National Institute for Occupational Safety and Health, DHHS (NIOSH) Publication No. 86-102, pp. 219-237.

Petersen PE, Henmar P [1988]. Oral conditions among workers in the Danish granite industry. Scand J Work Environ Health 14:328-331.

Pevnitskiy LA, Fedrunova VS, Nazarova EK, Levin AI, Garkavenko OS, Erisman FF [1978]. Some immunogenetic indexes in silicosis. Gig Trud Prof Zabol (5):5254 .

Pike S [1992]. Art and artists. In: Sullivan JB Jr., Krieger GR, eds. Hazardous materials toxicology. Clinical principles of environmental health. Baltimore, MD: Williams and Wilkins, pp. 690-696. 
Pouthier D, Duhoux P, Van Damme B [1991]. Pulmonary silicosis and glomerular nephropathy: A case. Nephrologie 12(1):8-11.

Price EW, Henderson WJ [1981]. Endemic elephantiasis of the lower legs in the United Cameroon Republic. Trop Geogr Med 33:23-29.

Price-Jones MJ, Gubbings G, Chamberlain M [1980]. The genetic effects of crocidolite asbestos: Comparison of chromosome abnormalities and sister-chromatid exchanges. Mutat Res 79:331-336.

Puntoni R, Goldsmith DG, Valerio F, Vercelli M, Bonassi S, Di Giorgio F, Ceppi M, Stagnaro E, Filiberti R, Santi L, Merlo F [1988]. A cohort study of workers employed in a refractory brick plant. Tumori $74: 27-33$.

Rabovsky J [1995]. Biogenic amorphous silica. Scand J Work Environ Health 21(Suppl 2):108-110.

Radford EP, St. Clair Renard KG [1984]. Lung cancer in Swedish iron miners exposed to low doses of radon daughters. New Engl J Med 310(23):1485-1494.

Rafnsson V, Gunnarsdóttir H [1997]. Lung cancer incidence among an Icelandic cohort exposed to diatomaceous earth and cristobalite. Scand J Work Environ Health 23:187-192.

Rafnsson V, Ingimarsson O, Hjalmarsson I, Gunnarsdóttir H [1998]. Association between exposure to crystalline silica and risk of sarcoidosis. Occup Environ Med 55:657-660.

Rastogi SK, Gupta BN, Chandra H, Mathur N, Mahendra PN, Husain T [1991]. A study of the prevalence of respiratory morbidity among agate workers. Int Arch Occup Environ Health 63:21-26.

Redmond CK, Weiand HS, Rockette HE, Sass R, Weinberg G [1981]. Long-term mortality experience of steelworkers. Cincinnati, OH: U.S. Department of Health and Human Services, Public Health Service, Centers for Disease Control, National Institute for Occupational Safety and Health, NIOSH Publication No. 81-120.

Rice FL, Stayner LT [1995]. Assessment of silicosis risk for occupational exposure to crystalline silica. Scand J Work Environ Health 21(Suppl 2):87-90.

Rice CH, Harris RL Jr., Checkoway H, Symons MJ [1986]. Dose-response relationships for silicosis from a case-control study of North Carolina dusty trades workers. In: Goldsmith DF, Winn DM, Shy CM, eds. Silica, silicosis, and cancer: Controversy in occupational medicine, Cancer Research Monographs. Vol. 2. New York: Praeger, pp. 77-86.

Rispal P, Wen L, De Precigout V, Aparicio M [1991]. Nephropathy with silica in a dental technician. Presse Med 20(4):176.

Robbins SL [1974]. Pathologic basis of disease. Philadelphia, PA: W.B. Saunders Co., pp. 239-240.

Rodriguez J, Delgado O, Ibarra E, Valdivieso J [1985]. Pneumoconiosis in kaolin workers. Bol Med Trab 1(2): 99-109.

Roeslin N, Lassabe-Roth C, Morand G, Batzenschlager A [1980]. La silico-protéinose aiguë. Arch Mal Prof 41(1):15-18.

Roperto F, Troncone A, Tranquillo A, Galati P [1995]. Extrapulmonary silicosis in two water buffaloes. J Comp Pathol 112:97-103.

Rosenman KD, Zhu Z [1995]. Pneumoconiosis and associated medical conditions. Am J Ind Med 27:107-113.

Rosenman KD, Stanbury MJ, Reilly MJ [1995]. Mortality among persons with silicosis reported to disease surveillance systems in Michigan and New Jersey in the United States. Scand J Work Environ Health 21(Suppl 2):73-76.

Rosenman KD, Reilly MJ, Rice C, Hertzberg V, Tseng C-Y, Anderson HA [1996]. Silicosis among foundry workers: Implication for the need to revise the OSHA standard. Am J Epidemiol 144(9):890-900.

Rosenstock L [1994]. Introduction: The chest radiograph and pulmonary function testing. In: Rosenstock L, Cullen MR, eds. Textbook of clinical, occupational and environmental medicine. Philadelphia, PA: W.B. Saunders Co., pp. 194-197.

Saffiotti U, Ahmed N [1995]. Neoplastic transformation by quartz in the BALB/3T3/A31-1-1 cell line and the effects of associated minerals. Teratog Carcinog Mutagen 15(6):339-356.

Saffiotti U, Daniel LN, Mao Y, Williams AO, Kaighn ME, Ahmed N, Knapton AD [1993]. Biological studies on the carcinogenic mechanisms of quartz. In: Guthrie GD Jr., Mossman BT, eds. Reviews in mineralogy: 
Health effects of mineral dusts. Vol. 28. Washington, DC: Mineralogical Society of America, pp. 523-544.

Saffiotti U, Daniel LN, Mao Y, Shi X, Williams AO, Kaighn ME [1994]. Mechanisms of carcinogenesis by crystalline silica in relation to oxygen radicals. Environ Health Perspect 102(Suppl 10):159-163.

Saffiotti U, Williams AO, Daniel LN, Kaighn ME, Mao Y, Shi X [1996]. Carcinogenesis by crystalline silica: Animal, cellular, and molecular studies. In: Castranova V, Vallyathan V, Wallace WE, eds. Silica and silica-induced lung diseases. Boca Raton, FL: CRC Press, Inc., pp. 345-381.

Saita G, Zavaglia O [1951]. Kidney function in silicotics. Med Lav 42(2):41-48.

Samet JM, Young RA, Morgan MV, Humble CG, Epler GR, McLoud TC [1984]. Prevalence survey of respiratory abnormalities in New Mexico uranium miners. Health Phys 46(2):361-370.

Sanchez-Roman J, Wichmann I, Salaberri J, Varela JM, Nuñez-Roldan A [1993]. Multiple clinical and biological autoimmune manifestations in 50 workers after occupational exposure to silica. Ann Rheum Dis 52:534538.

Schulte PA [1995]. Opportunities for the development and use of biomarkers. Toxicol Lett 77(1-3):25-29.

Seaton A [1995]. Silicosis. In: Morgan WKC, Seaton A, eds. Occupational lung diseases. 3rd ed. Philadelphia, PA: W.B. Saunders Co., pp. 222-267.

Seitz B, Gaucher P, Reverdy C [1982]. Case of silicosis in a cleaning and dying employee. Arch Mal Prof 43(6):477-478.

Seixas NS, Heyer NJ, Welp EAE, Checkoway H [1997]. Quantification of historical dust exposures in the diatomaceous earth industry. Ann Occup Hyg 41(5): 591-604.

Shannon H, Heller JG, Pron G, Gallina P, MacRae J [1987]. Report of the Special Panel on the Ontario gold mining industry. Appendix A of Industrial Disease Standards Panel report to the Workers' Compensation Board of the Ontario gold mining industry. Toronto, Ontario, Canada: Ministry of Labour, pp. 11-55.

Sherson D, Jørgensen F [1989]. Rapidly progressive crescenteric glomerulonephritis in a sandblaster with silicosis. Br J Ind Med 46:675-676.
Sherson D, Lander F [1990]. Morbidity of pulmonary tuberculosis among silicotic and nonsilicotic foundry workers in Denmark. J Occup Med 32(2):110-113.

Shi X, Mao Y, Daniel LN, Saffiotti U, Dalal NS, Vallyathan V [1994]. Silica radical-induced DNA damage and lipid peroxidation. Environ Health Persp 102(Suppl 10):149-154.

Shi X, Castranova V, Halliwell B, Vallyathan V [1998]. Reactive oxygen species and silica-induced carcinogenesis. J Toxicol Environ Health, Part B, 1:181-197.

Shulman SA, Groff JH, Abel MT [1992]. Performance of laboratories measuring silica in the Proficiency Analytical Testing Program. Am Ind Hyg Assoc J 53(1): 49-56.

Siebels M, Schulz V, Andrassy K [1995]. Systemic lupus erythematodes and silicosis (in German). Dtsch Med Wochenschr 120(7):214-218.

Siemiatycki J, Wacholder S, Dewar R, Wald L, Bégin D, Richardson L, Rosenman K, Gérin M [1988]. Smoking and degree of occupational exposure: Are internal analyses in cohort studies likely to be confounded by smoking status? Am J Ind Med 13:59-69.

Silicosis and Silicate Disease Committee [1988]. Diseases associated with exposure to silica and nonfibrous silicate minerals. Arch Pathol Lab Med 112:673-720.

Silverstein M, Maizlish N, Park R, Silverstein B, Brodsky L, Mirer F [1986]. Mortality among ferrous foundry workers. Am J Ind Med 10(1):27-43.

Slavin RE, Swedo JL, Brandes D, Gonzalez-Vitale JC, Osornio-Vargas A [1985]. Extrapulmonary silicosis: A clinical, morphologic, and ultrastructural study. Hum Pathol a clinicopathologic quarterly 16(4):393-412.

Sluis-Cremer GK, Maier G [1984]. Notes and miscellanea: HLA antigens of the A and $B$ locus in relation to the development of silicosis. Br J Ind Med 41:417-418.

Sluis-Cremer GK, Walters LG, Sichel HS [1967]. Chronic bronchitis in miners and non-miners: An epidemiological survey of a community in the gold-mining area in the Transvaal. Br J Ind Med 24:1-12.

Sluis-Cremer GK, Hessel PA, Hnizdo E, Churchill AR, Zeiss EA [1985]. Silica, silicosis, and progressive systemic sclerosis. Br J Ind Med 42:838-843. 
Sluis-Cremer GK, Hessel PA, Hnizdo E, Churchill AR [1986]. Relationship between silicosis and rheumatoid arthritis. Thorax 41:596-601.

Smith AH, Lopipero PA, Barroga VR [1995]. Metaanalysis of studies of lung cancer among silicotics. Epidemiology 6(6):617-624.

Smith DK [1997]. Evaluation of the detectability and quantification of respirable crystalline silica by X-ray powder diffraction methods. Powder Diffraction 12(4): 200-227.

Snider GL [1989]. 1. Changes in COPD occurrence: Chronic obstructive pulmonary disease; a definition and implications of structural determinants of airflow obstruction for epidemiology. Am Rev Respir Dis 140(3 Part 2):S3-S8.

Sobti RC, Bhardwaj DK [1991]. Cytogenetic damage and occupational exposure: I. Exposure to stone dust. Environ Res 56:25-30.

Sparks PJ, Wegman DH [1980]. Cause of death among jewelry workers. J Occup Med 22(11):733-736.

Spiethoff A, Wesch H, Wegener K, Klimisch H-J [1992]. The effects of thorotrast and quartz on the induction of lung tumors in rats. Health Phys 63(1):101-110.

Steenland K [1997]. E-mail message on March 5, 1997, from Kyle Steenland to Faye L. Rice, Education and Information Division, National Institute for Occupational Safety and Health, Centers for Disease Control and Prevention, Public Health Service, U.S. Department of Health and Human Services.

Steenland K) [1998]. E-mail message on October 30, 1998, from Kyle Steenland to Faye L. Rice, Education and Information Division, National Institute for Occupational Safety and Health, Centers for Disease Control and Prevention, Public Health Service, U.S. Department of Health and Human Services.

Steenland K, Beaumont J [1986]. A proportionate mortality study of granite cutters. Am J Ind Med 9:189-201.

Steenland K, Brown D [1995a]. Silicosis among gold miners: Exposure-response analyses and risk assessment. Am J Public Health 85(10):1372-1377.

Steenland K, Brown D [1995b]. Mortality study of gold miners exposed to silica and nonasbestiform amphibole minerals: An update with 14 more years of follow-up. Am J Ind Med 27:217-229.
Steenland K, Goldsmith DF [1995]. Silica exposure and autoimmune diseases. Am J Ind Med 28:603-608.

Steenland K, Stayner L [1997]. Silica, asbestos, manmade mineral fibers, and cancer. Cancer Causes Control 8:491-503.

Steenland NK, Thun MJ, Ferguson CW, Port FK [1990]. Occupational and other exposures associated with male end-stage renal disease: A case/control study. Am J Public Health 80(2):153-159.

Steenland K, Nowlin S, Ryan B, Adams S [1992]. Use of multiple-cause mortality data in epidemiologic analyses: US rate and proportion files developed by the National Institute for Occupational Safety and Health and the National Cancer Institute. Am J Epidemiol 136(7): 855-862.

Stubbs HA, Harris J, Spear RC [1984]. A proportionate mortality analysis of California agricultural workers, 1978-1979. Am J Ind Med 6:305-320.

Stulbarg MS, Zimmerman L [1996]. Chronic obstructive pulmonary disease. In: Harber P, Schenker MB, Balmes JR, eds. Occupational and environmental respiratory disease. St. Louis, MO: Mosby, pp. 228-242.

Suratt PM, Winn WC, Brody AR, Bolton WK, Giles RD [1977]. Acute silicosis in tombstone sandblasters. Am Rev Respir Dis 115:521-529.

Suskovic T, Mose J, Vucicevic Z [1990]. Pulmonary silicosis complicated by systemic vasculitis. Plucne Bolesti 42(1-2):77-79.

Sweeney TD, Brain JD [1996]. Lavagable biomarkers of exposure to fibrogenic dusts. In: Castranova V, Vallyathan V, Wallace WE eds. Silica and silica-induced lung diseases. Boca Raton, FL: CRC Press, Inc., pp. 197207.

Talini D, Paggiaro PL, Falaschi F, Battolla L, Carrara M, Petrozzino M, Begliomini E, Bartolozzi C, Giuntini C [1995]. Chest radiography and high resolution computed tomography in the evaluation of workers exposed to silica dust: Relation with functional findings. Occup Environ Med 52:262-267.

Talvitie NA [1951]. Determination of quartz in the presence of silicates using phosphoric acid. Anal Chem 23:623-626.

Talvitie NA [1964]. Determination of free silica: Gravimetric and spectrophotometric procedures applicable to 
air-borne and settled dusts. Am Ind Hyg Assoc J 25: $169-178$.

Talvitie NA, Hyslop F [1958]. Colorimetric determination of siliceous atmospheric contaminants. Am Ind Hyg Assoc J 19:54-58.

Theriault GP, Burgess WA, DiBerardinis LJ, Peters JM [1974a]. Dust exposure in the Vermont granite sheds. Arch Environ Health 28:12-17.

Theriault GP, Peters JM, Fine LJ [1974b]. Pulmonary function in granite shed workers of Vermont. Arch Environ Health 28:18-22.

Thomas TL [1990]. Lung cancer mortality among pottery workers in the United States. In: Simonato L, Fletcher AC, Saracci R, Thomas TL, eds. Occupational exposure to silica and cancer risk. Lyon, France: International Agency for Research on Cancer, pp. 75-81.

Thomas TL, Stewart PA [1987]. Mortality from lung cancer and respiratory disease among pottery workers exposed to silica and talc. Am J Epidemiol 125(1):3543.

Thoreux PH, Delaval PH, Leprince V, Ramee MP, Bouget J, Chretien J [1990]. Pulmonary silicosis due to working with exotic woods. La Presse Med 19(21): 1011.

Tockman MS, Comstock GW [1989]. Respiratory risk factors and mortality: Longitudinal studies in Washington County, Maryland. Am Rev Respir Dis 140:S56S63.

Tokumaru Y, Hirayama K, Kita K, Kawamura M, Katayama K [1990]. Two cases of ataxic sensory neuropathy associated with silicosis. Clin Neurol 30:933938.

Tschopp JM, Rossini MJ, Richon CA, Letovanec N, Joris F, Frey JG, Kaelin RM [1992]. Retroperitoneal silicosis mimicking pancreatic carcinoma in an Alpine miner with chronic lung silicosis. Thorax 47:480-481.

Tsuda T, Babazono A, Yamamoto E, Mino Y, Matsuoka $\mathrm{H}$ [1997]. A meta-analysis on the relationship between pneumoconiosis and lung cancer. J Occup Health 39: 285-294.

Vallyathan V, Castranova V, Pack D, Leonard S, Shumaker J, Hubbs AF, Shoemaker DA, Ramsey DM, Pretty JR, McLaurin JL, Khan A, Teass A [1995]. Freshly fractured quartz inhalation leads to enhanced lung injury and inflammation. Am J Respir Crit Care Med 152:1003-1009.

NN, Frash VN, Kogan FM [1985]. Use of the micronucleus test as a rapid method of detecting the potential carcinogenicity of asbestos-containing and other mineral fibers. Gig Trud Prof Zabol (6):45-48.

Van den Heever DJ [1994]. Quantification of bypass leakage in two different filter cassettes during welding fume sampling. Am Ind Hyg Assoc J 55(10):966-969.

Verma DK, Sebestyen A, Julian JA, Muir DCF, Schmidt H, Bernholz CD, Shannon HS [1989]. Silica exposure and silicosis among Ontario hardrock miners: II. Exposure estimates. Am J Ind Med 16:13-28.

Vigliani EC, Mottura G [1948]. Diatomaceous earth silicosis. Br J Ind Med 5:148-160.

Vigliani EC, Pernis B [1958]. Immunological factors in the pathogenesis of the hyaline tissue of silicosis. Br J Ind Med 15:8-14.

Virta RL [1993]. Crystalline silica: What it is - and isn't. Minerals Today, October:12-16.

Wagner GR [1994]. Mineral dusts. In: Rosenstock L, Cullen MR, eds. Textbook of clinical occupational and environmental medicine. Philadelphia, PA: W.B. Saunders Co., pp. 825-837.

Wagner GR [1995]. The inexcusable persistence of silicosis [editorial]. Am J Public Health 85(10):1346-1347.

Wagner GR [1997]. Occupational medicine: Asbestosis and silicosis. Lancet 349:1311-1315.

Watanabe S, Shirakami A, Takeichi T, Ohara T, Saito S [1987]. Alterations in lymphocyte subsets and serum immunoglobulin levels in patients with silicosis. J Clin Lab Immunol 23:45-51.

Weber SL, Banks DE [1994]. Silicosis. In: Rosenstock L, Cullen MR, eds. Textbook of clinical occupational and environmental medicine. Philadelphia, PA: W.B. Saunders Co., pp. 264-274.

Webster DL [1982]. Steel production. In: Cralley LV, Cralley LJ, eds. Industrial Hygiene Aspects of Plant Operations, Vol. 1. Process flows. Macmillian Publishing Co., Inc., pp. 457-486. 
Weill H, McDonald JC [1996]. Exposure to crystalline silica and risk of lung cancer: The epidemiological evidence. Thorax 51:97-102.

Weill H, Jones RN, Parkes WR [1994]. Silicosis and related diseases. In: Parkes WR, ed. Occupational lung disorders. 3rd ed. London: Butterworth-Heinemann Ltd., pp. 285-339.

Weissman DN, Ma JKH, Rojanasakul Y, Hubbs AF [1996]. Immune dysfunction in silicosis: A hypothesis. Appl Occup Environ Hyg 11(7):962-965.

Westerholm P [1980]. Silicosis: Observations on a case register. Scand J Work Environ Health 6(Suppl 2):5-86.

Westerholm P, Ahlmark A, Maasing R, Segelberg I [1986]. Silicosis and risk of lung cancer or lung tuberculosis: A cohort study. Environ Res 41:339-350.

Wiles FJ, Hnizdo E [1991]. Relevance of airflow obstruction and mucus hypersecretion to mortality. Resp Med 85(1):27-35.

WHO [1977]. Manual of the international statistical classification of diseases, injuries, and causes of death, based on the recommendations of the Ninth Revision Conference, 1975. Geneva, Switzerland: World Health Organization.

WHO [1986]. Recommended health-based limits in occupational exposure to selected mineral dusts (silica, coal). Geneva, Switzerland: World Health Organization, Technical Report Series 734.

WHO [1993]. WHO calls for medical surveillance of workers exposed to mineral dusts. Geneva, Switzerland: World Health Organization, Press release WHO/73, September 23.

WHO [1996]. Groups at risk: WHO report on the tuberculosis epidemic, 1996. Geneva, Switzerland: World Health Organization.

Wiecek E [1988]. Experimental silicosis: The effect of the actual structure of quartz and cristobalite on the fibrosing action of these minerals. Med Prac 39(2):149152.

Wiles FJ, Faure MH [1977]. Chronic obstructive lung disease in gold miners. In: Walton WH, ed. Inhaled particles, IV, Part 2. Oxford, England: Pergamon Press, pp. 727-735.
Wilke RA [1997]. Occupational exposure to silica and end-stage renal disease [letter to the editor]. J Am Med Assoc 278(7):546-547.

Wilke RA, Salisbury S, Abdel-Rahman E, Brazy PC [1996]. Case report. Lupus-like autoimmune disease associated with silicosis. Nephrol Dial Transplant 11: $1835-1838$.

Wilt JL, Parker JE, Banks DE [1998]. The diagnosis of pneumoconiosis and novel therapies. In: Banks DE, Parker JE, eds. Occupational lung disease. London: Chapman \& Hall, pp. 119-138.

Xu X, Dockery DW, Ware JH, Speizer FE, Ferris BG [1992]. Effects of cigarette smoking on rate of loss of pulmonary function in adults: A longitudinal assessment. Am Rev Respir Dis 146:1345-1348.

Xu Z, Pan G-W, Liu L-M, Brown LM, Gaun D-X, Xiu Q, Sheng J-H, Stone BJ, Dosemeci M, Fraumeni JF Jr., Blot WJ [1996]. Cancer risks among iron and steel workers in Anshan, China: Part I. Proportional mortality ratio analysis. Am J Ind Med 30:1-6.

Yamamoto T, Furuse Y, Katayama I, Nishioka K [1994]. Nodular scleroderma in a worker using a silica-containing abrasive. J Dermatol 21(10):751-754.

Yanez Diaz S, Moran M, Unamuno P, Armijo M [1992]. Silica and trichloroethylene-induced progressive systemic sclerosis. Dermatology 184:98-102.

Zahm SH, Blair A [1993]. Cancer among migrant and seasonal farmworkers: An epidemiologic review and research agenda. Am J Ind Med 24:753-766.

Zheng W, Shu XO, Ji BT, Gao YT [1996]. Diet and other risk factors for cancer of the salivary glands: A population-based case-control study. Int J Cancer 67:194-198.

Zhong B, Whong W, Ong T [1997]. Detection of mineral-dust-induced DNA damage in two mammalian cell lines using the alkaline single cell gel/comet assay. Mutat Res 393:181-187.

Ziegler V, Haustein U-F [1992]. Systemic scleroderma - a silica induced occupational disease? Epidemiological, clinical, immunological, mineralogical, animal and cell culture investigations. Dermatol Monatsschr 178:34-43.

Ziskind M, Jones RN, Weill H [1976]. Silicosis. Am Rev Respir Dis 113:643-665. 
Zoubek V, Kordac V [1986]. Free silicon dioxide as a factor in symptomatic manifestation of hepatic porphyria. Prakt Lek 66:492-493.

Zumwalde RD, Ludwig HR, Dement JM [1981]. Industrial hygiene report: Homestake Mining Company, Lead,
South Dakota. Cincinnati, OH: U.S. Department of Health and Human Services, Public Health Service, Centers for Disease Control, National Institute for Occupational Safety and Health, Division of Surveillance, Hazard Evaluations and Field Studies, Industrial Hygiene Section, Industrywide Studies Branch. 


\section{Appendix Occupational Exposure Limits}

Table A-1. U.S. guidelines and limits for occupational exposure to crystalline silica

\begin{tabular}{|c|c|c|}
\hline Reference & Substance & Guideline or limit $\left(\mathbf{m g} / \mathbf{m}^{3}\right)$ \\
\hline NIOSH [1974] & $\begin{array}{l}\text { Crystalline silica: }{ }^{*} \text { quartz, cristobalite, and } \\
\text { tridymite as respirable dust }\end{array}$ & $\begin{array}{l}\mathrm{REL}^{\dagger}=0.05 \text { (for up to a } 10-\mathrm{hr} \text { workday } \\
\text { during a } 40-\mathrm{hr} \text { workweek) }\end{array}$ \\
\hline \multirow{3}{*}{$\begin{array}{l}\text { OSHA [29 CFR } \\
1910.1000-\text { Table Z-3] }\end{array}$} & Respirable crystalline silica, quartz & $\mathrm{PEL}=10 \div \%$ quartz $+2(8-\mathrm{hr}$ TWA $)$ \\
\hline & Respirable crystalline silica, cristobalite & $\begin{array}{l}\mathrm{PEL}=\text { half of the value calculated from } \\
\text { the formula for quartz }\end{array}$ \\
\hline & Respirable crystalline silica, tridymite & $\begin{array}{l}\mathrm{PEL}=\text { half of the value calculated from } \\
\text { the formula for quartz }\end{array}$ \\
\hline \multirow[t]{2}{*}{$\begin{array}{l}\text { MSHA [30 CFR 56, } 57 \text {, } \\
\quad 70,71]\end{array}$} & $\begin{array}{l}\text { Respirable quartz in underground and surface } \\
\text { metal and nonmetal mines }\end{array}$ & $\mathrm{PEL}=10 \div \%$ quartz $+2(8-\mathrm{hr}$ TWA $)$ \\
\hline & $\begin{array}{l}\text { Respirable crystalline silica present in } \\
\text { concentrations }>5 \% \text { in surface and } \\
\text { underground coal mines }\end{array}$ & $\operatorname{RDS}^{\dagger}=10 \div \%$ quartz $(8-\mathrm{hr}$ TWA $)$ \\
\hline \multirow[t]{3}{*}{ ACGIH [2001] } & Respirable crystalline silica, quartz & $\mathrm{TLV}=0.05(8-\mathrm{hr}$ TWA $)$ \\
\hline & Respirable crystalline silica, cristobalite & $\mathrm{TLV}=0.05(8-\mathrm{hr}$ TWA $)$ \\
\hline & Respirable crystalline silica, tridymite & $\mathrm{TLV}=0.05$ (8-hr TWA $)$ \\
\hline
\end{tabular}

Adapted from Hearl [1996].

*Identified by NIOSH as a potential occupational carcinogen [54 Fed Reg. 2521 (1989)].

${ }^{\dagger}$ Abbreviations: REL $=$ recommended exposure limit; PEL $=$ permissible exposure limit;

$\mathrm{RDS}=$ respirable dust standard; TLV = threshold limit value; TWA = time-weighted average. 